ADÉLIA CRISTINA PESSOA ARAÚJO

\title{
IMPORTÂNCIA DA ANÁLISE DE RESÍDUOS DE PRAGUICIDAS PARA AÇÕES DE SAÚDE PÚBLICA: ESTUDO DA CULTURA DO TOMATE DO ESTADO DE PERNAMBUCO
}

Tese apresentada à Faculdade de Saúde Públ da Universidade de São Paulo, para obtenção Grau de Doutor em Saúde Pública, com área concentração em Saúde Ambiental.

Orientador: Prof. Dr. Diogo Pupo Nogueira

Dr

339

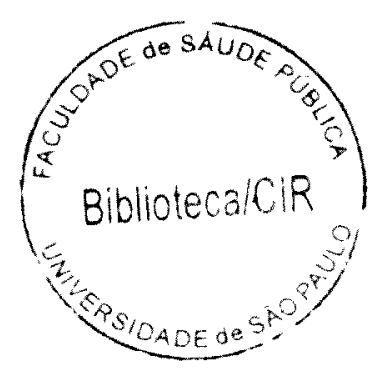

São Paulo, 1998 
Para

Sergio, Andely,

e

minha querida turma miúda, Filipe, Henrique, Livia, Bren Leonardo, Lais, Túlio, Gustavo, Érica e Natália,

com o meu carinho. 
Ao Sergio,

pelos ensinamentos e orientação ao longo da minha vida profissior apoio incondicional em todos os momentos e gratificante convivênc

- meu especial agradecimento 


\section{AGRADECIMENTOS}

Às diretorias do Instituto Tecnológico do Estado de Pernambuco - ITEP, por proporcionar meios para o desenvolvimento do meu trabalho profissional e, particularmente, deste trabalho.

Ao Conselho Nacional de Pesquisa e Desenvolvimento - CNPq. Fundação de Amparo à Ciência e Tecnologia de Pernambuco - FACEPE, Banco do Nordeste do Brasil - BNB e Fundação Banco do Brasil - FBB pelo apoio financeiro.

Ao Professor Diogo Pupo Nogueira, pelo apoio e confiança no meu trabalho.

À colega de trabalho Danuza Leal Telles, pela ajuda, amizade e companheirismo sempre presentes, e por assumir prontamente a responsabilidade por minhas atribuições funcionais nos momentos em que me afastei para realizar este trabalho.

À Lia Giraldo da Silva Augusto, do CPqAM / NESC / FIOCRUZ, pelas valiosas sugestões, discussões e orientação nas questões relacionadas com a saúde do trabalhador, o que tornou possivel a ampliação da proposta inicial do trabalho.

À Nestlé Industrial e Comercial Ltda. / Departamento de Contaminantes e Autenticidade, nas pessoas de Oswaldo Marmo, Jalba Miniussi e Rosângela Gorni, pela carinhosa acolhida para treinamentos, orientação técnica e doações de padrões analíticos e de outros consumiveis de laboratório.

Aos bolsistas de iniciação cientifica e estagiários do Laboratório de Toxicologia / ITEP, em especial Luciana Leite de Andrade Lima, pela prestimosa colaboração técnica. 
Aos colegas das Secretarias Estaduais de Saúde e Agricultura, Distrito de Irrigação Projeto Senador Nilo Coelho, FUNDACENTRO - PE, Delegacia Regional do Trabalho - PE, EMBRAPA - CPATSA e EMBRAPA - CNPMA, pela colaboração em diferentes etapas deste trabalho.

À Stazione sperimentale per l'industria delle conserve alimentari in Parma, pelo estágio e orientação no desenvolvimento de métodos analíticos.

Ao Geraldo Eugênio França, da Empresa Pernambucana de Pesquisa Agropecuária - IPA, pelo fornecimento de literatura científica e proveitosas sugestões relacionadas com a área agronômica.

À Lúcia Carvalheira Cunha, da FUNDAJ, pela colaboração na localização e obtenção de livros e artigos, e a Maria Lúcia Ferraz, da FSP / USP, pela normalização das referências bibliográficas.

À Ana Regina L.U. de Moura, da Diretoria de Recursos Hídricos / SECTMA, Gilvani Holanda e Fernando M.F. Gomes, pelo tratamento digital das imagens de satélite LANDSAT-TM, formatação e computação gráfica.

À amiga de sempre Myriam Clara Salvadori, pelos momentos agradáveis nas minhas estadas em São Paulo e incentivos constantes, sem os quais a realização deste trabalho teria sido bem mais difícil.

A todos que, de alguma forma, contribuiram para a melhoria das condições e da organização deste trabalho. 


\section{INDICE}

página

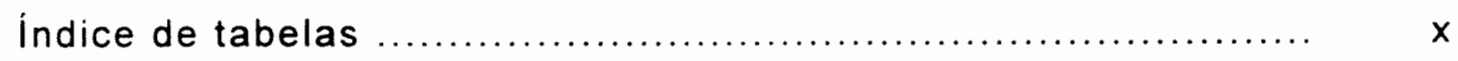

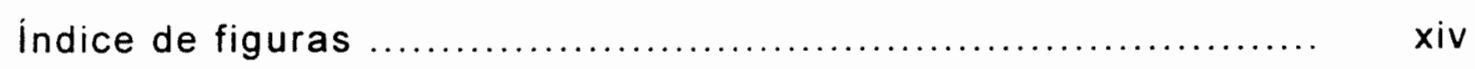

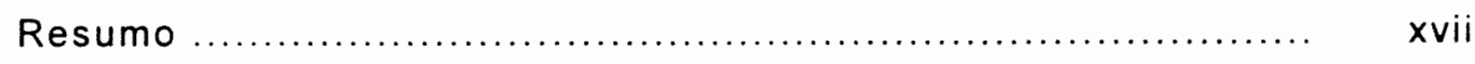

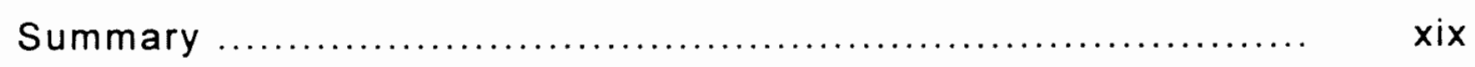

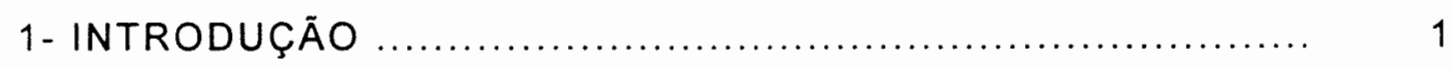

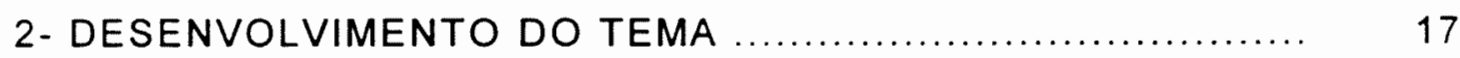

2.1. A cultura de tomate ................................. 21

2.1.1. Aspectos fitossanitários do tomateiro ............ 26

2.1.2. O uso de praguicidas na cultura do tomate ....... 28

2.1.3. Cultivos alternativos ......................... 33

2.2. A cultura de tomate no Estado de Pernambuco .......... 36

2.2.1. Caracterização das regiōes de maior produção de tomate no Estado ............................. 38

2.3. A situação dos praguicidas em Pernambuco .............. 52

2.4. Inseticidas organofosforados, inseticidas organoclorados e fungicidas ditiocarbamatos ....................... 65

2.4.1. Inseticidas organofosforados ................... 65

2.4.2. Inseticidas organoclorados ..................... 68

2.4.3. Fungicidas ditiocarbamatos .................... 72

2.4.3.1. Os etilenobisditiocarbamatos (EBDCs) e etilenotiuréia (ETU) $\ldots \ldots \ldots \ldots \ldots \ldots \ldots \ldots \ldots \ldots \ldots \ldots \ldots$

2.5. Considerações gerais sobre amostragem para análise de residuos de praguicidas 
INDICE (continuação)

página

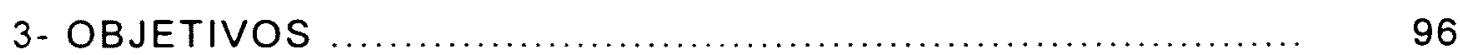

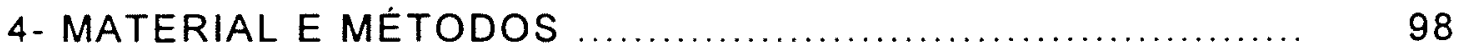

4.1. Definição da estratégia adotada para efeito de amostragem

4.1.1. Projeto Senador Nilo Coelho - tomate industrial

4.1.2. Municipio de Camocim de São Félix - tomate de mesa

4.2. Procedimento para coleta das amostras no campo selecionado

4.3. Classes de praguicidas selecionadas para investigação analítica

4.4. Avaliação dos tipos de praguicidas utilizados no Estado de Pernambuco

4.5. Levantamento de dados sócio-ambientais e de morbidade referida em trabalhadores envolvidos na cultura do tomate

4.6. Métodos analiticos

4.6.1. Cuidados e procedimentos especiais durante as análises de residuos de praguicidas

4.6.2. Método proposto para análise de inseticidas organoclorados em amostras de tomate 
INDICE (continuação)

página

4.6.3. Método proposto para análise de inseticidas organofosforados em amostras de tomate

4.6.4. Método proposto para análise de metamidofós em amostras de tomate

4.6.5. Método proposto para análise de etilenotiuréia (ETU) em amostras de tomate

4.6.6. Validação dos métodos propostos

4.6.6.1. Especificidade

4.6.6.2. Preparação das curvas de calibração ..

4.6.6.3. Parâmetros de confiança dos métodos

5- RESULTADOS

5.1. Avaliação dos tipos de praguicidas utilizados no Estado de Pernambuco

5.1.1. Tipos de praguicidas empregados nas safras de tomate estudadas, segundo informações dos produtores

5.2. Levantamento de dados sócio-ambientais e de morbidade referida em trabalhadores envolvidos na cultura do tomate

5.2.1. Tomate industrial - Projeto Senador Nilo Coelho

5.2.2. Tomate de mesa - Camocim de São Félix 
INDICE (continuação)

página

5.3. Validação dos métodos analíticos utilizados

5.4. Análise de resíduos de praguicidas nas amostras de tomate selecionadas para estudo

6 - DISCUSSÃO

7 - CONCLUSÕES

8 - REFERENNCIAS BIBLIOGRÁFICAS

Anexo I - Imagem digitalizada do perimetro irrigado do Vale do São Francisco, obtida por satélite LANDSATTM

Anexo II - Imagem digitalizada do Municipio de Camocim de São Félix, obtida por satélite LANDSAT-TM

Anexo III - Questionário aplicado em produtores de tomate industrial do Projeto Senador Nilo Coelho

Anexo IV - Questionário aplicado em produtores de tomate de mesa do Município de Camocim de São Félix. 


\section{ÍNDICE DE TABELAS}

página

Tabela 1 Divisão regional de Pernambuco: mesorregiōes e microregiões geográficas e municipios das duas regiões de interesse para este trabalho

Tabela 2 Consumo de produtos derivados do tomate no Brasil, em 1.000 toneladas

Tabela 3 Desenvolvimento da produção de tomate nos principais paises produtores da América do Sul .. 24

Tabela 4 Produção de tomate no Brasil, por regiões

Tabela 5 Limites máximos de residuos (LMR) de praguicidas estabelecidos para o comércio intraregional do Mercosul

Tabela 6 Valores brutos da produção agricola do Estado de Pernambuco, safra 1996

Tabela 7 Principais áreas de concentração populacional de Camocim de São Félix

Tabela 8 Principais trabalhos publicados no pais, referentes ao monitoramento, controle ou avaliação de residuos de praguicidas em alimentos

Tabela 9 Niveis de não efeito (NOEL) e ingestão diária aceitável (IDA) estabelecidos para alguns fungicidas ditiocarbamatos

Tabela 10 Principais trabalhos analíticos, citados na literatura, relativos à detecção de ETU

Tabela 11 Lotes do Projeto Senador Nilo Coelho com plantação de tomate industrial sorteados para estudo, segundo época de plantio e empresa contratada

Tabela 12 Comercialização de tomate pela CEAGEPE, segundo quantidade fornecida por municipios pernambucanos, em toneladas, durante 6 anos... 
ÍNDICE DE TABELAS (continuação)

página

Tabela 13 Propriedades de Camocim de São Félix inicialmente selecionadas para estudo

Tabela 14 Identificação dos pontos de coleta de tomate em Camocim de São Félix para a análise de residuos de praguicidas, com as respectivas áreas cultivadas, data de coleta da amostra para análise e datas de plantio e colheita

Tabela 15 Distribuição das amostras de tomate coletadas em Camocim de São Félix para análise de praguicidas, em relação às propriedades e áreas cultivadas

Tabela 16 Concentração das soluções preparadas para a obtenção das curvas de calibração de 18 padrões de inseticidas organoclorados, por ordem de eluição nas condições cromatográficas estabelecidas

Tabela 17 Concentração das soluções preparadas para a obtenção das curvas de calibração de 3 padrões de endosulfan, por ordem de eluição nas condiçōes cromatográficas estabelecidas

Tabela 18 Concentração das soluções preparadas para a obtenção das curvas de calibração de 9 padrões de inseticidas organofosforados, por ordem de eluição nas condições cromatográficas estabelecidas

Tabela 19 Distribuição dos praguicidas, por grupos, segundo a divisão territorial do Estado e as principais culturas praticadas

Tabela 20 Distribuição dos praguicidas de origem quimica empregados na cultura de tomate industrial do perímetro irrigado do Projeto Senador Nilo Coelho 
ÍNDICE DE TABELAS (continuação)

página

Tabela 21 Produtos mais citados no perimetro irrigado do Projeto Senador Nilo Coelho, com os respectivos princípios ativos em parênteses e sua indicação de uso

Tabela 22 Praguicidas utilizados na safra de tomate de 1996 do Projeto Senador Nilo Coelho, segundo informações fornecidas pelos produtores através de questionário

Tabela 23 Praguicidas utilizados na safra de tomate de 1996/97 do Município de Camocim de São Félix, segundo informações fornecidas pelos produtores, através de questionário

Tabela 24 Parâmetros de confiança do método multiresiduo proposto para a determinação de inseticidas organoclorados em tomate

Tabela 25 Parâmetros de confiança dos métodos multiresiduos e específicos propostos para determinação de inseticidas organofosforados e ETU em tomate

Tabela 26 Resultados da análise de residuos de inseticidas organoclorados e organofosforados das 27 amostras de tomate para indústria sorteadas no Projeto Senador Nilo Coelho, segundo a época de plantio e empresa contratada

Tabela 27 Resultados da análise de resíduos de ETU das 27 amostras de tomate para indústria sorteadas no Projeto Senador Nilo Coelho, segundo a época de plantio e empresa contratada

Tabela 28 Resultados da análise de residuos de inseticidas organoclorados e organofosforados das 32 amostras de tomate de mesa selecionadas no Municipio de Camocim de São Félix 
INDICE DE TABELAS (continuaçāo)

página

Tabela 29 Resultados da análise de residuos de ETU das 32 amostras de tomate de mesa selecionadas no Municipio de Camocim de São Félix ................ 162 


\section{ÍNDICE DE FIGURAS}

página

Figura 1 Divisão geográfica do Estado de Pernambuco em 5 mesorregiões com identificação dos dois municipios estudados

Figura 2 Preparação da mistura de praguicidas para aplicação na cultura de tomate do Município de Camocim de São Félix

Figura 3 Aplicação de praguicidas no Município de Camocim de São Félix

Figura 4 Possivel mecanismo oxidativo de degradação dos EBDCs (1) e fotooxidação da ETU (2)

Figura 5 Esquema utilizado para a coleta de tomate em cada campo selecionado

Figura 6 Fluxograma do procedimento analítico usado na determinação de inseticidas organoclorados e organofosforados em amostras de tomate

Figura 7 Fluxograma do procedimento analitico usado na determinação de metamidofós em amostras de tomate

Figura 8 Fluxograma do procedimento analítico usado na determinação de ETU em amostras de tomate ......

Figura 9 Cromatograma de tomate "branco" enriquecido com 18 inseticidas organoclorados com concentrações entre 2,1 a $21,2 \mu \mathrm{g} / \mathrm{kg}$ e seus respectivos tempos de retenção em minutos

Figura 10 Cromatograma de tomate "branco" enriquecido com endosulfan ( $\alpha, \beta$ e sulfato $)$ com concentrações entre 4,0 a $6,1 \mu \mathrm{g} / \mathrm{kg}$ e seus respectivos tempos de retenção em minutos

Figura 11 Cromatograma de tomate "branco" enriquecido com 9 inseticidas organofosforados com concentrações entre 0,02 a $0,1 \mathrm{mg} / \mathrm{kg}$ e seus respectivos tempos de retenção em minutos 
INDICE DE FIGURAS (continuação)

página

Figura 12 Cromatograma de tomate "branco" enriquecido com $0,06 \mathrm{mg} / \mathrm{kg}$ de metamidofós e seu respectivo tempo de retenção em minutos

Figura 13 Cromatograma de tomate "branco" enriquecido com $30 \mu \mathrm{g} / \mathrm{kg}$ de ETU e seu respectivo tempo de retenção em minutos

Figura 14 Cromatograma de tomate "branco" enriquecido com ETU e PTU, obtido por cromatografia a liquido e detector eletroquímico

Figura 15 Representação gráfica da curva de calibração obtida para a faixa de concentração de 1,24 a $9,96 \mathrm{ng} / \mathrm{mL}$ de $\alpha-\mathrm{HCH}$

Figura 16 Representação gráfica da curva de calibração obtida para a faixa de concentração de 2,5 a 14,9 $\mathrm{ng} / \mathrm{mL}$ de $\alpha$ - endosulfan

Figura 17 Representação gráfica da curva de calibração obtida para a faixa de concentração de 0,012 a $0,046 \mu \mathrm{g} / \mathrm{mL}$ de diclorvós

Figura 18 Representação gráfica da curva de calibração obtida para a faixa de concentração de 0,16 a 1,6 $\mu \mathrm{g} / \mathrm{mL}$ de metamidofós

Figura 19 Representação gráfica da curva de calibração obtida para a faixa de concentração de 0,025 a $0,2 \mu \mathrm{g} / \mathrm{mL}$ de ETU

Figuras Descarte de embalagens vazias de praguicidas $20 a$ e 20 b após o uso em culturas de tomate do Município de Camocim de São Félix

Figura 21 Descarte de embalagens vazias de praguicidas após o uso em cultura de tomate do Municipio de Camocim de São Félix, próximo ao reservatório de água 
ÍNDICE DE FIGURAS (continuação)

página

Figura 22 Filhos de produtores de tomate do Municipio de Camocim de São Félix ingerindo o fruto retirado diretamente do tomateiro......................... 169 


\section{RESUMO}

A presença de resíduos de praguicidas em alimentos, somada à contaminação da água, oferece risco para a população em geral e representa, sem dúvida, um grande problema de saúde pública no Brasil. A livre disponibilidade dos praguicidas, a falta de levantamentos de dados que permitam conhecer qual a ingestão diária de seus resíduos nos diferentes centros populacionais e de uma efetiva preocupação por parte das autoridades de saúde pública colaboram significativamente para a ocorrência de freqüentes acidentes e tragédias no campo e na cidade.

O primeiro passo para o desenvolvimento deste trabalho foi capacitar um órgão da rede estadual com uma estrutura laboratorial para auxiliar programas de controle e monitoramento da produção agrícola regional, do meio ambiente e de vigilância à saúde, para fazer frente ao problemas decorrentes do uso indiscriminado dos praguicidas.

Foram implantados e validados um método multi-residuos para a análise de inseticidas organoclorados e organofosforados e métodos específicos para a detecção de residuos de metamidofós e etilenotiuréia (ETU) em tomates.

A produção de tomate do Estado de Pernambuco foi escolhida para a avaliação dos problemas de saúde da população e para o meio ambiente provocados pelo uso de praguicidas pelas seguintes razões: (1) o Estado é o segundo maior produtor deste fruto no pais; (2) essa cultura, no modelo dominante de produção, demanda uso intensivo de praguicidas e possui um ciclo curto de produção; (3) o tomate está enraizado no hábito alimentar da população em geral. 
Foram selecionadas duas regiōes de produção do Estado, com o objetivo de comparar a agricultura modernizada, praticada nos perímetros irrigados e destinadas à produção industrial, com a agricultura tradicional, responsável por uma grande parcela do abastecimento da regiāo metropolitana de Recife.

Foram utilizados todos os dados disponiveis sobre os tipos de praguicidas empregados no Estado de Pernambuco com o objetivo de avaliar se o uso desses produtos em cada mesorregião é coerente com a produção agrícola existente.

A aplicação de questionários foi o instrumento utilizado para a obtenção de informações sócio-ambientais e de morbidade referida em trabalhadores rurais envolvidos com a cultura de tomate das regiōes estudadas.

Três amostras da produção de tomate industrial $(11,1 \%)$ estavam impróprias para consumo, em virtude dos niveis de metamidofós encontrados. A situação da produção de tomate de mesa foi mais grave, visto que $53,1 \%$ das amostras de tomate $(n=17)$ violaram o estabelecido pela nossa legislação, com niveis não permitidos para os inseticidas organofosforado metamidofós e o organoclorado endosulfan.

Os resultados obtidos nas duas regiōes estudadas mostraram que a produção orientada da agricultura resulta na produção de tomate com melhor qualidade, no que se refere a residuos de praguicidas. Porém, ficou constatado que as duas regiōes estudadas, indiscriminadamente. carecem de ações que visem à proteção da saúde dos trabalhadores rurais que lidam com os praguicidas e de medidas contra os danos para ao meio ambiente, que se encontra gravemente comprometido. 


\section{SUMMARY}

In addition to water contamination, the presence of pesticide residues in food is a risk to the population as a whole, which undoubtedly constitutes a severe public health problem in Brazil. The uncontrolled availability of pesticides, the lack of information and data on daily ingestion of these residues in food, and the lack of effective concern on the part of the public health authorities greatly contribute to the frequent occurrence of accidents and tragedies in both rural and urban areas

The first step in the development of this study was to provide a state institution with laboratory facilities to aid programs for monitoring and controlling regional agricultural production as well as environment and health surveillance, in order to address the problem posed by uncontrolled use of pesticides.

A multi-residue method was validated to quantify organochlorine and organophosphorous insecticides as well as selective methods for detection of residues of methamidophos and ethylenathiourea (ETU).

To evaluate problems resulting from the use of pesticides, which affect human health and the environment, tomato production in the state of Pernambuco was chosen for the following reasons: 1) Pernambuco is the second largest producer of tomatoes in the country; 2) tomato production, which has a short cycle, is characterized in the present development model, by intensive use of pesticides; and 3 ) tomato consumption is widely-spread and deeply rooted in the eating habits of the population.

To compare modern agricultural methods employed in irrigated areas designated for industrial production with traditional agriculture largely 
responsible for supplying the Recife metropolitan area, two production regions of the state were selected.

All existing data on types of pesticides utilized in Pernambuco was considered in the evaluation of the use of these products on agricultural produce.

Questionnaires were applied to obtain socio-environmental information as well as morbidity rates and data on rural workers involved in tomato production in regions under study.

Three samples from industrial production $(11,1 \%)$ were considered improper for human ingestion because the metamidophos level was above the maximum residue limit. Fresh tomatoes for direct consumer use tested far worse: $53,1 \%$ of the samples $(n=17)$ presented levels of metamidophos and endosulfan higher than those acceptable by consumer protection legislation.

The results obtained in the two regions studied show that the modernization of agricultural methods does result in the production of better quality tomatoes in regard to lower pesticide residue. However, they also demonstrate that both regions lack effective policies to not only protect the health of rural workers who deal with pesticides, but also to protect the environment which has already been severely damaged. 
1 - INTRODUÇÃO 
Os praguicidas têm seu uso associado a tempos remotos, desde a Antigüidade Clássica, quando consistiam de misturas de produtos quimicos brutos ou agentes botânicos derivados de plantas. Alguns deles, como a mistura Bordeaux, complexo de sulfato de cobre e cal hidratada, ainda são utilizados. As escritas dos gregos e romanos mencionavam o uso de certos produtos quimicos, como o arsênico e o enxofre, para o controle de insetos nos primórdios da agricultura. Porém, com exceção das pragas de gafanhotos que têm devastado áreas cultivadas e naturais por milênios, as pragas agricolas só se tornaram problema econômico sério nos dois últimos séculos, após a revolução industrial (Zambrone, 1986; Andrade, 1995)

No inicio do século 20 , vários compostos inorgânicos metálicos à base de cobre, arsênio, chumbo, mercúrio, cádmio, flúor e antimônio foram preparados comercialmente e empregados contra um grande número de pragas. Porém, devido à limitada eficácia e à tendência de acumulação a niveis tóxicos no solo associadas a esses produtos, surgiram os organometálicos no começo dos anos 20 , sendo amplamente empregados como fungicidas. Em 1940, após a comprovação da extraordinária propriedade inseticida do primeiro composto orgânico sintético, o DDT (diclorodifeniltricloroetano), também empregado no combate a mosquitos transmissores de doenças, o interesse foi direcionado para os compostos orgânicos puros, o que estimulou a sintese de uma série de outros organoclorados. Durante a Segunda Guerra Mundial, surgiu o composto organofosforado denominado Schradan, destinado a ser usado como gás de guerra, sendo, posteriormente, comercializado como inseticida agricola com o nome de OMPA. Simultaneamente ao desenvolvimento dos 
inseticidas e fungicidas, surgiu o interesse pela sintese dos herbicidas, e a produção e a aplicação de novos produtos organoclorados e herbicidas foram elevadas entre 1940 e 1980 (Zambrone, 1986; Pimentel e col., 1993).

Desde 1945. o uso de praguicidas sintéticos é prática conhecida nos Estados Unidos. Foi, no entanto, a partir dos anos 50 que a comercialização desses produtos, a nivel mundial, teve seu inicio de forma vertiginosa. No Brasil, o primeiro produto introduzido foi o hexaclorociclohexano (denominado BHC), em 1946, para uso contra gafanhotos, sendo aplicado, posteriormente, em culturas de café e algodão. Em seguida, vieram o DDT, paration e toxafeno (Dinham, 1993).

Muitos paises da Ásia, África e América Central e do Sul conseguiram erradicar a malária com a aplicação do DDT, através de um programa da Organizaçāo Mundial da Saúde e da Agência Americana para - Desenvolvimento Internacional, em colaboraçāo com os governos locais. Os praguicidas representam, ainda hoje, armas disponiveis para o combate à malária, doença de Chagas e esquistossomose (Bull e Hathaway, 1986; Zambrone, 1986; Almeida e Soares, 1992).

A publicação, no inicio da década de 60 , do livro Silent Spring, de Rachel Carson, com duras criticas ao uso indiscriminado dos praguicidas e alerta sobre os possiveis impactos para o meio ambiente e para a própria agricultura, contribuiu para estimular medidas de proteção ambiental em alguns paises. Apesar desse fato, o seu uso foi bastante estimulado, atingindo o ápice na década de 70 , quando ocorreram modificaçōes na política agricola mundial (Rüegg e col., 1991; Almeida e Soares, 1992).

Essa mudanca implicou, tanto para o Brasil como para os demais 
paises da América Latina, um processo de substituição das práticas agricolas tradicionais pela monocultura de grandes extensões. Tal modelo agricola, apoiado pela premissa da "Revolução Verde", fomentou o uso de insumos mecânicos e químicos, principalmente dos produtos destinados ao controle das pragas (Bull e Hathaway, 1986; Rüegg e col., 1991; Almeida e Soares, 1992; Dinham, 1993).

A revolução verde resultou na plantação de áreas relativamente grandes com uma única variedade de uma só cultura, provavelmente menos resistente ao ataque de praga do que as fortes variedades tradicionais substituidas. O uso de quantidades relativamente grandes de fertilizantes, outra característica dessa politica, produzia um crescimento exuberante, com possibilidade de hospedar uma maior população de pragas (Bull e Hathaway, 1986).

Em 1972, o Banco do Brasil, seguindo o Plano Nacional de Desenvolvimento, iniciou o crédito rural, do qual $15 \%$ eram destinados à "tecnologia moderna", isto é, aos praguicidas, e o Conselho Monetário Nacional chegou a promover a isenção total de encargos bancários para as operações de crédito rural destinadas à aquisição de insumos modernos (Ferrari, 1985; Rüegg e col., 1991; Dinham, 1993; Andrade, 1995).

O financiamento bancário obrigava os agricultores a adquirir insumos e equipamentos, muitas vezes desnecessários, e essa obrigatoriedade, somada à intensa propaganda dos fabricantes, determinou um enorme incremento e a disseminação da utilização de praguicidas no pais. A politica de estímulo do crédito agricola, dirigida à obtenção de divisas e ao desenvolvimento industrial, trouxe um grande impulso a várias culturas, principalmente às destinadas à exportação 
(Ferrari, 1985; Rüegg e col., 1991).

O governo brasileiro chegou a implantar, em 1975. O Plano Nacional de Defensivos Agricolas (PNDA), para estimular o consumo e a produção nacionais de praguicidas, não obstante a defasagem da legislação, datada de 1934 (Andrade, 1995). As indústrias locais conseguiam isenção de Imposto de Circulação de Mercadorias (ICM) e Imposto sobre Produtos Industrializados (IPI) para a aquisição de produtos, máquinas e equipamentos destinados à instalação de novas fábricas e a ampliação das já existentes (Rüegg e col., 1991; Andrade, 1995).

Em um prazo relativamente curto, tornou-se evidente que as novas práticas agricolas trariam conseqüências nefastas tanto para a saúde humana como para o meio ambiente. A substituição da agricultura de subsistência pela monocultura significou sérias alteraçōes nos ecossistemas naturais, propiciando o aumento de determinados tipos de pragas, com conseqüente dependência do uso de praguicidas. O uso desses produtos de forma indiscriminada eliminava, também, os inimigos naturais das pragas, o que as tornava importantes, por não mais existirem seus predadores naturais (Ferrari, 1985; Rüegg e col., 1991; Dinham, 1993).

Por outro lado, o crescimento do consumo de praguicidas na década de 70 não se fez acompanhar de um avanço proporcional na produção agricola. Assim, quando, na primeira metade dos anos 80 , as possibilidades de crédito diminuiram e observou-se uma redução do consumo de praguicidas, não houve uma alteração significativa da produção agricola, o que sugere que tais perdas se relacionam mais 
diretamente com práticas agricolas e condições climatológicas (Ferrari, 1985: Dinham, 1993).

De fato, a utilização dessas tecnologias acarretou, inicialmente, um aumento na produtividade de grãos por hectare, resultando, entretanto, em um declinio de produção em áreas de cultivo intensivo (Pimentel e col., 1993). Acredita-se que, apesar da crescente utilização de praguicidas na agricultura, cerca de 9.000 espécies de insetos, 50.000 espécies de patógenos de plantas e 8.000 tipos de ervas daninhas sejam responsáveis pela baixa produtividade elou perda de culturas (Ferrari, 1985; Ross e Lembi, 1985; Rüegg e col., 1991).

Em 1991, a venda mundial de praguicidas foi equivalente a US\$ 24 bilhões, o que corresponde a um consumo anual de 2,5 milhōes de toneladas: $93 \%$ desse mercado pertence a 25 grandes companhias, e as 10 maiores, situadas na Europa e E.U.A., ficam com $73 \%$ do total. O Japão, apesar de ter pouca participação no mercado atual, vem apresentando um significativo crescimento em suas vendas (Dinham, 1993).

O custo envolvido para o desenvolvimento de novos praguicidas e a estabilidade do mercado nos paises desenvolvidos direcionaram muitas companhias que desejavam expandir-se para os paises em desenvolvimento, e algumas delas calculam que o Terceiro Mundo dobrará o uso desses produtos nos próximos 10 anos (Dinham, 1993).

Em 1975, o Brasil já era o quarto consumidor mundial de praguicidas, antecedido pelos E.U.A., Japão e França (Naschenveng, 1983). Dados da ANDEF (1995) indicam que o Brasil é considerado um dos maiores mercados de praguicidas do mundo, com venda anual em torno de 
US\$ 1.500 milhões. Em 1996, existiam, no Brasil, 243 ingredientes ativos e 616 marcas comerciais (ANDEF, 1995/1996).

Diferentemente do ocorrido no Brasil, programas de acompanhamento e avaliação do efeito residual dos praguicidas é assunto de preocupação de agências internacionais e americanas há mais de 40 anos. Ainda em 1950, a FAO (Organização das Nações Unidas para a Agricultura e Alimentação), em conjunto com a OMS (Organização Mundial da Saúde), iniciou estudos de aditivos e residuos de praguicidas em alimentos. Com a função de executar o programa conjunto FAO/OMS sobre normas alimentares, em 1962, foi criada a Comissão do Codex Alimentarius. Em 1975, a UNEP (Programa Ambiental das Naçōes Unidas), juntamente com a FAO e OMS, iniciou o Programa de Monitoração para Contaminação de Alimentos, sendo a primeira responsável também pela criação do GEMS, Sistema de Monitoramento Ambiental Mundial. E ainda, com atuação especifica nos Estados Unidos, existem a FDA (Agência Americana de Alimentação e Drogas) e a EPA (Agência de Proteção Ambiental), sendo a última criada especificamente para o meio ambiente (FAO, 1995a). O importante é que todos esses organismos estabelecem prioridades, estando residuos de praguicidas dentre as primeiras preocupações para todos eles e, no entanto, essas açōes resultaram em pouca ou, em alguns casos, nenhuma repercussão para a situação que ocorre internamente no Brasil.

Paralelamente ao grande volume de praguicidas colocados à disposição da agricultura brasileira, não houve uma preocupação em capacitar o homem do campo para a utilização desses produtos nem protegê-lo. o que o fez ficar à margem do programa de desenvolvimento 
econômico. O descompasso entre a velocidade de introdução no mercado desses produtos e a capacidade técnica de prover os meios de segurança para seu uso têm sido um grave problema, até mesmo pela ausência de monitoramento ambiental e de vigilância à saúde.

Agrotóxicos, praguicidas, defensivos agrícolas, pesticidas e até biocidas são denominaçōes dadas a substâncias quimicas, naturais ou sintéticas, destinadas a matar, controlar ou combater de algum modo as pragas, no sentido mais amplo: tudo aquilo que ataca, lesa ou transmite enfermidade às plantas, aos animais e ao homem. Define-se como praga os insetos, carrapatos, aracnideos, roedores, fungos, bactérias, ervas daninhas ou qualquer outra forma de vida animal ou vegetal, danosa à saúde e ao bem-estar do homem, à lavoura, à pecuária e seus produtos e a outras matérias-primas alimentares. Por extensão, incluem-se nessa categoria os agentes desfolhantes, os dessecantes e as substâncias reguladoras do crescimento vegetal (Zambrone, 1986).

Todos os praguicidas são substâncias tóxicas, podendo a sua utilização oferecer ou não risco para o ser humano. A segurança que se pode ter em seu uso está diretamente relacionada com as condições de exposição (Repetto e Baliga, 1996), ou seja, o tempo ou a freqüência de exposição, via de introdução no organismo, dose ou concentração e propriedades físico-quimicas do composto, e a susceptibilidade do individuo exposto ao agente químico.

O principal problema acarretado pelos praguicidas é o seu uso indiscriminado, sem qualquer preocupação com a segurança. Os danos gerais são agravados quando seu uso não é seguido de informações claras sobre o seu emprego e possiveis danos, ou quando tais informações não 
podem ser facilmente absorvidas pelos usuários. As pessoas que têm contato direto com os praguicidas, na fabricação e aplicação dos mesmos, podem correr riscos de intoxicação que, dependendo do produto e dos cuidados seguidos, podem, muitas vezes, ser fatais. Nos alimentos, esses compostos podem permanecer vindos de uma aplicação direta em uma das fases de sua produção, transporte ou armazenamento. Podem, também, ser introduzidos por uma via indireta, é o caso de animais alimentados com ração que contenha vegetais antes tratados com praguicidas ou de rotação das culturas, em que o solo contendo o remanescente de uma aplicação anterior contamina novas produções. A extrema persistência de alguns praguicidas torna-os contaminantes encontrados em ambientes terrestres e aquáticos por muitos anos (Zambrone, 1996; Lara, 1986; Rüegg e col., 1991; Andrade, 1995).

A insuficiência de infra-estrutura laboratorial e, até mesmo, de conhecimento cientifico para se proceder a um controle efetivo pertinente de pragas possibilitou a disseminação de praguicidas pelo meio ambiente, com concentração de residuos na cadeia alimentar. Isso significa que, hoje, praticamente toda a população humana apresenta algum nivel de contaminação por praguicidas (Ferreira, 1993).

Segundo dados da Organização Mundial da Saúde (WHO,1990), os praguicidas são responsáveis por mais de 20.000 mortes não intencionais por ano, a maioria das quais ocorrem no Terceiro Mundo, onde se estima que 25 milhōes de trabalhadores agricolas são intoxicados de forma aguda por ano. Cerca de $70,0 \%$ dos praguicidas produzidos anualmente são consumidos em paises considerados desenvolvidos, no entanto, a maior quantidade de mortes decorrentes da exposição humana a esses agentes 
é observada nos paises em desenvolvimento (Dinham, 1993; PAHO, 1993: Repetto e Baliga, 1996).

As intoxicações agudas de aplicadores de praguicidas no Brasil foram intensificadas e, segundo Rüegg e col. (1991), há ocorrência de um caso de intoxicação aguda em cada 8 trabalhadores agricolas examinados. Estima-se, ainda, que cerca de $2 \%$ da população brasileira é contaminada anualmente por praguicidas e que, para cada caso constatado em hospitais e ambulatórios, deve haver, aproximadamente, 250 vitimas nāo registradas, principalmente pela falta de conhecimentos toxicológicos dos médicos (PAHO, 1993; Garcia, 1996).

No Brasil, são poucas as fontes de informaçōes disponiveis sobre intoxicação por esses produtos e inexistentes em uma boa parte do pais. Segundo Naschenveng (1983), os principais fatores que favorecem a subestimação dos indices de morbidade e mortalidade por praguicidas são: 1. a demora na procura do atendimento médico, o qual ocorre quando já é tarde demais, e 0 individuo morre sem assistência médica, o que dificulta a determinação da causa mortis;

2. a falta de relacionamento dos efeitos da intoxicação com as causas e a falta de fornecimento de informaçōes adequadas ao médico; com freqüência, o paciente apresenta outra doença que, por confusāo de sintomas, é dada como causa da morte;

3. O efeito cumulativo de alguns praguicidas permite que sua ação tóxica só apareça posteriormente, o que dificulta ou mesmo impede que se determine a causa do acidente;

4. por motivos sociais e econômicos, o atestado de óbito é falsificado ou nāo revela toda a verdade: se a intoxicaçāo for classificada como 
acidente de trabalho, poderá representar indenizaçōes e/ou encargos sociais:

5. a dificuldade de se dimensionarem os riscos e os efeitos indiretos para a população consumidora dos produtos agricolas e vizinha às lavouras em virtude de uma aplicação inadequada;

6. falhas nos atestados de óbitos.

A relação entre o uso de praguicidas e seus efeitos nocivos para o homem começou a despertar a atenção de pesquisadores no Brasil no inicio da década de 1950. Os trabalhos de Planet (1950), Rodrigues (1957), Almeida (1959) e Schwartzman (1960) estão entre os primeiros a demonstrar a incidência de intoxicações humanas decorrentes do uso de praguicidas.

As observações registradas por Almeida e Soares (1992), oriundas da cultura do fumo no Municipio de Santa Maria-RS, refletem a condição atual de grande parte da população rural brasileira que lida com os produtos quimicos no campo:

- os praguicidas são considerados indispensáveis para a cultura, mas não existe qualquer tipo de curso de capacitação ou treinamento para os agricultores saberem como manusear esses produtos;

- a armazenagem dos praguicidas é, muitas vezes, improvisada em um compartimento de residência para este fim, que, geralmente, fica perto da cozinha e da circulação dos membros da familia;

- o preparo da calda não tem local especifico, podendo o mesmo ser feito junto do galpão ou na própria lavoura; muitas vezes o produto derrama na mão do trabalhador;

- durante a aplicação não há preocupação com a posição do vento, nem 
com o horário do dia: os equipamentos de aplicação, quando presentes. encontram-se quase sempre danificados; nota-se claramente algum vazamento no bico, na manga, na válvula de sucção, na tampa, o que resulta em um contato direto com o produto; pode-se freqüentemente observar pessoas aplicando agrotóxicos sem cumprir as recomendações sobre a distância e sua indumentária;

- dificilmente os equipamentos de proteção são vistos nas propriedades e mais difícil ainda é ver o fumicultor utilizá-los;

- a higiene pessoal não é levada em consideração pela maioria dos agricultores; para se alimentar ou fumar, raramente lavam as mãos e, no término das atividades, não se preocupam em trocar de roupa ou tomar banho para tirar residuos superficiais de praguicidas;

- a situação é precária no que se refere à alfabetização;

- as embalagens dos praguicidas utilizados são abandonadas no campo ou jogadas nos arroios; se forem resistentes, podem ser utilizadas para outros fins.

O descarte das embalagens vazias de praguicidas, nos moldes hoje praticados pela maioria dos produtores rurais, constitui uma séria ameaça ao meio ambiente. Lançadas no meio ambiente, elas vão causar transtornos nos cursos d'água, lavouras ou onde quer que sejam deixadas. Esse lixo é constituido por material de dificil decomposição, principalmente quando submerso, o que explica o seu acúmulo no meio ambiente durante tantos anos (Branco, 1994).

O impacto sobre o ambiente resulta nos desgastes lentos dos recursos naturais, em alguns casos, irreparáveis. Dentre eles, estão a morte de animais silvestres, insetos úteis para a agricultura, peixes, a 
contaminação das águas e os residuos em alimentos, com implicações diretas para a saúde humana (Rüegg e col. 1991). No início da década de 70, as questões ambientais começaram a receber, em termos mundiais, uma maior atenção. Foi, no entanto, nos anos 80 , a partir do surgimento do conceito de desenvolvimento sustentável, que o crescimento econômico e a qualidade do meio ambiente passaram a ser considerados compativeis e até mesmo complementares (Andrade, 1995).

Considerando a característica agricola do Brasil e os riscos inerentes à atual prática de utilização de praguicidas, pode-se dizer que sāo insignificantes os dados disponiveis referentes ao controle e à avaliação do impacto para o homem e o meio ambiente. Grande parte dos trabalhos publicados sobre contaminação ocupacional, ambiental e de alimentos são ações isoladas de alguns órgãos de controle e institutos tecnológicos elou de pesquisa, os quais, praticamente, restringem-se às regiōes sul e sudeste. A nossa realidade, entretanto, necessita trabalhos de monitoramento com açōes integradas e não pontuais e desvinculadas de qualquer articulação maior.

Os custos sociais e ambientais decorrentes do uso de praguicidas não são internalizados na produção; isso significa que resta ao poder público o dano ambiental e da saúde e o custo com a reparação, a qual, certamente, não tem sido realizada, potencializando o ciclo de crescente destruição dos ecossistemas e de comprometimento da qualidade de vida do ser humano.

Os residuos de praguicidas presentes nas águas e nos alimentos representam as principais fontes de exposição da população em geral. Segundo a Organização Panamericana da Saúde, na América Latina a 
população se expõe a quantidades significativas de praguicidas através de residuos em alimentos (PAHO, 1993). Conforme avaliação de Garcia (1996), "no Brasil há poucos laboratórios e com capacidade limitada para proceder a análises de residuos, poucos técnicos preparados para essa atividade e poucos recursos financeiros para esse fim, e não há trabalhos coordenados de vigilancia sistemática e continua de resíduos".

Apesar do uso bastante disseminado dos praguicidas e da existência de ampla literatura sobre os efeitos tóxicos da exposição aos mesmos, ainda são grandes as dificuldades encontradas para a implantação e o manuseio de laboratórios oficiais capacitados a analisá-los. particularmente a nivel residual. Hoje, apesar de as regiōes Sul e Sudeste do pais possuirem laboratórios adequados, estes são em número insuficiente para atender às necessidades brasileiras, no que se refere à análise de residuos em alimentos, controle de novas formulações lançadas no mercado, avaliação dos efeitos tóxicos provocados em diferentes condições de exposição, e estudos relativos aos impactos para o meio ambiente.

O primeiro passo para o desenvolvimento do presente trabalho foi iniciar a implantação, na rede estadual, de um laboratório e a formação de uma equipe técnica especializada, capacitada para desenvolver análises de residuos de praguicidas e, desta forma, dar suporte a diferentes ações regionais de monitoramento, avaliação e controle do uso de praguicidas. A inexistência no Estado de um laboratório capacitado, as distâncias e os custos envolvidos na utilização de laboratórios dos grandes centros, a demanda regional crescente e as denúncias de eventuais riscos envolvidos justificavam o investimento. 
Assim, através de projetos aprovados por diferentes órgãos de fomento à pesquisa, como Conselho Nacional de Desenvolvimento Cientifico e Tecnológico (CNPq), Fundação de Amparo à Ciência e Tecnologia de Pernambuco (FACEPE), Fundação Banco do Brasil (FBB) e Banco do Nordeste do Brasil (BNB), além de apoio técnico de equipes experientes de outras instituições, em particular da Nestlé Industrial e Comercial Ltda. I Departamento de Contaminantes e Autenticidade (São Paulo, SP), vem sendo possivel, de forma gradual, concretizar essa proposta. Como conseqüência, vários empreendimentos foram realizados, sobretudo no que se refere à compra de equipamentos, à adequação da infra-estrutura laboratorial e aos treinamentos especificos. Aos poucos, essa capacitação tecnológica em um órgão do Estado e uma maior interação com outros órgãos, estaduais ou não, vem favorecendo o desenvolvimento de trabalhos na área de residuos de praguicidas e colaborando no entendimento dos problemas regionais relacionados à contaminação ambiental por praguicidas e suas implicações para o homem, a agricultura e o meio ambiente.

Neste trabalho, foi estudada a presença de residuos de praguicidas em tomates produzidos em duas regiōes do Estado de Pernambuco, por ter a cultura desses frutos grande importância sócio-econômica. No modelo dominante de produção, essa cultura demanda uso intensivo de praguicidas, e o tomate está enraizado no hábito alimentar da população em geral.

Em virtude da diversidade de praguicidas utilizados nas culturas de tomate $e$, sobretudo, da inexistência de informações que pudessem direcionar a análise, um trabalho analitico de avaliação de residuos 
envolvendo diferentes grupos de praguicidas representaria elevado custo e tempo. Por essa razāo, alguns praguicidas foram selecionados, considerando-se a quantidade utilizada, os riscos envolvidos e a disponibilidade laboratorial. Foram estudados, então, alguns inseticidas, organofosforados e organoclorados, e fungicidas da classe dos etilenobisditiocarbamatos (EBDCs), através de um produto de degradação, a etilenotiuréia(ETU). Os organoclorados foram selecionados por existirem suspeitas de utilização indevida; os organofosforados, devido ao grande número de principios ativos registrados para a cultura do tomate; e os EBDCs por serem de amplo uso nessa cultura e representarem um assunto bastante polêmico no que se refere ao risco para a saúde e o meio ambiente, além de não existir um método analitico oficial de boa aceitação para a deteç̧ão de seus residuos em alimentos.

Dessa forma. este trabalho representou um passo importante no sentido de avaliar a real situação de risco de exposição a praguicidas no Estado de Pernambuco, certamente com impacto para a saúde humana. 


\section{2 - DESENVOLVIMENTO DO TEMA}


O Estado de Pernambuco representa cerca de $6 \%$ da área total do nordeste brasileiro, com uma superficie de $98.937 .8 \mathrm{~km}^{2}$. O litoral se estende por apenas $187 \mathrm{~km}$, porém, na direção litoral - oeste, a superficie estadual é de $748 \mathrm{~km}$. Essa forma espacial propicia a existência de sucessivas paisagens geográficas, configuradas em três zonas fisiográficas bem definidas: Litoral/Mata, Agreste e Sertāo (Anuário estatistico de Pernambuco, 1995).

O Agreste, respondendo por $24,7 \%$ da superficie do Estado, constitui uma região de transição entre as situações geográficas da Mata e do Sertāo, refletidas nas condiçōes de umidade e relevo. Os efeitos da altitude e da exposição aos ventos somam-se para produzir algumas faixas e numerosas ilhas de clima úmido, denominadas de brejos. Nos brejos, os solos são profundos, o revestimento florístico primitivo deixa de ser caatinga para ser de mata, os cursos d'água são permanentes, as atividades de lavoura tornam-se exclusivas ou preponderantes e as populaçōes, adensadas (Anuário estatístico de Pernambuco, 1995; Carvalho, 1996).

Ao Sertão cabe a maior parte da extensão territorial de Pernambuco, $63.209,8 \mathrm{~km} 2$, ou seja, $63,9 \%$. É o domínio do semi-árido, onde as cotas pluviais atingem em média $650 \mathrm{~mm}$ anuais, havendo regiōes bem menos dotadas nesse sentido. Uma característica importante das chuvas do Sertão é a sua irregular distribuição ao longo do ano, o que provoca periodicamente o fenômeno da estiagem aguda - as secas. Quanto ao relevo, predominam as superficies pediplanizadas, separadas por elevaçōes muito degradadas, com solos rasos e pedregosos. A rede de 
drenagem é tributária do rio São Francisco, constituída de cursos temporários (Anuário estatístico de Pernambuco, 1995; Carvalho, 1996).

Sem retirar o mérito dessa classificação, pode-se dividir o espaço pernambucano em 5 mesorregiões e 19 microrregiões geográficas, levando-se em consideração os processos sócio-econômicos e as especificidades locais e regionais do sistema produtivo (Silva, 1991; Fundação IBGE, 1994; Carvalho, 1996). As mesorregiões, Sertão Pernambucano, São Francisco Pernambucano, Agreste Pernambucano, Mata Pernambucana e Metropolitana do Recife (Figura 1), subdividem-se em microrregiões, e estas abrigam os municípios, conforme mostra a Tabela 1

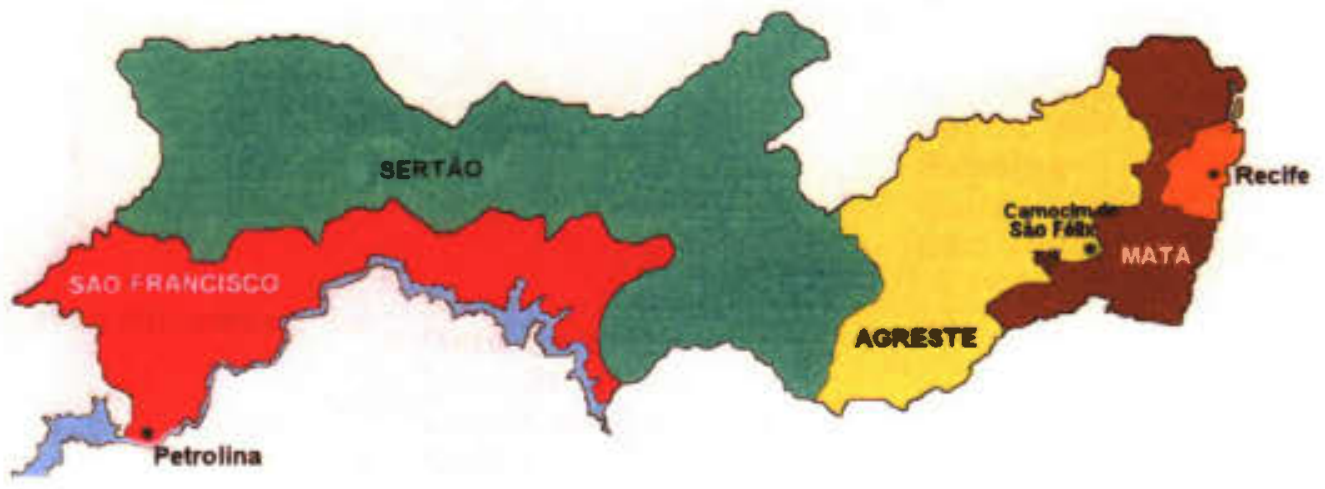

Figura 1 - Divisão geográfica do Estado de Pernambuco em 5 mesorregiōes com identificação dos dois municípios estudados. 
Tabela 1 - Divisão regional de Pernambuco: mesorregiões e microrregiões geográficas e municípios das duas microrregiões de interesse para este trabalho.

\begin{tabular}{|c|c|c|}
\hline mesorregua & microrregla & municiplo \\
\hline Sertão Pernambucano & $\begin{array}{l}\text { Araripina } \\
\text { Pajeú } \\
\text { Salgueiro } \\
\text { Sertão do Moxotó }\end{array}$ & \\
\hline $\begin{array}{l}\text { São Francisco } \\
\text { Pernambucano }\end{array}$ & $\begin{array}{l}\text { Itaparica } \\
\text { Petrolina }\end{array}$ & $\begin{array}{l}\text { Afrånio } \\
\text { Cabrobó } \\
\text { Dormentes } \\
\text { Orocó } \\
\text { Petrolina } \\
\text { Santa Maria da Boa Vista } \\
\text { Terra Nova }\end{array}$ \\
\hline Agreste Pernambucano & $\begin{array}{l}\text { Alto Capibaribe } \\
\text { Médio Capibaribe } \\
\text { Garanhuns } \\
\text { Vale do Ipanema } \\
\text { Vale do Ipojuca } \\
\text { Brejo Pernambucano }\end{array}$ & $\begin{array}{l}\text { Agrestina } \\
\text { Altinho } \\
\text { Barra de Guabiraba } \\
\text { Bonito } \\
\text { Camocim de São Félix } \\
\text { Cupira } \\
\text { lbirajuba } \\
\text { Lagoa dos Gatos } \\
\text { Panelas } \\
\text { Sairé } \\
\text { São Joaquim do Monte }\end{array}$ \\
\hline Mata Pernambucana & $\begin{array}{l}\text { Mata Setentrional } \\
\text { Pernambucana } \\
\text { Vitória de Santo Antão } \\
\text { Mata Meridional } \\
\text { Pernambucana }\end{array}$ & \\
\hline Metropolitana do Recife & $\begin{array}{l}\text { Itamaracá } \\
\text { Recife } \\
\text { Suape } \\
\text { Fernando de Noronha }\end{array}$ & \\
\hline
\end{tabular}

FONTE: Anuário estatístico de Pernambuco, 1995. 
O Estado de Pernambuco apresentou, por ocasião do último censo, uma população de mais de 7 milhōes de pessoas. Segundo dados da Fundação IBGE (1990), apud Carvalho (1996), as pessoas ocupadas e com rendimento mensal até 5 salários minimos perfaziam $78 \%$ do total no Estado; o contingente de renda mensal até um salário minimo representava $32 \%$, dos quais aproximadamente um terço apresentava mensalmente renda de até $1 / 2$ salário minimo e apenas $1,7 \%$ tinham renda superior a 20 salários minimos por mês.

No que se refere à renda estadual, sua participação em relação ao Brasil é da ordem de $3 \%$, o que corresponde a 10,2 bilhões de dólares em 1994, conforme valores estimados pela Fundação IBGE (1994). Segundo o Instituto de Pesquisa Econômica Aplicada (Carvalho, 1996), estima-se que, no Brasil, o número de pessoas indigentes e submetidas à fome è de 32 milhōes, dos quais $54 \%$ estão no Nordeste e $7 \%$ em Pernambuco. Em Pernambuco, esse valor corresponde a $32 \%$ da população estadual, localizada mais expressivamente no meio rural (Carvalho, 1996). A renda per capita situa-se em torno de 2.800 dólares, inferior à média brasileira, que è de 4.000

\subsection{A CULTURA DE TOMATE}

O tomate é uma planta pertencente à familia das solanáceas, denominada cientificamente Lycopersicum esculentum Mill ou Lycopersicum lycopersicum L., potencialmente perene e com facilidade de 
adaptação a uma grande variedade de climas, com exceção daqueles nos quais as geadas estão presentes (Rodriguez e col., 1997).

O cultivo do tomate tem como origem a região andina e está difundido em praticamente todo o continente sul-americano. Porém, foi provavelmente no México que alguns tipos foram inicialmente melhorados e, eventualmente, introduzidos na Europa e aceitos como planta ornamental. Na Europa, acreditava-se ser uma planta tóxica, em virtude da sua relação com as plantas da familia das solanáceas, como a beladona; apenas posteriormente se soube que o alcalóide, conhecido por tomatina, presente sobretudo em folhas e frutos verdes, sofre degradação durante o amadurecimento. Superada essa primeira fase, o seu cultivo e consumo alcançaram tal difusão que hoje dificilmente se pode encontrar outro produto agricola que seja consumido nas mesmas quantidades que o tomate (Rodriguez e col., 1997).

No século 16, o tomate foi introduzido na região do Mediterrâneo, e seu cultivo para consumo alimentar teve inicio na Itália e na França, no século 17, quando era conhecido como maçã dourada e maçã do amor (Bieche, 1997).

Atualmente, o tomate è a hortaliça de maior consumo no mundo: o fruto fresco alcança $31,8 \mathrm{~kg}$ per capitalano na Espanha; $13,8 \mathrm{~kg}$ per capita/ano na Itália e $8,6 \mathrm{~kg}$ per capitalano na França; o tomate em conserva atinge $25,5 \mathrm{~kg}$ per capitalano nos Estados Unidos. O consumidor americano não é tão exigente quanto o europeu, e o tomate fresco não tem tanta importância nos Estados Unidos como na Europa; por essa razão, o cultivo naquele país não é, predominantemente, estaqueado, a colheita é 
mecânica e o fruto nunca alcança a qualidade e a apresentação exigidas no mercado europeu (Rodriguez e col., 1997).

O consumo de tomate na América do Sul vem aumentando consideravelmente, acompanhando as mudanças econômicas e sociais. Uma quantidade maior de mulheres no mercado de trabalho, um menor tempo para compras e para fazer refeições em casa, a migração de pessoas da área rural para a urbana, entre outras razōes, vêm acarretando um aumento no consumo de tomate, o qual está presente em pizzas, massas, cachorros quentes, sanduiches e em outros alimentos disponiveis em cardápios rápidos. O consumo dos paises do Mercosul é de $5,35 \mathrm{~kg}$ per capitalano e, historicamente, vem aumentando $5 \%$ por ano (Argerich e col., 1997).

No Brasil, a demanda para produtos derivados do tomate, extrato e molho, aumentou $34 \%$ e $54 \%$, respectivamente, em 1993 e 1995 (Tabela 2). Estimativas do Governo Federal indicam que 35 milhões de brasileiros, após a reforma econômica (Plano Real), alcançaram nivel econômico para consumir novos produtos derivados do tomate, razão pela qual 10 milhões de dólares de investimentos foram desviados para projetos de processamento de tomate. Enquanto novas empresas, como Nestlé, Parmalat e Uncle Beans, entraram no mercado brasileiro, as tradicionais, CICA, Arisco e Etti, expandiram suas fábricas de conservas, e outras, como Sofruta e Ole, abriram novas fábricas (Argerich e col., 1997).

Em 1996, os paises do Mediterrâneo, França, Grécia, Itália Portugal, Espanha, Israel, Tunisia e Turquia, foram responsáveis por $33 \%$ da produção mundial; os Estados Unidos, Canadá e México, por $44 \%$; e os paises da América do Sul. por 9,9\% (Bieche, 1997; Sullivan, 1997). 
Tabela 2 - Consumo de produtos derivados do tomate no Brasil, em 1.000 toneladas (Argerich e col., 1997).

\begin{tabular}{cccc}
\hline produto & 1993 & 1994 & 1995 \\
\hline extrato & 63,8 & 67,4 & 85,1 \\
molho & 35,7 & 40,0 & 54,9 \\
\hline \hline
\end{tabular}

Apesar da menor produção atual de tomate nos países da América do Sul, estudos indicam uma tendência mundial de aumento da competitividade no mercado internacional, em particular para os produtores do Chile e do Brasil (Sullivan, 1997).

A área total de plantação no Brasil, na Argentina e no Chile aumentou $30 \%$ nos últimos 4 anos, e a produção teve um incremento de $58 \%$, conforme mostra a Tabela 3. As principais razőes disso foram a melhoria na irrigação, na preparação do solo e no manejo de pragas (Argerich e col., 1997).

Tabela 3 - Desenvolvimento da produção de tomate nos principais países produtores da América do Sul (Argerich e col., 1997).

\begin{tabular}{|c|c|c|c|c|c|c|}
\hline \multirow[t]{2}{*}{ safra } & \multicolumn{2}{|c|}{ Brasil } & \multicolumn{2}{|c|}{ Argentina } & \multicolumn{2}{|c|}{ Chile } \\
\hline & $\begin{array}{l}\text { produção } \\
(t \times 1000)\end{array}$ & t/ha & $\begin{array}{l}\text { produçăo } \\
(t \times 1000)\end{array}$ & t/ha & $\begin{array}{l}\text { produçáo } \\
t \times 1000)\end{array}$ & t/ha \\
\hline $\begin{array}{l}1992-93 \\
1993-94 \\
1994-95 \\
1995-96\end{array}$ & $\begin{array}{l}707 \\
715 \\
700 \\
965\end{array}$ & $\begin{array}{l}43,8 \\
33,4 \\
32,0 \\
47,6\end{array}$ & $\begin{array}{l}130 \\
240 \\
190 \\
285\end{array}$ & $\begin{array}{l}17 \\
20 \\
22 \\
35\end{array}$ & $\begin{array}{l}488 \\
733 \\
822 \\
844\end{array}$ & $\begin{array}{l}57,4 \\
63,7 \\
76,0 \\
70,3\end{array}$ \\
\hline
\end{tabular}

No Brasil, a área de cultivo está localizada em 3 regiões: região 1 , Pernambuco e Bahia, com $45 \%$ e $35 \%$ da área e da produçăo total, respectivamente; região 2, Goiás e Minas Gerais, com $25 \%$ e $31 \%$ da área e da produção total, respectivamente; e região 3, São Paulo, com $29 \%$ e $33 \%$ da área e da produção total, respectivamente (Tabela 4). 
Tabela 4 - Produção de tomate no Brasil, por regiões (Argerich e col., 1997).

\begin{tabular}{|c|c|c|c|c|}
\hline Hegloos & 1993 & 1094 & 1996 & 41996 \\
\hline $\begin{array}{l}\text { região } 1 \text { (PE/BA): } \\
\text { - área (ha) } \\
\text { - tonelada (× 1000) } \\
\text { - produção (t/ha) }\end{array}$ & $\begin{array}{l}5.200 \\
155 \\
29,8\end{array}$ & $\begin{array}{c}7.670 \\
292,2 \\
38\end{array}$ & $\begin{array}{c}9.750 \\
350 \\
35,9\end{array}$ & $\begin{array}{c}8.292 \\
302,2 \\
36,4\end{array}$ \\
\hline $\begin{array}{l}\text { região } 2 \text { (GO/MG): } \\
\text { - área (ha) } \\
\text { - tonelada ( } \text { ( 1000) } \\
\text { - produção (t/ha) }\end{array}$ & $\begin{array}{c}5.250 \\
262,5 \\
50\end{array}$ & $\begin{array}{l}5.690 \\
253 \\
44,5\end{array}$ & $\begin{array}{c}5.030 \\
300 \\
60\end{array}$ & $\begin{array}{c}4.620 \\
263,8 \\
57\end{array}$ \\
\hline $\begin{array}{l}\text { região } 3(\mathrm{SP}) \text { : } \\
\text { - área (ha) } \\
\text { - tonelada (x 1000) } \\
\text { - produção (t/ha) }\end{array}$ & $\begin{array}{c}5.690 \\
237,4 \\
41,7\end{array}$ & $\begin{array}{c}6.380 \\
275,5 \\
43,2\end{array}$ & $\begin{array}{c}5.490 \\
279,7 \\
51\end{array}$ & $\begin{array}{c}5.280 \\
280 \\
53\end{array}$ \\
\hline $\begin{array}{l}\text { Brasil: } \\
\text { - área (ha) } \\
\text { - tonelada (x 1000) } \\
\text { - produçäo (t/ha) }\end{array}$ & $\begin{array}{c}16.140 \\
654,9 \\
40,6\end{array}$ & $\begin{array}{c}19.740 \\
820,7 \\
41,6\end{array}$ & $\begin{array}{c}20.270 \\
929,7 \\
45,8\end{array}$ & $\begin{array}{c}18.192 \\
846 \\
46,5\end{array}$ \\
\hline
\end{tabular}

Segundo estimativa da FAO (1995b), 21,9\% da população brasileira economicamente ativa encontra-se na agricultura. Nesse contexto, o cultivo do tomate, sobretudo do fruto para processamento, é um dos itens mais importantes na agricultura do Brasil, onde existem 18 empresas com uma capacidade instalada para 2 milhões de toneladas de tomate cru (Argerich e col., 1997).

De acordo com a Associação Brasileira da Indústria de Alimentos (ABIA), em 1995, 273.000 toneladas de produtos derivados do tomate foram vendidas no mercado brasileiro por um valor próximo a 500 milhões de dólares. A exportação brasileira também é economicamente considerável, tendo atingido, em 1996, 18.679 toneladas de extrato de tomate, o que corresponde a 22 milhões de dólares (Argerich e col., 1997). 


\subsubsection{ASPECTOS FITOSSANITÁRIOS DO TOMATEIRO}

A planta do tomate é susceptivel ao ataque de um grande número de pragas e doenças, que causam sérias perdas a produção e diminuem a qualidade do fruto. O dano econômico causado aos produtores pelo ataque de parasitas torna os programas de proteção essenciais em todas as áreas de cultivo de tomate (Rincón, 1997).

Estima-se que 67.000 diferentes espécies de pragas ataquem a agricultura em todo o mundo. No cultivo do tomate, são diversas as pragas e as enfermidades possiveis, dentre as principais, destacam-se: a) insetos (lagarta, mosca branca, traça, pulgão) e ácaros; b) nematóides; c) bactérias; d) fungos que afetam a folhagem (propagação aérea); e) fungos que causam enfermidades vasculares, radiculares e na base do talo; f) viroses: TMV (Tomato Mosaic Virus), PVY (Potato virus Y), CARNA 5 (virus da necrose do tomate). TSWV (Tomato Spotted Wilt Virus) e TYLCV (Tomato Yellow Leaf Curly Virus); g) enfermidades fisiológicas ou acidentais: apodrecimento do extremo floral, tomates secos, rachaduras no tomate, queda da flor, danos pelo frio e por intensidade luminosa (Rodriguez e col., 1997).

Os ataques fúngicos provocam doenças como ferrugem precoce (Alternaria solani), ferrugem tardia (Phytophthora infestans) e antracnose (Colletotrichum phomoides (Sacc.) (Chester), e Colletotrichum coccodes (Wallr.) são comuns, sendo capazes de comprometer toda a plantação de tomate (Cheah, 1985).

Condiçōes climáticas, como alta umidade e temperatura e muita chuva. favorecem o desenvolvimento da antracnose, doença de grande 
ocorrència no tomate para processamento (Precheur, 1992). As lesōes causadas pela antracnose no fruto são fatores determinantes do uso e do preço do tomate, podendo haver variação semanal: em uma mesma semana, os preços são distintos por categoria e qualidade do fruto, podendo variar em até $20 \%$. Uma ou duas lesōes por fruto pode justificar seu descarte. Assim, apenas $1 \%$ de fruto infectado pode diminuir o preço pago pelos processadores ao produtor, e $4 \%$ de fruto afetado implica uma significante perda no preço por tonelada (Cheah, 1985; Precheur, 1992).

Em Pernambuco e na Bahia, as principais doenças são as tospoviroses, causadas por TSWV, TCSV e GRSV, e as pragas mais significativas sào a traça do tomateiro (Scrobipalpulloides absoluta), a mosca branca (Bemisia tabaci e argentifolli) e os nematóides (Meloidogyne incognita e javanica).

Praticamente a cada safra a cultura do tomate é ameaçada por novas pragas. Em 1996, a maior incidência foi "vira-cabeça" e mosca branca. Em 1997, a mosca branca, Bemisia tabaci Gennadius, causou graves prejuizos nos campos da regiāo do São Francisco. A situação é dificil, uma vez que esse inseto é capaz de infestar 506 espécies de plantas e transmitir 90 doenças viróticas, além de adquirir rápida resistência a todos os grupos de inseticidas, e a grande quantidade de plantas nas quais se hospeda favorece a sua reprodução de forma ininterrupta. O surto de mosca branca no Brasil vem ocorrendo desde 1958, quando afetou o algodão. Entre 1972/73, o inseto teve sua população ampliada nos plantios de soja, algodão e feijāo no norte do Paraná e na regiăo de Ourinhos, SP. Nos anos 90, foram constatadas infestaçōes nas culturas de tomate, algodão, abóbora e em plantas 
ornamentais, como crisântemo e bico-de-papagaio, na região de Campinas, SP.

A mosca branca se desenvolve tanto em hortaliças cultivadas em telados dos paises europeus quanto em cultivos abertos dos paises tropicais e subtropicais e tem sido objeto de intenso estudo nos últimos anos devido aos danos em diferentes cultivos (Rodriguez e col., 1997).

\subsubsection{O USO DE PRAGUICIDAS NA CULTURA DO TOMATE}

Em razão das pragas e enfermidades que podem atingir a cultura do tomate, o uso de praguicidas é elevado, sobretudo para a prevenção dessas manifestações. Nas últimas décadas, a técnica mais difundida no combate dessas pragas, que incluem insetos, patógenos e erva daninha, tem sido o uso de produtos químicos (Bull e Hathaway, 1986; Bieche, 1997)

Antes da plantação, por exemplo, o solo é desinfetado com produtos fumigantes, as sementes são pulverizadas com fungicidas antes do transplante, e, após 8-15 dias, è usual a aplicaçăo de herbicidas (Rodriguez e col., 1997). No tomate tutorado (ou estaqueado), há tratamento fitossanitário quinzenal, muitas vezes por meio de helicópteros ou avião para grandes superficies ou através de mangueiras com muitas adaptações feitas por pequenos produtores (Rincón, 1997).

O controle quimico das lagartas desfoliadoras, das brocas do fruto (praga de grande importância para o tomate de mesa) e das lagartas de solo ou cortadoras com inseticidas em regiōes de extenso cultivo de 
tomate vem passando por problemas de resistência, o que justifica a busca constante de produtos novos lançados no mercado que rompam essa resistência (Rodriguez e col., 1997).

No primeiro controle de lagartas, por exemplo, o inseticida organoclorado DDT foi utilizado durante a época de cultivo, porém, com o passar do tempo, as doses foram aumentando, assim como o número de aplicaçōes e a adição do lindano, outro organoclorado. A resistência ao DDT também implicou na introdução do carbaril, inseticida carbamato com pouca eficácia no controle da lagarta em todo o mundo e, posteriormente, do triclorfon, inseticida organofosforado, sendo este o mais efetivo durante a década de 60. A partir do desenvolvimento de resistência também ao triclorfon, foram aplicadas misturas contendo outro produto clorado, o endosulfan (Rodriguez e col., 1997).

No principio dos anos 70 , o triclorfon não apresentava efeito, mesmo em dose quatro vezes superior à recomendada, sendo, então, substituido pelo metomil, inseticida da classe dos carbamatos. Apesar da boa eficácia inicial desse produto, após dois a três anos de uso generalizado, seu efeito decaiu consideravelmente. Na fase posterior ao metomil, o inseticida organofosforado metamidofós foi incorporado na luta contra as lagartas do tomate, sendo utilizado até hoje com resultados irregulares (Rodriguez e col., 1997).

Nos anos 80, apareceram as piretrinas sintéticas (piretróides), atualmente empregadas com maior freqüência no controle dos insetos, como a permetrina, a cypermetrina e a deltametrina. No entanto, o uso constante de piretróides acarretou a proliferação de ácaros, o que justificou a utilização de novos produtos com efeito acaricida. Em algumas 
regiōes de plantio de tomate, o emprego preventivo de Bacillus thuriginensis, Thuricide \&, responsável pelo aparecimento de uma enfermidade irreversivel nas lagartas, vem representando uma alternativa viável, sem perturbar o equilibrio ecológico (Rodriguez e col., 1997).

No que se refere ao controle químico da mosca branca, trata-se de um processo dificil e oneroso, devido à resistência que as larvas apresentam aos inseticidas de uso mais corrente. Produtos organofosforados, como dimetoato, metamidofós e azinfós, têm alguma ação contra os insetos adultos e larvas mais jovens, enquanto que fungicidas, como zineb e maneb, parecem agir como ovicidas (Rodriguez e col., 1997). Contudo, avanços vêm sendo obtidos pelo uso de imidachloprid, inseticidas de outros grupos e de óleo mineral (França e Arruda, 1997).

Contra a antracnose, os principais produtos são mancozeb, clorotalonil e anilazine, sendo o primeiro fungicida o mais popular entre os produtores. No combate às bactérias, novamente os fungicidas são bastante indicados, como, por exemplo: zineb, maneb, mancozeb e clorotalonil. Os tratamentos preventivos e periódicos são o único meio de controle durante o cultivo, e os produtos mais utilizados são maneb, mancozeb, zineb+cobre, captan e clorotalonil (Cheah, 1985; Precheur, 1992).

Devido à ação de fungos pós-colheita, causadores de sérios danos econômicos, é importante, também, o uso de fungicidas nessa etapa. Porém, deve-se conhecer a meia vida desses fungicidas, os quais podem representar riscos para a saúde pública (Cheah, 1985; Precheur, 1992). 
O tomate rasteiro parece apresentar um certo grau de resistência, ou seja. nas mesmas condiçōes de outras modalidades de cultivos, ele tem sido menos infestado por pragas. Os predadores encontram ambientes melhores no tomate rasteiro em relação ao estaqueado. Levantando-se as camadas do tomate rasteiro, encontram-se os citados inimigos naturais das pragas entre os detritos e folhas (Rodriguez e col., 1997).

Após a Segunda Guerra Mundial, um grande número de produtos químicos foram desenvolvidos com base na filosofia de que a prevençăo é melhor do que a cura. No entanto, os programas de prevenção, ao usarem uma série de tratamentos, embora mostrassem sucesso em diminuir as doenças, apresentavam graves problemas, como a necessidade de um número excessivo de tratamentos de custo elevado, o desenvolvimento de patógenos resistentes a alguns ingredientes ativos dos praguicidas, a destruição dos inimigos naturais dos patógenos e a persistência de residuos tóxicos de produtos, contaminando o ambiente e o fruto. Atualmente, no cenário mundial, profundas mudanças na tecnologia e na filosofia de proteção da planta implicaram uma outra estratégia: o uso racional de praguicidas, aliado a métodos de controle biológico e melhoramento genético (Rincón, 1997).

Segundo Bull e Hathaway (1986), o uso de praguicidas permite a sobrevivência de um grupo da população de pragas com caracteristicas genéticas ou de comportamento que permitem a elas reduzir a quantidade de produtos quimicos que penetram em seu corpo, eliminar esses produtos de seu organismo ou sobreviver aos seus efeitos tóxicos de alguma outra forma. Ao se reproduzirem, esses insetos transferem essa capacidade de 
sobrevivência a seus descendentes, até que uma grande proporção da população de pragas torna-se totalmente resistente.

Assim, o uso intensivo de praguicidas na cultura do tomate pode ser danoso para o próprio processo produtivo, à medida que provoca resistências de pragas, resultando em uma crescente aplicação de novos produtos e no uso de fórmulas combinadas de praguicidas, cuja ação sobre a saúde humana e o meio ambiente sāo pouco conhecidas dos usuários, de grupos humanos expostos e da fiscalização pública (Bull e Hathaway, 1986; Rodrigues e col., 1997).

O tomate e seus derivados já foram considerados responsáveis por $15 \%$ do risco oncogênico estimado na dieta total (Precheur, 1992). Por outro lado, um estudo realizado na Califórnia sugere que os produtos derivados de tomate, como suco, extrato e enlatado, contêm menos do que $4 \%$ do residuo original após o processamento (Precheur, 1992).

$\mathrm{Na}$ atual legislação brasileira, constam 91 principios ativos registrados para uso na cultura do tomate (ILSI-Brasil, 1995), o que gera cerca de 144 produtos comerciais (Coordenação da Fiscalização de Agrotóxicos, AGROFIT/1997). Porém, como ocorre com outros produtos agricolas, os principios ativos de uso permitido na cultura do tomate variam de acordo com os paises produtores, motivados por estudos próprios ou seguindo orientação de agências internacionais, como a Comissão do Codex Alimentarius (1995), que estabelece um total de 78 principios ativos para uso como praguicidas no tomateiro.

Com o objetivo de harmonizar os praguicidas utilizados na cultura do tomate a ser comercializado entre os paises membros do Mercosul, os 
limites máximos de resíduos de praguicidas foram estabelecidos para apenas 10 princípios ativos, indicados na Tabela 5 (Mercosur, 1995).

Tabela 5 - Limites Máximos de Resíduos (LMR) de praguicidas estabelecidos para o comércio intra-regional do Mercosul.

\begin{tabular}{lc}
\hline \multicolumn{1}{c}{ principlo atlvo } & $\begin{array}{c}\text { Limites Máximos de Residuos - } \\
\text { LimR (m g/kg) }\end{array}$ \\
\hline \hline captan & 15 \\
carbofuran & 0,1 \\
clorpirifós & 0,5 \\
demeton-s-metil & 0,5 \\
diazinon & 0,5 \\
dimetoato & 1,0 \\
fenitrotion & 0,5 \\
fosfamidon & 0,1 \\
malation & 3,0 \\
triclorfon & 02 \\
\hline \hline
\end{tabular}

\subsubsection{CULTIVOS ALTERNATIVOS}

O primeiro programa de tratamento integrado para tomate industrial teve início na Califórnia, no começo dos anos 80 . Desde então, programas similares foram adotados por produtores de outras regiões, o que significou uma grande reduçăo do uso de praguicidas e fertilizantes e, conseqüentemente, um considerável decréscimo de resíduos nos frutos (Rincón, 1997).

Na Europa, o avanço da aplicação de esquemas de controle integrado em cultivos protegidos tem sido muito grande. $O$ uso de parasitas e predadores de muitas pragas fez nascer uma nova indústria, as biofábricas, onde estão as metodologias mais sofisticadas para a produção em massa de auxiliares para o controle biológico (Rodriguez e col., 1997). 
O melhoramento genético já tem conseguido cultivos portadores de resistência para certas doenças e pragas, além de avanços no sentido de melhorar a qualidade do tomate para processamento e para consumo in natura. Dessa forma, os novos agricultores terão produçōes de melhor qualidade, frutos resistentes a doenças e uma menor necessidade do uso de praguicidas. Atualmente, o uso de herbicida, por exemplo, é inevitável, visto que a seleção das sementes é essencial para o desenvolvimento da safra. Porém, o controle de doenças e epidemias deve estar de acordo com um programa integrado que combine controle químico com manejo adequado e explore resistência genética e controle biológico (Rincón, 1997).

A traça do tomateiro, por exemplo, foi motivo de grande preocupação em 1989, quando comprometeu 40 a $50 \%$ da produção do Vale do São Francisco. A importância do estabelecimento de um calendário de produção, a obrigatoriedade de destruição de restos de culturas e do receituário agronômico nas propostas de financiamento, além da necessidade de uma assistência técnica mais efetiva aos produtores, a partir da divulgaçāo de resultados de pesquisa, do uso adequado de praguicidas e do treinamento sobre manejo integrado de pragas em tomateiro, vêm sendo exaustivamente discutidas desde então, entre técnicos e pesquisadores da EMBRAPA / Centro de Pesquisas Agropecuárias do Trópico Semi-Árido (CPATSA), Empresa Pernambucana de Pesquisa Agropecuária-IPA e Universidade Federal Rural de Pernambuco-UFRPE (Haji, 1989; Ferreira e col., 1995; Silva e col., 1995; França e Arruda, 1997). 
O programa de manejo integrado da traça do tomateiro, implantado pela EMBRAPA/CPATSA, adota, como prática principal, o uso do parasitóide de ovos Trichogramma pretiosum. Nesse programa, o uso de inseticidas é recomendado apenas em casos emergenciais, havendo preferência pelos menos tóxicos e seletivos ao referido parasitóide. Nesse contexto, os inseticidas clorfluazurom (Atabron (B), teflubenzurom (Nomolt(8) e abamectim (Vertimec (8) foram avaliados, sendo os dois primeiros os produtos mais promissores para uso no manejo integrado de pragas do tomateiro (Prezotti e col., 1996).

Recentemente, pesquisadores do IPA estudaram variedades geneticamente melhoradas de tomate industrial e de mesa. O produto proposto para o tomate destinado às indústrias é mais tolerante a altas temperaturas e resistente a pragas do tipo vira-cabeça e fusarium raças 1 e 2. A equipe de pesquisadores está em fase de implementação de unidades demonstrativas que visam à difusão das informações consideradas úteis em outros paises na cultura do tomate, tais como: armadilhas, calendário de cultivo, aplicação sistematizada de produtos químicos, destruição de restos de cultura, adubação correta, horário e modo de aplicação dos praguicidas e produção de mudas protegidas. Uma das experiências em andamento diz respeito à produção de mudas em telados, duas unidades já foram instaladas no estado, com participaçāo direta de produtores e empresários locais (França e Arruda, 1997).

A importância sócio-econômica da agricultura do Perímetro Irrigado do Vale do São Francisco tem motivado o desenvolvimento de pesquisas relacionadas com o manejo integrado de pragas na região, sendo o tomateiro uma das culturas de grande interesse. No entanto, essa 
alternativa representa um desafio para os especialistas em manejo integrado. uma vez que inumeras pragas encontram no tomateiro condições ideais de atuação.

\subsection{A CULTURA DE TOMATE NO ESTADO DE PERNAMBUCO}

No Estado de Pernambuco, existe a produção do tomate destinado à indústria de processamento, chamado tomate rasteiro, por ser cultivado diretamente no chão, e a do tomate de mesa, chamado de estaqueado, maior e de melhor aparência que o primeiro. O tomate industrial é produzido, predominantemente, na região irrigada do Vale do São Francisco, próxima ao Municipio de Petrolina, localizada na Mesorregiāo São Francisco Pernambucano. O tomate de mesa, por sua vez, tem seu maior cultivo no Agreste Pernambucano, sendo o Municipio de Camocim de São Félix representativo dessa produção na regiāo (Figura 1).

Em 1992, a produção do Estado foi de 324.921 toneladas, sendo 204.110 toneladas provenientes do São Francisco Pernambucano, que corresponde a 6.076 ha de area colhida (Instituto de Planejamento de Pernambuco, 1995).

A produção de tomate de mesa de Pernambuco representa cerca de $70 \%$ da movimentação no entreposto comercial da Companhia de Abastecimento e de Armazéns Gerais do Estado de Pernambuco CEAGEPE, com maior participação dos Municipios de Camocim de São Felix e Sāo Joaquim do Monte, localizados na Microrregiāo Brejo Pernambucano. De 1986 a 1995, a média anual dos preços apresentou 
uma taxa de crescimento de $8,53 \%$, com volume médio próximo a 20.000 t/ano, representando cerca de 7.000 empregos gerados na região dos Brejos de Pernambuco (CEAGEPE, 1996).

Na safra de tomate industrial para 1996. Pernambuco respondeu por $26 \%$ da produção nacional, abaixo apenas de São Paulo, com $30,1 \%$. Porém, somando-se as produções dos Estados de Pernambuco e Bahia, visto que o tomate industrial tem praticamente a mesma origem, ou seja, o vale irrigado do São Francisco, a produção passou a ser $37,2 \%$, portanto, a maior do pais.

O Projeto Senador Nilo Coelho, localizado no perimetro irrigado do Vale do São Francisco, em Petrolina, possui 172 empresas e cerca de 1.824 colonos. Considerando o ano de 1996 como base, a área irrigada plantada total é de $14.614,91$ ha, dos quais $1.845,90$ ha são destinados à cultura do tomate. A produção total de tomate é de 89.820 .56 toneladas, o que representa uma produtividade de 47,06 t/ha e proporciona uma receita ao produtor de $\mathrm{R} \$ 21.893 .755,16$. O número de empregos gerados, diretos fixos e temporários e indiretos, é da ordem de $61.013,88 / a n o$, dos quais 1.391,62 são relacionados com a cultura do tomate industrial (CODEVASF, 1996).

O tomate representa a segunda maior produção agricola do Estado de Pernambuco, contribuindo com cerca de RS 170 milhōes/ano. A área utilizada na plantação de tomate no Estado, em 1996, foi de 7.630 ha, contra 409.674 ha para a cana-de-açúcar e 36.760 ha para a banana, culturas responsáveis pelo primeiro e terceiro maiores valores da produção agricola do Estado, respectivamente (Tabela 6). No entanto, considerando 
- valor da produçãolárea, a cultura do tomate representou o maior valor médio, $\mathrm{R} \$ 22.698,00 /$ ha.

Tabela 6 - Valores brutos da produção agrícola do Estado de Pernambuco, safra 1996.

\begin{tabular}{|c|c|c|c|c|c|}
\hline produto & $\begin{array}{l}\text { frea } \\
(\text { ha) }\end{array}$ & $\begin{array}{l}\text { producalo } \\
(y)\end{array}$ & $\begin{array}{l}\text { produtivldado } \\
\text { (Wha) }\end{array}$ & $\begin{array}{c}\text { valor bruto } \\
\text { da } \\
\text { produgaro } \\
(R s)\end{array}$ & 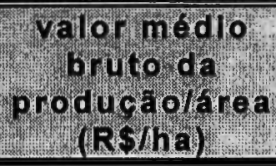 \\
\hline $\begin{array}{l}\text { cana de } \\
\text { açúcar }\end{array}$ & 409.674 & 20.376 .644 & 49,73 & 366.779 .592 & 895 \\
\hline tomate & 7.630 & 293.536 & 38,47 & 173.186 .240 & 22.698 \\
\hline banana & 36.760 & 48.524 & 1,32 & 126.162 .400 & 3.432 \\
\hline $\begin{array}{c}\text { feijăo } \\
\text { phaseolus }\end{array}$ & 162.574 & 102.256 & 0,62 & 73.760 .661 & 454 \\
\hline milho & 355.760 & 291.319 & 0,81 & 73.897 .920 & 208 \\
\hline mandioca & 83.259 & 836.017 & 10,04 & 49.926 .935 & 600 \\
\hline feijăo vigna & 230.870 & 93.643 & 0,40 & 48.148 .109 & 208 \\
\hline uva & 2.626 & 48.338 & 18,40 & 38.670 .400 & 14.726 \\
\hline
\end{tabular}

FONTES: IBGE/GCEA/LSPA, DIDOC/DPLAN/EMATER-PE.

Elaboração: SECTMA-PE.

\subsubsection{CARACTERIZAÇÃO DE REGIÕES DE GRANDE PRODUÇÃO DE TOMATE NO ESTADO}

- Projeto de Irrigação Senador Nilo Coelho - mesorregião São

\section{Francisco Pernambucano / Petrolina}

As áreas irrigadas e irrigáveis às margens do Rio São Francisco e de alguns de seus afluentes vêm-se constituindo em regiōes de agricultura moderna, pela utilização intensiva de insumos, máquinas e equipamentos. As culturas irrigadas são dirigidas, na sua quase totalidade, para os 
mercados interno e externo ou ao aproveitamento agroindustrial na própria região, sobretudo as de tomate e suco de frutas. A regiāo tem recebido investimentos de empresários locais e de outras regiōes. Nas atividades primárias, prevalecem as relações de produçāo com base no assalariamento, embora a parceria seja importante (CODEVASF, 1989: Carvalho, 1996).

Os principais objetivos do Programa de Irrigação do Vale do São Francisco são: a) incrementar a produção agricola para atender ao crescente mercado interno e proporcionar um melhor aproveitamento para as possibilidades de exportação; b) introduzir familias da população rural pobre da região em projetos de desenvolvimento rural integrado; c) criar novos empregos a fim de inverter o processo de migração para áreas urbanas do litoral ou para o Sul; d) dar continuidade à implantação de indústrias de processamento de produtos agricolas (CODEVASF, 1989).

Os sistemas de irrigação adotados no pólo são o de gravidade, através de inundaçōes, o de sulcos de infiltração, gotejamento, aspersão simples e o de pivô central (Melo, 1997).

O perimetro irrigado do Vale do Sāo Francisco representa, atualmente, um desafio para a comunidade agronômica brasileira, em virtude da sua importância econômica e social frente às particularidades regionais, no que se refere a caracteristicas e manejo de um solo arenoso e ácido.

O sistema de irrigaçāo é efetivo, engenhoso e, ao mesmo tempo, conta com todos os recursos modernos necessários. Observa-se, porém, uma diferença na qualidade de algumas áreas em relação a outras, no que diz respeito a problemas de drenagens, profundidade do solo e manejo 
inadequado e/ou descuido do agricultor. Essas diferenças podem afetar de modo notável a produçāo. por conseguinte a renda do agricultor, além do meio ambiente.

Denominado anteriormente Projeto Vale do Massangano, o Projeto de Irrigação Senador Nilo Coelho, área de estudo selecionada para este trabalho, surgiu a partir da preocupação do Governo Federal de dar apoio ao desenvolvimento do Nordeste através da agricultura irrigada. Seu objetivo maior era elevar os niveis de renda e diminuir o êxodo de familias do campo para as áreas urbanas. Em 1979, com o apoio do Banco Interamericano de Desenvolvimento - BID, teve inicio a execução do Projeto pela Companhia de Desenvolvimento do Vale do São Francisco CODEVASF, empresa pública que, na época, era vinculada ao então Programa Nacional de Irrigaçāo - PRONI e hoje está subordinada ao Ministério do Meio Ambiente, dos Recursos Hidricos e da Amazônia Legal (CODEVASF, 1989).

O custo de implantação desse projeto está estimado em 180 milhōes de dólares, distribuidos na montagem do sistema geral de irrigação por aspersão e drenagem, na implantação do sistema de lotes ocupados pelos pequenos produtores, na administração das obras e nos serviços de engenharia, consultoria e treinamento de pessoal (Melo, 1997).

O Projeto Senador Nilo Coelho localiza-se no Submédio São Francisco, junto a outros cinco perímetros de irrigação: Bebedouro, Mandacaru, Tourão, Curaçá e Maniçoba. Circunda a zona urbana da cidade de Petrolina e estende-se até o Municipio de Casa Nova, à jusante do reservatório de Sobradinho, no Estado da Bahia. É uma das regiōes mais secas do Nordeste. integrante do chamado "Poligono das Secas", 
com cerca de $500 \mathrm{~mm}$ anuais de precipitação pluviométrica, distribuidos irregularmente durante o ano, além de uma elevada evaporação. Como grande parte do interior do Nordeste, a regiāo caracteriza-se por sua baixa produtividade agricola e baixa renda per capita, com densidade demográfica menor que 10 habitantes $/ \mathrm{km}^{2}$ (CODEVASF, 1989).

Em 1985, a irrigação do Projeto Senador Nilo foi estabelecida para cobrir uma área de 15.000 hectares do sertão do São Francisco Pernambucano, que seria distribuida entre familias de baixa renda, chamadas de colonos $(60 \%) ; 75$ fazendas de porte médio, com 20 a 60 ha $(30 \%)$; e cerca de 8 agroindústrias, com áreas médias de 350 ha $(20 \%)$ Em média, os colonos teriam 6 hectares, enquanto que os empresários poderiam ter até 1.000 ha (CODEVASF, 1989). Consta, na programaçāo da CODEVASF para 1997/98, a expansão do projeto por mais 4.798 ha de área irrigada (CODEVASF, 1996).

Em 1996, o Projeto Senador Nilo Coelho teve 14.769 ha em operação, dos quais 9.319 ha correspondiam a 11 núcleos de colonização, subdivididos em lotes com cerca de 120 produtores por núcleo, formados por pequenos agricultores (1.442 colonos), e 5.450 ha contendo 131 empresas.

A baixa pluviosidade da regiāo, aliada à elevada taxa de infiltração dos solos, torna impossivel a existência de uma agricultura de sequeiro rentável. Assim, o Projeto Senador Nilo Coelho, junto com os outros cinco perimetros de irrigação, tem contribuido para a criação de um importante pólo de desenvolvimento rural, denominado Petrolina/Juazeiro. Nessa regiāo, vêm ocorrendo aumentos significativos da produçāo e da exportação, assim como a oferta de empregos permanentes, o que reflete 
na melhoria dos niveis de renda da população. A expansão da irrigação tem dinamizado o mercado de trabalho local, houve um aumento significativo na demanda da força de trabalho, o que atraiu a população tanto dos municipios vizinhos como de outros estados da região Nordeste (CODEVASF, 1989).

O número de empregos transitórios diretos criados pelo projeto na fase de implantação alcançou um total de 5.956, que, somado aos empregos agricolas permanentes, chegou a um total de 10.840 empregos. Em 1996, o número de empregos gerados pelo projeto, diretos fixos e temporários indiretos, foi de $61.013,88$ nos $14.614,91$ hectares plantados. Estima-se que, com a expansão da área irrigada em 1997/98, mais 48.000 empregos serão criados. É importante ressaltar que o emprego nas agroindústrias é relativamente pouco importante, se comparado com o emprego agricola permanente (CODEVASF, 1989; CODEVASF, 1996).

A razão principal da geração de empregos diretos no cultivo irrigado da regiāo do vale está no fato de que as culturas básicas exploradas, frutas e hortaliças, utilizam a mecanização somente em algumas etapas do processo de cultivo, como a aração, o sulcamento e a gradagem, enquanto as demais etapas são realizadas manualmente (Melo, 1997).

Paralelamente à infra-estrutura de irrigação por aspersão, no perimetro do Projeto Senador Nilo Coelho, foi construida uma infraestrutura social e de serviços. Foram organizados onze núcleos habitacionais, contendo entre 80 a 180 residências, com saneamento básico e energia elétrica, acesso para as áreas agricolas e centros de serviços. Hoje, existem 1.796 residências em plenas condições de uso (CODEVASF, 1989). 
Em convênio com o Governo do Estado de Pernambuco, em cada núcleo foram criadas pequenas escolas de $1^{\circ} \mathrm{grau}$, e três escolas de $2^{\circ}$ grau foram construidas estrategicamente em relação aos 11 núcleos habitacionais. Em 1996, as escolas estavam com 4.898 alunos inscritos (CODEVASF, 1989; CODEVASF, 1996).

Em Petrolina, está sediado um núcleo gerencial de todo o projeto, com oficinas, pátio de mecanização, posto de lavagem e lubrificação de máquinas e veículos. Observa-se, portanto, que esse não foi só um projeto de irrigação, mas existiu, também, a preocupação de realizar, paralelamente, um desenvolvimento rural da área: "o valor que tem esse projeto em termos do seu beneficio líquido para o pais como um todo é maior que a sua rentabilidade como empresa" (CODEVASF, 1989).

As principais culturas, por ordem de produção em toneladas, sāo tomate, banana, manga, melancia, uva e feijão, cuja receita total registrada para o ano de 1996 foi de R\$ 65.917.315,99 (CODEVASF, 1996). A área cultivada total correspondeu a $14.614,91$ ha, inferior à do ano de 1995. A queda foi motivada pela tendência natural da implantação de culturas permanentes (abacate, acerola, aspargo, banana, caju, cana, capim, carambola, citricos, coco, graviola, goiaba, laranja, lichia, macadamia, mamão, manga, maracujá, pinha, tangerina e uva), que ora ocupam $65,2 \%$ de sua área total, superando, assim, as culturas temporárias (abóbora, alface, batata-doce, cebola, cenoura, coentro, crotalária, feijāo, jiló, girassol, mandioca, melancia, melāo, milho, pimentão, quiabo, repolho, tomate).

Apesar da irregularidade entre a produtividade das culturas de um ano para o outro, em média, os empresários apresentam uma maior 
produtividade de culturas e um maior indice de uso do solo que os colonos. Além disso, contam com uma estrutura de produção mais diversificada e uma maior proporção de culturas permanentes e, sobretudo, melhor tecnologia do que os colonos. No periodo 1984/88, a produtividade média dos colonos nas culturas do tomate era superior à dos empresários, diferentemente do que ocorreu em relação a outras culturas, bem como à produtividade meta e média do pais (CODEVASF, 1989). Atualmente, a produtividade, em t/ha, é de 46,61 e 50,17 para os colonos e empresários, respectivamente (CODEVASF, 1996).

Os empresários têm menores riscos na produção agricola e, conseqüentemente, maiores possibilidades de incrementar sua renda ou pelo menos mantê-la. Por outro lado, por investirem basicamente em culturas temporárias e sem muita diversidade, os colonos assumem maiores riscos na produção agrícola, apresentando, portanto, menores possibilidades de incrementar suas rendas (CODEVASF, 1989).

Nos primeiros anos de operação do projeto, existiu uma extensāo elou uma assistência técnica adequada aos colonos, sobretudo no tocante aos serviços sociais, tendo sido, entretanto, minima a capacitação dos colonos e evidente a falta de investimentos para o pequeno produtor rural ou o pessoal de baixa renda. Os colonos não obtinham crédito para culturas perenes por não disporem da garantia real, exigida pelos bancos, e pela dificuldade de encontrarem um avalista. O crédito agrícola não é uma variável controlada pelo projeto, depende da politica financeira nacional, que, por sua vez, depende, também, da problemática da divida externa e de exigências, tais como a retirada dos subsidios. Assim, a primeira avaliação técnica do projeto concluiu que a assistência aos 
colonos não estava sendo eficiente elou efetiva, "faltou investir muito mais no homem: o pequeno produtor rural ou pessoal de baixa renda" (CODEVASF, 1989)

Através de contrato, a CODEVASF repassou a operação e a manutenção do perimetro ao Distrito de Irrigação do Perimetro Senador Nilo Coelho, associação civil de direito privado, de caráter coletivo, sediada na cidade de Petrolina. Esse fato, aliado ao acompanhamento técnico-científico do grupo de pesquisadores da EMBRAPA - Centro de Pesquisa Agropecuária do Trópico Semi-Árido (CPATSA), resultou em um considerável melhoramento na assistência aos produtores, sobretudo aos colonos. No último relatório técnico gerado pela CODEVASF, por exemplo, consta que 104 projetos de financiamento para custeio foram elaborados por colonos, apesar de o crédito agricola continuar com as limitaçōes bancárias nas linhas de crédito. Por outro lado, no que se refere à infraestrutura social, a situação ainda è considerada deficiente, uma vez que estāo disponiveis apenas 3 ambulatórios, 1 médico/clínico geral, 4 técnicos em enfermagem, 1 odontologista e 1 agente de saúde (CODEVASF, 1996)

As culturas irrigadas utilizam insumos de capital, como fertilizantes, praguicidas e maquinaria agricola, em proporçōes altas, sobretudo na cultura da uva, seguida pela do tomate, da cebola e da melancia. De uma maneira geral, a comercialização de insumos e produtos no projeto é realizada de forma isolada, sobretudo no caso de colonos, que ficam à mercê de "atravessadores" e outros comerciantes.

Evidentemente, na sua fase inicial, não existiam grandes agressōes ao meio ambiente. No entanto, no que se refere à manipulação de 
praguicidas, desde o inicio, não havia diretrizes para a proteção dos trabalhadores envolvidos na pulverização dos produtos, o que fez surgir, naquela ocasião, casos graves de intoxicação. Com o aumento da produção, era previsivel o aumento da exposição ocupacional a esses produtos (CODEVASF, 1989).

Em lugar algum do projeto existia a preocupação com a possivel contaminação por praguicidas dos trabalhadores, da água do rio São Francisco, do solo e mesmo do alimento produzido. Quase 10 anos após o relatório inicial de avaliação (CODEVASF,1989), no qual se chamava a atenção para a possibilidade de ampliação dos registros de intoxicação e grandes impactos ambientais, a situação continua a mesma, ou seja, sem politica preventiva aos danos decorrentes do uso de praguicidas para a saúde humana e ambiental.

- Municipio de Camocim de São Félix - Mesorregião Agreste

\section{Pernambucano}

O Municipio de Camocim de São Félix, área de estudo selecionada para este trabalho, localiza-se na Microrregião Brejo Pernambucano e conta com uma área de $50,9 \mathrm{~km}^{2}$. E limitado ao Norte pelo Municipio de Bezerros, ao Sul por Bonito e São Joaquim do Monte, a Leste por Sairé e a Oeste por Sapucarana e Boas Novas. Está a $692 \mathrm{~m}$ acima do nivel do mar e dista $123 \mathrm{~km}$ de Recife (Anuário estatístico de Pernambuco, 1995).

A precipitação pluviométrica anual é de $1.085 \mathrm{~mm}$ (média histórica), com chuvas ocorrendo entre os meses de março a setembro, estando o periodo de maior estiagem entre outubro e dezembro. Em termos de recursos hidricos, tem as bacias hidrográficas de Sirinhaém $\left(60 \mathrm{~km}^{2}\right)$, do 
Ipojuca $\left(12 \mathrm{~km}^{2}\right)$ e do Una $\left(10 \mathrm{~km}^{2}\right)$. O clima predominante é do tipo quente úmido, com temperatura média de $24^{\circ} \mathrm{C}$ (Anuário estatistico de Pernambuco, 1995).

Camocim de São Félix foi fundada por um grupo de individuos que, chegando à regiāo, organizaram um povoado chamado "Camocim", posteriormente "Vila de Camocim", pertencente ao Municipio de Bezerros. Foi elevado à categoria de municipio e cidade em 1953, passando a se chamar Camocim de São Félix, em homenagem ao santo padroeiro São Félix. A sua localização em terras com muita água foi fundamental para o progresso observado posteriormente.

A população estimada é de 13.834 habitantes, com um contigente rural de 3.313 habitantes, dos quais 1.713 são homens e 1.601 mulheres. As principais áreas de concentração populacional (vilas e povoados) estão resumidas na Tabela 7 , na qual se observa uma proximidade entre essas vilas e povoados e o centro do municipio.

Quanto às unidades de prestação de assistência médico-sanitária, o município é dotado de uma unidade mista, com sete leitos para maternidade, dois postos de saúde municipais e uma clínica de olhos (privada). Quanto a profissionais de saúde locais, há um médico, que atende duas vezes por semana, três enfermeiras e dois dentistas. 
Tabela 7 - Principais áreas de concentração populacional de Camocim de São Félix.

\begin{tabular}{lccccc}
\hline \multicolumn{1}{c}{ vila/povoado } & populaçăo & $\begin{array}{c}\text { distância da sede } \\
(\mathbf{k m})\end{array}$ & \multicolumn{2}{c|}{$\mathbf{n}^{\circ}$ de produtores } \\
\hline \hline Pacas & & 15 & prop. & parc. & arrend. \\
Santa Luzia & 752 & 06 & 158 & 19 & 52 \\
Serra de Aires & 165 & 15 & 98 & 18 & 39 \\
Cruz de Rajada & 503 & 04 & - & - & - \\
Palmeiras & 425 & 06 & 85 & 08 & 26 \\
Mocós & 546 & 12 & 105 & 11 & 32 \\
Brejinho & 154 & 08 & 142 & 10 & 48 \\
\hline \hline
\end{tabular}

prop.: proprietário; parc.: parceleiro; arrend.: arrendatário

FONTE: EMATER-PE, 1992, 1996.

A região tem elevado analfabetismo, $54 \%$ para maiores de 15 anos e, na zona rural, chega a cerca de $72 \%$ (Silva, 1991; Anuário estatístico de Pernambuco, 1995).

Tradicionalmente, o Agreste tem sido o celeiro de alimentos que convergem para os grandes centros urbanos do Estado. Nos brejos de altitude, que incluem, total ou parcialmente, municípios como Camocim de São Félix, Bezerros e Garanhuns, prevalecem os micro e pequenos proprietários que se dedicam à produção de cereais, frutas e hortaliças, além da criação de gado bovino para corte e leite (Carvalho, 1996). As culturas de tomate, repolho, pimentão, pepino e milho săo as que têm maior quantidade de produtores envolvidos e maiores áreas cultivadas, porém, quanto à produtividade, a laranja, o milho e o feijão são as que se destacam.

A comercialização da produção agrícola ocorre através dos chamados atravessadores, que levam os produtos para a CEASA do Recife-PE, São Luís-MA, Belém-PA e João Pessoa-PB e para as feiraslivres das cidades circunvizinhas. 
Existem deficiências de informação quanto à estrutura fundiária de Camocim de São Félix, pois os dados relativos a "posse da terra" não foram levantados pelo senso do IBGE. No entanto, em 1992, a EMATERPE fez um levantamento que revelou que $70 \%$ dos produtores de hortaliças são arrendatários, perfazendo um número de 210 produtores em áreas de 1,0 hectare, em média.

Segundo Silva (1991), a distribuição de terra é desigual, a irrigação artificial ocorre sem critérios técnicos, há excesso de adubos químicos e o solo encontra-se empobrecido.

A agricultura existente aponta para um sério problema de saúde pública. A aplicação de praguicidas ocorre sem o cumprimento das boas práticas agricolas e de orientação técnica, além disso, não existem, até o momento, mecanismos de cadastramento, controle, tratamento ou acompanhamento da população exposta diretamente aos riscos no campo.

Em virtude de as plantações existentes, principalmente de tomates, localizarem-se nas margens do reservatório hídrico que abastece a cidade, o uso de praguicidas sem controle ou fiscalização é algo preocupante. A população local acredita que a contaminação por praguicidas é generalizada, atingido até mesmo a água distribuida pela Companhia de Abastecimento-COMPESA e causando sérios danos à saúde dos moradores.

Além dos praguicidas, os esgotos domésticos podem contribuir consideravelmente para a contaminação bacteriológica das águas dos reservatórios e da água consumida pela população (ITEP, 1997). O saneamento inexiste e é usual a comercialização de água proveniente de "chafariz" por particulares; esse abastecimento é canalizado para as 
residências dos interessados e, pelo que se sabe, não há qualquer tipo de fiscalização sanitária. A questão da água é crítica, pois, além de insuficiente, è de péssima qualidade. Há queixas de que tem mau cheiro e provoca prurido na pele quando usada para o banho.

- reservatório que abastecia a cidade, Tanque das Piabas, encontra-se interditado devido a suspeitas de contaminação, sobretudo por esgotos domésticos e praguicidas. Assim, o Municipio de Camocim de São Félix vem sendo abastecido, desde 1990, pelo Reservatório Poço de Areia, localizado no municipio de Bezerros (ITEP, 1997).

Segundo avaliação da Diretoria de Meio Ambiente da Secretaria de Ciência, Tecnologia e Meio Ambiente do Estado (SECTMA, 1996), Camocim de São Félix exerce uma grande pressão sobre o recurso florestal. A razão principal disso é a demanda ocasionada pelas 32 serrarias existentes no municipio, as quais desdobram madeira para a confecção de caixotes destinados ao acondicionamento da produção agricola, sobretudo de tomates de mesa ( 750.000 caixas/ano). O setor industrial, casa de farinha, padaria e olaria, também contribui para o elevado consumo de lenha e carvão. Essas atividades, ao longo do tempo, vêm trazendo alguns problemas ao municipio, no que diz respeito ao uso dos recursos naturais.

Com o auxilio do Ministério do Meio Ambiente, Recursos Hidricos e Amazônia Legal, será executado um programa de educação ambiental em algumas regiōes do Estado, o qual inclui um trabalho de extensão e assistência técnica em Camocim de São Félix, através da orientação quanto à conservação do solo e uso de praguicidas. O co-executor do 
projeto será a Prefeitura Municipal de Camocim de São Félix (SECTMA, 1996)

Resumidamente, as principais caracteristicas do Municipio de Camocim de São Félix, que o tornam representativo para o presente estudo, sāo:

a) trata-se de um municipio representante de muitas outras situaçōes próprias das áreas semi-áridas de Pernambuco, que pode exemplificar a vulnerabilidade inerente dos ecossistemas dessas regiōes;

b) o Municipio experimentou transformações ambientais, tais como: desflorestamento, monocultura e pecuária;

c) os processos sociais são semelhantes aos de outros locais do Nordeste;

d) o municipio padece as conseqüências da completa interação entre a sociedade e o meio ambiente, tais como: um amplo espectro de problemas ecológicos, alterações hidrológicas, degradação do solo (erosão, salinização), perda de recursos bióticos e contaminaçāo de diversas naturezas;

e) à luz desses acontecimentos, a populaçāo (grupos sociais majoritários) apresenta severas deficiências em suas condiçōes de vida e de saúde.

Esses processos de deterioração sócio-ambiental não são independentes entre si, estão relacionados com um conjunto de mudanças nas propriedades estruturais do sistema sócio-ambiental envolvido, de natureza bastante complexa. 


\subsection{A SITUAÇÃO DOS PRAGUICIDAS EM PERNAMBUCO}

Existem evidências de uso abusivo e intoxicações por praguicidas em diferentes regiōes rurais do Estado de Pernambuco, porém não existem registros dos mesmos, pela falta de uma politica de monitoramento, para a qual é essencial, entre outros requisitos, a existência de um laboratório capacitado para a deteç̧ão de residuos tóxicos.

Segundo Silva (1991), o desconhecimento da legislação, o descumprimento das constituições federal, estadual e municipal e dos códigos penal e civil, a falta de informação de usuários, a não utilização do receituário agronômico, a omissão de funcionários e de órgãos públicos e o pouco conhecimento de técnicos de serviços de extensão rural, fazem de Pernambuco um dos grandes consumidores de praguicidas do pais.

Certamente, em Pernambuco, a legislação é pouco conhecida da maior parte dos órgãos que têm atribuições dessa natureza, e as açōes em desenvolvimento carecem de integração e eficácia.

Estudos realizados no Estado de Pernambuco nos últimos anos revelam a existência de ações de informação e de diagnóstico da situação da exposição ocupacional aos praguicidas em algumas regiōes do Estado (Silva, 1991; Luna e col., 1995; FUNDACENTRO, 1996; Fischer e Melo, 1996; Melo, 1997; Teixeira e Brandão, 1998), porém, essas iniciativas apresentam características isoladas, não gerando, portanto, um conhecimento integrado nem tampouco uma politica voltada para os aspectos de prevenção dos problemas relacionados à saúde e à proteção ambiental.

Em uma dessas ações, a atividade da acetilcolinesterase foi 
determinada, no periodo de 1991 a 1992, em trabalhadores rurais do municipio de Camocim de São Félix. Com a utilizaçāo do kit Lovibond (®, amostras de sangue foram analisadas $e$, segundo os autores, os resultados indicaram intoxicação por inseticidas inibidores da colinesterase em 56 dos $431(13 \%)$ individuos selecionados (Luna e col., 1995). Os resultados, porém, não foram confirmados por outra técnica de maior precisão.

As condições de trabalho no municipio de Camocim de São Félix são semelhantes àquelas encontradas em outras regiōes rurais, onde se pôde observar a ausência absoluta de qualquer tipo de equipamento de proteção individual (EPIs), a escassez de água para a lavagem ou o uso em caso de acidente, a falta de instruçōes técnicas, a reutilização de embalagens para a armazenagem de alimento ou bebida, a dificuldade em ler/entender instruçōes do rótulo, a alimentação do produtor e da familia no local de trabalho ou durante a aplicação, o uso da mesma roupa durante vários dias ou semanas e, sobretudo, a falta de autoridades regulamentadoras e de fiscalização (Silva, 1991; Carvalho, 1996; Fischer e Melo, 1996; FUNDACENTRO, 1996; Melo, 1997).

Algumas situaçōes irregulares e preocupantes ocorridas em Camocim de São Félix foram registradas por pesquisadores e/ou pela imprensa, por exemplo: uma foto foi divulgada pelo Jornal do Comércio, Recife (Silva, 1991), na qual uma criança prepara a mistura (calda) de praguicidas para a aplicação em cultivos de tomate (Figura 2). A Figura 3 , obtida no mesmo municipio, mostra a aplicação de praguicidas por crianças/adolescentes, vestidos apenas com calções curtos e camisetas (Silva, 1991). 


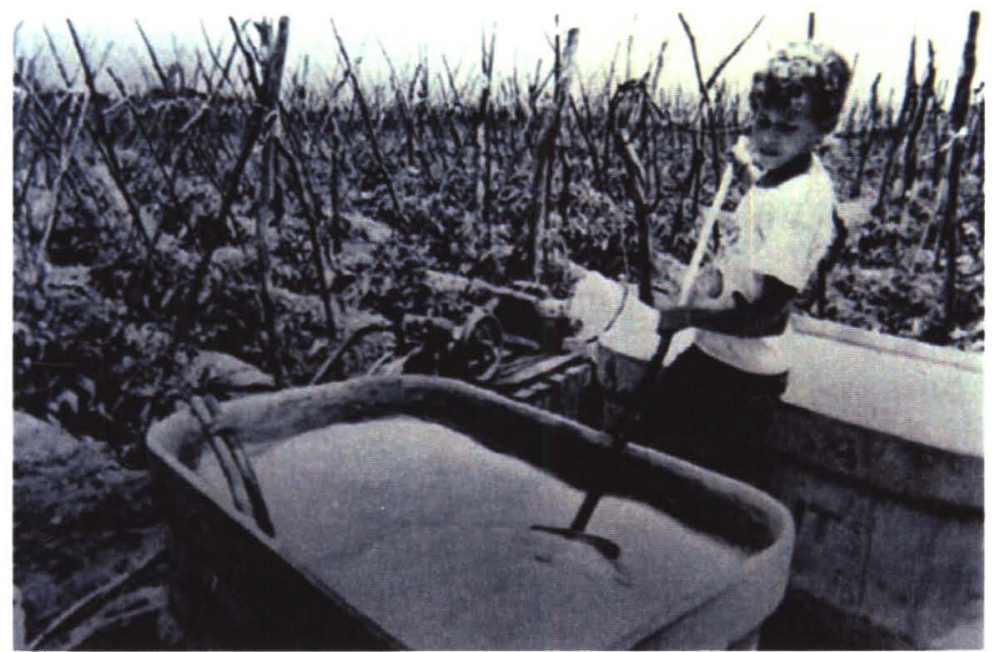

Figura 2 - Preparação da mistura de praguicidas para aplicação na cultura de tomate do Municipio de Camocim de São Félix (Silva, 1991).

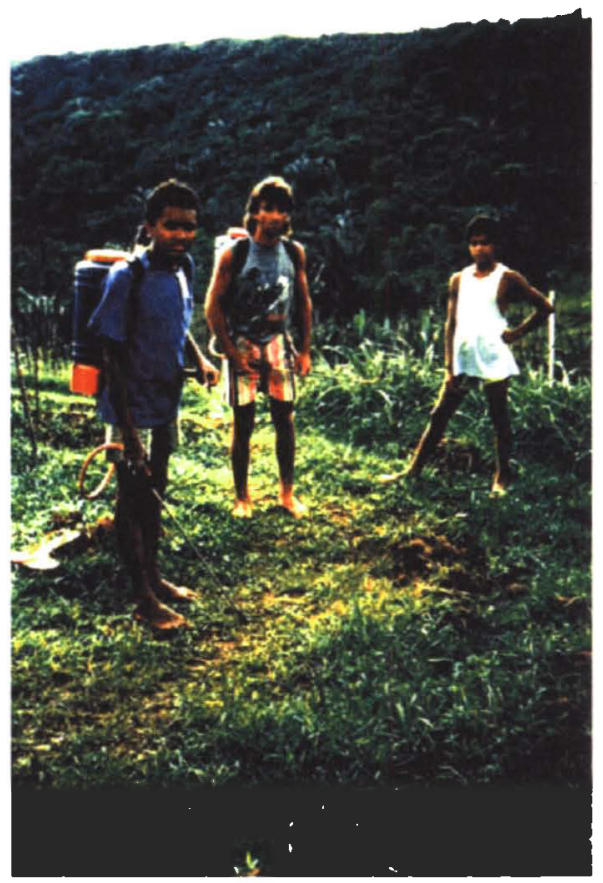

Figura 3 - Aplicação de praguicidas no Municipio de Camocim de São Félix (Silva, 1991). 
O uso ilegal de praguicidas também foi registrado: foram encontrados produtos banidos pela legislação brasileira, como o aldrin; de uso não permitido na agricultura ou específico para determinadas culturas, como o BHC, O DDT e o endosulfan; ou de registro desconhecido, como o Atta-mex e o Vazepion (Silva, 1991).

Segundo depoimento de agricultores da região, ainda é comum o uso de BHC e aldrin em culturas de hortaliças (Silva, 1991). As entrevistas realizadas por Silva (1991) mostraram que a maneira de lidar com os praguicidas é fruto de experiências pessoais, conforme mostram os relatos a seguir:

Faz 15 anos que eu trabalho com esse tipo de produto, até mesmo com o BHC... Aldrin só prejudica se você aplicar a dosagem alterada. Nós pulverizamos o tomate, com dois ou três dias, os meninos comem o tomate até sem lavar e nunca fez mal... Eles querem aplicar tudo de uma vez, que é para acabar mais rápido com a praga, ai é que aumenta a praga.

A terra contaminada não tem possibilidade de prejudicar os rios, só as pragas.

O tomate, depois que cresce, fica na altura da gente, ai eles pulverizam o veneno ao lado deles, e morrem. 0 outro mexe o veneno com a própria mão. 
Você planta um pé de tomate $e$, se näo botar agrotóxico nele, você não tira tomate, apodrece antes de amadurecer... O Dithane nāo é tóxico, não capina. não cheira nem nada.

Basta eu passar o veneno que não agüento, é uma dor de cabeça medonha.

Eu ouvi falar que as pessoas morrem com o veneno, mas não sei qual é o veneno... Eu só vejo é: fulano morre envenenado, mas não sei qual é a qualidade do veneno.

Danos no sistema auditivo foram relacionados com o uso de praguicidas por trabalhadores da Zona da Mata Pernambucana, no Municipio de Vitória de Santo Antão. O resultado da avaliação de 98 trabalhadores com idade média de 38 anos e mais de cinco anos em atividade na lavoura indicou uma tendência de perda auditiva em $57 \%$ dos examinados, os quais, em exame preliminar, não apresentaram obstrução do canal auditivo externo, deficiência auditiva de etiologia congênita ou idade superior a 59 anos (Teixeira e Brandão, 1998).

$\mathrm{Na}$ mesorregião São Francisco Pernambucano, nos Municipios de Petrolândia e Santa Maria da Boa Vista, foi elaborado um trabalho, durante o periodo de 1993 a 1996, com o objetivo de conhecer a população exposta aos praguicidas na lavoura, a qual foi classificada segundo alguns fatores, como condição sócio-econômica, idade, sexo, escolaridade, 
instruções recebidas, atividade exercida, tipo de contato com praguicidas, produtos mais utilizados, além de dados que pudessem evidenciar uma possivel intoxicação. Foram aplicados questionários a 1.193 trabalhadores, tendo todos eles fornecido sangue para avaliação da exposição aos inibidores da acetilcolinesterase, através da utilização do kit Lovibond (8) (FUNDACENTRO, 1996). Os resultados indicaram que $12,4 \%$ da população estudada apresentaram atividade da colinesterase abaixo de $75 \%$, porém não foram feitas correlações diretas entre os resultados sangüineos e as informações da população obtidas através dos questionários. Nesse levantamento, os produtos referidos como sendo os mais utilizados pertenciam às classes dos inseticidas organofosforados, em especial, o metamidofós, o paration metil, o profenofós e o monocrotofós, e o fungicida mancozeb, pertencente à classe dos etilenobisditiocarbamatos.

No perímetro irrigado do Vale do São Francisco, na mesorregião do São Francisco Pernambucano, os produtores/colonos indicaram ter um maior conhecimento a respeito do risco oferecido pelos praguicidas, provavelmente em conseqüência de uma certa organização já existente. Prova disso é o fato de o colono rejeitar o trabalho de pulverização, contratando terceiros, os quais, em função dos danos à saúde relacionados aos praguicidas e do número reduzido de interessados, estabeleceram que o valor da diária na pulverização é sempre superior ao das demais atividades. Por outro lado, mesmo tendo ouvido falar dos riscos envolvidos no trabalho com os praguicidas, nas localidades irrigadas, o aplicador comumente pulveriza esses produtos sem fazer uso de qualquer tipo de equipamento de proteção, pois, na sua opinião, o Equipamento dificulta a respiração. 
Apesar de a taxa de analfabetismo dos trabalhadores do perímetro irrigado do Nordeste ser de $29,6 \%$, de uma maneira geral, eles estão conscientes dos efeitos negativos dos praguicidas sobre a saúde, especialmente de suas conseqüências mais imediatas. Poucos, contudo, estão conscientes de que eles podem causar prejuízo a longo prazo (Fischer e Melo, 1996).

Em 1996, Fischer e Melo realizaram uma pesquisa, de cunho social, sobre o trabalho rural feminino nos perímetros irrigados e registraram como principais queixas de saúde: a dor de cabeça, seguida de problemas de coluna, doenças de pele, infecções, males dos aparelhos respiratório e digestivo. As infecções, relatadas por diversas trabalhadoras, ocorriam, principalmente, nos órgãos ginecológicos e estavam associadas à colheita do tomate, durante a qual as mulheres trabalhavam quase sentadas. É importante esclarecer que a mulher não pulveriza, mas, quando está colhendo, tem contato direto com o praguicida. Nessa região, a colheita do tomate rasteiro, para fins industriais, era realizada quase que exclusivamente por mulheres e estava definida como uma atividade feminina. As autoras registraram vários depoimentos dessas mulheres, trabalhadoras do tomate, alguns dos quais foram transcritos:

O pó do tomate dá coceira...

O agrotóxico dá muita doença. A pessoa fica roxa, manchada ou vermelha e vomita. Vai para o médico, toma uma injeção e fica boa.

O pêlo do tomate incha os olhos. 
No começo, quando iniciei na irrigação, eu vomitava e tinha vertigem, depois me acostumei.

$\mathrm{Na}$ colheita do tomate, a mulher respira o pó do tomate. Este pó dá dor de cabeça, amargor na boca, tontura. Dá problema na pele e na cabeça.

A irmã da minha avó (trabalhadora do tomate) morreu por causa do veneno... O médico disse que foi doença que pegou no plantio... Ela morreu de câncer.

O veneno fica no tomate. Os olhos coçam, sinto coceira nos braços. Quando tomo banho, passo tomate podre no corpo para facilitar a retirada do pêlo, preciso passar muito sabão no corpo.

Quando chego em casa, tenho de tomar banho para sair o verde do tomate. É preciso passar sabão duas vezes. O pó do tomate dá problema na pele e na cabeça. Quando chego em casa sinto a pele arder, formigar, depois de meia hora passa.

O veneno fica na folha do tomate. Quando a gente respira, fica com falta de ar e a vista fica parda, o nariz entope e os olhos coçam. 
Eu trabalho no tomate todo o tempo, até quando estou grávida. Acho que isso prejudicou meu filho, porque ele já está com mais de 2 anos e não anda.

Seria bom ter um lugar para discutir os problemas... A gente quando está lavando roupa fala das doenças.

A ocorrência de intoxicação ocupacional por praguicidas no Vale do São Francisco, a qual às vezes provoca óbitos, é admitida por alguns empregadores da cultura do tomate e técnicos do Projeto de Irrigação (Fischer e Melo, 1996).

Segundo informações de trabalhadores da cultura de uva daquela região, o médico contratado pela empresa, arbitrariamente, desaprova os atestados de saúde concedidos por outros médicos, principalmente à mulher, tornando-os sem efeito ou reduzindo o número de dias do licenciado; essa queixa foi formalizada e denunciada pelo Sindicato dos Trabalhadores Rurais de Petrolina/Pernambuco ao Conselho de Medicina do Estado (Melo, 1997). Segundo Melo (1997), o comportamento desrespeitoso praticado pelo profissional da Medicina pode ser usado como mecanismo para levar o trabalhador a não interromper sua atividade profissional para cuidar da saúde, dentro ou fora da empresa e reflete o modelo conservador de administração efetivado pela empresa, o qual dá pouca importância aos recursos humanos.

Existem outros aspectos culturais da região, que constituem ameaça permanente à saúde dos trabalhadores, como, por exemplo: a água 
potável nos locais de trabalho e o trabalho infantil. Como na colheita o pagamento é por produção, para não perder tempo, o trabalhador consome a água proveniente dos canais de irrigação, possivelmente contaminada por produtos quimicos. Na versão das entrevistadas, a partir dos cinco anos, um menino deve começar a ajudar ao pai na lavoura e, se não trabalhar, "vira malandro" (Fischer e Melo, 1996).

O emprego oferecido por colonos absorve, na maioria das vezes, os trabalhadores rurais que não conseguem um contrato permanente de trabalho nas empresas agricolas de maior porte. Diferentemente do que ocorre em relação às empresas, os colonos contratam trabalhadores rurais de acordo com a produção, sem salário fixo. Nessas condições, permitem a entrada de menores para ajudarem os pais nas tarefas agricolas e remuneram apenas a força de trabalho adulta contratada (Melo, 1997).

Mesmo apresentando os problemas relatados, estando longe do nivel considerado satisfatório, a educação na área agricola em processo de modernização avançou significativamente em relação às áreas de cultivo tradicionais, de acordo com Fischer e Melo (1996).

No que se refere ao meio ambiente, o único trabalho de investigação analítica sobre a contaminação ambiental por praguicidas no Estado de Pernambuco foi realizado em 1995/96. Trata-se de um diagnóstico da qualidade da água do Rio Ipojuca identificando os trechos mais criticos de contaminação, na tentativa de rastrear as principais fontes poluidoras. 0 estudo abrangeu o período de seca e estiagem, tendo sido incluidos pontos de coleta ao longo de toda a Bacia do Rio Ipojuca, localizada nas mesorregiões do Agreste, da Mata e Metropolitana, e um total de $250 \mathrm{~km}$. Foram detectados niveis de inseticidas organoclorados acima dos aceitos 
pela Resolução CONAMA, dentre eles alguns de uso proibido (Araújo e col., 1998).

Devido, sobretudo, à insuficiência laboratorial para a análise de resíduos de praguicidas, o Estado de Pernambuco não possui dados analíticos em qualquer tipo de alimento, de origem vegetal ou animal, anterior a este trabalho. Porém, observando-se os dados existentes no país, essa situaçåo, infelizmente, é bastante comum em vários outros estados. A Tabela 8 mostra os principais trabalhos analiticos realizados no pais, referentes a resíduos de praguicidas em alimentos, com objetivo de controle, monitoramento ou avaliaçăo. Dos 36 trabalhos analisados, 25 foram realizados com amostras coletadas no Estado de São Paulo, não havendo registro de estados do Nordeste.

Tabela 8- Principais trabalhos publicados no país, referentes ao monitoramento, controle ou avaliação de resíduos de praguicidas em alimentos.

\begin{tabular}{|c|c|c|c|c|c|c|}
\hline ordem & alimento & $\begin{array}{l}\text { praguicidas } \\
\text { analisados }\end{array}$ & $\begin{array}{l}\text { ano de } \\
\text { execucăo }\end{array}$ & estado & $\begin{array}{l}\text { orgăo } \\
\text { exécutor }\end{array}$ & referencla \\
\hline 01 & carne bovina & $\begin{array}{l}\text { inseticidas } \\
\text { organoclorados }\end{array}$ & 1969 & SP & IAL & Lara e col., 1971 \\
\hline 02 & leite & $\begin{array}{l}\text { inseticidas } \\
\text { organoclorados }\end{array}$ & 1970 & SP & IAL & Almeida e Barretto, 1971 \\
\hline 03 & água & $\begin{array}{l}\text { inseticidas } \\
\text { organoclorados }\end{array}$ & 1972 & SP & IAL. & Lara e Barretto, 1972a \\
\hline 04 & $\begin{array}{c}\text { arroz, feijăo, } \\
\text { farinha, ovos, } \\
\text { hortaliças, } \\
\text { óleo vegetal }\end{array}$ & $\begin{array}{l}\text { inseticidas } \\
\text { organoclorados }\end{array}$ & 1972 & SP & IAL & Lara e Barretto, 1972b \\
\hline 05 & $\begin{array}{l}\text { sardinha, } \\
\text { atum, } \\
\text { salsicha, pate } \\
\text { de flgado }\end{array}$ & $\begin{array}{c}\text { inseticidas } \\
\text { organoclorados }\end{array}$ & $1977 / 1978$ & $S P$ & ITAL & Yokomizo, 1979 \\
\hline 06 & $\begin{array}{c}\text { came, peixe, } \\
\text { hortaliças, } \\
\text { leite e } \\
\text { derivados }\end{array}$ & $\begin{array}{l}\text { inseticidas } \\
\text { organoclorados }\end{array}$ & $1978 / 1979$ & PR & SUREHMA & Tiboni, 991 \\
\hline
\end{tabular}




\section{Continuação da Tabela 8.}

\begin{tabular}{|c|c|c|c|c|c|c|}
\hline 07 & carne bovina & $\begin{array}{c}\text { inseticidas } \\
\text { organoclorados }\end{array}$ & $1978 / 1979$ & SP & LARA & Carvalho e col., 1980 \\
\hline 08 & $\begin{array}{l}\text { frutas, } \\
\text { hortaliças }\end{array}$ & $\begin{array}{l}\text { inseticidas } \\
\text { organoclorados } \\
\text { e fosforados }\end{array}$ & $1978 / 1980$ & SP & IB & Úngaro e col., 1980 \\
\hline 09 & $\begin{array}{c}\text { grãos de trigo } \\
\text { e de soja }\end{array}$ & $\begin{array}{l}\text { inseticidas } \\
\text { organoclorados }\end{array}$ & $1978 / 1981$ & RS & CIENTEC & CIENTEC. 1981 \\
\hline 10 & $\begin{array}{c}\text { frutas e } \\
\text { hortaliças }\end{array}$ & $\begin{array}{l}\text { inseticidas } \\
\text { organoclorados } \\
\text { e fosforados }\end{array}$ & $1978 / 1983$ & SP & IB & Ungaro e col. 1985 \\
\hline 11 & $\begin{array}{c}\text { leite } \\
\text { pasteurizado }\end{array}$ & $\begin{array}{c}\text { inseticidas } \\
\text { organoclorados }\end{array}$ & 1979 & SP & $\mid A L$ & Lara e col., 1980a \\
\hline 12 & $\begin{array}{l}\text { carne bovina } \\
\text { processada }\end{array}$ & $\begin{array}{c}\text { Inseticidas } \\
\text { organoclorados }\end{array}$ & $1979 / 1980$ & SP & LARA & Nishikawa e col., 1982 \\
\hline 13 & leite materno & $\begin{array}{l}\text { inseticidas } \\
\text { organoclorados }\end{array}$ & $1979 / 1981$ & SP & IAL & Lara e col.. 1982 \\
\hline 14 & $\begin{array}{l}\text { feijāo, soja, } \\
\text { cacau, alho, } \\
\text { amendoim. } \\
\text { arroz, banana }\end{array}$ & fosfina & 1980 & SP & $\mid A L$ & Barretto e col., 1984 \\
\hline 15 & $\begin{array}{c}\text { peixes, } \\
\text { camarōes. } \\
\text { ostras }\end{array}$ & $\mathrm{BHC}, \mathrm{DDT}$ & 1980 & SP & $\mid A L$ & Lara e col., 1980b \\
\hline 16 & carne bovina & $\begin{array}{c}\text { inseticidas } \\
\text { organoclorados }\end{array}$ & 1980 & MG & $\mid A L$ & Maia e Brant, 1980 \\
\hline 17 & $\begin{array}{c}\text { leite } \\
\text { pasteurizado }\end{array}$ & $\begin{array}{c}\text { inseticidas } \\
\text { organoclorados }\end{array}$ & $1980 / 1981$ & $\mathrm{SP}$ & $\mid A L$ & Lara e col., 1985 \\
\hline 18 & $\begin{array}{c}\text { leite em pó, } \\
\text { manteiga, } \\
\text { queijo }\end{array}$ & $\begin{array}{c}\text { inseticidas } \\
\text { organoclorados }\end{array}$ & $1980 / 1982$ & SP & ITAL & Yokomizo e col., $1984 a$ \\
\hline 19 & $\begin{array}{c}\text { hortaliças, } \\
\text { pêssego, trigo }\end{array}$ & $\begin{array}{l}\text { inseticidas } \\
\text { organoclorados } \\
\text { e fosforados }\end{array}$ & $1982 / 1983$ & PR & TECPAR & Tiboni, 1991 \\
\hline 20 & $\begin{array}{c}\text { frutas, } \\
\text { hortaliças }\end{array}$ & $\begin{array}{l}\text { inseticidas } \\
\text { organoclorados } \\
\text { e fosforados }\end{array}$ & 1983 & $S P$ & 18 & Ungaro e col., 1983 \\
\hline 21 & $\begin{array}{c}\text { frutas, } \\
\text { hortaliças }\end{array}$ & $\begin{array}{l}\text { inseticidas } \\
\text { organoclorados } \\
\text { e fosforados }\end{array}$ & $1983 / 1984$ & MG & CIAP & Soares, 1985 \\
\hline 22 & morango & $\begin{array}{c}\text { dicofol e } \\
\text { endossulfan }\end{array}$ & $1983 / 1988$ & SP & IB & Guindani e Ungaro, 1988 \\
\hline 23 & carne & $\begin{array}{c}\text { inseticidas } \\
\text { organoclorados }\end{array}$ & 1984 & SP & LARA & Carvalho e col., 1984 \\
\hline 24 & $\begin{array}{l}\text { óleos. } \\
\text { gorduras } \\
\text { vegetais }\end{array}$ & $\begin{array}{c}\text { inseticidas } \\
\text { organoclorados }\end{array}$ & 1984 & SP & ITAL & Yokomizo e col., 1984b \\
\hline 25 & $\begin{array}{l}\text { frutas, } \\
\text { hortaliças }\end{array}$ & $\begin{array}{l}\text { inseticidas } \\
\text { organoclorados } \\
e \text { fosforados }\end{array}$ & $1985 / 1986$ & SP & IB & Ungaro e col., 1987 \\
\hline
\end{tabular}


Continuação da Tabela 8.

\begin{tabular}{|c|c|c|c|c|c|c|}
\hline 26 & $\begin{array}{c}\text { frutas, } \\
\text { hortalicas }\end{array}$ & $\begin{array}{c}\text { inseticidas } \\
\text { organoclorados }\end{array}$ & 1986 & MG & UFMG & Soares. 1986 \\
\hline 27 & $\begin{array}{l}\text { frutas, } \\
\text { hortaliças }\end{array}$ & $\begin{array}{c}\text { fungicidas } \\
\text { ditiocarbamatos }\end{array}$ & $1986 / 1988$ & RJ & UFF & Reis e Caldas, 1991 \\
\hline 28 & $\begin{array}{l}\text { frutas, } \\
\text { hortaliças }\end{array}$ & $\begin{array}{l}\text { fungicidas, } \\
\text { herbicidas e } \\
\text { inseticidas } \\
\text { organoclorados } \\
\text { fosforados, } \\
\text { carbamatos e } \\
\text { piretróides }\end{array}$ & $1987 / 1992$ & PR & CSVS & Zandoná e Zappia, 1993 \\
\hline 29 & $\begin{array}{l}\text { hortaliças, } \\
\text { frutas }\end{array}$ & $\begin{array}{c}\text { inseticidas } \\
\text { organoclorados } \\
\text { e fosforados e } \\
\text { deltametrina }\end{array}$ & 1988 & PR & TECPAR & Tiboni, 1991 \\
\hline 30 & $\begin{array}{l}\text { gordura de } \\
\text { frango }\end{array}$ & $\begin{array}{c}\text { inseticidas } \\
\text { organoclorados }\end{array}$ & $1988 / 1991$ & SP & IAL & Barreto e col., 1992 \\
\hline 31 & maçă & dicofol & 1989 & PR & TECPAR & Tiboni, 1991 \\
\hline 32 & morangos & $\begin{array}{l}\text { Endosulfan, } \\
\text { dicofol, captan, } \\
\text { clorotalonil, } \\
\text { mancozeb }\end{array}$ & 1991 & SP & ITAL & Oliveira e Toledo, 1995 \\
\hline 33 & $\begin{array}{c}\text { frutos, } \\
\text { tubérculos }\end{array}$ & endosulfan & 1993 & SP & $\mathrm{IAL}$ & Lemes e col., 1993 \\
\hline 36 & $\begin{array}{l}\text { hortaliças, } \\
\text { carnes, leite, } \\
\text { arroz, feijăo, } \\
\text { farinha de } \\
\text { trigo, fubá }\end{array}$ & $\begin{array}{l}\text { inseticidas } \\
\text { organoclorados } \\
\text { e fosforados }\end{array}$ & 1994 & SP & IAL & Barreto e col., 1996 \\
\hline
\end{tabular}

CIAP: Centro Integrado de Apoio à Produção de Minas Gerais; CIENTEC: Fundação de Ciência e Tecnologia do Rio Grande do Sul; CSVS: Centro de Saneamento e Vigilância Sanitária do Paraná; IAL: Instituto Adolfo Lutz; IB: Instituto Biológico; ITAL: Instituto de Tecnologia de Alimentos; LARA: Laboratório Regional de Apoio Animal; SUREHMA Superintendência de Recursos Hidricos e Meio Ambiente do Paraná; TECPAR: Instituto de Tecnologia do Paraná; UFF: Universidade Federal Fluminense; UFMG: Universidade Federal de Minas Gerais; UFSM: Universidade Federal de Santa Maria

Apesar da falta de um monitoramento da qualidade dos alimentos comercializados no Estado de Pernambuco, há indicios de que o problema de contaminação por agentes químicos diversos existe e pode ser grave, como mostram resultados de alguns trabalhos realizados com lingüiça $e$ 
amendoim comercializados no Recife (Araújo e Ribeiro, 1992; Araújo e col., 1994).

O Estado de Pernambuco possui apenas levantamentos de uso na agricultura de praguicidas em alguns municipios, realizados pela Secretaria de Agricultura em 1997, EMATER-PE em 1990, 1994 e 1997 e pela Prefeitura de Camocim de São Félix em 1991. Esses dados foram obtidos através de questionários respondidos pelas prefeituras, sob a coordenação de técnicos das regionais do Departamento de Inspeção e Fiscalização Agropecuária da Secretaria de Agricultura e técnicos de extensão rural das regionais da EMATER-PE. No entanto, os resultados desses levantamentos não passaram por qualquer tipo de avaliação ou ação conjunta para um melhor aproveitamento, ficaram registrados apenas nos órgãos executores.

\subsection{INSETICIDAS ORGANOFOSFORADOS, INSETICIDAS} ORGANOCLORADOS E FUNGICIDAS DITIOCARBAMATOS

\subsubsection{INSETICIDAS ORGANOFOSFORADOS}

Os praguicidas inibidores da acetilcolinesterase, inseticidas organofosforados e carbamatos, são utilizados mundialmente em grande escala, sobretudo para substituir os inseticidas organoclorados persistentes. Um alto percentual da população está real e potencialmente exposto a essas substâncias, não só os individuos em atividades ocupacionais, mas os da comunidade em geral; há imensas possibilidades 
de esses compostos provocarem efeitos nocivos para a saúde (Centro Panamericano de Ecología Humana y Salud, 1991).

De acordo com a estrutura quimica, os inseticidas organofosforados podem ser classificados em fosforados (mevinfós), tiofosforados (paration metílico), clorofosforados (triclorfon) e flúor / cianofosforados (sarin) (Larini, 1993).

As vias de entrada preferenciais dos organofosforados no organismo humano são a pulmonar, devido à elevada pressão de vapor, e dérmica, por serem esses compostos lipossolúveis. A vida média do composto inalterado e de seus produtos de biotransformação, no organismo é relativamente curta. A biotransformação ocorre através da ação de enzimas oxidases, hidrolases e transferases, principalmente hepáticas (Centro Panamericano de Ecología Humana y Salud, 1991).

Os inseticidas organofosforados inibem o centro esterásico da acetilcolinesterase, incapacitando a mesma para exercer sua função, ou seja, desdobrar a acetilcolina em colina e ácido acético. Na presença do organofosforado, a enzima é fosforilada e provoca um acúmulo de acetilcolina nas fibras nervosas pós-ganglionares parassimpáticas (receptores muscarinicos), nas fibras simpáticas e parassimpáticas e nervos motores somáticos (receptores nicotínicos) e no cérebro (receptores da acetilcolina). Como conseqüência, os individuos intoxicados apresentam um quadro clínico neurológico (central e periférico) que pode evoluir ao óbito por paralisia dos músculos respiratórios e inibição dos centros do sistema nervoso central que controlam a respiração (Centro Panamericano de Ecología Humana y Salud, 1991; Larini, 1993; Stine e Brown, 1996). 
Outras manifestações clínicas associadas à exposição aos inseticidas organofosforados são a sindrome neurotóxica intermediária, que pode ocorrer no periodo de 24 a 96 horas depois dos sinais e sintomas colinérgicos agudos, e a sindrome neurotóxica tardia, resultante da inibição de uma carboxiesterase neuronal não especifica. Quando instaladas, o prognóstico é grave, a mortalidade elevada e a recuperação dos sobreviventes é lenta (Larini, 1993).

A determinação rotineira da atividade sangüinea das colinesterases tem sido freqüentemente aplicada em trabalhadores com possibilidade de exposição aos organofosforados. Após exposição única dos individuos ao composto, a atividade da colinesterase plasmática tende à recuperação mais rapidamente do que a eritrocitária, sendo que, após intoxicação severa, a atividade da plasmática é recuperada por volta de 45 dias e a da eritrocitária em 100 dias, tempo correspondente à síntese hepática de novas enzimas e à sintese de novos eritrócitos, respectivamente (Murphy, 1986).

A colinesterase eritrocitária ou acetilcolinesterase, geralmente, constitui um recurso mais especifico e sensivel do que a colinesterase plasmática ou pseudocolinesterase, pois apresenta, na maioria dos casos, correlação com a severidade do quadro clínico. Porém, dependendo do composto, a inibição relativa da pseudocolinesterase plasmática e da acetilcolinesterase eritrocitária pode diferir. Compostos como malation, diazinon e diclorvós inibem primeiramente a colinesterase plasmática, fazendo deste parâmetro o mais sensivel indicador de exposição, porém essa inibição pode não estar bem correlacionada com o quadro clínico apresentado (Murphy, 1986). 
Há, ainda, que ser ressaltado o fato de que existem limitações para - uso desses indicadores, decorrentes das variações individuais, tais como: sexo, idade, raça, estado nutricional, gravidez, consumo de álcool, condição genética, problemas hepáticos e renais, além da exposição a outras substáncias e da sazonalidade (Centro Panamericano de Ecología Humana y Salud, 1991). Esses indicadores, portanto, não devem ser utilizados isoladamente, mas associados à história ocupacional e clínica dos individuos, e, preferencialmente, os valores laboratoriais de referência devem ser os do próprio indivíduo antes da exposição, ou, caso seja impossivel obtê-los, valores de referência para a população da região devem ser estabelecidos.

Em virtude do uso elevado dos inseticidas organofosforados na agricultura e da disponibilidade de métodos confiáveis para a detecção de seus residuos, é prática comum incluí-los em trabalhos de controle e monitoramento de alimentos; como conseqüência, existem mais informações sobre a exposição humana em geral a esses produtos presentes em alimentos. A literatura está repleta de métodos multiresíduos para a deteç̧ão dessa classe de praguicidas, e a escolha da melhor técnica parece depender, sobretudo, da estrutura disponivel de cada laboratório.

\subsubsection{INSETICIDAS ORGANOCLORADOS}

Os organoclorados são produtos derivados de hidrocarbonetos policlorados, como diclorodifeniletanos (DDT), ciclodienos (aldrin) e 
hexaclorociclohexano (lindano), com pronunciada lipossolubilidade e grande estabilidade química e ação residual (Murphy, 1986; Larini, 1993).

São amplamente absorvidos pelas vias oral, respiratória e dérmica, apresentando uma distribuição desigual no organismo, com facilidade de atravessar as barreiras hematoencefálica e placentária. O armazenamento no tecido adiposo do organismo animal é considerável, assim como a eliminação láctea (Larini, 1993; Stine e Brown, 1996).

A apolaridade e a lipossolubilidade caracteristicas dos inseticidas organoclorados favorecem a sua bioconcentração. A bioconcentração de um toxicante é a proporção da sua concentração em um determinado organismo em relação a sua concentração no ambiente (Stine e Brown, 1996). Assim, semelhantemente ao que ocorre a outros toxicantes ambientais lipofilicos, os niveis de DDT em espécies aquáticas pequenas são baixos, em torno de $1 \mathrm{ppm}$, atingindo, porém, niveis elevados (20 a 25 ppm) em organismos do topo da cadeia alimentar. Esses niveis são suficientes para, por exemplo, interferir na formação da casca do ovo de pássaros carnivoros, à medida que reduzem drastricamente o número de filhos viáveis na população afetada. O DDT, composto biologicamente ativo, é biotransformado em produtos também biologicamente ativos e apenas lentamente são convertidos em formas inativas (Stine e Brown, 1996).

A resistência à degradação e a capacidade bioacumulativa são responsáveis pelo impacto no meio ambiente e na saúde. Os organoclorados têm maior chance de penetrar nas cadeias alimentares e permanecer por tempo indeterminado no meio ambiente e no organismo humano (Murphy, 1986; Zambrone, 1986; Stine e Brown, 1996). 
Os inseticidas organoclorados interferem na transmissão axônica do impulso nervoso, comprometendo a função do sistema nervoso central e autônomo, resultando em alteração de comportamento, distúrbios sensoriais, do equilibrio, da atividade muscular involuntária e depressão dos centros vitais, particularmente da respiração. Em casos de intoxicação aguda, após duas horas, surgem os sintomas neurológicos: hiperexcitabilidade, parestesia na língua ou nos lábios, também evidente nos membros inferiores, desassossego, desorientação, fotofobia, cefaléia persistente, fraqueza, vertigem, alteraçōes do equilibrio, tremores, ataxia, depressão central severa e coma. As alterações do eletroencefalograma podem perdurar por seis meses após a intoxicação. Caso ocorra absorção respiratória, podem ocorrer sintomas especificos, como tosse, rouquidão, edema pulmonar, irritação laringo-traqueal, rinorréia, broncopneumonia, bradipnéia, hipertensão, taquicardia, arritmias. As principais manifestações da intoxicação crônica são: atrofias musculares, paralisias, discrasias sangüineas diversas, inclusive aplasia medular, além da perda do apetite, hepatomegalia, lesões hepáticas com alterações das transaminases e fosfatase alcalina, lesões renais, pneumonia química e dermatites (Murphy, 1986).

Dieldrin e clordano foram registrados para muitos usos na agricultura, e o clordano foi o principal agente utilizado contra a formiga branca nos últimos 30 anos. Contudo, o registro desses compostos e de muitos outros inseticidas ciclodienos foi cancelado pela Environmental Protection Agency - EPA, devido à ação residual apresentada e à suspeita de carcinogenicidade. Atualmente, estudos mostram que tanto o dieldrin como o clordano bloqueiam o receptor GABA (ácido gama-aminobutírico), 
aminoácido neurotransmissor produzido pelos neurônios (Hoffmann, 1996 Stine e Brown, 1996).

A estrutura química do mirex, produto comprovadamente carcinogênico, permite que praticamente não ocorra biotransformação e haja acumulação nos tecidos adiposos, devido a combinação de lipossolubilidade e um processo de biotransformação muito lento. O lindano, derivado do benzeno, interfere no funcionamento do sangue no organismo, à medida que age na medula óssea. Danos na medula óssea podem provocar pancitopenia, uma diminuição do número de células vermelhas e brancas e plaquetas; danos severos ou destruição da medula impedem a produção de novas células, o que caracteriza a anemia aplástica (Stine e Brown, 1996).

Modificações genéticas, teratogenicidade e carcinogenicidade direta são aceitas para alguns organoclorados, como aldrin, dieldrin e clordano, porém outros compostos agem como promotores no processo cancerígeno (Zambrone, 1986; Hoffmann, 1996;). Estudos recentes, apesar de não conclusivos, levantam a possibilidade do envolvimento desses compostos com o câncer de mama (Hoffmann, 1996).

A partir da década de 70 , inúmeros paises passaram a restringir o uso dos organoclorados na agricultura, o que ocorreu em 1974 nos Estados Unidos. No Brasil, a proibição só veio em 1985, através da Portaria $N^{\circ} 329$, a qual, porém, abre exceções à restrição. A Lei $7.802 / 89$ exigiu uma reavaliação do registro de todos os praguicidas organoclorados (Andrade, 1995).

Assim como para os organofosforados, os métodos analiticos para resíduos de organoclorados em alimentos e amostras biológicas estão bem 
estabelecidos e, normalmente, são os primeiros a serem implementados nos laboratórios que se propõem o controle de alimentos e monitoramento de exposição a praguicidas.

\subsubsection{FUNGICIDAS DITIOCARBAMATOS}

Os fungicidas ditiocarbamatos podem ser divididos em duas classes: os dimetilditiocarbamatos (DMDCs), tendo como modelo ferbam, ziram, tiram, e os etilenobisditiocarbamatos (EBDCs), como maneb, zineb e mancozeb. Com exceção do tiram, todos esses produtos são derivados organometálicos (WHO, 1988).

O uso dos ditiocarbamatos é bem conhecido desde 1934 no controle de um grande número de espécies pertencentes a grupos taxonomicamente diferentes, como bactérias, fungos, nematóides e moluscos. Eles possuem propriedades fungicida, inseticida e herbicida e são utilizados, também, como repelentes de roedores para proteger plantas novas. Além de serem aplicados na agricultura, os ditiocarbamatos são empregados na indústria como aceleradores da vulcanização de vários elastômeros e antioxidantes em borracha, no controle do crescimento de alga, bactéria e fungo em sistemas de refrigeração, como reagentes na análise de metais pesados, como quelantes de metais no tratamento de efluentes e na medicina humana, por exemplo, em caso de intoxicação por niquel (Van Leeuwen e col., 1985a; Krause, 1989; Kurttio e col., 1992; Meiring e De Jong, 1994).

Como regra geral, os ditiocarbamatos podem ser absorvidos pelo organismo através da pele, das mucosas e do trato respiratório e 
gastrointestinal. O contato regular aos compostos pode causar alterações funcionais nos sistemas nervoso e hepático. A exposição dérmica pode induzir dermatite de contato e alguns desses compostos podem induzir sensibilização (WHO, 1988).

Os ditiocarbamatos não são considerados fitotóxicos e as doses letais calculadas para animais são consideradas altas. As $\mathrm{DL}_{50}$ para rato são $1.400,4.600,>5.200 \mathrm{e}>8.000 \mathrm{mg} / \mathrm{kg}$ para ziram, maneb, zineb e mancozeb, respectivamente (WHO, 1988; Mestres e Mestres, 1991). Estudos de efeitos crônicos em animais permitiram estabelecer niveis de não efeito (NOEL) e ingestão diária aceitável (IDA), conforme mostra a Tabela 9 (Mestres e Mestres, 1991).

Tabela 9 - Niveis de não efeito (NOEL) e ingestão diária aceitável (IDA) estabelecidos para alguns fungicidas ditiocarbamatos (Mestres e Mestres, 1991).

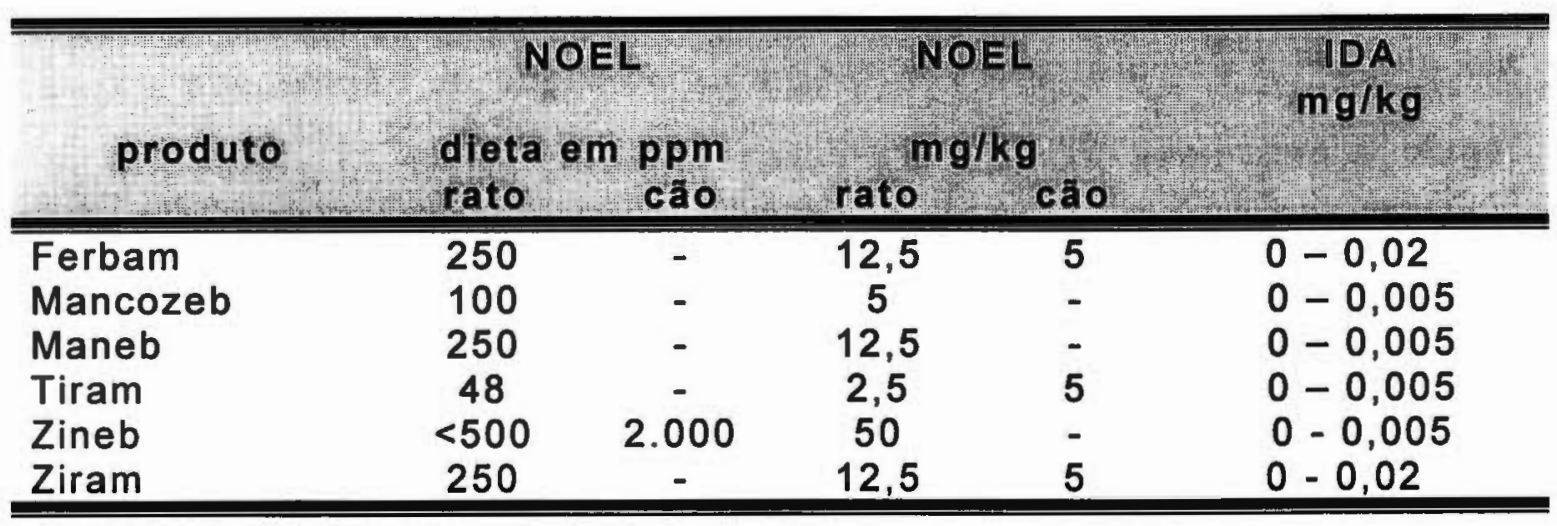

Os compostos do grupo dos EBDCs são degradados ou biotransformados a outros produtos, dentre eles a etilenotiuréia (ETU), 
com alta hidrossolubilidade e possiveis efeito tóxicos associados (WHO, 1988).

\subsubsection{Os etilenobisditiocarbamatos (EBDCs) e etilenotiuréia (ETU)}

\section{- Uso e ocorrência}

Os etilenobisditiocarbamatos (EBDCs) representam uma das classes de fungicidas mais antigas e usadas do mundo, reunindo um relativo baixo custo e amplo espectro de ação contra fungos e bactérias. Esses produtos já foram utilizados para controlar cerca de 400 agentes patogênicos em mais de 70 culturas, incluindo maçã, tomate, batata, banana, milho e trigo. Estima-se que mais de 65 milhões de quilos por ano ainda sejam usados em todo o mundo (Van Leeuwen e col., 1985a).

Agricultores americanos consideram o seu uso de extrema importância para a garantia de uma boa colheita, acreditam ser a única alternativa para algumas culturas, como tomate, pimenta doce e alface, pois a associação do cobre com os EBDCs é aceita como a medida eficaz contra certas bactérias (Frakes, 1988). Os EBDCs, em especial Maneb e Zineb, são de amplo uso no controle de fungos comuns nas plantações de pepino, pimenta e tomate, cultivados em estufa fria no Egito (Walash e col., 1993). No estado americano de Maine, o mancozeb e o maneb são os produtos de maior uso em culturas de batata, maçã, brócolis e feijão (Frakes, 1988, Neil e Williams, 1990); também é grande seu uso na cultura de berinjela, na India (Kumar e Agarwal, 1992), e de tomate para processamento, na Malásia (Cheah, 1985). Em 1987, mais de 2.300 
toneladas de EBDCs foram utilizadas na Holanda, incluindo o maneb, o mancozeb, o nabam e o zineb (Van der Poll e col., 1993).

No Brasil, seu uso também é bastante disseminado e representa o principal produto contra fungos. Conforme dados da Associação Nacional de Defensivos Agrícolas (ANDEF, 1995/1996), o consumo aparente de fungicidas deve representar cerca de $40 \%$ do consumo total de praguicidas, sendo cerca de $60 \%$ pertencentes aos etilenobisditiocarbamatos.

O fungicida mancozeb tem sido bastante utilizado nas culturas de tomate de mesa e industrial, em diferentes regiōes do Estado de Pernambuco. Nas plantações de tomate industrial do perímetro irrigado do Vale do São Francisco, por exemplo, o mancozeb representa $30 \%$ do total de praguicidas em uso naquela região, quando considerada a quantidade de principio ativo de cada um dos 53 praguicidas listados pelos usuários do Projeto Senador Nilo Coelho.

Os EBDCs são produtos instáveis na presença de umidade, oxigênio ou em fluidos biológicos (Hogendoorn e col., 1991; Lehotay e Kisová, 1993). Decompõem-se e provocam a formação de, entre outros produtos, etilenotiuréia (2-imidazolidinethione ou ETU), a qual é relativamente estável (WHO,1988).

A degradação dos EBDCs pode ocorrer durante a manufatura ou o armazenamento da fórmula fungicida, na cultura após o tratamento e, principalmente, durante o processamento do alimento. Prova disso é o fato de a ETU ser raramente encontrada como tal após o tratamento da cultura com EBDCs, mas ser detectada quando frutas e vegetais tratados são cozidos. Portanto, para evitar residuos de ETU em produtos acabados, é 
necessário eliminar a presença de precursores nos alimentos crus, como frutas e vegetais (Hogendoorn e col., 1991; Mestres e Mestres, 1991).

Segundo Bottomley e col.(1985), a preocupação no que se refere à concentração de ETU como conseqüência do processamento do alimento parece procedente. Os procedimentos empregados, em particular o calor, podem favorecer a transformação de residuos de EBDCs, elevando o nivel de ETU no alimento processado, chegando a valores bem mais altos do que os encontrados no alimento cru. Foi registrado um aumento de ETU de $45,6 \%$ em berinjela, $20 \%$ em espinafre e $34 \%$ em maçã, em amostras adicionadas de mancozeb, resultante do cozimento a $92-97^{\circ} \mathrm{C}$ por 25 minutos (Kumar e Agarwal, 1991).

Após a aplicação do mancozeb, foi observado que a ETU pode ser continuadamente gerada pela degradação do fungicida e que existe a possibilidade de sua presença ainda no produto a ser aplicado na cultura (Lehotay e col., 1992). A relação entre a quantidade de fungicida aplicado em diferentes culturas, como tomate, alface e pimentão, e a formação de ETU tem sido demonstrada por vários autores (Pelegrí e col., 1988; Kumar e Agarwal, 1992).

Segundo Lehotay e col. (1992), o nível de ETU diminui vagarosamente, apresentando uma meia vida de cerca de 6 dias. Aparentemente, sua degradação é mais rápida do que a sua formação por degradação do mancozeb (Lehotay e col., 1992). No entanto, segundo relatório publicado por Neil e Williams (1990), a ETU é bastante persistente no meio ambiente, tendo sido encontrada em água de poço após 6 meses da última aplicação de mancozeb. 
Apesar de não ser considerado o fator mais critico na exposição à ETU, existe, também, uma certa preocupação no controle de sua presença em formulaçōes de fungicidas EBDCs, como uma impureza ou um produto de degradação. Nesse caso, a concentração de ETU depende do tempo entre a fabricação e o uso, das condições de estocagem, umidade e temperatura (Camoni e col., 1988; Hogendoorn e col., 1991). De uma maneira geral, espera-se que sua concentração não exceda $0,5 \%$ no produto final, o que nem sempre ocorre (Camoni e col. , 1988).

A Figura 4 mostra um mecanismo proposto para a degradação oxidativa dos EBDCs: a ETU é uma conseqüência da quebra do dissulfeto de etilenotiuram (ETD), o qual é formado pela oxidação de EBDC (Hogendoorn e col., 1991; Mestres e Mestres,1991).

A Comissão de Resíduos de Praguicidas da Comissão de Química Aplicada da IUPAC (IUPAC, 1977) publicou um relatório de ocorrência de ETU resultante do uso de fungicidas da classe dos EBDCs. Desse documento constam revisōes técnicas da química da ETU, da dinâmica e das transformaçōes dos residuos de ETU no ambiente, animal, alimento e o efeito do cozimento e do processamento dos EBDCs.

A relativa estabilidade e, sobretudo, a alta polaridade da ETU têm sido motivo de preocupação em muitos paises, no que se refere à possibilidade de ocorrência em água subterrânea, de rios e potável, em áreas onde os EBDCs são utilizados para proteção da lavoura (Hogendoorn e col., 1991; Van der Poll e col., 1993). 
(1)

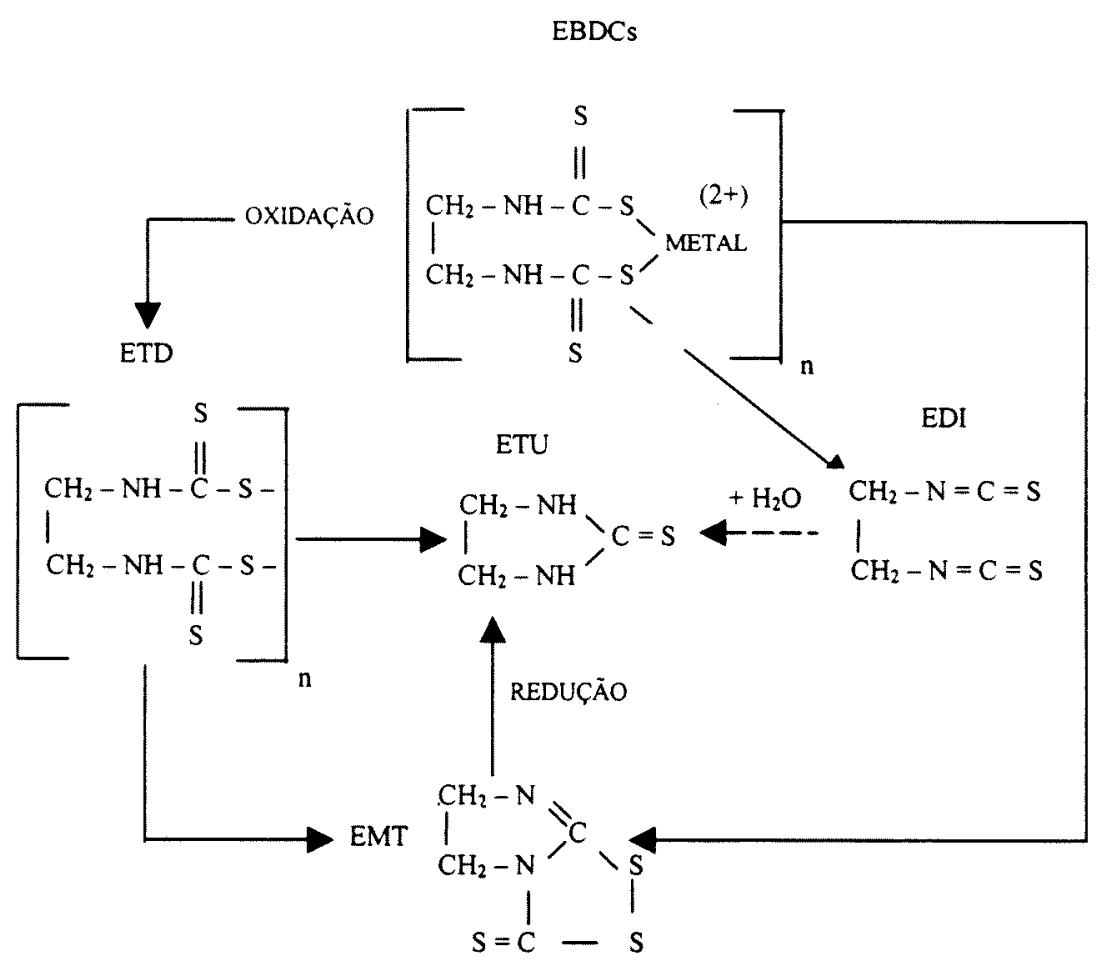

(2)

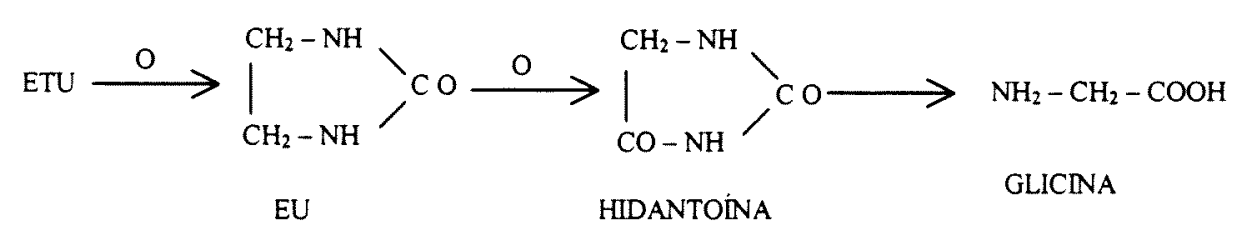

ETD: etilenoditiocarbamato; EDI: etilenodiisotiocianato; ETM: etilenotiuram; EU: etilenouréia

Figura 4 - Possível mecanismo oxidativo de degradação dos EBDCs (1) e fotooxidação da ETU (2). 
A contaminação generalizada por ETU do vulnerável suprimento de água subterrânea pelo uso de praguicidas tornou-se prioridade para a Agência Americana de Proteção Ambiental (USEPA) no início dos anos 80 . Em 1983, o Congresso dos Estados Unidos encarregou a USEPA de monitorar a água potável e os reservatórios do pais, para o estabelecimento do grau de contaminação por esse produto (Longbottom e col., 1993). Essa iniciativa gerou estudos colaborativos cujo objetivo principal foi determinar e comparar as médias de recuperação e precisão para a determinação da ETU em água reagente e água potável e contou com a participação de 20 laboratórios americanos.

A persistência e o movimento no solo do fungicida mancozeb e de seus produtos de degradação também foram estudados por Calumpang e col. (1993), com o objetivo de avaliar o potencial de contaminação de lençóis freáticos. Os autores concluíram que tanto o mancozeb como a ETU, se aplicados dentro das boas práticas agricolas, não devem contaminar águas subterrâneas. Fazem ressalvas, porém, visto que o comportamento observado depende das condições do solo, que apresenta rápida degradação em condições tropicais.

De fato, na região estudada, a meia vida do mancozeb no solo, por exemplo, varia de 2 a 14 dias e, para o maneb e o zineb, está entre 23 a 56 dias (Kumar e Agarwal, 1992; Calumpang e col., 1993; Lehotay e Kisová, 1993). Em estudos realizados por Calumpang e col. (1993), demonstrou-se que a ETU atinge a profundidade de, no máximo, $8 \mathrm{~cm}$ do solo após 14 dias da aplicação do mancozeb, e apenas $2 \%$ da ETU inicial foi detectada após 21 dias de aplicação do produto. 
Um dos poucos trabalhos realizados no Brasil relacionados com os residuos de fungicidas EBDCs estuda a presença de residuos de ditiocarbamatos, na forma inalterada, em 466 amostras de vegetais e frutas comercializadas na cidade do Rio de Janeiro (Reis e Caldas, 1991). Observou-se que $63 \%$ das amostras acusaram a presença de residuos, estando $24 \%$ delas com concentrações superiores ao limite legal estabelecido. Os principais produtos com elevado nivel residual foram alface, cenoura e tomate, com $50 \%, 47,4 \%$ e $38,2 \%$ acima do limite, respectivamente. Um outro trabalho, apresentado resumidamente em reunião científica, refere-se à concentração da própria ETU, presente em niveis elevados em uvas coletadas no Rio Grande do Sul (Dal Piva e col., 1995).

A literatura internacional, por outro lado, oferece uma infinidade de resultados analiticos de residuos de fungicidas ditiocarbamatos e ETU em alimentos, como o pepino (Lehotay e Kisová, 1993), a uva (Pellacani e col., 1993), a alface, o tomate e o pimentão (Pelegri e col., 1988), o tomate e derivados (Bolzoni e col., 1993), e no meio ambiente, como o solo (Calumpang e col., 1993) e a água (Hogendoorn e col., 1991; Van der Poll e col., 1993).

Acredita-se, porém, que, quando aplicados corretamente, dentro da boa prática agricola, e obedecidos os intervalos de segurança entre a última aplicação e a colheita, os niveis de residuos remanescentes nos alimentos não deverão apresentar valores maiores do que os permitidos pela legislação para uma grande parte das culturas testadas. Foi observado, também, que uma simples lavagem com água e sabão em 
alguns produtos, como o tomate, por exemplo, pode reduzir até $70 \%$ do residuo (Cheah, 1985; Mestres e Mestres, 1991; EPA,1992).

Mestres e Mestres (1991) observaram que, sendo obedecido um periodo de carência de 14 dias após a aplicação do EBDC em vegetais, os niveis residuais estariam dentro do limite permitido, podendo haver variações, contudo, nas diferentes folhas de um mesmo vegetal. No entanto, Ankumah e Marshall (1984) demonstraram que residuos de ETU são estáveis em suco de tomate, tendo sido detectados 76 a $91 \%$ após 12 semanas da aplicação. Existem estudos nos quais foi comprovada a remoção de residuos de ETU e EBDCs em tomate e feijão, após o uso de solução diluída de hipoclorito de sódio (Marshall, 1982).

Em 1974, a Comissão de Residuos de Praguicidas da FAO/WHO estabeleceu níveis máximos de ETU para 11 diferentes produtos (JMPR, WHO/FAO,1975) e a Comissão do Codex Alimentarius, em 1986, estabeleceu a IDA para ETU de $0,002 \mathrm{mg} / \mathrm{kg}$ de peso corpóreo/dia (Mestres e Mestres, 1991).

Nos Estados Unidos, em 1991, a EPA propôs o cancelamento do uso dos EBDCs em 45 tipos de culturas, incluindo vegetais, e outros países começaram a se preocupar com as conseqüências do uso dos EBDCs, como a Alemanha e a Grā Bretanha. No entanto, devido ao interesse econômico envolvido, foi grande a reação da indústria, de grupos ativistas e organizações de agricultores americanos contra a medida, o que gerou a publicação de uma grande quantidade de artigos cientificos ou não e deu inicio a uma situação polêmica no que se refere à relação risco/benefício advinda dessa prática. 
A decisão final, divulgada em 1992 pela EPA, manteve a proibição para apenas 11 culturas, chamando a atenção, porém, para o estabelecimento de algumas condiçōes, como o uso de roupas de proteção, um maior intervalo de carência e uma diminuição das aplicações. Um fato decisivo para a liberação do produto foi o intenso estudo, estimado em 10 milhões de dólares, realizado nos Estados Unidos, durante o qual 6.000 amostras de alimentos foram analisadas. Ficou comprovado que os niveis residuais de EBDCs encontrados nos alimentos estavam muito abaixo daqueles estimados pela EPA em 1989, quando foi proposto - cancelamento do seu uso em um grande número de culturas (American Vegetable Grower, 1992; EPA, 1992). A decisão de dar continuidade à aplicação do composto foi apoiada pela Associação Nacional dos Processadores de Alimento dos Estados Unidos, a qual estimava que o beneficio do uso dos EBDCs era da ordem de 260 a 500 milhões de dólares (American Vegetable Grower, 1992).

Contudo, a reação de grupos ambientalistas e ativistas da comunidade americana contra o uso de praguicidas foi imediata, levantando suspeitas sobre a decisão oficial da EPA. A principal justificativa era baseava-se no fato de a EPA ter aceito dados e informaçōes fornecidos por fabricantes de EBDCs, através do grupo chamado "EBDC/ETU Task Force", composto por representantes de quatro empresas comerciais (American Vegetable Grower, 1992; EPA, 1992).

\section{- Efeitos tóxicos}

São inúmeros os trabalhos citados na literatura atual sobre os possiveis efeitos tóxicos da ETU, porém este ainda é um assunto cercado 
de grande polêmica. Assim, artigos científicos de resultados contraditórios estão disponiveis na literatura especializada, por exemplo: ora mostra-se que o zineb não possui efeito citotóxico in vitro e a ETU parece não ser capaz de exercer efeitos mutagênicos (Perocco e col., 1995), ora danos genéticos são observados em relação aos mesmos compostos (Franekié e col., 1994).

Comprovadamente, a ETU tem a capacidade de induzir tumor na tiróide de roedores e no fígado de camundongo (Trivedi e col., 1993; Yoshida e col., 1993; Yoshida e col., 1994; Elia e col., 1995; Perocco e col., 1995). Parece claro que a indução do tumor da tireóide ocorre por via não-genotóxica, porém o papel da ETU na indução do tumor de fígado permanece não elucidado (Elia e col., 1995). Sabe-se, no entanto, que o figado e a tiróide são locais de acúmulo de ETU no organismo (Nebbia e col., 1991).

Dearfield (1994), em trabalho de revisão sobre a genotoxicidade da ETU, concluiu que, embora a ETU não seja um potente agente, ela é um composto fracamente genotóxico, e sugeriu novos estudos para a elucidação do seu potencial genotóxico. Dentre os efeitos genotóxicos associados à ETU, citados em seu trabalho, estão mutações genéticas e aberrações na estrutura de cromossomas. Segundo o mesmo autor, suas conclusões coincidem com a posição final do Programa de Praguicidas da Agência Americana de Proteção Ambiental (EPA, 1992).

Esses dados são conflitantes com relatórios de autoridades independentes, cujas colocações apontam a ETU como um agente não genotóxico para mamiferos (IARC, 1987; NIH, 1992; JMPR, FAO/WHO, 1994;). Esta última posição foi endossada por Elia e col. (1995), que, ao 
estudarem os possiveis efeitos mutagênicos da ETU, não observaram efeito genotóxico em sistemas mamiferos, o que sugere que a ETU induz tumor hepático em camundongo por um mecanismo não-genotóxico.

A neoplasia de tiróide de roedores induzida pela ETU está bem caracterizada, sendo considerada típica de agentes goitrogênicos, cuja administração crônica interrompe a axis pituitária-tireóide. A ETU inibe a peroxidase tireóidica, provocando uma diminuição na circulação dos níveis de hormônio da tiróide e um aumento compensatório de secreção pela pituitária do hormônio estimulador da tiróide, TSH (Elia e col., 1995).

No sistema aquático, os etilibisditiocarbamatos mostraram ação citóxica após um periodo de curta exposição para bactérias, algas verdes, crustáceos e peixes (Van Leeuwen e col., 1985a; Van Leeuwen e col., $1985 b)$.

A ETU foi incluida pelo método da Agência Internacional para Pesquisa em Câncer (IARC, 1987) no grupo de "possiveis compostos carcinogênicos para humanos", grupo 2B. Segundo Meiring e De Jong (1994), existe suficiente evidência animal, mas limitada ou insuficiente evidência de carcinogenicidade em seres humanos disponivel.

São descritos casos de alteraçōes temporárias no sistema nervoso central, diarréia e dano agudo renal em trabalhadores expostos à ETU, e a roupa parece ter um papel importante na proteção à exposição (Kurttio e col., 1990). Em 1985, foi publicado um caso em que o fungicida mancozeb induziu dermatite de contato alérgica, caracterizada como dermatite semelhante à pelagra, em um trabalhador rural de 68 anos (Lisi e Caraffini, 1985); os autores chamam a atenção para o aspecto clinico não 
usual e para o fato raro de aparecimento de dermatite de contato em área de vitiligo.

Durante a exposição ocupacional, tanto os EBDCs como a ETU podem ser absorvidos pelos pulmões, trato gastrintestinal e pele. A administração de mancozeb em animais de laboratório mostrou que a maior parte da dose é eliminada inalterada pelas fezes e uma pequena quantidade $(15,5 \%)$ é biotransformada e aparece na urina na forma de ETU, etilenouréia e N-acetiletilenodiamina. Em virtude da biotransformação dos EBDCs no organismo, a ETU urinária tem sido mencionada como indicador da exposição a essa classe de fungicidas (Kurttio e col., 1990; Kurttio e Savolainen, 1990; Canossa e col., 1993).

As principais preocupações associadas à ETU são, portanto, a exposição ocupacional na indústria e agricultura, os riscos relacionados com residuos de ETU no alimento e o impacto ambiental.

Observa-se que, em vários paises, estão sendo discutidos os possiveis niveis residuais tóxicos para a ETU e sua relação com o valor médio ao qual suas populaçōes estão expostas. Entretanto, no Brasil, não existem estudos com dados analíticos que permitam uma avaliação do grau de exposição ocupacional e da população em geral à ETU ou mesmo uma definição dos alimentos com maiores niveis residuais.

\section{- Revisão dos métodos analíticos}

Em virtude da importância econômica dos fungicidas EBDCs na prática agricola e dos riscos para o homem e meio ambiente associados aos residuos de ETU, são vários os estudos analiticos desenvolvidos com 
o objetivo de detecção de resíduos de ETU em diferentes matrizes (Tabela 10).

Tabela 10 - Principais trabalhos analíticos, citados na literatura, relativos à deteç̧ão de ETU.

\begin{tabular}{|c|c|c|c|c|c|}
\hline $\begin{array}{c}\text { autor, } \\
\text { ano }\end{array}$ & pais & Identiflcagao & matrlz & 14. & $\begin{array}{l}\text { recupes } \\
\text { racao }\end{array}$ \\
\hline $\begin{array}{c}\text { Caccialanza } \\
\text { e col.. } \\
1980 / 1981\end{array}$ & Itália & HPLC/UV & $\begin{array}{c}\text { tomate, maçă } \\
\text { uva, vinho }\end{array}$ & - & $92-97 \%$ \\
\hline $\begin{array}{l}\text { Massey e } \\
\text { col., } 1982\end{array}$ & $\begin{array}{c}\text { Gră- } \\
\text { Bretanha }\end{array}$ & HPLC/UV & cerveja & $10 \mathrm{ppb}$ & $62-75 \%$ \\
\hline $\begin{array}{c}\text { Nitz e col. } \\
1982\end{array}$ & Alemanha & CG/DFC & $\begin{array}{l}\text { cerveja, uva, } \\
\text { lúpulo }\end{array}$ & $5,0 \mathrm{ppb}$ & $85-95 \%$ \\
\hline $\begin{array}{c}\text { Greve e } \\
\text { Herbold, } \\
1983\end{array}$ & Bélgica & HPLC/UV & $\begin{array}{c}\text { alho, } \\
\text { chicória }\end{array}$ & $\begin{array}{c}0,01-0,02 \\
\text { ppm }\end{array}$ & $90 \%$ \\
\hline $\begin{array}{c}\text { Matsova e } \\
\text { col.,1984 }\end{array}$ & Eslováquia & CGIDIC-DCE & $\begin{array}{c}\text { uva, vinho, } \\
\text { trigo }\end{array}$ & $\underset{\mathrm{ppb}}{0,02-1,0}$ & $33-92 \%$ \\
\hline $\begin{array}{c}\text { Krause e } \\
\text { Wang, } 1988\end{array}$ & E.U.A. & HPLC/eletroquímico & $\begin{array}{c}\text { maçă, } \\
\text { batata, } \\
\text { espinafre }\end{array}$ & $0,1 \mathrm{ppm}$ & $89-109 \%$ \\
\hline $\begin{array}{l}\text { Kurttio e } \\
\text { col., } 1988\end{array}$ & Finlândia & HPLC/UV-DAD & $\begin{array}{c}\text { urina, filtros } \\
\text { ambientais }\end{array}$ & $\begin{array}{c}0,2 \text { ppb } \\
\text { (para urina) }\end{array}$ & $79-94 \%$ \\
\hline Krause, 1989 & E.U.A. & HPLC/eletroquimico & $\begin{array}{c}\text { tomate, } \\
\text { feijăo, alface }\end{array}$ & $\begin{array}{c}0,01-0,02 \\
\mathrm{ppm}\end{array}$ & $92 \%$ \\
\hline $\begin{array}{c}\text { Moza e } \\
\text { Hustert. } \\
1989\end{array}$ & Alemanha & HPLC / UV & água, solo & $0.1 \mathrm{ppm}$ & - \\
\hline $\begin{array}{l}\text { Rogerse } \\
\text { col., } 1989\end{array}$ & E.U.A. & HPLC/UV & leite, carne & - & - \\
\hline $\begin{array}{l}\text { Doerge e } \\
\text { Yee, } 1991\end{array}$ & Havaf & HPLC/eletroquímico & $\begin{array}{c}\text { água, } \\
\text { mamáo, } \\
\text { banana }\end{array}$ & $5,0 \mathrm{ppb}$ & $80-93 \%$ \\
\hline $\begin{array}{l}\text { Hogendoorn } \\
\text { e col., } 1991\end{array}$ & Holanda & HPLCIUV & Água & $1,0 \mathrm{ppb}$ & $96 \%$ \\
\hline $\begin{array}{c}\text { Kobayashi, } \\
1992\end{array}$ & Japăo & HPLC / UV & pepino & - & $87,2 \%$ \\
\hline $\begin{array}{l}\text { Kurttio e } \\
\text { col., } 1992\end{array}$ & Finlândia & HPLC / DSM & urina & $0,2 \mathrm{ppb}$ & - \\
\hline $\begin{array}{l}\text { Lehotaye } \\
\text { col., } 1992\end{array}$ & Eslováquia & HPLC / UV & $\begin{array}{c}\text { tomate, } \\
\text { maçâ, batata }\end{array}$ & $0,1 \mathrm{ppm}$ & $>80 \%$ \\
\hline $\begin{array}{c}\text { Liska e col., } \\
1992\end{array}$ & Holanda & HPLC / DAD & Agua & - & - \\
\hline
\end{tabular}




\section{Continuação da Tabela 10.}

\begin{tabular}{|c|c|c|c|c|c|}
\hline $\begin{array}{l}\text { Bolzonie } \\
\text { col., } 1993\end{array}$ & Itália & $\begin{array}{c}\text { HPLC/eletroquímico } \\
\text { CG/DFC }\end{array}$ & $\begin{array}{c}\text { tomate e } \\
\text { derivados, } \\
\text { frutas }\end{array}$ & $3.0 \mathrm{ppb}$ & $68-87 \%$ \\
\hline $\begin{array}{l}\text { Longbottom } \\
\text { e col. } 1993\end{array}$ & E.U.A. & $C G / D N P$ & água & $2,0 \mathrm{ppb}$ & $85-98 \%$ \\
\hline $\begin{array}{c}\text { Van der Poll } \\
\text { e col.. } \\
1993\end{array}$ & Holanda & $\begin{array}{l}C G / D N P \\
C G / D S M\end{array}$ & água & $0.1 \mathrm{ppb}$ & $70-72 \%$ \\
\hline $\begin{array}{l}\text { Walash e } \\
\text { col., } 1993\end{array}$ & Egito & $\begin{array}{c}\text { espectrofotometria } \\
\text { no visivel }\end{array}$ & $\begin{array}{l}\text { tomate, } \\
\text { pepino, } \\
\text { pimenta }\end{array}$ & $10 \mathrm{ppm}$ & $98,4 \%$ \\
\hline $\begin{array}{c}\text { Maruyama } \\
1994\end{array}$ & Japão & HPLC/eletroquímico & $\begin{array}{l}\text { tomate, } \\
\text { pepino }\end{array}$ & $0,01 \mathrm{ppm}$ & $83-84 \%$ \\
\hline $\begin{array}{l}\text { Meiring e De } \\
\text { Jong, } 1994\end{array}$ & Holanda & CG / DSM & água & $0,05 \mathrm{ppb}$ & $80 \pm 20 \%$ \\
\hline $\begin{array}{l}\text { Dal Piva e } \\
\text { col., } 1995\end{array}$ & Brasil & HPLC / UV & batata & - & - \\
\hline
\end{tabular}

L.Q. = Limite de quantificação; HPLC = Cromatografia liquida de alta eficiência; UV = Ultravioleta; CG = Cromatografia a gás; $D F C=$ Detetor fotométrico de chama; DIC = Detetor de ionização de chama; $D C E=$ Detetor de captura de elétrons; $D A D=$ Detetor de arranjo de diodos; $D S M=$ Detetor seletivo de massa; $D N P=$ Detetor de nitrogênio/fósforo.

Em 1984, a literatura já era rica de artigos específicos ou de revisão sobre os fungicidas EBDCs e seu produto de degradação, a ETU. Porém, segundo Bottomley e col. (1985), existiam várias razões para se proceder a uma revisão dos métodos analiticos: a) necessidade de definir quais os niveis reais de deteç̧ão da ETU em várias situações; b) carência de estudos das dificuldades relatadas por vários pesquisadores na aplicação desses métodos em outros substratos para os quais eles foram desenvolvidos; c) os artigos científicos procuravam cobrir, sobretudo, aspectos relacionados à toxicologia, ao metabolismo e ao destino no meio ambiente, o que resultava em menor consideração dos fatores analíticos. 
em camada delgada (CCD), 23 por cromatografia em fase gasosa (CG) e 11 por cromatografia liquida de alta eficiência (HPLC).

Em 1962, Jonhson e Tyler estudaram o uso de cromatografia em camada delgada (CCD) para demonstrar a presença de ETU em EBDCs. $\mathrm{Na}$ aplicação do método para amostras de tomate e suco de laranja, chamaram a atenção para possiveis erros na quantificação de ETU relatados em trabalhos anteriores. Seguiram-se vários trabalhos por CCD (Bottomley e col., 1985), nos quais foi estudada a separação do maneb e do zineb de seus produtos de degradação, os produtos de degradação dos EBDCs, a deteç̧ão de residuos de ETU em alimentos, a maior absorção do ETU pelas plantas do que por seus precursores, a fotólise e a degradação do próprio ETU na planta, entre outros aspectos. A CCD foi usada para detecção de resíduos muitas vezes em conjunção com radioisótopos. A técnica por cromatografia em camada delgada, no entanto, requer um considerável processo de purificação, pode favorecer a degradação do ETU na própria placa cromatográfica, além de apresentar precisão e limite de deteç̧ão duvidosos (Bottomley e col., 1985; Krause, 1989).

A análise por espectrofotometria de absorção na região do visivel, após a formação de um composto colorido com 2,6-dibromoquinona ou 2,6dicloroquinona, já foi citada como uma técnica simples e precisa para a quantificação da ETU. Os fungicidas maneb e zineb, na suas formas inalteradas, também seriam detectados pelo método, porém a grande desvantagem da técnica residia no limite de quantificação de 10 ppm, o que a fazia não ser indicada, portanto, para a análise residual de ETU (Walash e col., 1993). 
A cromatografia em fase gasosa (CG) é amplamente empregada para a determinação de ETU, provavelmente devido ao limite de detecção e à especificidade obtidos a partir do uso de diferentes tipos de colunas e detetores. Um grande número de técnicas foram publicadas, sobretudo na década de 80 , com a análise da ETU por CG, com coluna empacotada ou capilar, sem ou com derivação (Bottomley e col., 1985).

A análise direta de resíduos de ETU por CG, ou seja, sem derivação, apesar de mais simples, pode apresentar resultados frustrantes na análise quantitativa, em virtude da alta polaridade, da adsorção e da baixa volatilidade da ETU, o que resulta em picos assimétricos. Dessa forma, a derivação, antes da sua análise por CG, parece ser a mais recomendada (Bottomley e col., 1985; Doerge e Yee, 1991; Mestres e Mestres, 1991).

Vários autores desenvolveram técnicas de identificação da ETU por cromatografia a gás, propondo diferentes agentes de derivação (Onley e Yip, 1971; Newsome, 1972; Nash, 1975; King, 1977; Paese e Holt, 1977), as quais foram utilizadas por outros autores, com pequenas modificações (Mestres e Mestres, 1991). Todos esses procedimentos envolvem um passo múltiplo ou único (Sing e col., 1979; Matsova e col., 1984), com temperaturas elevadas, nas quais podem ocorrer decomposições da ETU (Meiring e De Jong, 1994).

Além disso, a técnica de derivação aumenta sobremaneira o tempo de análise, tornando-se inadequada para métodos de rotina. Há, ainda, a possibilidade de reação incompleta e interferência na reação de derivação por substâncias co-extraídas, o que dá margem a uma baixa ou errônea recuperação da ETU (Bottomley e col., 1985; Kuttio e col., 1988; Krause, 1989). Alguns derivados formados são instáveis sob certas condições, por 
isso devem ser analisados rapidamente, e a maioria desses compostos são voláteis, exigindo cuidados no manuseio e etapas de concentração do método, para evitar perdas por evaporação (Bottomley e col., 1985).

Segundo Krause (1989), alguns autores encontraram dificuldades na análise de residuos de ETU com derivação e posterior quantificação por cromatografia a gás, método oficial em alguns paises, obtendo resultados anômalos. A etapa de purificação para a eliminação de compostos interferentes requer grande atenção, em particular com relação àqueles presentes em amostras de alimento (Bottomley e col., 1985).

Os primeiros pesquisadores a descrever o uso da cromatografia liquida de alta eficiência (HPLC) para a análise de residuos de ETU, em 1977, desenvolveram um elaborado processo de purificação que permitia o uso da técnica sem a etapa da derivação (Onley e Yip, 1977). Posteriormente, vários outros autores estudaram essa técnica, com resultados satisfatórios. São métodos mais simples porque não necessitam de derivação, e, através dos mesmos, obtêm-se picos simétricos em colunas de fase reversa $\left(\mathrm{C}_{18}\right)$ e em fase normal $\left(\mathrm{NH}_{2}\right)$, porém, segundo Bottomley e col. (1985), na maioria das situações, não se conseguem niveis tão baixos como os obtidos por cromatografia a gás.

O detetor espectrofotométrico (UV) acoplado ao HPLC, com comprimento de onda a $240 \mathrm{~nm}$, foi o primeiro sistema testado e ainda é o indicado por vários autores (Kurttio e col., 1988; Kobayashi, 1992; Lehotay e col., 1992), porém existe uma tendência de se aceitar o detector eletroquimico como o mais adequado, devido ao aumento de seletividade e precisão apresentado (Krause, 1989; Doerge e Yee, 1991; Bolzoni e col., 1993). A absorção em torno de $240 \mathrm{~nm}$ é uma região susceptivel a 
interferentes encontrados sobretudo em amostras ambientais, o que torna o detetor eletroquímico, amperométrico ou coulométrico, bastante aceito para essa finalidade (Doerge e Yee, 1991).

Um estudo comparativo entre os métodos por CG/DSM (Detetor seletivo de massa) e HPLC/UV, realizado por Meiring e De Jong (1994), revelou que, de 20 amostras, 5 deram resultado falso-positivo por HPLC/UV. Os autores acreditam que a contaminação da amostra pode ocorrer na borracha selante do rotavapor usado para a concentração da amostra e mostraram a necessidade de confirmação dos resultados obtidos por técnicas independentes, quando se trata de análise de traços $(<0,1 \mathrm{ppb})$.

O detetor de arranjo de diodos (DAD) acoplado ao HPLC também tem sido indicado para a confirmação de resultados obtidos pelo UV, porém, para niveis menores que $1 \mathrm{ppb}$, essa técnica parece não ser suficientemente sensivel (Liska e col., 1992).

Após estudo realizado por Krause (1989), em que os resultados obtidos pelo método oficial da AOAC foram minuciosamente avaliados, 0 autor concluiu que a cromatografia liquida (HPLC) elimina a etapa de derivação, aumenta a recuperação da ETU, reduz o tempo de análise, elimina a necessidade de reagentes adicionais e resulta em um método mais seletivo. Bolzoni e col. (1993) utilizaram CG/DFC (Detetor fotométrico de chama) para a confirmação de resultados obtidos por HPLC com detetor eletroquimico; em 100 amostras analisadas, apenas 1 caso de ETU não foi confirmado pela CG/DFC, e, neste caso, o produtor diferenciava-se dos demais. 


\subsection{CONSIDERAÇŌES GERAIS SOBRE AMOSTRAGEM PARA ANÁLISE DE RESIDUOS DE PRAGUICIDAS}

Os passos envolvidos na obtenção de dados devem ser considerados, para se colocar a amostragem dentro do contexto de um processo analitico. A seqüência consiste de cinco ações maiores: 1 construção de um modelo; 2 - elaboração de um plano; 3 - coleta de amostras; 4 - performance analitica; 5 - avaliação dos resultados. O modelo define os objetivos do trabalho: população a ser estudada, substância a ser quantificada, extensão da distribuição dentro da população e nivel de precisão requerido. $O$ plano de amostragem especifica o número, o tamanho e a localização das amostras e os procedimentos para a redução das amostras a serem enviadas para o laboratório. O plano deve ser escrito detalhadamente em protocolo prévio, incluir critérios de seleção na coleta de amostras válidas e estabelecer quando uma amostra deve ser considerada estranha ao experimento e, assim, rejeitada. Devem ser incluidas, também, informações sobre procedimentos para a proteção da amostra contra contaminação antes e após a coleta, para a preservação e a marcação de informações importantes. O próximo passo é a amostragem, na qual amostras de campo são coletadas e, se necessário, subdivididas em porçōes para os testes. Em seguida, vem a análise propriamente dita, envolvendo a preparação da amostra por dissolução, extração e assim por diante, seguida da aquisição de dados. Por fim, o melhor resultado é selecionado, e a precisão e a exatidão são definidas (avaliação). Com base nos resultados, a validade do modelo é estabelecida, se necessário, revisada, 
e as operaçōes repetidas (Ambrus,1978; Kratochvil,1987). Todos esses passos afetam o processo de amostragem e são afetados pelo mesmo, e, portanto, essas coletas devem ter total segurança contra tendencias e contaminações.

A exatidão de uma determinação analítica é, então, fortemente dependente da amostra de campo. Para uma determinação ser exata, a amostra deve obedecer a dois conceitos: o de validade e o de representatividade. Uma amostra é válida quando é selecionada de modo a assegurar que cada unidade do material a ser retirada para amostra tenha a mesma probabilidade de ser analisado (procedimento aleatório). A representatividade, por sua vez, tem relação com o tamanho e a composição do material a ser analisado, ou seja, para que uma amostra seja representativa, deve possuir um tamanho e uma composição tal, de modo a assegurar que, se várias subamostras forem tomadas para análise, as variaçōes entre elas sejam insignificantes (Kratochvil,1985; Kratochvil, 1987, Abakerli, 1991).

O trabalho com amostras compostas, produzidas por homogeneização de duas ou mais porções coletadas em diferentes pontos de um mesmo lote, requer um menor número de análises, além de armazenamento, registro e manuseio mais simplificados. Porém, muitas informações úteis podem ser perdidas nessa conduta. A análise de amostras individuais, coletadas adequadamente, permite a determinação da variabilidade intra e interamostras, além da média da composição. Essa informação ajuda a estabelecer a heterogeneidade da população, identificar amostras anômalas e avaliar diferenças intra e interlaboratórios. Portanto, amostras compostas fornecem informaçōes limitadas e devem 
ser empregadas apenas após uma consideração cuidadosa das desvantagens envolvidas (Kratochvil e Peak, 1989).

Se a porção da amostra selecionada é maior do que a quantidade necessária para a análise, deve-se proceder a uma subamostragem do material. Essa operação pode ser simples, para muitos materiais liquidos ou gasosos, ou complexa, para volumes sólidos. O trabalho necessário para produzir uma subamostra uniforme depende da heterogeneidade do material original. Subamostragem de sólidos pode requerer vários passos de redução de partículas e de misturas (Kratochvil, 1985).

O processo para uma amostragem adequada para a análise de residuos de praguicidas representa um problema complexo, em virtude, principalmente, da possibilidade de as concentrações serem baixas e não uniformemente distribuidas. Essa é a razão pela qual não se trabalha com médias, mas sim com medianas e o nonagésimo percentil (Lara,1988).

A distribuição de residuos de praguicidas em um campo tratado é influenciada por vários fatores, como, por exemplo: o tipo de aplicação e de formulação, o número de tratamentos, a dosagem (litro/hectare), o tamanho e a posição dos bicos de pulverização, o modo do cultivo, a variedade e o tipo de cultura, a degradação química, as caracteristicas do solo e as condições climáticas durante a aplicação (Abakerli, 1991).

Em um extenso trabalho de campo e analitico sobre a influência da amostragem na análise de residuos, Ambrus (1978) obteve algumas informações de grande valor prático. Por exemplo, a verificação de que folhas velhas e em crescimento e brotos apresentam capacidades diferentes de absorção do produto, sendo as folhas em crescimento as de maior poder de absorção. 
Em virtude de esses e outros fatores estarem envolvidos na variabilidade dos resultados analíticos, costuma-se, para efeito prático, utilizar o procedimento de composição de amostra. Consiste na obtenção de uma amostra global, de uma maneira aleatória e estratificada. Em seguida, misturam-se as unidades amostradas e tomam-se duas quartas em posições opostas, formando-se, então, a amostra composta. Com essa amostra, pode-se proceder a tratamentos ou práticas agricolas normais, bem como efetuar reduções subseqüentes de tamanho, de modo a tornar a amostra conveniente para o transporte até o laboratório. Nessas condições, ficou comprovado que a média obtida na análise de 10 amostras individuais apresentou um coeficiente de variação de $60 \%$, ao passo que 10 análises da amostra composta apresentaram um coeficiente de variação de $20 \%$ (Abakerli, 1991). 
3-OBJETIVOS 


\subsection{GERAIS}

- Contribuir para o conhecimento da situação em que se encontra o Estado de Pernambuco no que se refere ao uso de praguicidas na agricultura e seu impacto para a saúde e o meio ambiente;

- contribuir para dotar o Estado de Pernambuco de estrutura laboratorial para a análise de residuos de praguicidas, com o objetivo de apoiar programas de vigilância sanitária, controle ambiental e qualidade da produção agricola.

\subsection{ESPECÍFICOS}

- Desenvolver, implementar e validar método multi-residuo para a análise de inseticidas organoclorados e organofosforados, e métodos especificos para a análise de metamidofós e ETU em amostras de tomate;

- analisar residuos de praguicidas na produção de tomate industrial e de mesa do Estado de Pernambuco;

- caracterizar os trabalhadores rurais envolvidos na cultura do tomate segundo aspectos sócio-ambientais e de morbidade. 


\section{4 - MATERIAL E MÉTODOS}




\subsection{DEFINIÇÃO DA ESTRATÉGIA ADOTADA PARA EFEITO DE AMOSTRAGEM}

As duas regiōes selecionadas para estudo, perimetro irrigado do Vale do São Francisco/Projeto Senador Nilo Coelho e Municipio de Camocim de São Félix, apresentam caracteristicas distintas, o que exigiu a adoção de condutas especificas de amostragem, que se adaptassem aos processos de produção existentes. Na medida do possivel, as considerações sobre amostragem foram respeitadas, houve uma grande preocupação de se evitarem tendências, obtendo-se, ao mesmo tempo, amostras com critérios de validade e representatividade.

\subsubsection{PROJETO SENADOR NILO COELHO - TOMATE INDUSTRIAL}

A região com plantio de tomate para processamento ou industrial escolhida para estudo compreende todo o Projeto Senador Nilo Coelho, é composta, essencialmente, por pequenos agricultores, com um bom nivel de organização.

A estrutura existente na produção de tomate industrial pode ser caracterizada por um tipo de sistema fechado (Durval, G., 1993). Os lotes, bem delimitados e cadastrados, são cultivados pelos proprietários e estão dentro de um distrito de irrigação, com registro de propriedade. Há um planejamento de produção, com calendário de plantio, o qual é rigorosamente obedecido.

A área, com cerca de 15.000 hectares, é dividida em 11 núcleos, subdivididos em lotes (Anexo 1). Cerca de 4.000 ha são, normalmente, 
destinados à plantação de tomate.

A época de plantação de tomate nos 11 núcleos é previamente escalonada em função da capacidade das indústrias de processamento, sendo a safra anual a conduta adotada, com o objetivo de diminuir as pragas.

No periodo da realização deste trabalho, o primeiro grupo, compreendendo os núcleos $6,7,8$ e 9 , iniciou o plantio no final de fevereiro/96, considerado período de chuva na região, quando as doenças do tomateiro estão mais presentes. O segundo grupo, núcleos $1,2,3,4$ e 5. plantou em época com condição climatológica intermediária (março/96) e o último grupo, núcleos 10 e 11, em período de seca, caracterizado por uma maior possibilidade de ocorrência de pragas (abril/96). Após 30 dias de sementeira, as mudas de tomate são transplantadas, e leva mais 90 dias o completo amadurecimento do fruto. Portanto, a colheita teve início em junho/julho, com o primeiro grupo e estendeu-se indo até agosto/setembro, com os demais.

Antecipadamente, cada produtor negocia a sua futura safra diretamente com as indústrias, independentemente do núcleo a que pertence. Cabe à indústria "contratada" fornecer aos produtores as sementes e os praguicidas que deverão ser utilizados em suas culturas. Os praguicidas entregues, como forma de adiantamento, diferem um pouco de empresa para empresa, porém, fica a critério do produtor utilizar ou não apenas os produtos fornecidos. Para a safra de 1996, participaram um total de 772 produtores de tomate na região estudada, os quais negociaram com 3 grandes empresas locais de processamento de tomate, a saber: Cica $(8)$, Etti $($ e Tat $\otimes$. 
A autonomia de comercialização dos lotes que compōem cada núcleo caracteriza uma falta de uniformidade dos lotes pertencentes a um mesmo núcleo. Por essa razão, a divisão da área em 11 núcleos não foi considerada para a etapa de amostragem, e, sim, cada lote com plantio de tomate, individualmente.

Tomando-se por base o exposto, duas variáveis foram consideradas no processo de amostragem: 1 - condição climatológica na época do plantio e 2 - empresa fornecedora dos praguicidas.

Assim, todos os lotes do Projeto Senador Nilo Coelho foram divididos em 3 grandes grupos, de acordo com o período de plantio. Cada grupo foi, então, subdividido em 3 subgrupos conforme a empresa contratada. Através de sorteio, segundo o qual todos os lotes com plantação de tomate tiveram as mesmas chances de participação, foram selecionados 3 lotes de cada um dos 3 subgrupos, perfazendo um total de 27 amostras (Tabela 11). Assim, a variável "plantio em época de chuva, intermediária e de seca" foi relacionada com a variável "praguicidas fornecidos por cada empresa, Cica (8, Etti (8) e Tat@". O sorteio dos lotes foi realizado com a participação de técnicos do perimetro, na sede da coordenação do Projeto Senador Nilo Coelho, localizada em Petrolina, com o auxilio do cadastro existente dos lotes/produtores e época de plantio. 
Tabela 11 - Lotes do Projeto Senador Nilo Coelho com plantação de tomate industrial sorteados para estudo, segundo época de plantio e empresa contratada.

\begin{tabular}{ccc}
\hline $\begin{array}{c}\text { época de } \\
\text { plantio }\end{array}$ & $\begin{array}{c}\text { empresa } \\
\text { contratada }\end{array}$ & $\begin{array}{c}\text { número dos lotes sorteados com } \\
\text { respectivos nucloos }\end{array}$ \\
\hline \hline CICA & $N_{7}-1086 / N_{8}-1281 / N_{8}-1296$ \\
FEVEREIRO & ETTI & $N_{6}-682 / N_{7}-1047 / N_{8}-1325$ \\
TARÇO & CICA & $N_{7}-1036 / N_{7}-1081 / N_{9}-1137$ \\
& ETTI & $N_{4}-031 / N_{4}-049 / N_{4}-076$ \\
TAT & $N_{1}-484 / N_{1}-510 / N_{2}-569$ \\
ABRIL & CICA & $N_{10}-1446 / N_{10}-1452 / N_{11}-841$ \\
& ETTI & $N_{10}-1435 / N_{11}-853 / N_{11}-827$ \\
& TAT & $N_{11}-887 / N_{11}-890 / N_{11}-909$ \\
\hline \hline
\end{tabular}

Devido à distância de $700 \mathrm{~km}$ entre o laboratório em Recife e o perímetro irrigado e à existência de apenas um vôo diário, as amostras para análise eram coletadas pela manhã, o mais cedo possivel, acondicionadas e enviadas, por via aérea, no mesmo dia para o laboratório. As amostras eram liberadas pela companhia aérea à noite e transportadas para o laboratório imediatamente para inicio da análise um dia após a coleta em campo. 


\subsubsection{MUNICÍPIO dE CAMOCIM dE SÃo FÉLIX - TOMATE dE MESA}

A seleção de uma região com plantio de tomate de mesa, representativa da produção do Estado, foi realizada com base em relatório fornecido pela Companhia de Abastecimento e de Armazéns Gerais do Estado de Pernambuco-CEAGEPE, onde constam a quantidade de tomate e os municípios do Estado fornecedores do fruto no periodo de 1991 a 1996. Dentre as regiōes de maior fornecimento de tomate de mesa, destacaram-se os município vizinhos, Camocim de São Félix e São Joaquim do Monte (Tabela 12), provavelmente em virtude da altitude e das condiçōes climatológicas características.

Em Camocim de São Félix, a plantação de tomate ocorre de forma desordenada, sem registro oficial da produção e dos produtores existentes, sem assistência técnica adequada ou mesmo coordenação por qualquer tipo de entidade.

O proprietário não é quem trabalha na terra, e o arrendatário, por sua vez, contrata colonos. O nivel técnico dos produtores é primário e a compra de praguicidas é realizada, quase sempre, através de vendedores ocasionais, sem endereço fixo, e, evidentemente, o receituário agronômico é inexistente nessas transações.

A estrutura agrária de produção constitui uma espécie de sistema aberto (Durval, G., 1993), e, na definição do procedimento de amostragem, foi necessário considerar a possibilidade de mudanças na estratégia inicial, com garantia de não introduzir tendências. 
Tabela 12- Comercialização de tomate pela CEAGEPE, segundo quantidade fornecida por municipios pernambucanos, em toneladas, durante 6 anos.

\begin{tabular}{lcccccccc}
\hline \multicolumn{1}{c}{ múnicípio } & 1991 & 1992 & 1993 & 1994 & 1995 & 1996 & TOTAL \\
\hline \hline Arcoverde & 3.514 & 1.285 & 158 & 20 & 49 & 16 & 5.042 \\
Bezerros & 1.266 & 659 & 700 & 265 & 514 & 499 & 3.903 \\
Bonito & 204 & 218 & 343 & 292 & 162 & 83 & 1.302 \\
Cabrobó & 97 & 306 & 214 & 91 & 64 & 28 & 800 \\
Camocim de São & 3.689 & 4.936 & 5.306 & 3.332 & 4.812 & 5.499 & 27.574 \\
Félix & & & & & & & \\
Floresta & 198 & 278 & 1.338 & 1.012 & 434 & 342 & 3.602 \\
Ibimirim & 296 & 510 & 918 & 409 & 412 & 578 & 3.123 \\
Joăo Alfredo & 390 & 54 & 182 & 76 & 118 & 83 & 903 \\
Macaparana & 449 & 442 & 358 & 105 & 209 & 211 & 1.774 \\
Orocó & 249 & 313 & 94 & 45 & - & 69 & 770 \\
Pesqueira & 932 & 405 & 376 & 469 & 218 & 154 & 2.554 \\
Petrolina & 994 & 969 & 2.435 & 1.521 & 988 & 923 & 7.830 \\
Sairé & 520 & 491 & 1.034 & 673 & 921 & 1.011 & 4.650 \\
São Joaquim do & 3.895 & 4.957 & 4.858 & 3.212 & 6.090 & 5.256 & 28.268 \\
Monte & & & & & & & \\
Vitória de Santo & 245 & 150 & 28 & 51 & 113 & 72 & 659 \\
Antăo & & & & & & & \\
\hline Dados for & & & & & & & \\
\hline
\end{tabular}

Dados fornecidos pela Diretoria de Abastecimento da Companhia de Abastecimento e de Armazéns Gerais do Estado de Pernambuco (CEAGEPE).

A identificação e a posterior definição da área a ser estudada foram etapas de certa dificuldade. Foram organizadas visitas prévias ao município, a partir de julho de 1996, com o objetivo de levantar dados da região de cultivo de tomate, através de conversas com habitantes da região, técnicos da Prefeitura, agentes comunitários e com o único técnico de extensão rural da EMATER-PE existente na ocasiăo. 
Os proprietários das terras disponíveis para a agricultura arrendam pequenos lotes, em média de 1,5 ha, a diferentes produtores, para uso em culturas perenes. Em 1996, a área destinada ao cultivo de tomate foi de aproximadamente 150 hectares, envolvendo cerca de 8 a 10 trabalhadores/hectare.

Normalmente, a plantação de tomate tem inicio no mês de agosto e prossegue até o mês de dezembro, e a colheita ocorre entre novembro e maio, com pico de produção em fevereiro. Porém, por não se seguir um calendário muito rígido, muitas alterações são observadas, dependendo do inicio do período de chuva em cada ano, da disponibilidade da terra, do preço do mercado ou da decisão do próprio agricultor. Em 1996, por exemplo, alguns produtores iniciaram a plantação em agosto e garantiram tomate disponivel para comercialização no mês de novembro, quando as primeiras amostras para este trabalho começaram a ser coletadas.

Houve uma tentativa, junto com técnicos da EMATER-PE, da FUNDACENTRO-PE, da Delegacia Regional do Trabalho -DRT e da Secretaria Estadual de Agricultura, de definir, antecipadamente, a produção de tomate para a safra de 1996/97, a partir da identificação do tamanho das propriedades, da quantidade de hectares reservados para o plantio do tomate e dos principais produtores.

Foi, então, estabelecido o estudo de residuos nas propriedades que haviam, inicialmente, destinado cinco ou mais hectares para o plantio de tomate, resultando no total de 6 propriedades, fazendas ou sitios (Tabela 13). Assim, na primeira tentativa, a projeção da amostragem foi feita considerando-se as 6 propriedades identificadas, de onde seriam 
coletadas amostras representativas de cada produtor independentemente, obtendo-se, no total, cerca de 30 amostras compostas.

Tabela 13 - Propriedades de Camocim de São Félix inicialmente selecionadas para estudo.

\begin{tabular}{|c|c|c|c|c|c|}
\hline ordem & localldade & proprietário & $\begin{array}{l}\text { Grea total } \\
\text { (hectare) }\end{array}$ & $\begin{array}{l}\text { drea } \\
\text { destinada } \\
\text { ao tomate }\end{array}$ & $\begin{array}{l}\text { ne provável de } \\
\text { produtores }\end{array}$ \\
\hline 1 & $\begin{array}{c}\text { Sítio } \\
\text { Palmeiras }\end{array}$ & M. G. O. & $43 \mathrm{ha}$ & $7 \mathrm{ha}$ & 3 \\
\hline 2 & $\begin{array}{l}\text { Faz. Boa } \\
\text { Esperança }\end{array}$ & G. C. A. & 184 ha & 6 ha & 2 \\
\hline 3 & Sitio Guará & L. M. S. & $80 \mathrm{ha}$ & 5 ha & 1 \\
\hline 4 & $\begin{array}{l}\text { Sitio Mondé } \\
\text { dos Cabrais }\end{array}$ & M. G. O. & $98 \mathrm{ha}$ & 7 ha & 13 \\
\hline 5 & $\begin{array}{c}\text { Sítio } \\
\text { Palmeiras }\end{array}$ & S. X. S. & $66 \mathrm{ha}$ & 5 ha & 1 \\
\hline 6 & $\begin{array}{c}\text { Fazenda } 3 \\
\text { Marias }\end{array}$ & L. $G$. & 205 ha & 20 ha & A definir \\
\hline
\end{tabular}

Porém, a área total de plantio estimada inicialmente foi alterada ao longo do período de cultivo, devido às flutuações do preço do tomate no mercado, o que desestimulou alguns produtores, ou mesmo pela escassez de água para irrigação, problema constante na região. Alguns proprietários deixaram de plantar, como foi o caso do Sitio Guará $\left(n^{\circ} 3\right)$ e Palmeiras $\left(n^{\circ}\right.$ 5), ou iniciaram o plantio tardiamente, e ainda outros, que produziam em grande escala, diminuíram a produçăo, como a Fazenda 3 Marias ( $\left.n^{\circ} 6\right)$, ocorrendo, também, a situação inversa. Esse fato exigiu um constante acompanhamento do cultivo nas áreas pré-selecionadas, decorrendo pequenas alterações ao longo do trabalho, de forma a não prejudicar um plano de amostragem confiável.

Após uma reavaliaçăo do plano inicialmente proposto, duas 
propriedades foram excluidas do trabalho (Guará e Palmeiras), passandose, então, a trabalhar com 11 propriedades de tamanhos diversos. O critério de seleção adotado foi a escolha das mais extensas, com possibilidade de acesso através de veículo automotor e autorização dos produtores para a entrada dos técnicos na plantação para a coleta de tomates. Foram, então, coletadas amostras de tomate em 32 plantações de produtores distintos, em áreas pertencentes às 11 propriedades.

Os novos pontos de coleta estão identificados nas Tabelas 14 e 15 , e o Anexo II mostra o mapa do municipio de Camocim de São Félix, obtido por imagem de satélite digitalizada, com a distribuição espacial aproximada dos pontos amostrados.

No total, foram realizadas 8 viagens, com o objetivo de coleta em campo, compreendidas entre os meses de dezembro de 1996 e abril de 1997. As amostras coletadas, devidamente embaladas, eram imediatamente enviadas para o laboratório.

As 11 propriedades, juntas, destinaram cerca de 65 hectares para o plantio de tomate na safra 96/97, conforme mostra a Tabela 15. Portanto, as 32 amostras de tomate coletadas, provenientes de uma área total de 42,6 hectares (Tabelas 14 e 15), representaram $65 \%$ do plantio de tomate nas propriedades selecionadas. Estima-se que a área de plantio, em todo - municipio, tenha sido de cerca de 150 hectares, o que significa uma amostragem em $28,4 \%$ de toda a plantação de tomate. 
Tabela 14 - Identificação dos pontos de coleta de tomate em Camocim de São Félix para a análise de resíduos de praguicidas, com as respectivas áreas cultivadas, data de coleta da amostra para análise e datas de plantio e colheita.

\begin{tabular}{|c|c|c|c|c|c|c|}
\hline ordem & $\begin{array}{l}\text { propriedade } \\
\text { fazenda/sitio }\end{array}$ & produtor & $\begin{array}{l}\text { drea } \\
\text { cultiva- } \\
\text { da }\end{array}$ & $\begin{array}{l}\text { data } \\
\text { coleta } \\
\end{array}$ & $\begin{array}{l}\text { data } \\
\text { plantio }\end{array}$ & $\begin{array}{l}\text { data } \\
\text { collhelta }\end{array}$ \\
\hline 1 & Boa Esperança & S. L. N. & $1,5 \mathrm{ha}$ & $03 / 12 / 96$ & 10/09/96 & $18 / 11 / 96$ \\
\hline 2 & Três Marias & S. J.S. & 3,0 ha & $03 / 12 / 96$ & $20 / 08 / 96$ & $06 / 11 / 96$ \\
\hline 3 & Três Marias & R. S. S. & 0,5 ha & $03 / 12 / 96$ & $22 / 08 / 96$ & $15 / 11 / 96$ \\
\hline 4 & Boa Esperança & G. S. S. & $2,0 \mathrm{ha}$ & $03 / 12 / 96$ & $10 / 09 / 96$ & $28 / 11 / 96$ \\
\hline 5 & Mondé dos Cabrais & N. B. S. & $1,0 \mathrm{ha}$ & $08 / 01 / 97$ & $20 / 08 / 96$ & \\
\hline 6 & Mondé dos Cabrais & M. G. & 2,0 ha & $08 / 01 / 97$ & $20 / 08 / 96$ & \\
\hline 7 & Alagado & J. A. & 2,5 ha & $08 / 01 / 97$ & $05 / 11 / 96$ & $20 / 01 / 97$ \\
\hline 8 & Cruz de Rajada & J. A. S. & 2,0 ha & $05 / 02 / 97$ & $01 / 10 / 96$ & $06 / 01 / 97$ \\
\hline 9 & Lagoa do Ramalho & S. F. C. & 1,0 ha & $05 / 02 / 97$ & $15 / 10 / 97$ & $15 / 01 / 97$ \\
\hline 10 & Boa Vista & F. M. S. & $1,5 \mathrm{ha}$ & $27 / 02 / 97$ & $01 / 10 / 96$ & $02 / 03 / 97$ \\
\hline 11 & Boa Vista & J.S. S. & 1,0 ha & $27 / 02 / 97$ & $08 / 10 / 96$ & $27 / 02 / 97$ \\
\hline 12 & Palmeira & F. V. S. & $1,5 \mathrm{ha}$ & $27 / 02 / 97$ & $14 / 10 / 96$ & $27 / 02 / 97$ \\
\hline 13 & Lagoa do Ramalho & A. G. & 2,0 ha & $27 / 02 / 97$ & $04 / 11 / 96$ & $20 / 02 / 97$ \\
\hline 14 & Lagoa do Ramalho & M. F. C. & 2,0 ha & $27 / 02 / 97$ & $25 / 11 / 96$ & $25 / 02 / 97$ \\
\hline 15 & Mocós & R. 0 . & $0,5 \mathrm{ha}$ & $12 / 03 / 97$ & $27 / 12 / 97$ & $06 / 03 / 97$ \\
\hline 16 & Mocós & J. A. M. & $1,0 \mathrm{ha}$ & $12 / 03 / 97$ & $18 / 12 / 96$ & $20 / 02 / 97$ \\
\hline 17 & Mocós & G. & $0,5 \mathrm{ha}$ & $12 / 03 / 97$ & $23 / 12 / 97$ & $04 / 03 / 97$ \\
\hline 18 & Mocós & s. v. & $1,0 \mathrm{ha}$ & $12 / 03 / 97$ & $15 / 12 / 96$ & $12 / 03 / 97$ \\
\hline 19 & Nossa Sra. Carmo & F. M. & $2,0 \mathrm{ha}$ & $12 / 03 / 97$ & $03 / 12 / 96$ & $12 / 03 / 97$ \\
\hline 20 & Lagoa do Ramalho & J. E. M. & $2,0 \mathrm{ha}$ & $19 / 03 / 97$ & $06 / 12 / 96$ & $18 / 03 / 97$ \\
\hline 21 & Cruz de Rajada & F. V. S. & $1,0 \mathrm{ha}$ & $19 / 03 / 97$ & $02 / 12 / 96$ & $15 / 03 / 97$ \\
\hline 22 & Cruz de Rajada & L. N. & $1,0 \mathrm{ha}$ & $19 / 03 / 97$ & $16 / 12 / 96$ & $29 / 03 / 97$ \\
\hline 23 & Lagoa do Ramalho & $F$ & $1,0 \mathrm{ha}$ & $19 / 03 / 97$ & $22 / 12 / 96$ & $19 / 03 / 97$ \\
\hline 24 & Lagoa do Ramalho & & $1,0 \mathrm{ha}$ & $19 / 03 / 97$ & $22 / 11 / 96$ & $30 / 03 / 97$ \\
\hline 25 & Palmeiras & J. G. S. & $2,0 \mathrm{ha}$ & $26 / 03 / 97$ & $25 / 12 / 96$ & $01 / 03 / 97$ \\
\hline 26 & Palmeiras & E. S. S & 2,0 ha & $26 / 03 / 97$ & $14 / 12 / 96$ & $26 / 03 / 97$ \\
\hline 27 & Pacas II & M. B. S. & $0,5 \mathrm{ha}$ & $08 / 04 / 97$ & $03 / 02 / 96$ & $01 / 04 / 97$ \\
\hline 28 & Pacas II & J. J. S. & 0,4 ha & $08 / 04 / 97$ & $16 / 01 / 97$ & $20 / 04 / 97$ \\
\hline 29 & Pacas II & M. J. L. & $1,5 \mathrm{ha}$ & $08 / 04 / 97$ & $04 / 02 / 97$ & $02 / 04 / 97$ \\
\hline 30 & Pacas II & S. M. L. & 0,5 ha & $08 / 04 / 97$ & $18 / 01 / 97$ & $18 / 03 / 97$ \\
\hline 31 & Pacas II & J. M. S. & $0,5 \mathrm{ha}$ & $08 / 04 / 97$ & $03 / 02 / 97$ & $01 / 04 / 97$ \\
\hline 32 & Mocós & M. J. A. & $0,7 \mathrm{ha}$ & $08 / 04 / 97$ & $03 / 02 / 97$ & $08 / 04 / 97$ \\
\hline
\end{tabular}


Tabela 15 - Distribuição das amostras de tomate coletadas em Camocim de são félix para análise de praguicidas, em relação às propriedades e áreas cultivadas.

\begin{tabular}{|c|c|c|c|c|}
\hline ordem & propriedado & $\begin{array}{l}\text { area amostrada } \\
\text { complantio de } \\
\text { tomate }\end{array}$ & $\begin{array}{l}\text { área total com } \\
\text { plantio de tomate }\end{array}$ & $\begin{array}{c}\text { no de amostras } \\
\text { coletadas para } \\
\text { análise }\end{array}$ \\
\hline 1 & Alagado & 2,5 ha & $2,5 \mathrm{ha}$ & 1 \\
\hline 2 & Boa Esperança & 3,5 ha & $6,0 \mathrm{ha}$ & 2 \\
\hline 3 & Boa Vista & 2,5 ha & 2,5 ha & 2 \\
\hline 4 & Cruz da Rajada & 4,0 ha & 4,0 ha & 3 \\
\hline 5 & Lagoa do Ramalho & 9,0 ha & 9,0 ha & 6 \\
\hline 6 & Mocós & 3,7 ha & 3,7 ha & 5 \\
\hline 7 & Mondé dos Cabrais & 3,0 ha & 7,0 ha & 2 \\
\hline 8 & $\begin{array}{c}\text { Nossa Sra. do } \\
\text { Carmo }\end{array}$ & $2,0 \mathrm{ha}$ & 2,0 ha & 1 \\
\hline 9 & Pacas & 3,4 ha & 3,4 ha & 5 \\
\hline 10 & Palmeira & 5,5 ha & 5,0 ha & 3 \\
\hline 11 & Três Marias & 3,5 ha & 20 ha & 2 \\
\hline$\overline{\text { TOTAL }}$ & & 42,6 ha & $65,1 \mathrm{ha}$ & 32 \\
\hline
\end{tabular}

\subsection{PROCEDIMENTO PARA A COLETA DAS AMOSTRAS NO CAMPO SELECIONADO}

No procedimento da coleta de tomate no campo selecionado para o desenvolvimento desse trabalho foram utilizadas amostras compostas por frutos coletados em 15 pontos diferentes do mesmo lote ou plantação. Ao ser selecionada a área de coleta, seguindo-se as linhas de um "Z" imaginário cobrindo-se toda a plantação e eliminando-se a bordadura, 3 tomates foram coletados em 15 pontos diferentes, conforme o esquema da Figura 5 (Kratochvil e Peak, 1989). Ao se escolherem os 3 tomates de cada ponto, teve-se o cuidado de selecionar frutos com possíveis 
diferenças na exposição aos praguicidas (Ambrus, 1978). Cada amostra composta, representada por 45 frutos de um mesmo lote, pesava cerca de $6 \mathrm{~kg}$ de tomate industrial e cerca de $10 \mathrm{~kg}$ de tomate de mesa.

Papel aluminio foi utilizado para envolver as amostras, evitando-se contato com qualquer outro material de embalagem. Após o acondicionamento, em caixas de isopor com gelo reciclável, o envio para o laboratório era realizado imediatamente.

Uma vez no laboratório, as amostras passavam por um quarteamento, e, por eliminação dos quartis opostos, alcançava-se a quantidade a ser triturada e homogeneizada (Batista, 1986; ). A extração era realizada em seguida, no menor espaço de tempo possivel, ficando o material remanescente armazenado em congelador, para fins de repetições.

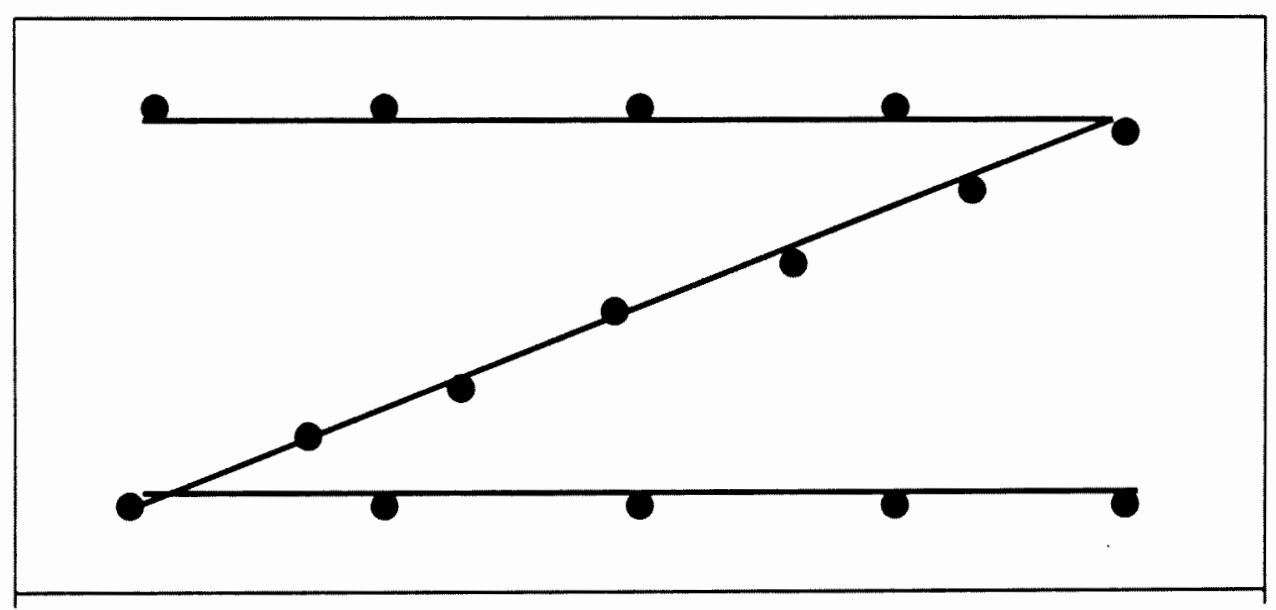

Figura 5 - Esquema utilizado para a coleta de tomate em cada campo selecionado. 


\section{3. - CLASSES DE PRAGUICIDAS SELECIONADAS PARA INVESTIGAÇÃO ANALITICA}

Considerando a disponibilidade laboratorial e os recursos limitados para a execução do trabalho analitico, foi necessário assumir que apenas alguns principios ativos poderiam ser investigados, o que exigia uma seleção prévia. Como havia interesse na comparação dos resultados obtidos entre os processos de produção para a cultura do tomate praticados nas duas regiōes de estudo, os princípios ativos selecionados para a análise deveriam ser os mesmos, seguindo-se um critério único de seleção.

O primeiro passo nesse sentido foi avaliar os levantamentos sobre o uso de praguicidas no tomateiro existentes para as duas regiōes de interesse, obtidos por órgãos comuns: EMATER-PE, Secretarias de Agricultura do Estado e Prefeituras.

Em média, foram citados 12 principios ativos para o município de Petrolina e 25 em Camocim de São Félix. Analisando-se esses dados frente ao risco e à gravidade do dano ao ambiente e à saúde dos expostos e, sobretudo, à estrutura analitica disponivel na ocasião, foram selecionados para estudo alguns inseticidas organofosforados, organoclorados e fungicidas da classe dos etilenobisditioarbamatos (EBDCs).

Segundo a nossa legislação, o uso de inseticidas organoclorados é restrito, não sendo autorizado em culturas de tomate. A sua inclusão neste trabalho deve-se ao interesse de se verificarem algumas denúncias e 
suspeitas existentes no que se refere ao uso indevido, e não ao conhecimento oficial de seu uso na cultura de tomate.

\section{4. - AVALIAÇÃO DOS tIPOS DE PRAGUICIDAS UTILIZADOS NO ESTADO DE PERNAMBUCO}

Para esse objetivo foram utilizados dados secundários obtidos de diversas fontes do Estado: Secretaria Estadual de Agricultura (1997), EMATER (1990, 1991 e 1997) e Secretaria de Agricultura do Municipio de Petrolina (1995). Foram utilizados, também, dados primários obtidos através de questionários respondidos por produtores das áreas onde as amostras de tomate para análise de residuos foram coletadas.

Os dados secundários foram analisados com o objetivo de: (1) estabelecer a distribuição do uso de praguicidas em todo o Estado segundo a divisão por mesorregiōes; (2) avaliar se essa distribuição é coerente com as culturas tradicionalmente praticadas em cada uma dessas regiões; (3) verificar quais as classes de praguicidas mais utilizadas; (4) identificar o uso de produtos sem registro desconhecido, cancelado ou não permitido, segundo a legislação vigente.

Foi utilizado, como referência, o programa AGROFIT/97, elaborado e cedido graciosamente pela Coordenação de Fiscalização de Agrotóxicos do Ministério da Agricultura, e as monografias das Portarias do Ministério da Saúde publicadas pelo ILSI-Brasil (1995). 


\section{5. - LEVANTAMENTO DE DADOS SÓCIO-AMBIENTAIS E DE MORBIDADE REFERIDA EM TRABALHADORES ENVOLVIDOS NA CULTURA DO TOMATE}

\section{- Projeto Senador Nilo Coelho}

Foi elaborado um questionário simples (Anexo III) para ser respondido pelos agricultores responsáveis pelos lotes sorteados. 0 questionário foi um instrumento utilizado para a obtenção de informações sobre o produto aplicado, dados gerais sobre saúde e segurança ocupacional.

Durante a realização do trabalho de campo, não havia, em Petrolina, uma estrutura local capaz de oferecer cobertura para a área de saúde, inquérito epidemiológico ou social. Por se tratar de um primeiro trabalho do gênero na região e considerando a distância, os custos envolvidos e a falta de pessoal treinado, não foi possivel a ampliação e o aprofundamento do inquérito, sobretudo no que se refere à aplicação de um questionário mais complexo. Por outro lado, trata-se de uma região com vários dados registrados e um eficiente controle do processo produtivo.

Após visitas ao local, o levantamento de informações existentes e da estrutura disponivel, além de discussão com os técnicos dispostos a colaborar, foi definida uma estratégia de estudo. Técnicos da área agronômica do Distrito de Irrigação do Projeto Senador Nilo Coelho ficaram responsáveis pela coleta em campo e aplicação dos questionários, enquanto que o acondicionamento e o envio das amostras para o laboratório ficaram sob a responsabilidade de técnicos da EMBRAPA/CPATSA. 
- Municipio de Camocim de São Félix

Nessa parte do trabalho, houve a possibilidade da participação de diferentes órgãos, compatibilizando vários interesses. Assim, foi possivel, através de um questionário semi-estruturado (Anexo IV) dirigido aos trabalhadores rurais, fazer um inquérito epidemiológico e caracterizar as condições de trabalho e ambientais, e levantar a morbidade referida, relacionadas no processo produtivo do tomate. Este inquérito contou com a colaboração, para elaboração e aplicação, de técnicos representando diversos órgãos que também tinham outros objetivos no estudo dessa produção agrícola: pesquisadores do Núcleo de Estudos em Saúde Coletiva -NESC/CPqAM/FIOCRUZ, técnicos da área da saúde ligados ao Programa de Vigilância da Saúde do Trabalhador da Secretaria da Saúde do Estado e agentes da saúde da Prefeitura de Camocim de São Félix.

Participaram dessa etapa 8 agentes comunitários de saúde do município, supervisionados pela equipe de pesquisa, composta por um médico, um engenheiro agrônomo, um técnico de segurança e dois técnicos agricolas.

Dadas as condiçōes de imprevisibilidade na atividade rural, a grande dispersão e as dificuldades de reunir os trabalhadores dentro ou fora da atividade produtiva, optou-se por saber no momento da coleta de tomate para análise, quantos trabalhadores estavam naquela propriedade e estabelecer como alvo para a aplicação do inquérito epidemiológico $50 \%$ do efetivo do dia. Foi seguida a seguinte orientação: com autorização do produtor e acompanhados pelo técnico de extensão rural da EMATER-PE, os técnicos entravam no campo e, na medida em que iam encontrando os 
trabalhadores, independentemente de idade ou sexo, convidavam-nos a responder o questionário, até completar o número definido para aquela propriedade, de acordo com a estimativa de área de cultivo do tomate.

Segundo informação da EMATER-PE, são utilizados, no plantio de tomate, cerca de 8 trabalhadores por hectare. Então, para as propriedades selecionadas, que representavam um total de 65,1 hectares, cerca de 520 trabalhadores deveriam estar envolvidos na produção do tomate para aquela safra e, aproximadamente, 340 nos 42,6 hectares amostrados.

Foi estabelecido como meta atingir, no mínimo, $25 \%$ da população de trabalhadores rurais, ou seja, $1 / 4$ da população, o que equivaleria a 130 trabalhadores das 11 propriedades. Foram realizadas 159 entrevistas, o que significou cerca de $30,6 \%$ da população trabalhadora total prevista. Considerando apenas a área de coleta de tomate para análise, $46,6 \%$ da população participaram do inquérito epidemiológico.

Para o mapeamento da região, o levantamento das áreas de produção, a elaboração e a aplicação do inquérito epidemiológico, a coleta de tomate e o envio para o laboratório, foi necessária a mobilização de diversos setores e o envolvimento de profissionais ligados a órgãos municipais, estaduais e federais. A EMATER-PE colaborou com um técnico de extensão rural, conhecedor da região e dos produtores, para o mapeamento da área e para facilitar o acesso às propriedades; a FUNDACENTRO, as Secretarias Estaduais da Agricultura e da Saúde cederam transporte durante todo o trabalho e técnicos, que foram encarregados da coleta, do acondicionamento e do envio dos tomates para - laboratório ou da aplicação dos questionários; a elaboração do questionário e o treinamento dos técnicos responsáveis pela sua aplicação 
ficaram a cargo de pesquisadores do NESC/CPQAM/FIOCUZ, participantes, também, das etapas de amostragem e entendimento da região; estudantes de pós-graduação do NESC ficaram responsáveis pelo treinamento de agentes comunitários para o auxilio na aplicação dos questionários, o acompanhamento do trabalho de campo e a organização computacional dos dados levantados; a Prefeitura do municipio forneceu agentes de saúde e veículo para a circulação entre as plantações, e a FACEPE, órgão estadual de fomento à pesquisa, forneceu auxílio para o pagamento de diárias e parte das análises laboratoriais realizadas.

\subsection{MÉTODOS ANALITIICOS}

Foi utilizado um método multi-residuo para a análise de 21 inseticidas organoclorados e 9 inseticidas organofosforados. Porém, foi necessária a aplicação de um método especifico para a análise do inseticida organofosforado metamidofós, em virtude de sua alta polaridade. A inclusão do metamidofós neste estudo foi considerada importante, por ser este um principio ativo presente em formulações de grande uso na cultura do tomate, como o Tamaron (8.

Pela mesma razão, ou seja, pela grande utilização em culturas de tomate, o estudo dos fungicidas da classe dos etilenobisditiocarbamatos

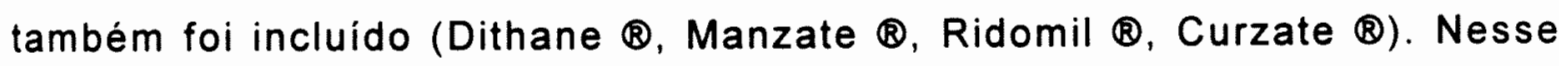
caso, porém, houve necessidade de uma pesquisa mais aprofundada sobre o assunto, bem como de diversos experimentos analíticos prévios, devido, 
sobretudo, à ausência de método oficial, aceito internacionalmente, para o controle de residuos dos EBDCs.

\subsection{1. - CUIDADOS E PROCEDIMENTOS ESPECIAIS DURANTE AS ANÁLISES DE RESÍDUOS DE PRAGUICIDAS}

- Solventes: considerados de alto grau de pureza, "grau pesticida", a fim de evitar interferências na análise; a cada mudança de lote, uma aliquota do solvente era concentrada e analisada;

- sulfato e cloreto de sódio, usados para a adsorção de água e para evitar eventuais emulsões na fase de extração, respectivamente: previamente calcinados a $550-600^{\circ} \mathrm{C}$, por $12 \mathrm{~h}$;

- florisil utilizada na preparação da coluna para a purificação dos extratos: calcinada por $12 \mathrm{~h}$ a $550-600^{\circ} \mathrm{C}$ e deixada em repouso em dessecador, à temperatura ambiente por, no minimo, $2 \mathrm{~h}$, antes do procedimento de desativação;

- desativação da florisil: o teste para a escolha do melhor percentual de desativação da florisil era realizado com o auxílio de um adicionado de inseticidas organoclorados em óleo; a florisil desativada estava pronta para uso por um periodo de até 3 dias;

- água utilizada na padronização do adsorvente (florisil) e na hidratação das amostras: purificada com uma mistura de éter de petróleo: cloreto de metileno, na proporção de 4:1; 
- limpeza de vidraria, espátulas e tampas: lavagem com extran alcalino (Merck (8), 2 a $5 \%, e$, em seguida, com bastante água corrente e água destilada e desmineralizada;

- controle do material utilizado: lã de vidro, evaporador rotativo, vidraria, espátulas e demais materiais eram descontaminados com hexano ou éter de petróleo antes do uso; periodicamente, era realizado um teste de avaliação de uma possivel contaminação;

- balões volumétricos utilizados com padrões ou amostras concentradas: eram colocados no ultrassom, com extran alcalino (Merck (B), por 45 minutos a 1 hora, antes da lavagem indicada para vidraria;

- todos os cromatogramas obtidos nessa fase eram analisados para a verificação da necessidade de nova descontaminação ou da presença de picos que pudessem interferir na quantificação dos praguicidas estudados.

4.6.2 - MÉTODO PROPOSTO PARA ANÁLISE DE INSETICIDAS ORGANOCLORADOS EM AMOSTRAS DE TOMATE

\section{- Soluções - padrão}

As soluções - padrão de aldrin, dieldrin, endrin, HCB, heptacloro, heptacloro epóxido, mirex, p-p'- DDE, o-p'- DDD, p-p'- DDD, o-p'- DDT, pp'- DDT, $\alpha$ - clordano, $\gamma$ - clordano, $\alpha-\mathrm{HCH}, \beta-\mathrm{HCH}, \gamma-\mathrm{HCH}, \delta-\mathrm{HCH}, \alpha$ - endosulfan, $\beta$ - endosulfan e endosulfan na forma de sulfato foram preparadas em iso-octano grau pesticida (Merck (8)). 
As soluções-estoque dos 18 primeiros padrões foram diluidas para a obtenção das soluçōes de trabalho, em diferentes concentrações. As três soluções-padrão de endosulfan, $\alpha, \beta$ e sulfato, foram diluidas até a solução de trabalho, também em diferentes concentrações. Todas as diluições foram preparadas com iso-octano grau pesticida (Merck (8)).

- Extração de inseticidas organoclorados em amostras de tomate e purificação dos extratos obtidos

O método multi-resíduos de referência para a análise dos clorados e fosforados, validado e aplicado neste trabalho, foi publicado por um grupo de pesquisa holandês, envolvido no desenvolvimento e melhoramento de métodos para análise de residuos (Dutch Ministry of Public Health, Welfare and Sport, 1996). Após algumas adaptações citadas em outras metodologias (Mitchell, 1976 e Luke, 1975), foi estabelecida a seguinte marcha analítica:

1. A 15 gramas da amostra de tomate, acompanhados das amostras de "branco" e adicionado, foram adicionados $25 \mathrm{~mL}$ de acetato de etila; após duas etapas de agitação vigorosa e repouso por $2 \mathrm{~min}$, sulfato de sódio anidro foi adicionado, com agitação, até a água ficar aderida ao sulfato; $5 \mathrm{~mL}$ da fase orgânica foram evaporados até a secura, com corrente de nitrogênio;

2. o extrato seco foi ressuspenso com $5 \mathrm{~mL}$ de éter de petróleo e transferido para uma coluna de vidro contendo cerca de $6 \mathrm{~g}$ de florisil, previamente preparada. Mantendo-se o fluxo de $5 \mathrm{~mL} / \mathrm{min}$, os inseticidas organoclorados foram eluidos da coluna de florisil com $60 \mathrm{~mL}$ de duas misturas passadas pela coluna, na seguinte ordem: primeiro, a mistura 
contendo éter de petróleo e cloreto de metileno (4:1), e, em segundo, a mistura contendo éter de petróleo e cloreto de metileno (6:4);

3. os dois extratos obtidos nesta fase foram evaporados, separadamente, em evaporador rotativo até cerca de $5 \mathrm{~mL}$, e até a secura, com o auxílio de um fluxo de nitrogênio; os extratos secos foram, então, ressuspensos com $5 \mathrm{~mL}$ de éter de petróleo, estando prontos para injeção no cromatógrafo a gás.

O fluxograma do método multi-residuos utilizado está ilustrado na Figura 6.

\section{- Análise por cromatografia em fase gasosa}

Foi empregado um cromatógrafo a gás Hewlett Packard, modelo 5890-serie 11, acoplado a detetor de captura de elétrons, com integrador Hewlett Packard, modelo 3396-serie II, e insersor do tipo splitless. A separação foi obtida em coluna cromatográfica capilar Ultra 2, $5 \%$ metilfenil silicone, $25 \mathrm{~m} \times 0,2 \mathrm{~mm}$ de diâmetro interno e $0,33 \mu \mathrm{m}$ de espessura de fase. O hélio foi utilizado como gás de arraste, com fluxo de $1 \mathrm{~mL} / \mathrm{min}$, e o nitrogênio, como gás auxiliar, com fluxo de $50 \mathrm{~mL} / \mathrm{min}$. 


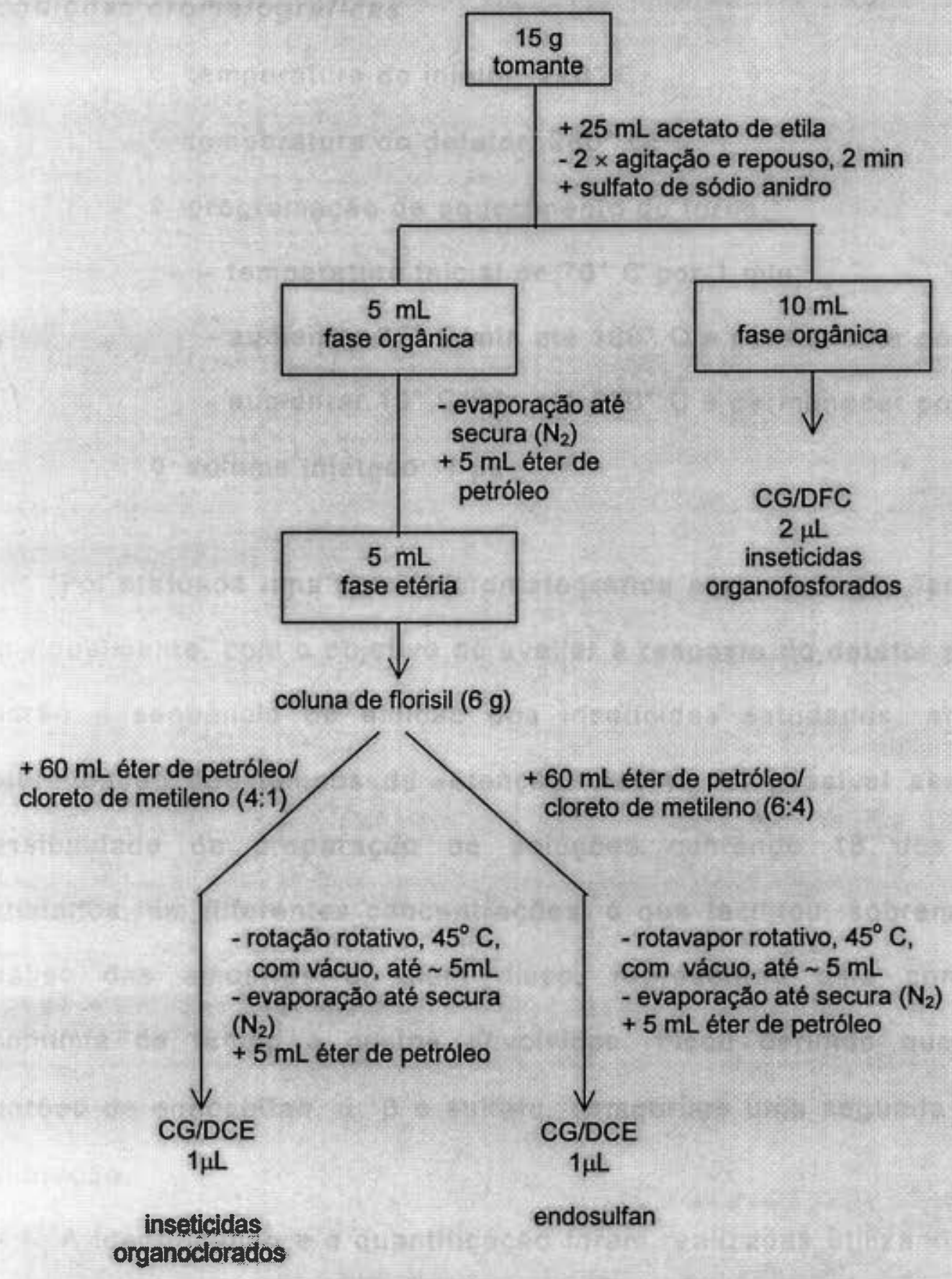

Figura 6 - Fluxograma do procedimento analítico usado na determinação de inseticidas organoclorados e organofosforados em amostras de tomate. 


\section{Condiçōes cromatográficas}

$\diamond$ temperatura do injetor: $220^{\circ} \mathrm{C}$;

$\diamond$ temperatura do detetor: $280^{\circ} \mathrm{C}$;

$\checkmark$ programação de aquecimento do forno:

- temperatura inicial de $70^{\circ} \mathrm{C}$ por $1 \mathrm{~min}$;

- aumentar $25^{\circ} \mathrm{C} / \mathrm{min}$ até $180^{\circ} \mathrm{C}$ e permanecer por $1 \mathrm{~min}$;

- aumentar $10^{\circ} \mathrm{C} / \mathrm{min}$ até $230^{\circ} \mathrm{C}$ e permanecer por $30 \mathrm{~min}$;

$\diamond$ volume injetado: $1 \mu \mathrm{L}$

Foi efetuada uma corrida cromatográfica para cada um dos padrões individualmente, com o objetivo de avaliar a resposta do detetor para cada padrão e seqüência de eluição dos inseticidas estudados, através da determinação dos tempos de retenção. Assim, foi possivel assegurar a possibilidade da preparação de soluções contendo 18 dos padrões estudados, em diferentes concentrações, o que facilitou, sobremaneira, a análise das amostras e, além disso, representou uma considerável economia de tempo e custos envolvidos. Ficou definido que os três padrões de endosulfan, $\alpha, \beta$ e sulfato, comporiam uma segunda curva de calibração.

A identificação e a quantificação foram realizadas utilizando-se uma curva de calibração, cujos cálculos foram obtidos pela área versus a concentração de cada um dos padrões (Tabelas 16 e 17).

Colunas cromatográficas de diferentes polaridades foram selecionadas para a necessidade de eventuais confirmações da presença dos principios ativos estudados. 
Tabela 16 - Concentração das soluções preparadas para a obtenção das curvas de calibração de 18 padrōes de inseticidas organoclorados, por ordem de eluição nas condiçōes cromatográficas estabelecidas.

\begin{tabular}{|c|c|c|c|c|}
\hline padrão & A & $\begin{array}{c}\text { soluc } \\
\text { B }\end{array}$ & $\mathrm{ng} / \mathrm{mL}$ & D \\
\hline$\alpha-\mathrm{HCH}$ & 1,24 & 2,49 & 4,98 & 9,96 \\
\hline HCB & 0,62 & 1,24 & 2,48 & 4,96 \\
\hline$\beta-\mathrm{HCH}$ & 1,26 & 2,53 & 5,06 & 10,12 \\
\hline$\gamma-\mathrm{HCH}$ & 1,26 & 2,53 & 5,06 & 10,12 \\
\hline$\delta-\mathrm{HCH}$ & 1,33 & 2,67 & 5,34 & 10,68 \\
\hline heptacloro & 1,27 & 2,55 & 5,10 & 10,20 \\
\hline aldrin & 1,24 & 2,48 & 4,96 & 9,92 \\
\hline $\begin{array}{l}\text { heptacloro } \\
\text { epóxido }\end{array}$ & 1,24 & 2,48 & 4,96 & 9,92 \\
\hline$\gamma$ - clordano & 1,25 & 2,51 & 5,02 & 10,04 \\
\hline$\alpha$ - clordano & 1,29 & 2,59 & 5,18 & 10,36 \\
\hline pp'- DDE & 1,24 & 2,49 & 4,98 & 9,96 \\
\hline dieldrin & 1,26 & 2,52 & 5,04 & 10,08 \\
\hline op'- DDD & 1,27 & 2,55 & 5,10 & 10,20 \\
\hline endrin & 1,42 & 2,84 & 5,68 & 11,36 \\
\hline pp'- DDD & 3,15 & 6,30 & 12,60 & 25,20 \\
\hline op'- DDT & 3,08 & 6,17 & 12,34 & 24,68 \\
\hline pp'- DDT & 3,12 & 6,25 & 12,50 & 25,00 \\
\hline mirex & 3,12 & 6,37 & 12,70 & 25,40 \\
\hline
\end{tabular}

Tabela 17 - Concentração das soluçōes preparadas para a obtenção das curvas de calibração de 3 padrōes de endosulfan, por ordem de eluição nas condições cromatográficas estabelecidas.

\begin{tabular}{|c|c|c|c|c|}
\hline padráo & $\mathrm{A}$ & $\begin{array}{c}\text { lug ore } \\
B\end{array}$ & $\mathrm{~g}_{\mathrm{C}}$ & D) \\
\hline $\begin{array}{c}\alpha \text { - endosulfan } \\
\beta \text { - endosulfan } \\
\text { endosulfan sulfato }\end{array}$ & $\begin{array}{l}2,48 \\
2,6 \\
5,06\end{array}$ & $\begin{array}{c}4,96 \\
5,2 \\
10,12\end{array}$ & $\begin{array}{c}9,92 \\
10,4 \\
15,18\end{array}$ & $\begin{array}{c}14,88 \\
15,6 \\
25,3\end{array}$ \\
\hline
\end{tabular}




\subsubsection{MÉTODO PROPOSTO PARA A ANÁLISE DE INSETICIDAS ORGANOFOSFORADOS EM AMOSTRAS DE TOMATE}

\section{- Soluções-padrão}

As soluções-padrão de diclorvós, fosdrin, diazinon, fenclorvós, pirimifós metil, paration metil, malation, fenitrotion, paration etil foram preparadas em acetato de etila grau pesticida (Merck (8)).

As soluções-estoque foram diluidas para a obtenção das soluções de trabalho, em diferentes concentrações. Todas as diluições foram preparadas com acetato de etila grau pesticida (MercK (B)).

- Extração de inseticidas organofosforados em amostras de tomate

Foi utilizado o método multi-residuos, esquematizado na Figura 6 , excluindo-se a fase de purificação em coluna de florisil:

1. A 15 gramas da amostra de tomate, acompanhados das amostras de "branco" e adicionado, foram adicionados $25 \mathrm{~mL}$ de acetato de etila. Após duas etapas de agitação vigorosa e repouso por $2 \mathrm{~min}$, sulfato de sódio anidro foi adicionado, com agitação, até a água ficar aderida ao sulfato. A fase orgânica foi transferida para um balão volumétrico de $10 \mathrm{~mL}$, estando pronta para injeção no cromatógrafo a gás.

\section{- Análise por cromatografia em fase gasosa}

Foi empregado um cromatógrafo a gás Hewlett Packard, modelo 5890-serie II, acoplado a detetor fotométrico de chama, com integrador Hewlett Packard, modelo 3396-serie II. A separação foi obtida em coluna cromatográfica de $1,8 \mathrm{~m} \times 1 / 8^{\prime \prime}$, suporte sólido Chromosorb W-HP 80-100 
mesh e fase estacionária composta de $1,5 \%$ oV $17 \%+1,95 \%$ oV 210 . O nitrogênio foi utilizado como gás de arraste, com fluxo de $30 \mathrm{~mL} / \mathrm{min}$.

\section{Condições cromatográficas}

$\checkmark$ temperatura do injetor: $220^{\circ} \mathrm{C}$;

$\checkmark$ temperatura do detetor: $220^{\circ} \mathrm{C}$;

$\checkmark$ programação de aquecimento do forno:

- temperatura inicial de $200^{\circ} \mathrm{C}$ por $0,5 \mathrm{~min}$;

- aumentar $3^{\circ} \mathrm{C} / \mathrm{min}$ até $230^{\circ} \mathrm{C}$, e permanecer por $2 \mathrm{~min}$;

$\diamond$ volume injetado: $2 \mu \mathrm{L}$

Da mesma forma citada anteriormente, uma corrida cromatográfica dos padrões isoladamente foi realizada, e a identificação e a quantificaçăo obtidas através de curva de calibração, altura versus concentração, de cada um dos padrōes (Tabela 18).

Tabela 18 - Concentração das soluções preparadas para a obtenção das curvas de calibração de 9 padrões de inseticidas organofosforados, por ordem de eluição nas condições cromatográficas estabelecidas.

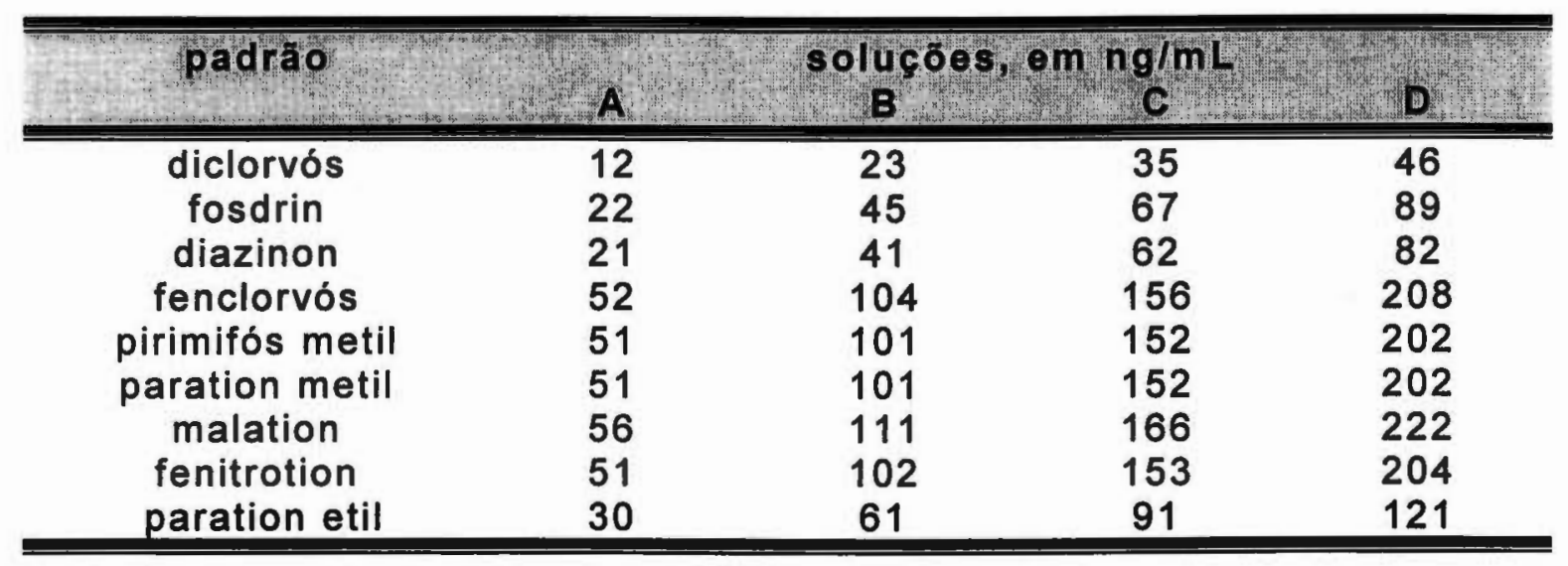


Colunas cromatográficas de diferentes polaridades foram selecionadas para a confirmação, se necessário, da identidade dos princípios ativos estudados.

4.6.4. MÉTODO PROPOSTO PARA A ANÁLISE DE METAMIDOFÓS EM AMOSTRAS DE TOMATE

- Solução-padrão

- A solução-padrão de metamidofós foi preparada em acetato de etila grau pesticida (Merck (B)). A solução-estoque foi diluida para a obtenção da solução de trabalho em acetato de etila.

- Extração de metamidofós em amostras de tomate

A técnica de extração adotada foi adaptada por Zavatti e Abakerli (1996) e compõe-se dos seguintes passos:

1. A $50 \mathrm{~g}$ da amostra de tomate, acompanhados das amostras de "branco" e adicionado, foram adicionados $15 \mathrm{~g}$ de cloreto de sódio e $100 \mathrm{~mL}$ de acetona. Após homogeneização por $3 \mathrm{~min}$, foram adicionados $75 \mathrm{~mL}$ de cloreto de metilieno, seguindo-se uma nova homogeneização e um repouso por alguns minutos. A fase superior foi concentrada em evaporador rotativo até cerca de $5 \mathrm{~mL}$, transferida para balão volumétrico de $10 \mathrm{~mL}$, e o volume aferido com acetona, para injeção no cromatógrafo a gás. O fluxograma do procedimento está ilustrado na Figura 7. 


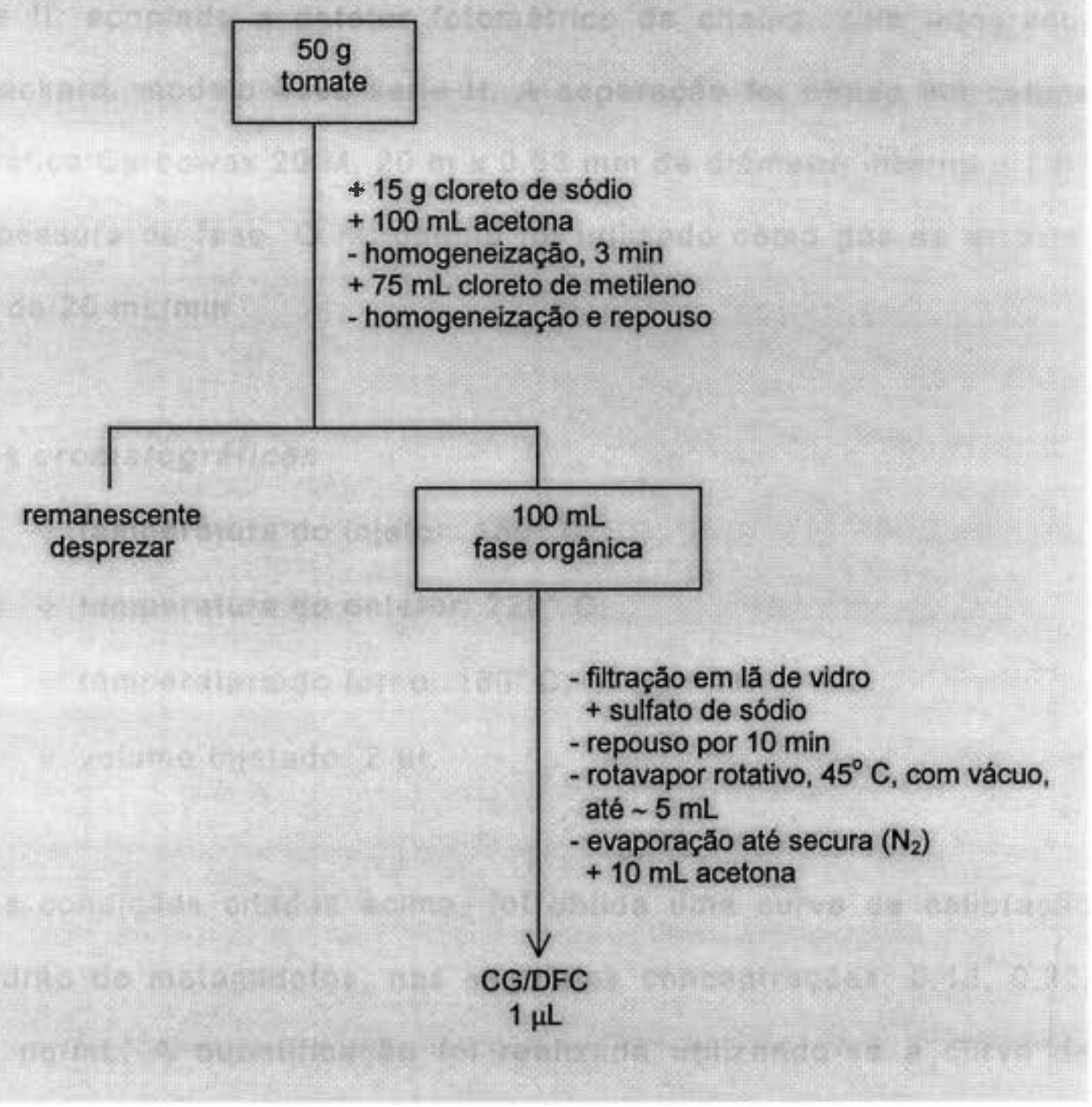

Figura 7 - Fluxograma do procedimento analítico usado na determinação de metamidofós em amostras de tomate. 


\section{- Análise por cromatográfica em fase gasosa}

Foi empregado um cromatógrafo a gás Hewlett Packard, modelo 5890-serie 11, acoplado a detetor fotométrico de chama, com integrador Hewlett Packard, modelo 3396-serie II. A separação foi obtida em coluna cromatográfica Carbowax $20 \mathrm{M}, 20 \mathrm{~m} \times 0,53 \mathrm{~mm}$ de diâmetro interno e 2,65 $\mu \mathrm{m}$ de espessura de fase. O nitrogênio foi utilizado como gás de arraste, com fluxo de $20 \mathrm{~mL} / \mathrm{min}$.

\section{Condições cromatográficas}

$\checkmark$ temperatura do injetor: $180^{\circ} \mathrm{C}$;

$\checkmark$ temperatura do detetor: $220^{\circ} \mathrm{C}$;

O temperatura do forno: $180^{\circ} \mathrm{C}$;

$\diamond$ volume injetado: $2 \mu L$

Nas condições citadas acima, foi obtida uma curva de calibração para o padrão de metamidofós, nas seguintes concentrações: $0,16,0,32$, 0,8 e $1,6 \mu \mathrm{g} / \mathrm{mL}$. A quantificação foi realizada utilizando-se a curva de calibração calculada pela área versus a concentração de metamidofós.

\subsection{5 - MÉTODO PROPOSTO PARA A ANÁLISE DE ETILENOTIURÉIA (ETU) EM} AMOSTRAS DE TOMATE

- Solução-padrão

A solução-padrão de etilenotiuréia foi preparada em metanol grau pesticida (Merck (B)), na concentração de $0,1 \%$. A solução de trabalho 
utilizada, na concentração de $10 \mu \mathrm{g} / \mathrm{mL}$, foi obtida por diluição em metanol grau pesticida (Merck (8)).

- Extração de ETU em amostras de tomate e purificação dos extratos obtidos

A técnica de extração adotada foi baseada nos trabalhos de Bolzoni e col. (1993) e Diserens (1991), com algumas adaptações. Após a homogeneização da amostra de tomate, com cerca de $10^{\circ} \mathrm{Brix}, 50 \mathrm{~g}$ foram pesados e filtrados em funil de Büchner e papel de filtro de $8 \mu \mathrm{m}$. O pH do filtrado aquoso foi ajustado com $\mathrm{NaOH} 5 \mathrm{~N}$ para $7,5 \mathrm{e}$, em seguida, filtrado, em série, usando-se filtros de 5 e $1,2 \mu \mathrm{m} ; 1 \mathrm{~mL}$ do filtrado foi transferido para a coluna contendo $6 \mathrm{~g}$ de extrelut (Merck (®), e, após 10 min, a ETU foi eluida com uma mistura de cloreto de metileno e metanol (98:2). O eluato foi evaporado até a secura em rotavapor a $30^{\circ} \mathrm{C}$ e corrente de nitrogênio. Metanol (1 mL) foi utilizado para ressuspender o extrato, sendo, então, transferido para a coluna de fase reversa $C_{18}$ (Seppak $(\mathbb{B})$, previamente condicionada; $3 \mathrm{~mL}$ de metanol foram utilizados para a eluição, e o eluato foi novamente evaporado, utilizando-se rotavapor a $30^{\circ} \mathrm{C}$ até um volume de aproximadamente $0,5 \mathrm{~mL}$ e corrente de nitrogênio até a secura. O extrato foi ressuspenso em $200 \mu \mathrm{L}$ de água/acetonitrila (98:2), e, após filtração em $0,45 \mu \mathrm{m}, 20 \mu \mathrm{L}$ foram utilizados para a análise cromatográfica. O fluxograma do procedimento da extração é mostrado na Figura 8 . 


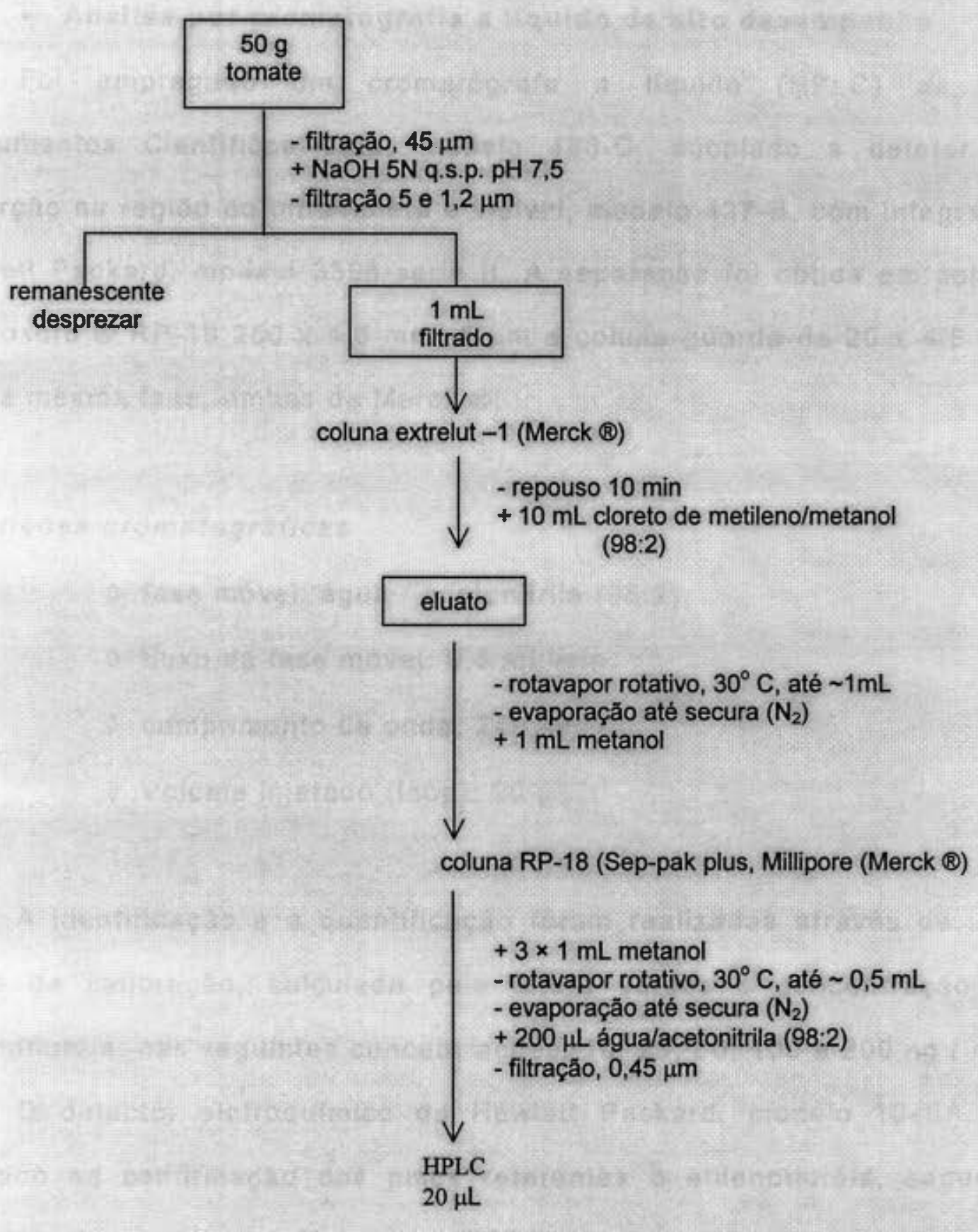

Figura 8 - Fluxograma do procedimento analítico usado na determinação de ETU em amostras de tomate. 
- Análise por cromatografia a liquido de alto desempenho

Foi empregado um cromatógrafo a líquido (HPLC) da CG Instrumentos Científicos Ltda, modelo 480-C, acoplado a detetor de absorção na região do ultravioleta e visivel, modelo 437-B, com integrador Hewlett Packard, modelo 3396-serie II. A separação foi obtida em coluna Lichrosorb $\otimes R P-18250 \times 4,6 \mathrm{~mm}, 5 \mu \mathrm{m}$ e coluna-guarda de $20 \times 4,6 \mathrm{~mm}$ com a mesma fase, ambas da Merck \&.

\section{Condições cromatográficas}

- fase móvel: água / acetonitrila (98:2);

$\diamond$ fluxo da fase móvel: $0,8 \mathrm{~mL} / \mathrm{min}$;

$\diamond$ comprimento de onda: $240 \mathrm{~nm}$;

$\checkmark$ Volume injetado (loop): $20 \mu \mathrm{L}$

A identificação e a quantificação foram realizadas através de uma curva de calibração, calculada pela altura versus a concentração de etilenotiuréia, nas seguintes concentrações: $10,25,50,100$ e $200 \mathrm{ng} / \mathrm{mL}$.

O detector eletroquimico da Hewlett Packard, modelo 1049A, foi utilizado na confirmação dos picos referentes à etilenotiuréia, segundo metodologia descrita por Maruyama (1994). 


\subsubsection{VALIDAÇÃO DOS MÉTODOS PROPOSTOS}

\subsubsection{1 - Especificidade}

A especificidade foi estabelecida através da determinação de amostras de tomate "branco" (Chasin e col., 1994), cultivados sem aplicação de praguicidas e provenientes de plantações de origens conhecidas.

\subsubsection{Preparação das curvas de calibração}

As curvas de calibração foram preparadas através de diluição das soluções de trabalho de modo a se obterem as concentrações descritas nas Tabelas 16,17 e 18 e em 4.6 .4 e 4.6.5.

A linearidade, estabelecida através da análise de regressão dos mínimos quadrados, foi avaliada através do coeficiente de correlação ( $r$ ) da curva, obtida pela projeção das concentrações de cada um dos padrões no eixo das abscissas e das suas áreas ou alturas correspondentes. O intervalo dinâmico (faixa linear utilizável) para cada um dos padrōes foi determinado com o coeficiente de correlação maior que 0,98 (Chasin e col., 1994). 


\subsubsection{Parâmetros de confiança dos métodos}

- Limites de detecção (LD) e de quantificação (LQ)

As concentrações estabelecidas como limites de detecção e quantificação foram obtidas através de adicionados dos padrões em macerados do "branco" de tomate, calculadas nas curvas de calibração (4.6.6.2). Foi considerada como limite de quantificação a menor concentração na qual a imprecisão (expressa pelo coeficiente de variação) foi inferior a $20 \%$ (Chasin e col., 1994).

\section{- Precisão}

A precisão foi avaliada através do coeficiente de variação (CV\%) entre as concentrações obtidas da análise de cinco amostras adicionadas de soluções de trabalho, com valores próximos ao limite de quantificação de cada método (Chasin e col., 1994).

- Recuperação

O cálculo da recuperação (\%) foi obtido por adição de padrão, em concentrações próximas ao limite de quantificação, a amostras de tomate "branco", quantificadas na curva de calibração (Chasin e col., 1994). 
5 - RESULTADOS 


\subsection{AVALIAÇÃO DOS TIPOS DE PRAGUICIDAS UTILIZADOS NO ESTADO DE PERNAMBUCO}

As informações sobre o uso de praguicidas, obtidas pela Secretaria Estadual de Agricultura em 1997 e EMATER-PE em 1990, 1991 e 1997. envolvendo diversos municipios do Estado, quando somadas, corresponderam a $76,9 \%$ da área total do Estado, ou seja, $76.089,1 \mathrm{~km}^{2}$, o que representa 113 dos 178 municipios existentes.

Os dados de cada município foram, inicialmente, agrupados por microrregião, para uma avaliação da abrangência dos mesmos e, posteriormente, distribuidos nas cinco mesorregiões do Estado. A Tabela 19 mostra a distribuição do número de praguicidas por grupos, citados em cada mesorregião, com as principais culturas praticadas. A análise possivel, no entanto, só pôde ser baseada no tipo de formulação citada, uma vez que, nos dados analisados neste trabalho, não constam concentração elou quantidade do produto utilizado, ou mesmo freqüência de aplicação para todos os municipios, o que inviabilizou o cálculo de principio ativo utilizado/hectare.

Foram citadas um total de 129 formulações comerciais diferentes em uso na agricultura para todo o Estado, das quais 26 não têm registro e apresentam produção e composição desconhecidas pelos usuários.

Os inseticidas organoclorados com referência de uso na agricultura foram o aldrin, dieldrin, endosulfan, dicofol, mirex. O produto comercial Polytrin (B) (profenofós + cypermetrina), indicado para uso apenas em culturas de algodão e café, foi citado em praticamente todas as regiões do Estado, sobretudo no Agreste, Sertão e São Francisco Pernambucano. 
Tabela 19 - Distribuição dos praguicidas citados, por grupos, segundo a divisão territorial do Estado e as principais culturas praticadas.

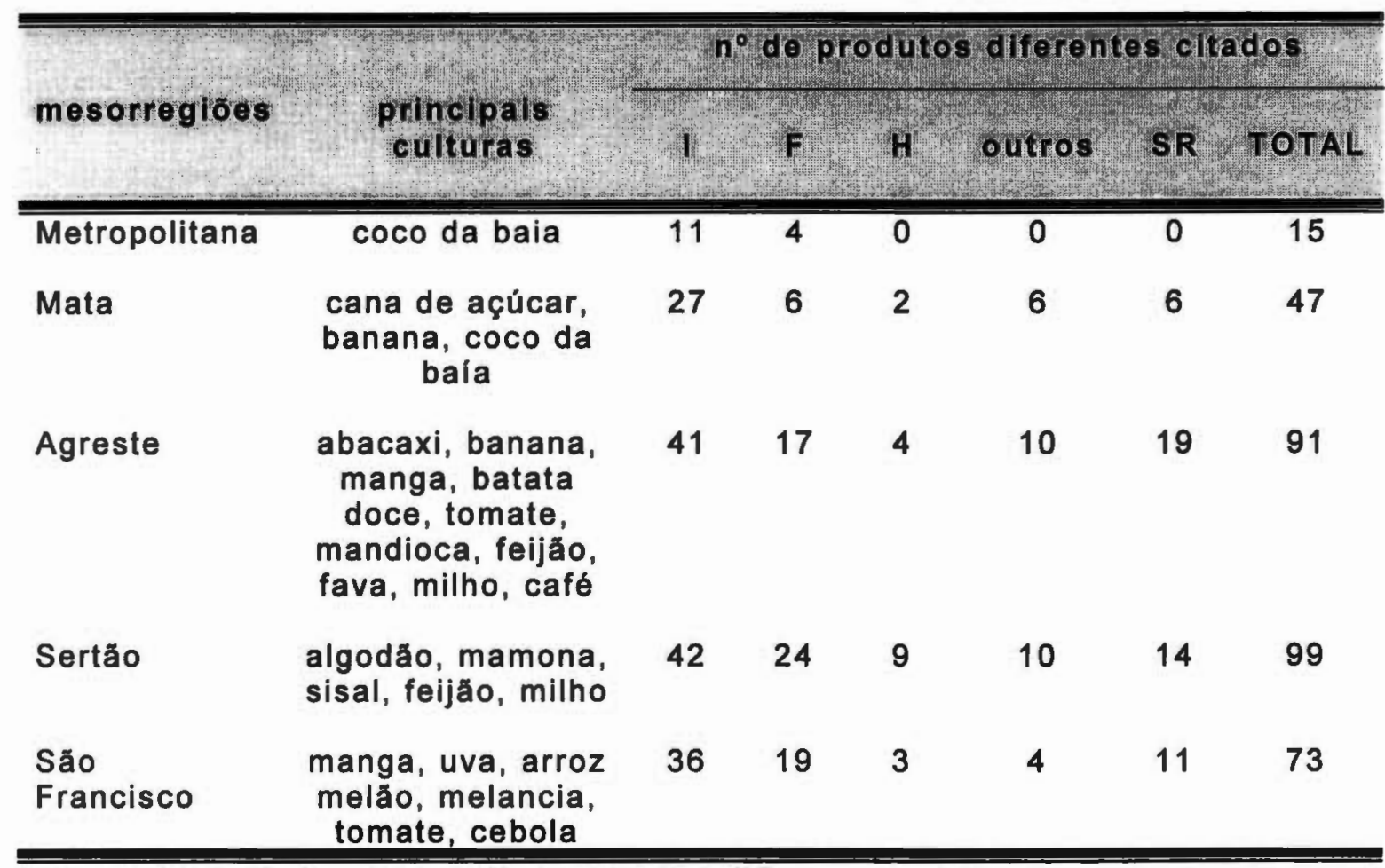

I: inseticidas; F: fungicidas; H: herbicidas; SR: sem registro

Elaborada a partir de levantamentos realizados pela Secretaria Estadual de Agricultura (1997) e EMATER-PE (1990, 1991 e 1997).

Dentre os inseticidas, os organofosforados são, de longe, os mais citados, respondem tipicamente por cerca de $50 \%$ da classe, estando os carbamatos e piretróides em segundo lugar.

Os fungicidas cúpricos, seguidos dos etilenobisditiocarbamatos, são mencionados em todas as regiōes indiscriminadamente, compondo, em média, $21,6 \%$ do total de praguicidas citados.

A Secretaria de Agricultura de Petrolina, em conjunto com a EMBRAPA/CPATSA, elabora, anualmente, um trabalho de acompanhamento das aplicaçōes de praguicidas pelos produtores do Perímetro Irrigado Senador Nilo Coelho. Cada cultura do perímetro contendo área cultivada/produtor é identificada segundo as pequenas 
propriedades, chamadas de campos ou subcampos, e estes, por sua vez, dentro do núcleo a que pertencem. Além do tipo de praguicida utilizado, com datas das aplicações dos produtos, consta a quantidade aplicada/hectare.

De posse desse registro, foi possivel transformar os dados em quantidade de principio ativo/hectare de tomate plantado, e, considerandose o número de aplicações, foi estimado o uso real de cada produto durante uma safra inteira. A distribuição dos princípios ativos por grupos (inseticidas, fungicidas, herbicidas e acaricidas) resultou nos dados apresentados na Tabela 20 , na qual são indicados os percentuais de uso para cada um dos grupos citados. Na Tabela 21 encontram-se listados os produtos mais citados para cada grupo.

Com relação aos produtos de origem biológica, no Projeto Senador Nilo Coelho, eles representam $68,9 \%$ contra $31,1 \%$ dos de origem química, considerando-se a quantidade total de princípios ativos empregados/hectare. Os produtos biológicos citados foram Dipel \& e Vertimec (8).

Dentre os fungicidas, responsáveis por $29,5 \%$ do total, a citação mais freqüente cabe aos fungicidas da classe dos etilenobisditiocarbamatos $(57,4 \%)$, seguidos pelos compostos cúpricos $(20,4 \%)$. Os compostos contendo enxofre responderam por apenas $7,3 \%$ do total de fungicidas, ficando $14,8 \%$ destinados ao uso de outros produtos de ação fúngica. 
Tabela 20 - Distribuição dos praguicidas de origem química, empregados na cultura de tomate industrial do perímetro irrigado do Projeto Senador Nilo Coelho.

\begin{tabular}{lc}
\hline \multicolumn{1}{c}{ produto químico } & percentagem de uso (\%) \\
\hline \hline inseticidas & 43,1 \\
carbamatos & 6,9 \\
piretróides & 3,9 \\
organofosforados & 29,5 \\
fungicidas & 9,4 \\
acaricidas & 7,2 \\
herbicidas & \\
\hline Elaborada a partir de dados fornecidos pela Secretaria de Agricultura de \\
Petrolina (março/95).
\end{tabular}

Tabela 21 - Produtos mais citados no perímetro irrigado do Projeto Senador Nilo Coelho, com os respectivos princípios ativos em parênteses e sua indicaçăo de uso (").

\begin{tabular}{|c|c|}
\hline grupo quimico & nome comerclal (princlpio ativo) \\
\hline $\begin{array}{l}\text { inseticidas } \\
\text { carbamatos }\end{array}$ & Carbaryl (carbaril), Lannate (metomil), Thiobel (cartap) \\
\hline piretróides & $\begin{array}{l}\text { Decis (deltametrina), Karate (lambdacyhalothrin), Pounce } \\
\text { (permetrina) }\end{array}$ \\
\hline fosforados & $\begin{array}{l}\text { Folidol (paration metilico), Nuvacron e Tamaron } \\
\text { (monocrotofós), Polytrin }{ }^{(*)} \text { (profenofós + cypermetrina) }\end{array}$ \\
\hline fungicida & $\begin{array}{l}\text { Benlate (benomil), Coprantol (cobre), Daconil (clorotalonil) } \\
\text { Dithane (mancozeb), Kumulus (enxofre) }\end{array}$ \\
\hline acaricidas & Omite (propargita) \\
\hline herbicidas & $\begin{array}{l}\text { Hebadox }{ }^{(")} \text { (pendimetalina), Podium }{ }^{(*)} \text { (fenoxaprop-p-etil), } \\
\text { Trifluralina (trifluralina) }\end{array}$ \\
\hline
\end{tabular}


5.1.1. TIPOS DE PRAGUICIDAS EMPREGADOS NAS SAFRAS DE TOMATE ESTUDADAS, SEGUNDO INFORMAÇŌES DOS PRODUTORES.

As Tabelas 22 e 23 mostram os praguicidas empregados nas safras de tomate estudadas do Projeto Senador Nilo Coelho e do Município de Camocim de São Félix. Essas informações foram fornecidas pelos próprios produtores das áreas onde foram efetuadas coletas de tomate para a análise de resíduos, através dos questionários:

- Projeto Senador Nilo Coelho

Tabela 22 - Praguicidas utilizados na safra de tomate de 1996 do Projeto Senador Nilo Coelho, segundo informações fornecidas pelos produtores através de questionário.

\begin{tabular}{|c|c|c|}
\hline $\begin{array}{l}n^{\circ} \mathrm{de} \\
\text { ordem }\end{array}$ & $\begin{array}{l}\text { amostra } \\
\text { (nucleollote) }\end{array}$ & produtos unilizados \\
\hline 1 & $\mathbf{N}_{7}-1086$ & $\begin{array}{c}\text { Derosal (F), Dipel (B), Funguran (Cu), Karate (IP), } \\
\text { Orthene(IF), Previcur (IC), Tamaron (IF), Vertimec (B) }\end{array}$ \\
\hline 2 & $N_{8}-1281$ & $\begin{array}{l}\text { Agrinose (Cu), Atabron (I), Derosal (F), Dipel (B), Karate } \\
\text { (IP), Orthene (IF), Previcur (IC), Tamaron (IF), Vertimec } \\
\text { (B) }\end{array}$ \\
\hline 3 & $N_{8}-1296$ & $\begin{array}{c}\text { Atabron (I), Dipel (B), Hamidop* (IF), Karate (IP), } \\
\text { Orthene (IF), Tamaron (IF), Vertimec (B) }\end{array}$ \\
\hline 4 & $N_{6}-682$ & $\begin{array}{c}\text { Bac-control }{ }^{*}(H), \text { Cartap (IC), Funguran (Cu), Karate }{ }^{*}(I P) \text {, } \\
\text { Tamaron (IF), Vertimec (B) }\end{array}$ \\
\hline 5 & $\mathbf{N}_{7}-1047$ & $\begin{array}{c}\text { Bac-control }^{*}(\mathrm{H}), \text { Cartap (IC), Dipel }\left.\right|^{*}(B), \text { Folisuper }^{*} \text { (IF), } \\
\text { Funguran (Cu), Hamidop (IF), Karate (IP), Nomolt (I), } \\
\text { Orthene (IF), Pounce* (IP), Stron (IF), Tamaron (IF), } \\
\text { Vertimec (B) }\end{array}$ \\
\hline 6 & $N_{8}-1325$ & Não informado \\
\hline
\end{tabular}


Continuação da Tabela 22.

\begin{tabular}{|c|c|c|}
\hline 7 & $N_{7}-1036$ & $\begin{array}{c}\text { Cartap" (IC), Dipel (B), Folisuper" (IF), Funguran" (Cu), } \\
\text { Karate (IP), Orthene (IF), Ridomil (F), Tamaron (IF), } \\
\text { Vertimec (B) }\end{array}$ \\
\hline 8 & $N_{7}-1081$ & $\begin{array}{l}\text { Dipel (B), Funguran * (Cu), Karate (IP), Nomolt* (I), } \\
\text { Orthene (IF), Stron" (IF), Tamaron (IF), Vertimec (B) }\end{array}$ \\
\hline 9 & $N_{9}-1137$ & $\begin{array}{c}\text { Confidor" (I), Dipel (B), Funguran" (Cu), Fusilade (H), } \\
\text { Karate (IP), Mycoshield" (A), Orthene (IF), } \\
\text { Ridomil" (F), Stron" (IF), Vertimec (B) }\end{array}$ \\
\hline 10 & $N_{4}-013$ & $\begin{array}{c}\text { Dipel (B), Karate (IP), Orthene (IF), Tamaron (IF), } \\
\text { Vertimec (B) }\end{array}$ \\
\hline 11 & $N_{5}-417$ & $\begin{array}{c}\text { Dipel (B), Karate (IP), Orthene (IF), Recop* (Cu), } \\
\text { Tamaron (IF), Vertimec (B) }\end{array}$ \\
\hline 12 & $N_{5}-418$ & $\begin{array}{c}\text { Atabron "(I), Dipel (B), Karate (IP), Nomolt* (I), Orthene } \\
\text { (IF), Recop* (Cu), Tamaron (IF), Vertimec (B) }\end{array}$ \\
\hline 13 & $N_{4}-031$ & $\begin{array}{c}\text { Bac-control" (H), Funguran (Cu), Orthene* (IF), } \\
\text { Pounce }^{*}(\mathrm{IP}) \text {, Thiobel }\left.\right|^{*}(\mathrm{IC}) \text {, Vertimec }(\mathrm{B})\end{array}$ \\
\hline 14 & $\mathrm{~N}_{4}-049$ & $\begin{array}{c}\text { Bac-control* (H), Cartap (IC), Cobre*, Hamidop* (IF), } \\
\text { Pounce* (IP), Tamaron (IF), Vertimec (B) }\end{array}$ \\
\hline 15 & $N_{4}-076$ & $\begin{array}{l}\text { Bac-control }{ }^{*}(H) \text {, Funguran }(\mathrm{Cu}) \text {, Orthene }(I F) \text {, } \\
\text { Pounce* }(I P) \text {, Tamaron (IF), Thiobel }(I C) \text {, Vertimec (B) }\end{array}$ \\
\hline 16 & $N_{1}-484$ & $\begin{array}{c}\text { Dipel (B), Karate (IP), Orthene (IF), Stron* (IF), } \\
\text { Tamaron (IF), Vertimec (B) }\end{array}$ \\
\hline 17 & $N_{1}-510$ & $\begin{array}{c}\text { Dipel (B), Karate (IP), Orthene (IF), Stron* (IF), } \\
\text { Tamaron (IF), Vertimec (B) }\end{array}$ \\
\hline 18 & $N_{2}-569$ & Dipel (B), Karate (IP), Nomolt ${ }^{*}$ (I), Orthene (IF) \\
\hline 19 & $N_{10}-1446$ & Dipel (B), Orthene (IF), Tamaron (IF), Vertimec (B) \\
\hline 20 & $N_{10}-1452$ & $\begin{array}{l}\text { Derosal (F), Dipel (B), Karate (IP), Nomolt }{ }^{*} \text { (I), Orthene } \\
\text { (IF), Previcur (IC), Tamaron (IF), Vertimec (B) }\end{array}$ \\
\hline 21 & $N_{11}-841$ & $\begin{array}{c}\text { Dipel (B), Karate (IP), Orthene (IF), Tamaron (IF), } \\
\text { Vertimec (B) }\end{array}$ \\
\hline 22 & $N_{10}-1435$ & $\begin{array}{c}\text { Bac-control* (H), Cartap (IC), Hamidop* (IF), Pounce* } \\
\text { (IP), Thiobel } I^{*}(I C), \text { Vertimec (B) }\end{array}$ \\
\hline 23 & $N_{11}-853$ & Bac-control* $(H)$, Hamidop (IF), Tamaron (IF), Vertimec (B) \\
\hline 24 & $N_{11}-827$ & Bac-control ${ }^{*}(H)$, Pounce* (IP), Tamaron (IF), Vertimec (B) \\
\hline 25 & $N_{11}-887$ & $\begin{array}{c}\text { Bac-control" (H), Elsan * (IF), Hamidop* (IF), Karate (IP), } \\
\text { Orthene (IF), Pounce* (IP), Vertimec (B) }\end{array}$ \\
\hline 26 & $N_{11}-890$ & $\begin{array}{c}\text { Dipel (B), Karate (IP), Funguran }{ }^{*}(\mathrm{Cu}) \text {, Orthene (IF), } \\
\text { Stron (IF), Tamaron (IF), Vertimec (B) }\end{array}$ \\
\hline
\end{tabular}


Continuação da Tabela 22.

$\mathrm{N}_{11}-909 \quad$ Dipel (B), Karate (IP), Funguran (Cu), Orthene (IF),
Tamaron (IF), Vertimec (B)

: produto não fornecido pela empresa contratada

(I): inseticida; (IF): inseticida organofosforado; (IC): inseticida carbamato; (IP): inseticida piretróide; $(F)$ : fungicida; $(H)$ : herbicida; $(C u)$ : produto à base de cobre; (B): produto de origem biológica; (A): antibiótico.

O uso de diferentes formulações comerciais por um mesmo produtor variou de 4 a 13 , porém o valor médio foi de 6,8 produtos/cultura. Os produtores, juntos, citaram um total de 25 praguicidas diferentes, dos quais $56 \%$ eram inseticidas e, dentre os inseticidas, os organofosforados responderam por um número maior, $42,8 \%$, sendo o Tamaron (8) (metamidofós) e o Orthene (acefato) os principais produtos.

O uso de pelo menos um produto de origem biológica foi citado por todos os produtores, tendo sido o Vertimec \& o produto biológico mais citado, dentre todos os praguicidas, e empregado por 25 dos 26 produtores que forneceram esse dado. Dois deles, o Confidor (8) Bac-control (\&, não constam como produtos registrados, segundo a Coordenação de Fiscalização de Agrotóxicos do Ministério da Agricultura-AGROFIT(1997). 


\section{- Município de Camocim de São Félix}

Tabela 23 - Praguicidas utilizados na safra de tomate de 1996/97 do Município de Camocim de São Félix, segundo informação fornecida pelos produtores através de questionário.

\begin{tabular}{|c|c|c|}
\hline$\frac{n^{\circ} d e}{\text { ordem }}$ & $\begin{array}{l}\text { amostra } \\
\text { (tazendalsitio) }\end{array}$ & produtos utilizados \\
\hline 1 & Boa Esperança & $\begin{array}{c}\text { Baytroid (IP), Cobose, Dithane (F), Karate (IP), } \\
\text { Manzate (F), Vertimec (B) }\end{array}$ \\
\hline 2 & Trés Marias & $\begin{array}{c}\text { Curacron (IF), Decis (IP), Karate (IP), Talcord (IP), } \\
\text { Vertimec (B) }\end{array}$ \\
\hline 3 & Trés Marias & Dithane (F), Karate (IP), Thiodan (C) \\
\hline 4 & Boa Esperança & Agrimicina (A), Ambush (IP), Karate (IP), Ridomil (F) \\
\hline 5 & $\begin{array}{l}\text { Mondé dos } \\
\text { Cabrais }\end{array}$ & Năo informado \\
\hline 6 & $\begin{array}{l}\text { Mondé dos } \\
\text { Cabrais }\end{array}$ & Năo informado \\
\hline 7 & Alagado & $\begin{array}{c}\text { Ambush (IP), Atabron (I), Curzate, Decis (IP), } \\
\text { Funguran (Cu), Karate (IP), Manzate (F), Match (I), } \\
\text { Meltron, Nomolt (I), Reconil (Cu), Recop (Cu), } \\
\text { Ridomil (F). Trigard (I), Vertimec (B) }\end{array}$ \\
\hline 8 & Cruz de Rajada & $\begin{array}{l}\text { Cartap (IC), Cupravit (Cu), Cymbush (IP), Dithane (F), } \\
\text { Elsan (IF), Folicur (F), Funguran (Cu), Karate (IP), } \\
\text { Match (I), Recop (Cu), Ridomil (F), Talcord (IP) }\end{array}$ \\
\hline 9 & $\begin{array}{l}\text { Lagoa do } \\
\text { Ramalho }\end{array}$ & $\begin{array}{l}\text { Ambush (IP), Baytroid (IP), Cartap (IC), Dithane (F), } \\
\text { Elsan (IF, Funguran (CU), Karate (IP), Match (I), } \\
\text { Orthene (IF), Orthocide (F), Ridomil (F), Thiobel (IC) }\end{array}$ \\
\hline 10 & Boa Vista & $\begin{array}{c}\text { Ambush (IP), Baytroide (IP), Dithane (F), Elsan (IF), } \\
\text { Folicur (F), Funguran (Cu), Karate (IP), Match (I) }\end{array}$ \\
\hline 11 & Boa Vista & $\begin{array}{c}\text { Ambush (IP), Benlate (F), Decis (IP), Folidol (IF), } \\
\text { Funguran (Cu), Karate (IP), Match (I), Orthocide (F), } \\
\text { Recop (Cu), Tamaron (IF), Thiobel (IC) }\end{array}$ \\
\hline 12 & Palmeira & $\begin{array}{l}\text { Baytroide (IP), Cartap (IC), Elsan (IF), Folicur (F), } \\
\text { Folidol (IF), Funguran (CU), Karate (IP), Match (I) }\end{array}$ \\
\hline 13 & $\begin{array}{l}\text { Lagoa do } \\
\text { Ramalho }\end{array}$ & $\begin{array}{c}\text { Decis (IP), Dithane (F), Kelthane (C), Karate (IP), } \\
\text { Manzate (F), Match (I), Thiobel (IC) }\end{array}$ \\
\hline 14 & $\begin{array}{l}\text { Lagoa do } \\
\text { Ramalho }\end{array}$ & Năo informado \\
\hline $\begin{array}{l}15 \\
16 \\
17\end{array}$ & $\begin{array}{l}\text { Mocós } \\
\text { Mocós } \\
\text { Mocós }\end{array}$ & 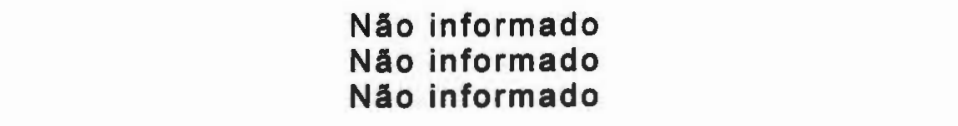 \\
\hline 18 & Mocós & $\begin{array}{c}\text { Dithane (F), Elsan (IF), Karate (IP), Orthocide (F), } \\
\text { Talcord (IP), Tamaron (IF) }\end{array}$ \\
\hline
\end{tabular}




\section{Continuação da Tabela 23.}

\begin{tabular}{|c|c|c|}
\hline 19 & $\begin{array}{l}\text { Nossa Sra do } \\
\text { Carmo }\end{array}$ & $\begin{array}{c}\text { Dithane (F), Elsan (IF), Karate (IP), Sumidan (IP), } \\
\text { Talcord (IP), Tamaron (IF) }\end{array}$ \\
\hline 20 & $\begin{array}{l}\text { Lagoa do } \\
\text { Ramalho }\end{array}$ & $\begin{array}{c}\text { Baytroide (IP), Dithane (F), Elsan (IF), Funguran (CU), } \\
\text { Karate (IP), Kelthane (C), Lannate (IC), Sumidan (IP), } \\
\text { Talcord (IP), Vertimec (B) }\end{array}$ \\
\hline 21 & Cruz de Rajada & $\begin{array}{c}\text { Ambush (IP), Cartap (IC), Dithane (F), Elsan (IF), } \\
\text { Karate (IP), Orthocide (F), Sumidan (IP), Talcord (IP), } \\
\text { Tamaron (IF) }\end{array}$ \\
\hline 22 & Cruz de Rajada & $\begin{array}{c}\text { Ambush (IP), Benlate (F), Cartap (IC), Decis (IP), } \\
\text { Elsan (IF), Folidol (IF), Funguran (Cu), Karate (IP), } \\
\text { Match (I), Talcord (IP) }\end{array}$ \\
\hline 23 & $\begin{array}{l}\text { Lagoa do } \\
\text { Ramalho }\end{array}$ & $\begin{array}{l}\text { Baytroide (IP), Decis (IP), Dithane (F), Elsan (IF), } \\
\text { Funguran (Cu), Karate (IP), Kelthane (C), Lannate (IC), } \\
\text { Sumidan (IP), Talcord (IP), Tamaron (IF), Vertimec (B) }\end{array}$ \\
\hline 24 & $\begin{array}{l}\text { Lagoa do } \\
\text { Ramalho }\end{array}$ & $\begin{array}{c}\text { Ambush (IP), Baytroide (IP), Cartap (IC), Dithane (F), } \\
\text { Elsan (IF), Funguran (Cu), Karate (IP), Match (I) } \\
\text { Orthocide (F), Talcord (IP), Tamaron (IF) }\end{array}$ \\
\hline 25 & Palmeiras & $\begin{array}{c}\text { Ambush (IP). Decis (IP), Formicida shell (C), Karate (IP), } \\
\text { Simirex. Tamaron (IF) }\end{array}$ \\
\hline 26 & Palmeiras & $\begin{array}{c}\text { Ambush (IP), Baytroide (IP), Benlate (F), Cartap (IC), } \\
\text { Dithane (F), Folicur (F), Funguran (CU), Karate (IP), } \\
\text { Manzate (F), Match (I), Sumidan (IP), Talcord (IP), } \\
\text { Tamaron (IF) }\end{array}$ \\
\hline 27 & Pacas 11 & Decis (IP), Funguran ( $\mathrm{Cu}$ ), Manzate (F), Vertimec (B) \\
\hline 28 & Pacas 11 & $\begin{array}{c}\text { Curacron (IF), Folidol (IF), Manzate (F), Tamaron (IF), } \\
\text { Vertimec (B) }\end{array}$ \\
\hline 29 & Pacas 11 & $\begin{array}{c}\text { Curacron (IF), Hamidop (IF), Manzate (F), Match (I), } \\
\text { Tamaron (IF), Vertimec (B) }\end{array}$ \\
\hline 30 & Pacas II & $\begin{array}{c}\text { Curacron (IF), Hamidop (IF), Manzate (F), Match (I), } \\
\text { Tamaron (IF), Vertimec (B) }\end{array}$ \\
\hline 31 & Pacas $\|$ & Decis (IP), Funguran (Cu), Manzate (F), Vertimec (B) \\
\hline 32 & Mocós & $\begin{array}{c}\text { Cuprozeb (Cu), Decis (IP), Dithane (F), Hamidop (IF), } \\
\text { Karate (IP), Manzate (F), Meothrin (IP), Nomolt (I), } \\
\text { Piredan (IP) }\end{array}$ \\
\hline
\end{tabular}

(1): inseticida; (IF): inseticida organofosforado; (IC): inseticida carbamato; (IP): inseticida piretróide; (C): inseticida organoclorado; $(F)$ : fungicida; $(H)$ : herbicida; $(\mathrm{Cu})$ : produto à base de cobre; (B): produto de origem biológica; (A): antibiótico. 
Dos 32 produtores selecionados, houve perda de 6 respostas, e alguns declararam o uso de esterco de galinha, apenas.

A utilização de diferentes formulações comerciais por um mesmo produtor variou de 3 a 15 , com o valor médio de 8 produtos/cultura.

Foram citados um total de 42 praguicidas diferentes, dos quais $59 \%$ eram inseticidas $e$, dentre os inseticidas, os piretróides responderam por um número maior. O uso de um produto de origem biológica foi citado por apenas 10 produtores.

Dois inseticidas organoclorados foram mencionados, Thiodan (endosulfan), com uso restrito e mediante prescrição de receita agronômica, para culturas de algodão, café, cacau e soja, e Kelthane (®) (dicofol), indicado para culturas de cítricos e algodão. O Formicida Shell $₫$ (clorfenvinfós) também foi utilizado, apesar de ter uso destinado exclusivamente contra formigas, com aplicação direta no canal do formigueiro, assim como o inseticida organofosforado Curacron (B) (profenofós), de emprego autorizado para soja, café, milho e algodão.

Um dos produtos tem seu registro cancelado (Curzate (B), e outros 3 , não permitem identificação, ou seja, são de origem desconhecida (simirex, cobose e meltron). 
5.2. LEVANTAMENTO DE DADOS SÓCIO-AMBIENTAIS E DE MORBIDADE REFERIDA EM TRABALHADORES ENVOLVIDOS NA CULTURA DO TOMATE

\subsubsection{TOMATE INDUSTRIAL - PROJETO SENADOR NILO COELHO}

Em 14 dos 27 campos estudados com plantação de tomate, a aplicação de praguicidas foi realizada por pessoas contratadas pelos proprietários, utilizando-se, para isso, o equipamento de maior uso na região, o pulverizador costal. Em apenas três produções, foi citado o uso pelos proprietários de tratores para esse fim.

As embalagens vazias dos produtos após o uso eram enterradas no próprio lote ou na área de sequeiro (37\%) ou eram armazenadas para posterior queima $(18,5 \%)$ ou não tinham um destino estabelecido previamente $(44,5 \%)$.

Cerca de $80 \%$ dos aplicadores que manuseavam praguicidas há mais de cinco anos possuiam pouco conhecimento sobre os equipamentos de proteção individual, e, dentre os poucos incômodos relatados, estavam a tontura, a náusea e a dor de cabeça.

Apenas três aplicadores afirmaram que se submetem a exames de saúde periódicos, e, dos sete que informaram ter tido problemas de saúde por exposição a praguicidas, quatro necessitaram de atendimento médico, havendo uma internação hospitalar. No entanto, apenas um caso foi registrado como acidente de trabalho. 


\subsubsection{TOMATE DE MESA - CAMOCIM DE SÃO FÉLIX}

Diferentemente do Projeto Senador Nilo Coelho onde já existiam dados sobre o processo produtivo do tomate, em Camocim de São Félix somente foi possivel obter informações através do questionário aplicado. cujos resultados são apresentados a seguir:

\section{Condições sócio-ambientais}

- Na safra de $1996 / 1997$, houve uma predominância de homens $(70,1 \%)$ na população de trabalhadores rurais da plantação de tomate de Camocim de São Félix, dos quais $26,0 \%$ eram menores de 18 anos, sendo a idade média observada de 27 anos;

- quanto à escolaridade, $41,0 \%$ eram analfabetos e $41,0 \%$ possuiam o primário incompleto. Apenas $30,9 \%$ dos casos estudados tinham acesso à água tratada, sendo que, dentre as fontes de abastecimento, o poço se apresentou como a mais importante $(46,7 \%)$;

- com relação ao tipo de contrato de trabalho, a modalidade diarista era predominante $(47,2 \%)$, seguida pela de produção $(22,9 \%)$ e pela de meeiro $(18,8 \%)$; os assalariados correspondiam apenas a $2,8 \%$;

- a renda familiar observada foi menos de 2 salários mínimos para $57 \%$ das familias, e $86 \%$ possuiam renda familiar inferior a 3 salários mínimos. Com relação ao salário individual, $57 \%$ recebiam menos de 1 salário minimo, e $40,5 \%$ recebiam de 2 a 3 salários minimos; $75 \%$ tinham de 2 a 5 membros da familia trabalhando na lavoura; 
- apenas $4,5 \%$ dos trabalhadores rurais trabalhavam até 8 horas, a maioria, $72,5 \%$, trabalhava de 8 a 10 horas diárias, e $20 \%$, mais de 10 horas;

- foi registrada a precariedade previdenciária e de direitos trabalhistas dos lavradores envolvidos na produção de tomate, uma vez que apenas $1,3 \%$ possuiam registro em carteira de trabalho, e $97,8 \%$ não possuiam cobertura previdenciária; apenas $15,4 \%$ eram sindicalizados;

- com relação à função exercida, $71,4 \%$ dos trabalhadores participaram de todas as etapas do processo de produção, exceto a pulverização; $18,4 \%$ trabalharam em todas as atividades e também na pulverização, e $10,2 \%$ tiveram como única atividade a pulverização; dessa forma, o total de trabalhadores que tiveram contato diretamente com praguicidas nesse cultivo foi de $28,6 \%$, dos quais $34,2 \%$ estavam desempenhando essa atividade há mais de 10 anos;

- no que se refere aos equipamentos utilizados na aplicação de praguicidas, $34,1 \%$ das pessoas entrevistadas desconheciam o tipo de equipamento utilizado; o uso de bomba a motor foi o meio mais empregado em $53,2 \%$ dos casos, e os outros instrumentos, como bomba manual/costal, pistola/caneta, são de uso pouco freqüente;

- a maioria dos entrevistados usualmente não observou a direção dos ventos no momento da aplicação do produto; quanto ao uso do equipamento de proteção individual (EPI), 64,2\% revelaram não utilizá10;

- a forma de obtenção do praguicida foi, quase sempre, através do comércio local e nas cooperativas; no entanto, cerca de $28,0 \%$ foram comprados em outros municipios ou diretamente de vendedores; 
apenas $13,0 \%$ informaram ter recebido instruções sobre o uso por ocasião da última compra, e o Receituário Agronômico foi utilizado em apenas $36,0 \%$ da negociação; foi significante 0 número de trabalhadores $(30 \%)$ que ignoravam o que seja esse instrumento de compra e orientação;

- $45,8 \%$ não respeitaram o tempo de carência após a aplicação dos praguicidas, e $18,3 \%$ ignoravam sua necessidade;

- a maioria das embalagens $(54,4 \%)$ foi deixada no campo ou teve outro destino inadequado, como o depósito de lixo comum. Constatou-se que $1,9 \%$ dos entrevistados mencionaram reaproveitamento das embalagens;

- as roupas de trabalho eram lavadas, em $75,2 \%$ dos casos, no ambiente doméstico; $24,8 \%$ revelaram lavá-las em açudes, cacimbas e rios;

- quanto às lavagens dos equipamentos de aplicação, 57,0\% mencionaram que foram realizadas no campo (local de trabalho); não houve qualquer referência à tríplice lavagem.

\section{Morbidade referida}

- $13,2 \%$ já sofreram algum tipo de intoxicação devido ao praguicida utilizado na lavoura, a maioria necessitando socorro médico; 45 dos 159 relataram mal-estar durante a aplicação do produto;

- os problemas relacionados com o sistema imunológico apresentaram maior número de queixas $(36,4 \%)$ : prurido na pele, olhos e nariz ou febre freqüente; o sintoma relacionado com o sistema ósteomuscular de maior ocorrência foi o de dor nas articulações $(35,8 \%)$, enquanto os sistemas nervoso central e periférico foram responsáveis por $32,5 \%$ das 
queixas: tontura, formigamento nos membros superiores, alterações de sono e vômitos;

- com relação ao tratamento realizado por aqueles que sofreram intoxicação por praguicidas, foram relatados: ingestão de antibióticos, leite, ovo com fumo, comprimido, injeção e reza;

- os entrevistados relataram ter conhecimento de alguns mecanismos de proteção contra a exposição ao praguicida, como não ficar na direção do vento durante a aplicação e beber leite ou caldo de feijão; $40,9 \%$ das pessoas revelaram nada fazer;

- $70,6 \%$ das mulheres entrevistadas relataram perda de feto, e $39,4 \%$ revelaram ter perdido um filho com menos de um ano de vida.

\subsection{VALIDAÇÃO DOS MÉTODOS ANALITICOS UTILIZADOS}

\section{- Especificidade}

As Figuras 9, 10, 11, 12 e 13 mostram os cromatogramas de tomate "branco", enriquecidos com 18 inseticidas organoclorados, endosulfan ( $\alpha$, $\beta$ e sulfato), 9 inseticidas organofosforados, metamidofós e etilenotiuréia (ETU), respectivamente. A Figura 14 mostra o cromatograma obtido por cromatografia a liquido (HPLC) e detector eletroquímico, em adicionado de amostra de tomate "branco", utilizado para a confirmação da presença de ETU e propilenotiuréia (PTU). 


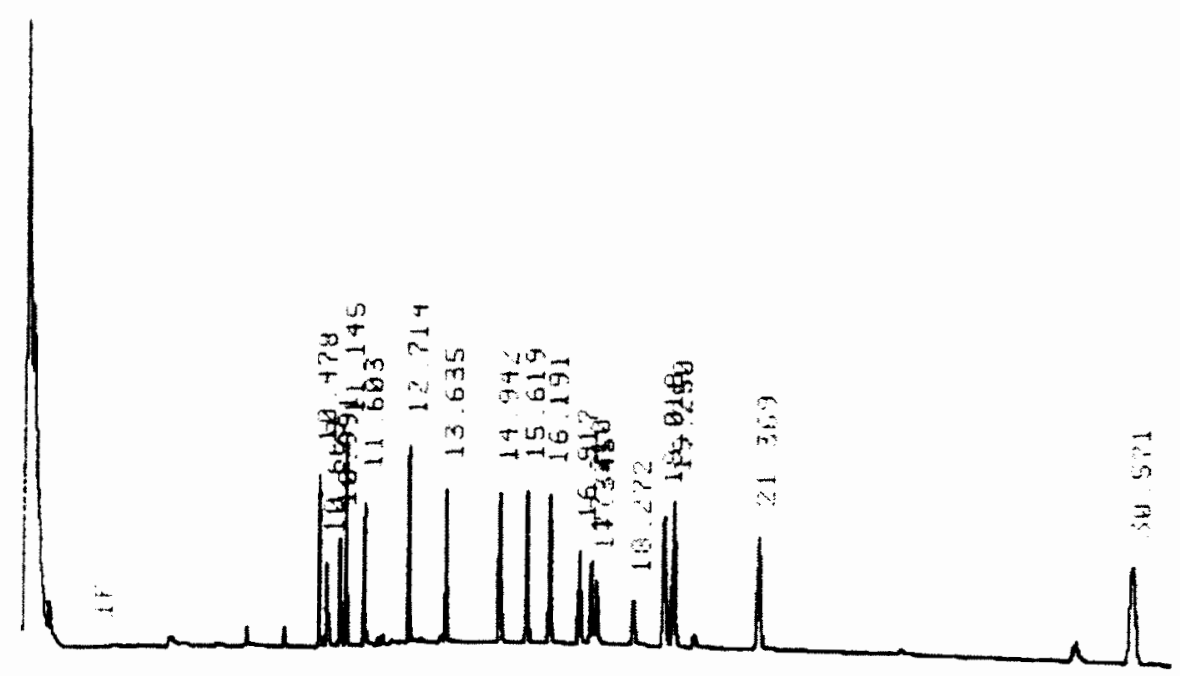

Figura 9 - Cromatograma de tomate "branco" enriquecido com 18 inseticidas organoclorados com concentrações entre 2,1 a $21,2 \mu \mathrm{g} / \mathrm{kg}$ e seus respectivos tempos de retenção em minutos.

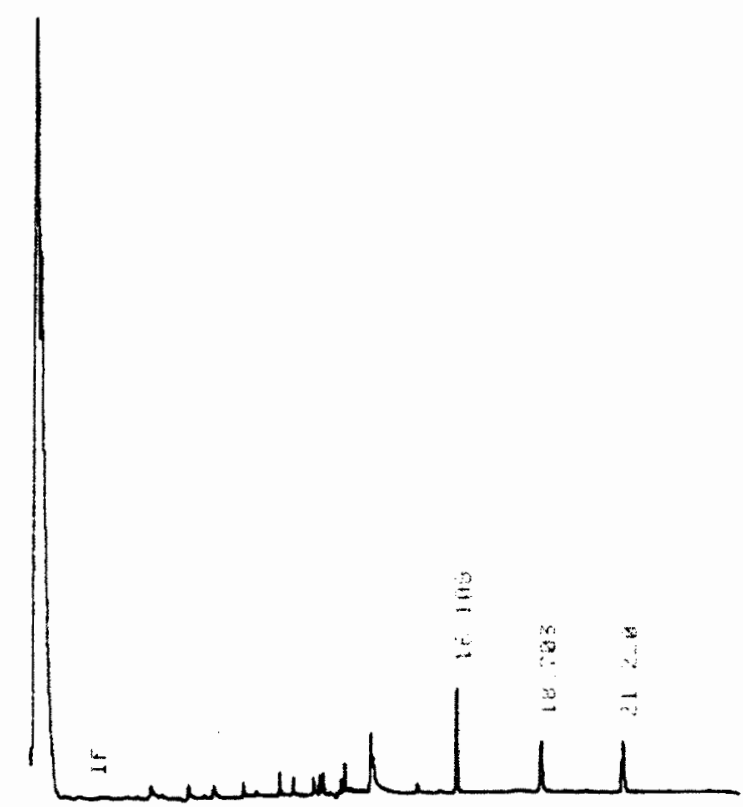

Figura 10 - Cromatograma de tomate "branco" enriquecido com endosulfan ( $\alpha, \beta$ e sulfato) com concentrações entre 4,0 a $6,1 \mu \mathrm{g} / \mathrm{kg}$ e seus respectivos tempos de retenção em minutos. 


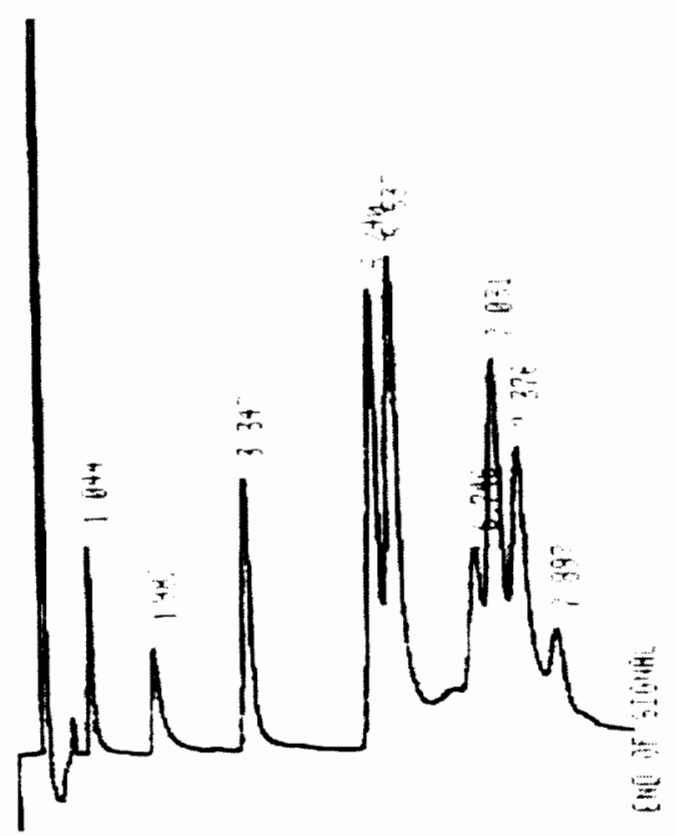

Figura 11 - Cromatograma de tomate "branco" enriquecido com 9 inseticidas organofoforados com concentrações entre 0,02 a $0,1 \mathrm{mg} / \mathrm{kg}$ e seus respectivos tempos de retenção em minutos.

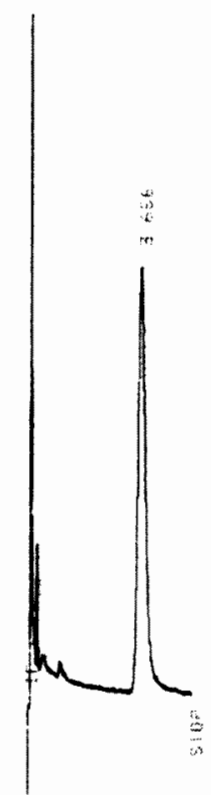

Figura 12 - Cromatograma de tomate "branco" enriquecido com 0,06 $\mathrm{mg} / \mathrm{kg}$ de metamidofós e seu respectivo tempo de retenção em minutos. 


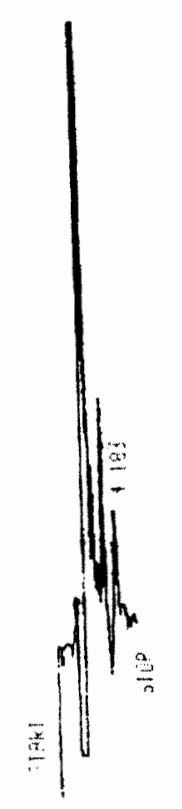

Figura 13 - Cromatograma de tomate "branco" enriquecido com 30 $\mu g / k g$ de ETU e seu respectivo tempo de retenção em minutos.

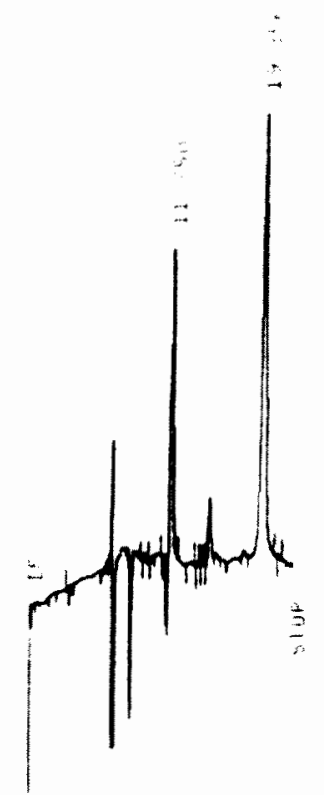

Figura 14 - Cromatograma de tomate "branco" enriquecido com ETU e PTU (propilenotiuréia), obtido por cromatografia a líquido (HPLC) e detector eletroquímico e seus respectivos tempos de retenção em minutos. 
- Curvas de calibração

As representações gráficas das curvas de calibração obtidas para um padrão de cada grupo estudado estão expressas nas Figuras 15, 16, 17 , 18 e 19.

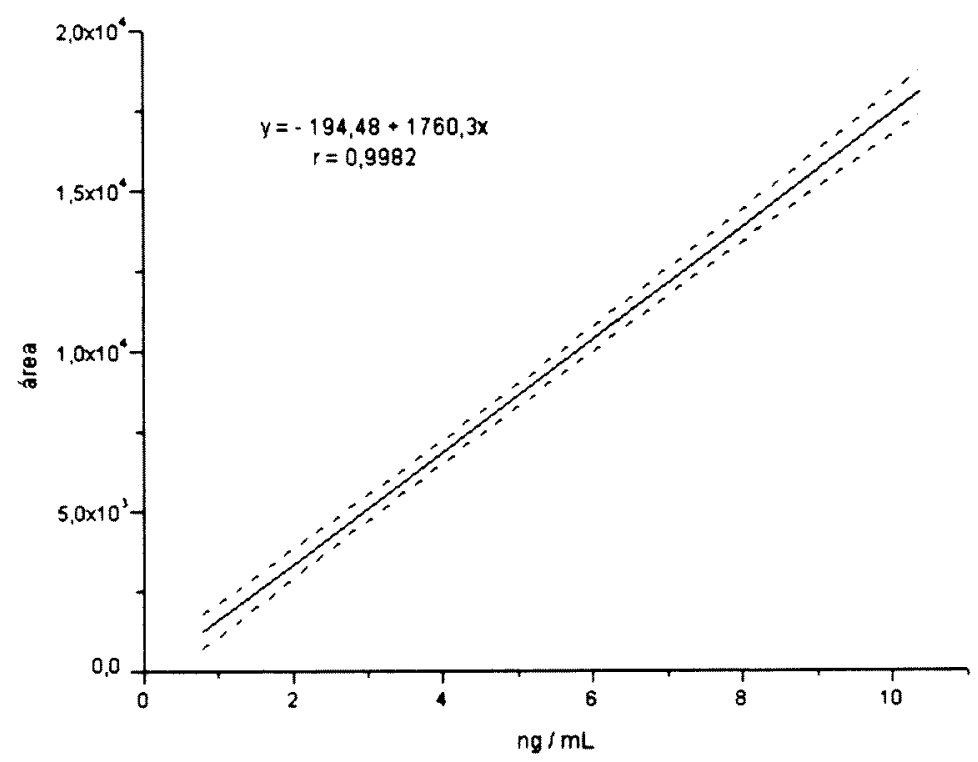

Figura 15 - Representação gráfica da curva de calibração obtida para a faixa de concentração de 1,24 a $9,96 \mathrm{ng} / \mathrm{mL}$ de $\alpha-\mathrm{HCH}$. 


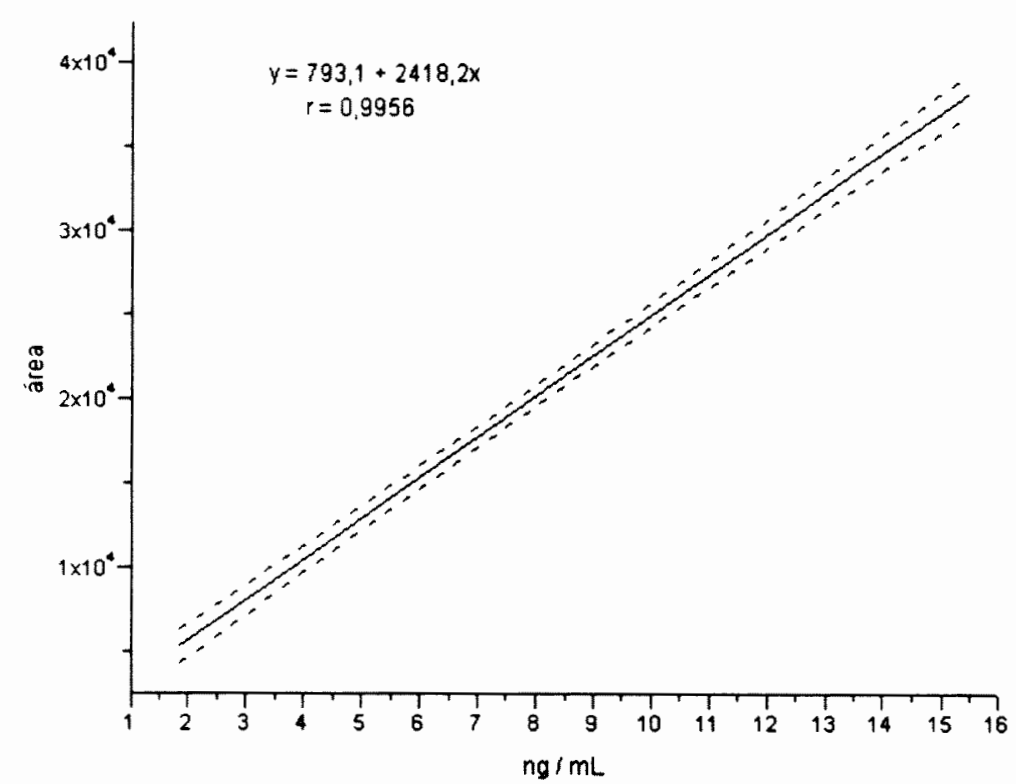

Figura 16 - Representação gráfica da curva de calibração obtida para a faixa de concentração de 2,5 a $14,9 \mathrm{ng} / \mathrm{mL}$ de $\alpha$-endosulfan.

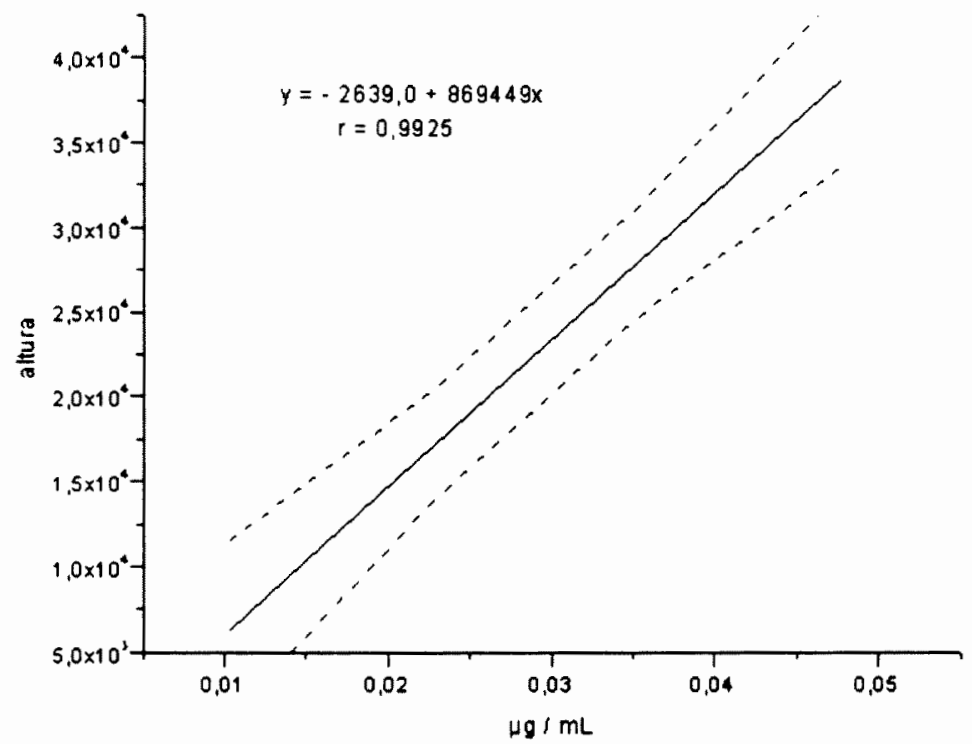

Figura 17 - Representação gráfica da curva de calibração obtida para a faixa de concentração de 12 a $46 \mathrm{ng} / \mathrm{mL}$ de diclorvós. 


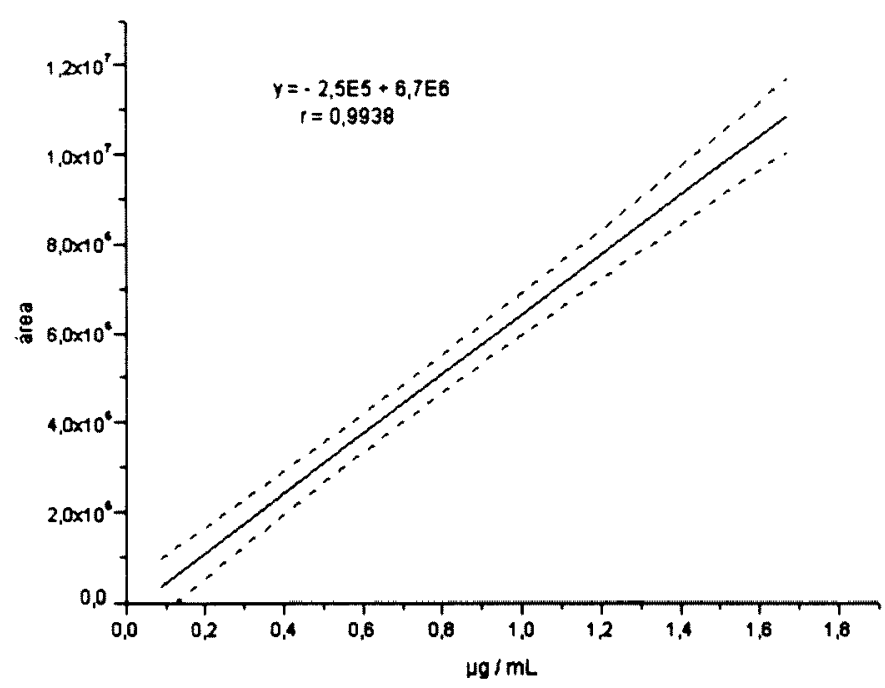

Figura 18 - Representação gráfica da curva de calibração obtida para a faixa de concentração de 0,16 a $1,6 \mu \mathrm{g} / \mathrm{mL}$ de metamidofós.

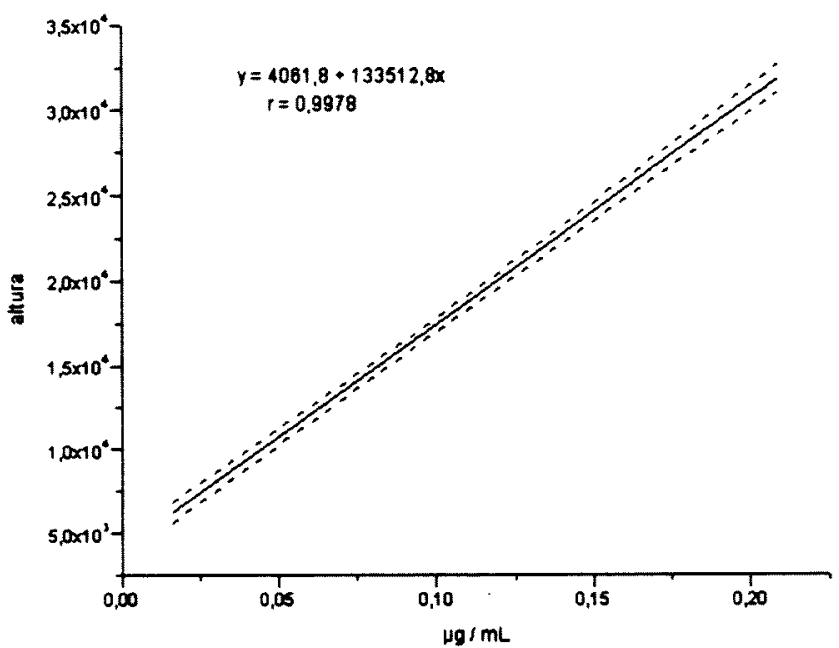

Figura 19 - Representação gráfica da curva de calibração obtida para a faixa de concentração de 10 a $200 \mathrm{ng} / \mathrm{mL}$ de ETU. 
- Parâmetros de confiança do método

Os parâmetros de confiança dos métodos validados (limites de detecçăo-LD e de quantificação-LQ, precisão e recuperação) estăo indicados nas Tabelas 24 e 25.

Tabela 24 - Parâmetros de confiança do método multi-resíduo proposto para a determinação de inseticidas organoclorados em tomate.

\begin{tabular}{|c|c|c|c|c|c|}
\hline padrão & $\begin{array}{l}\text { ED } \\
\text { ppb }\end{array}$ & $\begin{array}{l}\text { LQ } \\
\text { ppo }\end{array}$ & $\begin{array}{l}\text { Intervalo dinamico } \\
(\mu \mathrm{g} / \mathrm{m} L))^{-}\end{array}$ & $\begin{array}{c}\text { Precisao } \\
(\%)\end{array}$ & $\begin{array}{c}\text { recuperacao } \\
(\%)\end{array}$ \\
\hline$\alpha-\mathrm{HCH}$ & 1,0 & 4,1 & $\begin{array}{l}1,2-25,0 \\
(r=0,99)\end{array}$ & 12,6 & 80,9 \\
\hline HCB & 0,5 & 2,1 & $\begin{array}{l}0,6-12,5 \\
(r=0,98)\end{array}$ & 19,7 & 79,2 \\
\hline$\beta-\mathrm{HCB}$ & 1,0 & 8,4 & $\begin{array}{l}1,2-25,0 \\
(r=0,98)\end{array}$ & 13,8 & 84,0 \\
\hline$\gamma-\mathrm{HCH}$ & 1,0 & 4,2 & $\begin{array}{l}1,2-25,0 \\
(r=0,98)\end{array}$ & 11,4 & 83,7 \\
\hline$\delta-\mathrm{HCH}$ & 1,1 & 4,2 & $\begin{array}{l}1,3-25,0 \\
(r=0,99)\end{array}$ & 14,1 & 86,3 \\
\hline heptacloro & 1,0 & 4,2 & $\begin{array}{l}1,2-25,0 \\
(r=0,98)\end{array}$ & 9,9 & 86,1 \\
\hline aldrin & 1,0 & 4,1 & $\begin{array}{l}1,2-25,0 \\
(r=0,99)\end{array}$ & 16,8 & 78,4 \\
\hline $\begin{array}{l}\text { heptacloro } \\
\text { epóxido }\end{array}$ & 1,0 & 8,3 & $\begin{array}{l}1,2-25,0 \\
(r=0,98)\end{array}$ & 11,5 & 85,8 \\
\hline$\gamma$ - clordano & 1,0 & 4,2 & $\begin{array}{l}1,2-50,0 \\
(r=0,98)\end{array}$ & 14,6 & 83,5 \\
\hline$\alpha$ - clordano & 1,1 & 4,3 & $\begin{array}{l}1,2-50,0 \\
(r=0,98)\end{array}$ & 16,2 & 82,8 \\
\hline$p p^{\prime}-D D E$ & 1,0 & 4,1 & $\begin{array}{l}1,2-60,0 \\
(r=0,98)\end{array}$ & 14,9 & 82,0 \\
\hline
\end{tabular}


Continuação da Tabela 24.

\begin{tabular}{|c|c|c|c|c|c|}
\hline dieldrin & 1,0 & 8,4 & $\begin{array}{l}1,2-20,0 \\
(r=0,98)\end{array}$ & 7,0 & 78,1 \\
\hline$O p^{\prime}-\mathrm{DDD}$ & 1,0 & 8,5 & $\begin{array}{l}1,2-50,0 \\
(r=0,98)\end{array}$ & 9,1 & 81,6 \\
\hline endrin & 1,1 & 9,5 & $\begin{array}{l}1,4-12,5 \\
(r=0,98)\end{array}$ & 6,3 & 84,4 \\
\hline$p p^{\prime}-D D D$ & 2,5 & 10,5 & $\begin{array}{l}3,1-50,0 \\
(r=0,98)\end{array}$ & 15,5 & 80,5 \\
\hline op' - DDT & 2,5 & 10,3 & $\begin{array}{l}3,0-50,0 \\
(r=0,98)\end{array}$ & 13,9 & 76,8 \\
\hline pp' - DDT & 2,5 & 10,4 & $\begin{array}{l}3,1-50,0 \\
(r=0,98)\end{array}$ & 13,1 & 76,9 \\
\hline Mirex & 2,5 & 21,2 & $\begin{array}{l}3,1-50,0 \\
(r=0,98)\end{array}$ & 13,1 & 76,9 \\
\hline$\alpha$ - endosulfan & 1,9 & 4,0 & $\begin{array}{l}2,5-14,9 \\
(r=0,99)\end{array}$ & 3,5 & 86,3 \\
\hline$\beta$ - endosulfan & 2,1 & 4,2 & $\begin{array}{l}2,6-15,6 \\
(r=0,99)\end{array}$ & 8,2 & 81,4 \\
\hline $\begin{array}{l}\text { endosulfan } \\
\text { sulfato }\end{array}$ & 4,7 & 6,1 & $\begin{array}{l}5,1-25,3 \\
(r=0,99)\end{array}$ & 7,8 & 104,3 \\
\hline
\end{tabular}


Tabela 25- Parâmetros de confiança dos métodos multi-resíduos e específicos propostos para a determinação de inseticidas organofosforados e etilenotiuréia (ETU) em tomate.

\begin{tabular}{|c|c|c|c|c|c|}
\hline \multirow[b]{3}{*}{ padrão } & \multicolumn{5}{|c|}{ parâmetros } \\
\hline & & LQ & Intervalo dinâmico & precisāo & recuperação \\
\hline & LD & ppm & $(\mu \mathrm{g} / \mathrm{mL})$ & $(\mathrm{CV} \%)$ & $(\%)$ \\
\hline diclorvós & - & 0,02 & $\begin{array}{c}0,012-0,046 \\
(r=0,99)\end{array}$ & 13,3 & 96,0 \\
\hline fosdrin & - & 0,03 & $\begin{array}{c}0,022-0,089 \\
(r=0,99)\end{array}$ & 21,0 & 85,1 \\
\hline diazinon & - & 0,03 & $\begin{array}{c}0,021-0,082 \\
(r=0,99)\end{array}$ & 10,3 & 91,0 \\
\hline fenclorvós & - & 0,09 & $\begin{array}{c}0,052-0,208 \\
(r=0,99)\end{array}$ & 9,0 & 96,6 \\
\hline pirimifós metil & - & 0,08 & $\begin{array}{c}0,051-0,202 \\
(r=0,99)\end{array}$ & 6,7 & 97,4 \\
\hline paration metil & - & 0,08 & $\begin{array}{c}0,051-0,202 \\
(r=0,99)\end{array}$ & 14,1 & 88,0 \\
\hline malation & - & 0,09 & $\begin{array}{c}0,056-0,222 \\
(r=0,99)\end{array}$ & 14,0 & 92,6 \\
\hline fenitrotion & - & 0,08 & $\begin{array}{c}0,051-0,204 \\
(r=0,99)\end{array}$ & 12,1 & 90,7 \\
\hline paration etil & - & 0,05 & $\begin{array}{c}0,030-0,121 \\
(r=0,99)\end{array}$ & 10,3 & 98,9 \\
\hline metamidofós & 0,04 & 0,05 & $\begin{array}{l}0,16-1,6 \\
(r=0,99)\end{array}$ & 15,0 & 80,5 \\
\hline ETU & 0,01 & 0,025 & $\begin{array}{c}0,025-0,2 \\
(r=0,99)\end{array}$ & 20,1 & 77,0 \\
\hline
\end{tabular}




\subsection{ANALISE dE RESIDUOS DE PRAgUICIDAS NAS AMOSTRAS DE} TOMATE SELECIONADAS PARA ESTUDO

As Tabelas 26 e 27 mostram os resultados obtidos das análises de resíduos de praguicidas para as 27 amostras sorteadas no Projeto Senador Nilo Coelho.

Tabela 26 - Resultados da análise de resíduos de inseticidas organoclorados e organofosforados das 27 amostras de tomate para indústria sorteadas no Projeto Senador Nilo Coelho, segundo a época de plantio e empresa contratada.

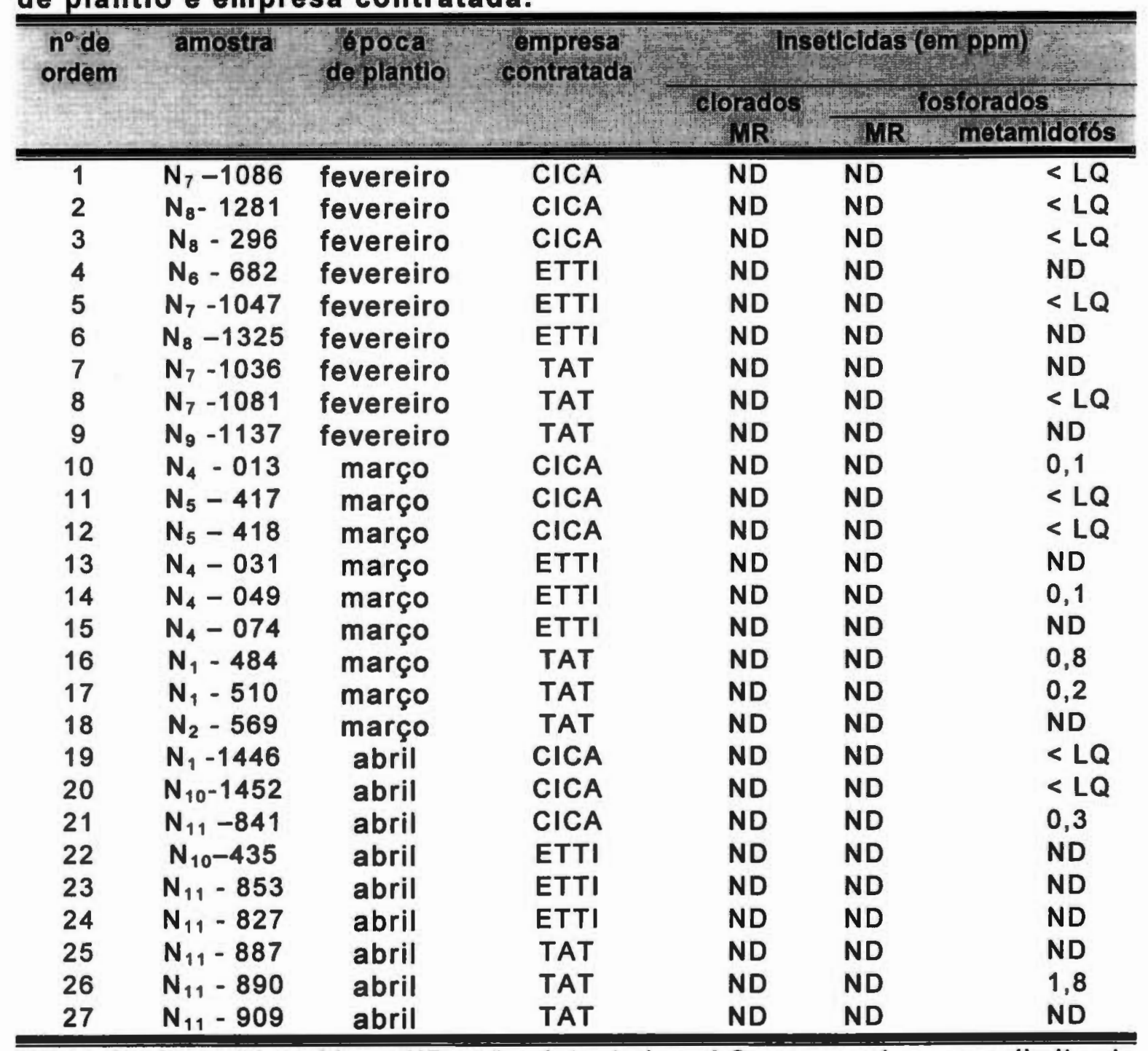

MR: método multi-resíduos ND: não detectado; <LQ: menor do que o limite de quantificaçăo do método. 
Tabela 27- Resultados da análise de resíduos de ETU das 27 amostras de tomate para indústria sorteadas no Projeto Senador Nilo Coelho, segundo a época de plantio e empresa contratada.

\begin{tabular}{|c|c|c|c|c|}
\hline $\begin{array}{l}n^{\circ} \text { de } \\
\text { ordem }\end{array}$ & amostra & $\begin{array}{c}\text { época } \\
\text { de plantio }\end{array}$ & $\begin{array}{l}\text { empresa } \\
\text { contratada }\end{array}$ & ETU (em ppb) \\
\hline $\begin{array}{c}1 \\
2 \\
3 \\
4 \\
5 \\
6 \\
7 \\
8 \\
9 \\
10 \\
11 \\
12 \\
13 \\
14 \\
15 \\
16 \\
17 \\
18 \\
19 \\
20 \\
21 \\
22 \\
23 \\
24 \\
25 \\
26 \\
27\end{array}$ & $\begin{array}{l}N_{7}-1086 \\
N_{8}-1281 \\
N_{8}-1296 \\
N_{6}-682 \\
N_{7}-1047 \\
N_{8}-1325 \\
N_{7}-1036 \\
N_{7}-1081 \\
N_{9}-1137 \\
N_{4}-013 \\
N_{5}-417 \\
N_{5}-418 \\
N_{4}-031 \\
N_{4}-049 \\
N_{4}-074 \\
N_{1}-484 \\
N_{1}-510 \\
N_{2}-569 \\
N_{10}-1446 \\
N_{10}-1452 \\
N_{11}-841 \\
N_{10}-435 \\
N_{11}-853 \\
N_{11}-827 \\
N_{11}-887 \\
N_{11}-890 \\
N_{11}-909\end{array}$ & $\begin{array}{c}\text { fevereiro } \\
\text { fevereiro } \\
\text { fevereiro } \\
\text { fevereiro } \\
\text { fevereiro } \\
\text { fevereiro } \\
\text { fevereiro } \\
\text { fevereiro } \\
\text { fevereiro } \\
\text { março } \\
\text { março } \\
\text { março } \\
\text { março } \\
\text { março } \\
\text { março } \\
\text { março } \\
\text { março } \\
\text { março } \\
\text { abril } \\
\text { abril } \\
\text { abril } \\
\text { abril } \\
\text { abril } \\
\text { abril } \\
\text { abril } \\
\text { abril } \\
\text { abril }\end{array}$ & $\begin{array}{l}\text { CICA } \\
\text { CICA } \\
\text { CICA } \\
\text { ETTI } \\
\text { ETTI } \\
\text { ETTI } \\
\text { TAT } \\
\text { TAT } \\
\text { TAT } \\
\text { CICA } \\
\text { CICA } \\
\text { CICA } \\
\text { ETTI } \\
\text { ETTI } \\
\text { ETTI } \\
\text { TAT } \\
\text { TAT } \\
\text { TAT } \\
\text { CICA } \\
\text { CICA } \\
\text { CICA } \\
\text { ETTI } \\
\text { ETTI } \\
\text { ETTI } \\
\text { TAT } \\
\text { TAT } \\
\text { TAT }\end{array}$ & $\begin{array}{l}\text { ND } \\
<\text { LQ } \\
N D \\
N D \\
N D \\
N D \\
N D \\
<L Q \\
N D \\
N D \\
N D \\
34,2 \\
<L Q \\
N D \\
N D \\
27,7 \\
<L Q \\
<L Q \\
<L Q \\
<L Q \\
<L Q \\
<L Q \\
N D \\
31,3 \\
<L Q \\
<L Q \\
<L Q\end{array}$ \\
\hline
\end{tabular}

ND: nåo detectado

$<L Q$ : menor do que o limite de quantificaçăo do método

As Tabelas 28 e 29 mostram os resultados obtidos das análises de resíduos de praguicidas para as 32 amostras selecionadas no Município de Camocim de São Félix. 
Tabela 28 - Resultados da análise de resíduos de inseticidas organoclorados e organofosforados das 32 amostras de tomate de mesa selecionadas no Município de Camocim de São Félix.

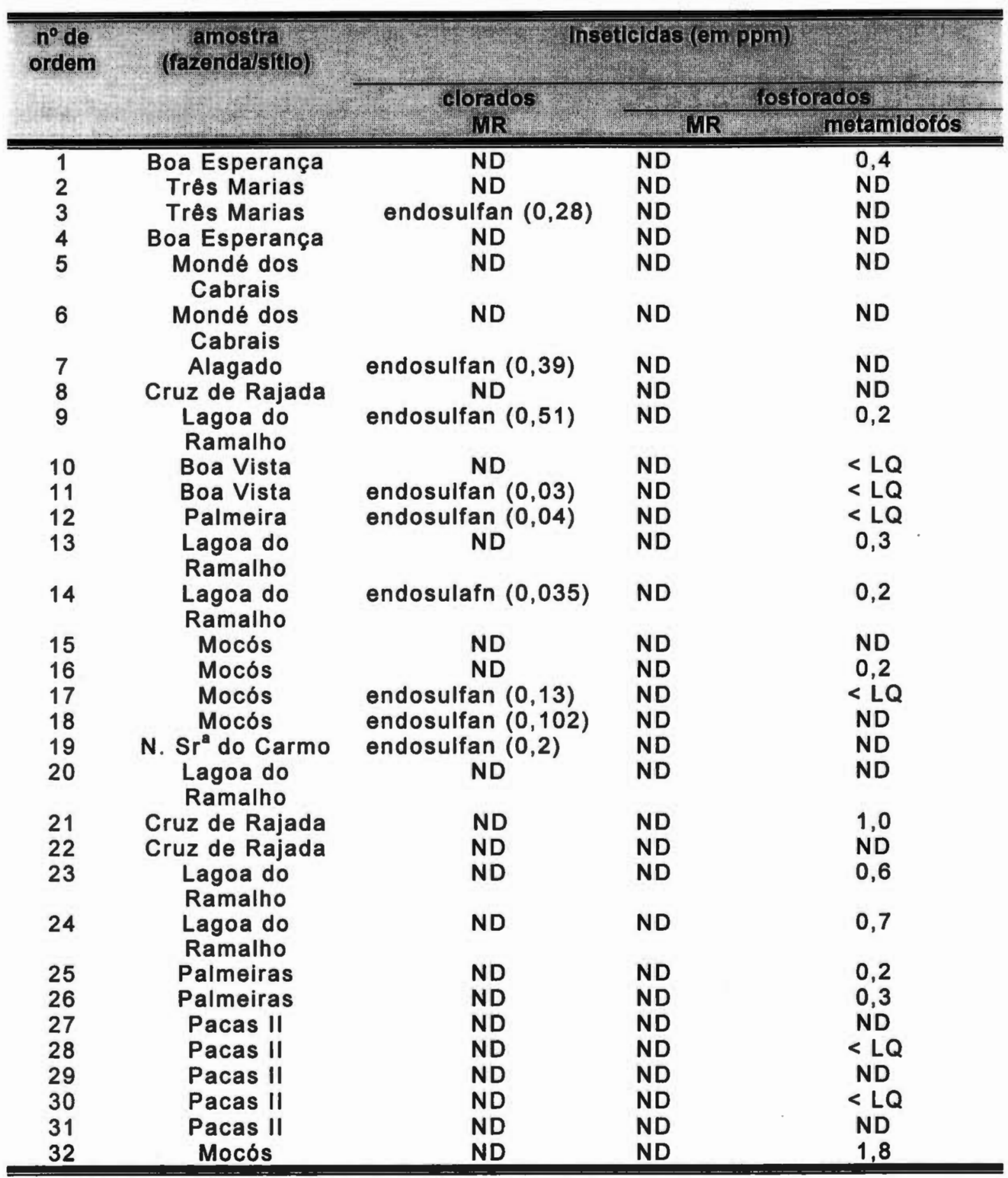

MR: método multi-resíduos

ND: não detectado

< LQ: menor do que o limite de quantificaçăo do método 
Tabela 29 - Resultados da análise de resíduos de ETU das 32 amostras de tomate de mesa selecionadas no Município de Camocim de São Félix.

\begin{tabular}{|c|c|c|}
\hline $\begin{array}{l}n^{\circ} \text { de } \\
\text { ordem }\end{array}$ & amostra (fazenda/sitio) & ETU (em ppb) \\
\hline $\begin{array}{c}1 \\
2 \\
3 \\
4 \\
5 \\
6 \\
7 \\
8 \\
9 \\
10 \\
11 \\
12 \\
13 \\
14 \\
15 \\
16 \\
17 \\
18 \\
19 \\
20 \\
21 \\
22 \\
23 \\
24 \\
25 \\
26 \\
27 \\
28 \\
29 \\
30 \\
31 \\
32\end{array}$ & $\begin{array}{c}\text { Boa Esperança } \\
\text { Trés Marias } \\
\text { Trés Marias } \\
\text { Boa Esperança } \\
\text { Mondé dos Cabrais } \\
\text { Mondé dos Cabrais } \\
\text { Alagado } \\
\text { Cruz de Rajada } \\
\text { Lagoa do Ramalho } \\
\text { Boa Vista } \\
\text { Boa Vista } \\
\text { Palmeira } \\
\text { Lagoa do Ramalho } \\
\text { Lagoa do Ramalho } \\
\text { Mocós } \\
\text { Mocós } \\
\text { Mocós } \\
\text { Mocós } \\
\text { Nossa Sra do Carmo } \\
\text { Lagoa do Ramalho } \\
\text { Cruz de Rajada } \\
\text { Cruz de Rajada } \\
\text { Lagoa do Ramalho } \\
\text { Lagoa do Ramalho } \\
\text { Palmeiras } \\
\text { Palmeiras } \\
\text { Pacas II } \\
\text { Pacas II } \\
\text { Pacas II } \\
\text { Pacas II } \\
\text { Pacas II } \\
\text { Mocós }\end{array}$ & $\begin{array}{l}<L Q \\
<L Q \\
<L Q \\
<L Q \\
N D \\
<L Q \\
N D \\
N D \\
<L Q \\
<L Q \\
<L Q \\
<L Q \\
<L Q \\
<L Q \\
N D \\
<L Q \\
<L Q \\
<L Q \\
<L Q \\
<L Q \\
<L Q \\
\quad N D \\
<L Q \\
<L Q \\
<L Q \\
<L Q \\
<L Q \\
N D \\
N D \\
<L Q \\
<L Q \\
<L, 6 \\
26,6\end{array}$ \\
\hline
\end{tabular}

ND: năo detectado;

< LQ: menor do que o limite de quantificaçăo do método. 

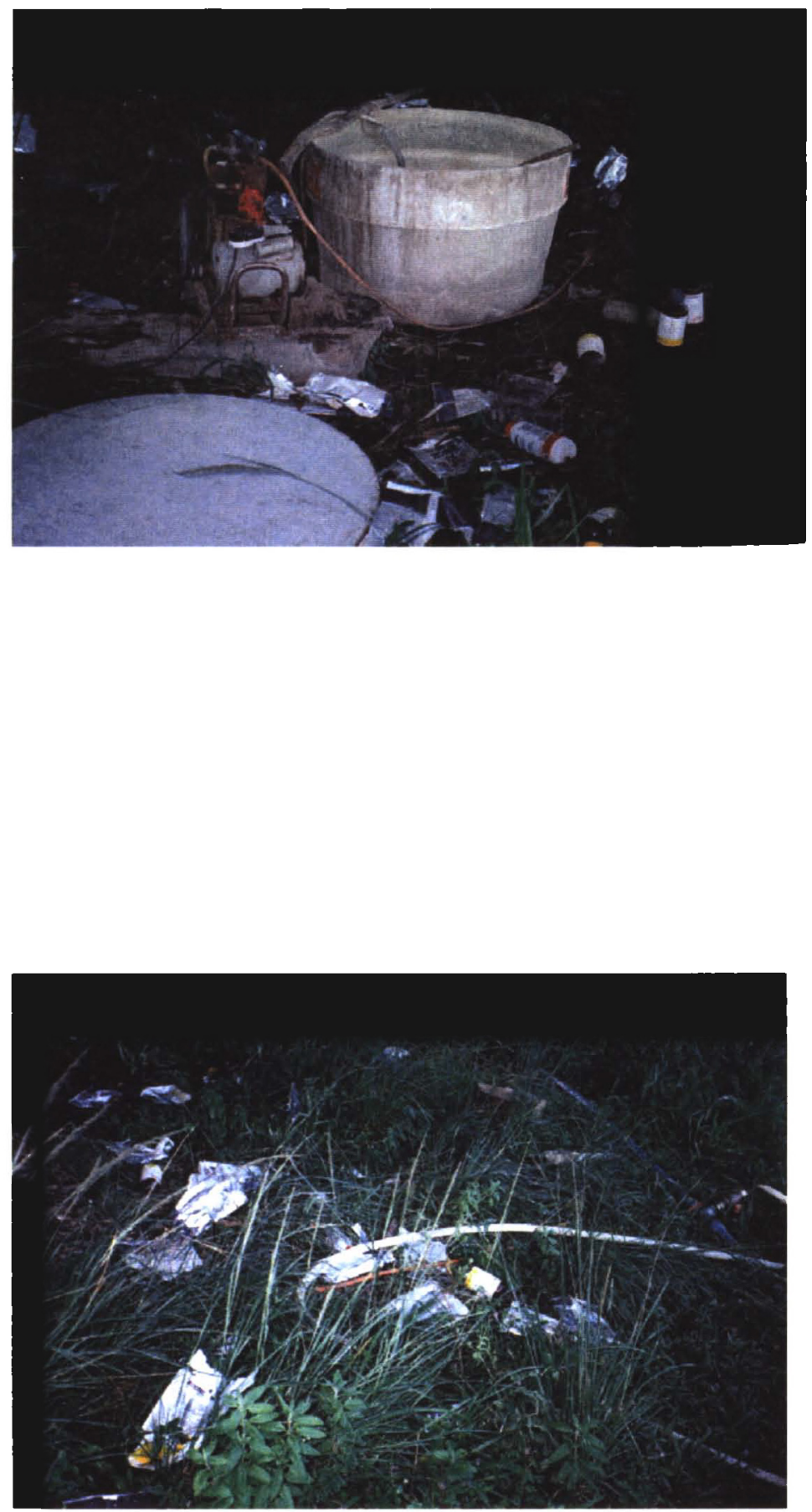

Figura 20a e 20b - Descarte de embalagens vazias de praguicidas após o uso em culturas de tomate do Municipio de Camocim de São Félix. 


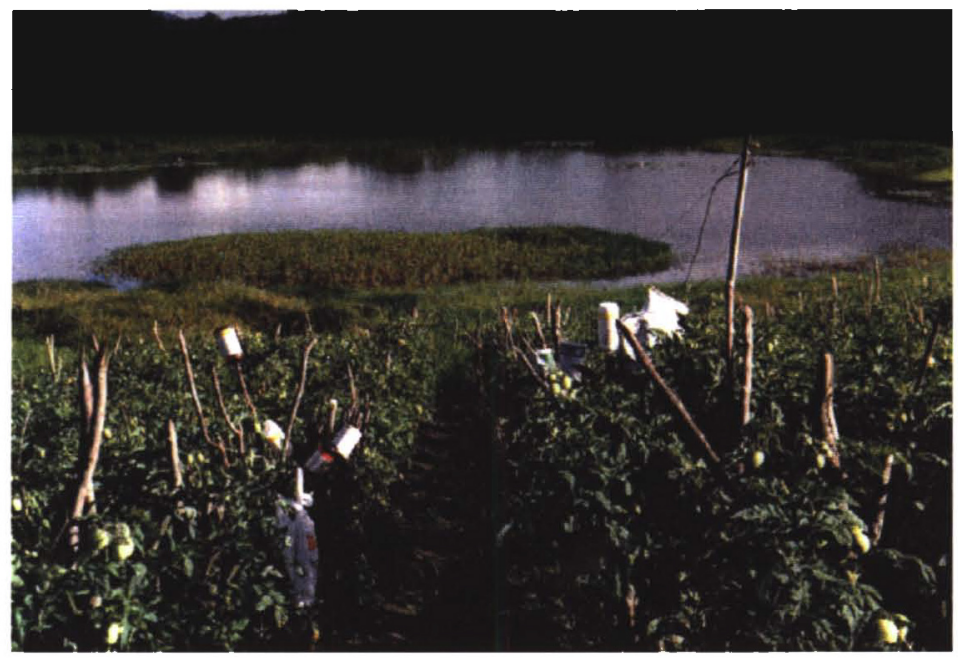

Figura 21 - Descarte de embalagens vazias de praguicidas após o uso em culturas de tomate do Município de Camocim de São Félix, próximo ao reservatório de água.

Em geral, na exposição a produtos químicos em um ambiente fabril, há um risco maior para os trabalhadores diretamente envolvidos com o processo produtivo, $e$ isso foi constatado no Estado de Pernambuco por Araújo e col. (1993). No entanto, na produção agrícola, o uso inadequado de praguicidas provoca impactos para além do aspecto ocupacional, afetando o meio ambiente, os consumidores e os familiares que vivenciam o processo produtivo. Foi possível observar esse fato em Camocim de São Félix, onde o tomate é ingerido, no campo, como fonte de alimento por crianças filhas dos trabalhadores (Figura 22). Essas evidências mostraram, também, que as ações corretivas devem ser feitas no ambiente como um todo e no processo produtivo, não se restringindo aos aplicadores de praguicidas. 


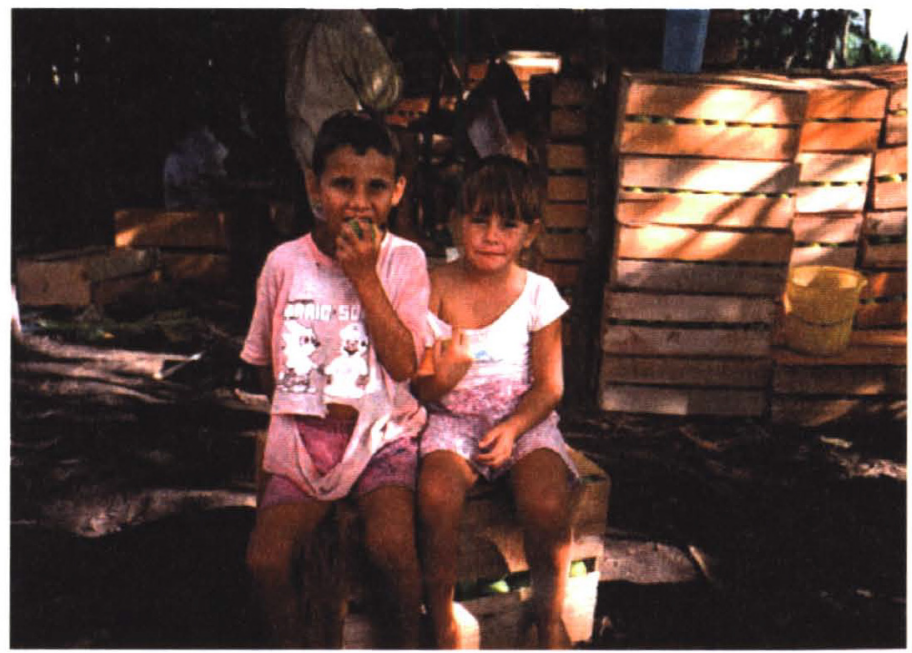

Figura 22 - Filhos de produtores de tomate do Município de Camocim de São Félix ingerindo o fruto retirado diretamente do tomateiro.

Os métodos analíticos utilizados para este trabalho apresentaram resultados satisfatórios, conforme mostram os dados da validação, com limites de quantificação, quando pertinentes, coerentes com os limites máximos aceitos pela legislação brasileira. A variação do coeficiente de correlação $(r)$ foi de 0,98 a 0,99 , porém o coeficiente de determinação $\left(r^{2}\right)$ também apresentou boa relação, com variação entre 0,96 a 0,98 .

Para a análise de um grande número de amostras nas quais, historicamente, o tratamento com praguicidas é desconhecido, são indicados métodos analíticos capazes de determinar, simultaneamente, diversos resíduos de praguicidas. Esses métodos, chamados de multiresíduos, podem analisar até cerca de 300 princípios ativos ao mesmo tempo, abrangendo diferentes classes de praguicidas. Os métodos seletivos para resíduos, por sua vez, são empregados para a determinação 
6 - DISCUSSÃO 
A análise efetuada com os dados dos órgãos oficiais envolvidos com a agricultura no Estado de Pernambuco mostra claramente que não há uma correlação entre os tipos de culturas e os praguicidas mais utilizados conforme as caracteristicas agropecuárias de cada mesorregião. Por exemplo, na Zona da Mata Pernambucana, tipicamente reduto do cultivo da cana-de-açúcar, houve apenas duas citações para dois tipos de herbicidas, o paraquat e o 2,4-D. Apesar de não ser possivel, por esses dados, avaliar a quantidade de princípios ativos/hectare utilizada em cada região, podese dizer que a diversidade de praguicidas em uso em todo o Estado é elevada $(n=127)$

Esses dados, acrescidos aos fornecidos pela Secretaria Municipal de Petrolina e pela EMBRAPA/CPATSA, também são responsáveis por outras preocupações. A utilização de Polytrin (8) (profenofós + cypermetrina), por exemplo, citado em todas as mesorregiōes do Estado, sobretudo no Agreste e no perimetro irrigado Projeto Senador Nilo Coelho, onde o seu uso não se justifica, pois o mesmo é prescrito apenas para as culturas de algodão e café.

Foram citados 35 produtos sem registro e de composição desconhecida, além de inseticidas organoclorados, alguns de empregos agrossanitário e domissanitário não autorizados, como é o caso do aldrin. Os demais produtos clorados citados foram endosulfan, dicofol, mirex e dieldrin, todos não indicados para a cultura do tomate.

Os dados fornecidos pela Secretaria de Agricultura do Municipio de Petrolina indicam que, do total de principios ativos empregados/hectare no perimetro irrigado, os produtos de origem biológica representam $68,9 \%$ e os de origem quimica, $31,1 \%$. Na classe dos fungicidas, responsável por 
$29,5 \%$ do total, a citação mais freqüente cabe aos fungicidas da classe dos etilenobisditiocarbamatos $(57,4 \%)$, seguidos pelos compostos cúpricos $(20,4 \%)$. Os compostos contendo enxofre responderam por apenas $7,3 \%$ do total de fungicidas, ficando $14,8 \%$ destinados ao uso de outros produtos de ação fúngica.

Os dados obtidos pela investigação junto aos produtores de tomate das áreas estudadas revelaram que no perimetro irrigado há, de fato, maior consumo de produtos de origem biológica, citados por $96 \%$ dos entrevistados. Provavelmente, esse fato representa um conhecimento e uma orientação técnica maiores do que os observados entre os produtores do Municipio de Camocim de Sảo Félix, onde apenas $31 \%$ fizeram uso dos produtos biológicos.

Apenas quatro produtores do Projeto Senador Nilo Coelho limitaramse aos praguicidas cedidos pelas agroindústrias, no entanto, não foi observado o uso de produto proibido para a cultura de tomate. Esse é mais um dado que indica obediência à orientaçăo técnica recebida da empresa, dos funcionários do Distrito de Irrigação e dos técnicos da EMBRAPA.

As informações obtidas em Camocim de São Félix mostraram o uso de quatro inseticidas não permitidos para o tomateiro, dentre eles três organoclorados e um com registro cancelado, além disso foram citados mais três de origem desconhecida. Os tipos e quantidades de praguicidas utilizados variavam consideravelmente entre os produtores, o que indica falta de orientação técnica ou decisão individual, que se revela, também, no fato de os praguicidas serem aplicados, via de regra, preventivamente. Esse é um grave problema fitossanitário, em particular, pela possibilidade 
de aumentar a resistência de pragas e requerer um crescente uso de novos produtos e misturas, o que eleva o custo e as perdas da produção.

Nas duas regiōes de estudo, pôde-se constatar um grande desconhecimento por parte dos produtores e aplicadores de praguicidas no que se refere aos efeitos tóxicos para a saúde e o meio ambiente associados ao uso indevido de praguicidas. As queixas dos agricultores envolvidos na cultura do tomate são, na sua maioria, compativeis com a sintomatologia esperada das intoxicações por esses produtos. As queixas mais freqüentes foram dor de cabeça, náusea, tontura, problemas de pele, alteraçōes de sono e formigamento nos membros superiores. Como se pôde constatar, em Camocim de São Félix, não há um sistema de saúde voltado para o atendimento da população exposta aos praguicidas, o que implica, também, a falta de informação para as medidas de prevenção.

O descarte das embalagens dos praguicidas é um grave problema ambiental na lavoura de tomate de Camocim de São Félix (Figuras 20 a e 20b). A prática, entre alguns produtores e agricultores, de deixar as embalagens vazias ou restos de produtos espalhados pelo campo promove, certamente, através das águas de chuva e de irrigação, o arraste de residuos pelo solo até atingirem reservatórios e cursos de água e provocarem a contaminação ambiental generalizada (Figura 21 ). 
de praguicidas cuja determinação não é possivel ou satisfatória por um método multi-residuos (NFA, 1994). A utilização de métodos seletivos eleva sobremaneira o custo e o tempo envolvidos na análise de residuos, apesar de essas técnicas apresentarem, usualmente, limite de quantificação mais baixo que o obtido por métodos multi-residuos. Assim, na utilização destes últimos, é fundamental que o limite de quantificação obtido seja inferior ao limite tolerável, quando existente, para cada praguicida estudado (FDA, 1993).

O método multi-residuos utilizado foi bastante satisfatório por possibilitar a quantificação nas faixas de concentração de interesse e, sobretudo, por ser rápido e relativamente econômico. No entanto, ele só foi empregado para a análise de 30 principios ativos, sendo 21 inseticidas organoclorados e 9 organofosforados, devido à capacidade laboratorial existente na ocasiăo.

A inclusão de dois métodos especificos para a análise do inseticida organofosforado metamidofós e de fungicidas da classe dos etilenobisditiocarbamatos, através de um produto de degradação (ETU), tornou o trabalho consideravelmente mais oneroso, muito embora a opção se tenha justificado, por serem os compostos de grande citação no controle de pragas do tomateiro e por não existirem referências analiticas das regiōes estudadas, anteriores a este trabalho. O metamidofós (Hamidop (8), Stron (8), Tamaron (8) foi o mais citado $(n=33$ ) no perímetro irrigado Projeto Senador Nilo Coelho; já os fungicidas da classe dos etilenobisditiocarbamatos (Dithane (8), Manzate (8, Ridomil (8) foram os produtos de maior uso na cultura do tomate de mesa do Município de Camocim de São Félix $(n=28)$. 
Na análise da ETU por cromatografia a liquido (HPLC) e detecção por absorção a $240 \mathrm{~nm}$, a propilenotiuréia (PTU) foi testada para uso como padrão interno da ETU. A PTU é o princípio ativo do fungicida ditiocarbamato Propineb (8, de uso não registrado no Brasil e com estrutura química muito semelhante à da ETU, razão pela qual foi escolhida como padrão interno na primeira validação do método proposto. Porém, durante a fase final do trabalho, quando as últimas amostras de tomate de mesa provenientes de Camocim de São Félix foram analisadas, duas delas, $n^{\circ} 30$ e $n^{\circ} 32$, deram resultado positivo para PTU, e seus picos cromatográficos indicavam a presença de quantidades elevadas. Nesse ponto, até mesmo para fins de registro do laboratório, foi elaborada uma curva de calibração para a PTU, com o objetivo de quantificar os resíduos encontrados, obtendo-se 41,3 ppb e 203,1 ppb para as amostras de números 30 e 32 , respectivamente.

Uma preocupaçăo referente ao método proposto para a análise de etilenotiuréia (ETU), citada por Moza e Hustert (1989), foi a verificação de uma possivel co-eluiçăo da etilenouréia (EU), que é outro produto de degradação dos EBDCs; nesse sentido, foi realizada uma corrida cromatográfica de soluçōes contendo os dois padrōes e pôde-se observar que, além de ocorrer a separação dos picos referentes à ETU e à EU, a resposta do detector utilizado para a EU é muito pequena em relação à da ETU, ou seja, $0,5 \mathrm{ng}$ de ETU corresponderam a cerca de $20 \mu \mathrm{g}$ de EU.

Para a extração da ETU, foi inicialmente testada e validada a técnica proposta por Diserens (1991), cujos resultados preliminares obtidos no laboratório foram divulgados em encontro cientifico (Araújo e Gorni, 1995). Porém, devido ao tempo envolvido nas etapas de extração e 
de purificação dos extratos, a técnica publicada por Bolzoni e col. (1993), após algumas modificações, foi escolhida para ser aplicada neste trabalho, também por permitir a análise de um número maior de amostras/dia e consumir uma menor quantidade de solventes. Essa decisão implicou assumir-se uma menor recuperação da ETU em relaçăo à observada na técnica anterior.

A resposta do detector de absorção em $240 \mathrm{~nm}$ apresentou limite de quantificação (LQ) para a solução padrão de ETU correspondente a 0,2 ng / $20 \mu \mathrm{L}$. Porém, para amostras de adicionados de ETU em tomate, O LQ foi obtido com 2,5 ng / $20 \mu \mathrm{L}$, o que representa uma concentração de 25 ppb, valor este superior àqueles citados por alguns autores (Massey e McWeeny, 1982; Greve e Herbold, 1983; Kobayashi, 1992) e, ao mesmo tempo, inferior ao obtido por Lehotay e col. (1992). Niveis de LQ mais baixos poderiam ser estabelecidos com a aplicação de um detector mais seletivo, como o eletroquímico (Doerge e Yee, 1991; Bolzoni e col., 1993; Maruyama, 1994). Neste trabalho, devido a problemas técnicos no detector eletroquímico, o que limitou o tempo necessário para a validação do método quantitativo, ele foi empregado apenas como técnica de confirmação dos picos cromatográficos da ETU, já identificados e quantificados em detector de absorção na região do ultravioleta.

Considerando-se os praguicidas utilizados nas safras de tomate estudadas, industrial e de mesa, segundo dados obtidos pelos questionários, os métodos aplicados cobriram cerca de $20 \%$ de todos os produtos citados. Avaliando-se os praguicidas nảo analisados neste estudo e citados pelos produtores sorteados do perimetro irrigado, a inclusão do inseticida organofosforado Orthene (2) (acefato), citado por 21 dos 26 
produtores $(80,7 \%)$, e do inseticida piretróide Karate (labdacialotrina), citado em $73 \%$ dos casos, abrangeria todos os produtos mais citados na cultura de tomate industrial. Para a cultura de tomate de mesa, por sua vez, a análise de inseticidas piretróides, como Karate (8) (labdacialotrina), Ambush (8) e Talcord (8) (permetrina) e Decis (8) (deltametrina), tornaria 0 trabalho mais completo, visto que os piretróides foram os mais utilizados no Agreste, segundo informações dos próprios produtores. Para os dois casos, do inseticida organofosforado Orthene (8) e dos piretróides relacionados acima, é possível a utilizaçäo de métodos multi-residuos, obtendo-se resultados considerados bastante satisfatórios (NFA, 1994).

Porém, devido a algumas irregularidades observadas na cultura do tomate de mesa praticada no municipio de Camocim de São Félix, como o uso de produtos não permitidos, por exemplo: Kelthane (8) (dicofol) e Curacron (8) (profenofós), provavelmente a inclusāo desses produtos em estudos futuros forneça dados para uma avaliação ainda mais abrangente da prática agrícola adotada na região e dos riscos envolvidos na aplicação de praguicidas.

Com relação aos inseticidas organoclorados, ficou evidente, tanto pelos levantamentos obtidos pela Secretaria Estadual de Agricultura e EMATER/PE, como pelas análises residuais realizadas, que eles ainda são utilizados no Estado e, portanto, devem ser incluidos em todos os estudos analiticos realizados.

Os resultados analiticos obtidos pelo método multi-residuos para os inseticidas organofosforados estudados foram negativos para as duas regiōes produtoras de tomate. No tomate de mesa, foi detectada a presença de diazinon, porém em quantidade abaixo do limite de tolerância 
estabelecido pela legislação brasileira, que é de $0,5 \mathrm{ppm}$. Na análise de duas amostras provenientes de Camocim de São Félix, os cromatogramas registraram um pico com tempo de retenção em 10,2 min, porém, pelo fato de este não coincidir com os tempos de retenção dos princípios ativos analisados neste trabalho, não foi possivel a sua identificação.

Por outro lado, valores acima do permitido de inseticida organofosforado metamidofós $(0,3 \mathrm{ppm})$, identificado por método especifico, estavam presentes em $11,1 \%$ e $25 \%$ das amostras de tomate do Projeto Senador Nilo Coelho e de Camocim de São Félix, respectivamente. As concentrações encontradas variaram entre 0,3 ppm a cerca de 2,0 ppm para as duas regiōes.

As duas concentrações de metamidofós mais elevadas encontradas no tomate industrial, 0,8 e $1,8 \mathrm{ppm}$, foram detectadas em plantações cujo fornecimento do pacote de praguicidas foi realizado pela mesma empresa, a TAT; porém, o produto técnico fornecido, Tamaron @, é de uso permitido nessa cultura, o que sugere a utilização indevida pelo produtor. Quanto à segunda variável considerada, época de plantio, observou-se que duas amostras de tomate positivas para metamidofós, amostras $n^{\text {os }} 21$ e 26 , tiveram o seu plantio em época de seca, quando, segundo os técnicos agrícolas da região, há maior possibilidade da ocorrência de pragas; a terceira amostra de tomate positiva para metamidofós, $n^{0} 16$, iniciou 0 plantio em época considerada intermediária entre chuva e seca.

Comparando-se os valores encontrados neste trabalho com os resultados de um monitoramento de praguicidas realizado no estado do Paraná durante cinco anos (Zandoná e Zappia, 1993), observou-se que os primeiros são elevados. No Paraná, 26 amostras de tomate foram 
analisadas, das quais $38,5 \%$ apresentaram algum tipo de residuo. Os principios ativos encontrados foram: BHC, metamidofós, metaxil e aldicarb, em $100,40,80$ e $43 \%$ das amostras investigadas, respectivamente. Porém, dos resultados encontrados para metamidofós, apenas um, com 0,35 ppm representou violação da legislação vigente.

$\mathrm{Na}$ análise da ETU, três amostras de tomate industrial $(11,1 \%)$ e apenas uma de tomate de mesa $(3,1 \%)$ apresentaram resultados acima do limite de quantificação do método proposto. No entanto, a ETU foi detectada em 25 das 32 amostras de tomate de mesa $(78,1 \%)$ e em 15 das 27 de tomate industrial $(55,5 \%)$.

A legislação brasileira estabelece niveis de tolerância para os fungicidas da classe do EBDCs bastante discutiveis; para o maneb, a tolerância em tomate é de $2 \mathrm{ppb}$, enquanto que, para o mancozeb e zineb a tolerância estabelecida para a mesma cultura está baseada no residuo de dissulfeto de carbono $\left(\mathrm{CS}_{2}\right)$, liberado na hidrólise ácida do fungicida e quantificado por colorimetria.

São raros os trabalhos de monitoramento de residuos de fungicidas da classe dos EBDCs realizados no Brasil, sobretudo os baseados na deteç̧ão da ETU. Em um deles, Dal Piva e col.(1995) encontraram valores acima de 20 ppm em batatas inglesas cultivadas no Rio Grande do Sul, o que é bastante preocupante. O limite máximo de residuos de ETU em água para alguns paises é de 3 ppb (Neil e Williams, 1990); em alimentos, a Alemanha aceita até $50 \mathrm{ppb}$ (Dal Piva, 1995), enquanto que a FAO/WHO estabeleceu valores entre 10 a $100 \mathrm{ppb}$ para 11 tipos de vegetais (Bolzoni, 1993). 
O trabalho realizado por Reis e Caldas (1991) mostra que a presença de ETU em tomate deve ser avaliada de forma criteriosa. Nesse estudo, envolvendo 466 amostras de hortaliças e frutas coletadas na cidade do Rio de Janeiro, residuos de fungicidas ditiocarbamatos foram detectados, nas suas formas inalteradas, em $63 \%$ das amostras. Do total de amostras com residuos de ETU, $24 \%$ encontravam-se com valores acima dos permitidos, e os tomates foram responsáveis por $38,2 \%$ dessas amostras que violaram a legislação em vigor. Os autores chamam a atenção para o fato de a ETU não ter sido analisada e poder estar presente em todas as amostras com resultados positivos para os fungicidas precursores da mesma.

Em termos de residuos de praguicidas no tomate, no entanto, a maior prova de irregularidade foi detectada no tomate de mesa: das 32 amostras de tomate provenientes de Camocim de São Félix, nove, portanto, $28,1 \%$, deram resultado positivo para o inseticida organoclorado endosulfan, e apenas um produtor citou o seu uso (Thiodan (8). Pode ter ocorrido omissão intencional dos demais produtores, visto que se trata de um produto de uso proibido para a cultura de tomate, mas pode ser, também, a dificuldade que têm de ler o rótulo, lembrar ou descrever os produtos empregados.

A contaminação, a baixas concentrações, por organoclorados não significa necessariamente o emprego direto desses produtos. Trabalhos confirmando a sua persistência nos solos por vários anos indicam a possibilidade de que a aplicação dos referidos praguicidas possa ter ocorrido anteriormente à portaria $n^{\circ} 329$ de 02/09/85, do Ministério da Agricultura, com conseqüente contaminação do solo (Oliveira e Toledo, 
1995). Porém, com uma meia vida de aproximadamente 6 meses no solo e a possibilidade de hidrólise na água, o endosulfan não é persistente e cumulativo como outros compostos clorados do grupo dos ciclodienos. (Lemes e col., 1993). Além disso, os niveis de endosulfan encontrados neste trabalho podem ser considerados altos, com valores até $510 \mathrm{ppb}$.

O endosulfan tem sido detectado em amostras de frutas e hortaliças comercializadas em algumas cidades do pais, em diferentes periodos: em amostras coletados na CEASA de Belo Horizonte-MG, a concentração variou de 4 a 220 ppb (Soares, 1986); na cidade de São Paulo-SP, em trabalho de monitoramento realizado pelo Instituto Biológico entre 1983 a 1988, ele foi detectado em 29,3\% das amostras (Guindani e Ungaro, 1988), e em outro monitoramento efetivado pelo mesmo órgão, no ano de 1994 (Gebara e col., 1995), ele foi detectado em frutas comercializadas na CEAGESP; concentrações de 14,40 e 60 ppb foram encontradas em amostras da cidade de Campinas-SP (Oliveira e Toledo, 1995).

Em trabalho de monitoramento de alimentos consumidos no estado de São Paulo, realizado em 1994 pelo Instituto Adolfo Lutz, foram realizadas 4.809 determinaçōes de inseticidas organofosforados e organoclorados em 242 amostras. Apenas uma irregularidade foi observada com relaçảo a 10 ppb de endosulfan, quantificados em uma amostra de tomate, o que levou os autores a concluirem que as normas regulamentadoras governamentais e as boas práticas agrícolas estavam sendo obedecidas e seguidas naquele estado (Barretto e col., 1996).

Segundo Garcia (1996), a detecção de endosulfan no trabalho de monitoramento realizado pelo Instituto Biológico de São Paulo, citado anteriormente (Guindani e Ungaro, 1988), indica fácil acesso dos 
produtores a esse praguicida. Após 1985, apesar de proibido, ele tinha uso emergencial autorizado apenas para algumas culturas que não incluiam o morango e, mesmo nesses casos, mediante receituário agronômico.

No Brasil, o endosulfan está classificado como éster do ácido sulfuroso de um diol cíclico, e o seu uso é permitido nas culturas de cacau e cana-de-açúcar, com tolerância de $10 \mathrm{ppb}$, e de café, cujos grãos podem conter até $40 \mathrm{ppb}$ (ILSI-Brasil, 1995). Esse produto tem seu uso proibido na Bulgária e é severamente controlado na Dinamarca, Hungria, Grécia e Suécia desde 1986 (Dinham, 1993).

O endosulfan é constituido por dois esteroisômeros, alfa e beta. Pelo fato de o produto ser um éster, sua hidrólise é favorecida, o que transforma seus isômeros nos dióis e sulfatos correspondentes. O endosulfan diol e o sulfato de endosulfan, principais produtos de biotransformação do endosulfan, apresentam toxicidades distintas: o primeiro não é tóxico, enquanto que o segundo apresenta uma toxicidade similar à do composto precursor, e, por isso, considera-se residuo de endosulfan a soma dos niveis encontrados dos isômeros alfa e beta e do sulfato de endosulfan (WHO, 1984; Lemes e col., 1993).

O endosulfan está entre os produtos que apresentam maior toxicidade aguda em peixes. E um inseticida organoclorado de amplo espectro. Em peixes, age no SNC, nas brânquias, em glândulas produtoras de hormônios, na concentração de proteínas séricas totais e alterações estruturais nos hepatócitos. Como conseqüência, a intoxicação por endosulfan pode alterar o comportamento, o metabolismo e o sucesso reprodutivo dos peixes. Descaracterização da forma celular e da membrana plasmática, lateralização nuclear, cromatina condensada na 
região central e núcleos picnóticos, grandes vacúolos citoplasmáticos e necrose focal foram as alteraçōes observadas nas células hepáticas de peixes expostos ao endosulfan por diferentes tempos. Os resultados indicaram que o endosulfan é altamente tóxico para a espécie de peixe Brachydanio rerio e que, apesar de sua rápida degradação na água, fica acumulado nos tecidos (Viana e Martins, 1995). Segundo Viana e Martins (1995), algumas alteraçōes histológicas observadas sugerem evolução de neoplasias e indicam a necessidade de estudos da exposição a longo prazo. Em camarāo de água doce, Macrobrachium rosenbergii, foi observado que o endosulfan provoca alterações no comportamento natatório, perda de equilibrio, mudança na coloração natural e aumento da freqüência de muda (Lombardi e col., 1997). Portanto, cuidados especiais devem ser introduzidos no manuseio desse produto em locais próximos a mananciais, rios, lagos ou com declives que facilitem o seu arraste (Lemes e col., 1993).

O endosulfan pode ser absorvido pelo trato gastro-intestinal, por inalação ou por contato com a pele. O maior risco para o homem associado ao endosulfan é a exposição acidental ou ocupacional e, em caso de intoxicação aguda, podem ocorrer manifestações neurológicas, como irritabilidade e convulsōes (Lemes e col., 1993).

Ainda com relaçăo às amostras de tomate provenientes de Camocim de Sảo Félix, é importante registrar a presença de picos não identificados durante a análise dos organoclorados em oito das 32 amostras. Nas condiçōes estabelecidas, dois picos com tempos de retenção em 13,7 e 26 minutos indicavam a presença de algum outro produto cujo principio ativo não estava sendo estudado. Foi realizada uma tentativa de identificação 
utilizando-se os padrōes dos fungicidas clorotalonil, cujo limite de tolerância é $1,0 \mathrm{ppm}$, e vinclozolina, de uso não permitido para o tomateiro, porém os tempos de retenção não corresponderam aos dos produtos suspeitos.

Considerando a atual legislaçăo do pais sobre residuos de praguicidas em alimentos (ILSI-Brasil, 1995), três amostras provenientes do perímetro irrigado Projeto Senador Nilo Coelho $(11,1 \%)$ estavam impróprias para consumo, em virtude dos niveis de metamidofós encontrados. A situação da produção de Camocim de São Félix foi mais grave, visto que $53,1 \%$ das amostras de tomate $(n=17)$ violaram 0 estabelecido pela nossa legislação, com níveis não permitidos para o organofosforado metamidofós e o organoclorado endosulfan.

Em estudo realizado por Carvalho em 1996, ficou evidenciado que, no periodo 1980 a 1994, o Vale do Săo Francisco, mais especificamente a agricultura irrigada e a exportação de frutas foram responsáveis pela maior produção de trabalhos cientificos em relação a outras áreas do Estado de Pernambuco. As zonas da Mata e Agreste, onde se situa o Municipio de Camocim de Săo Félix, apresentaram o menor indice de estudos técnico-científicos.

$\mathrm{Na}$ atual legislaçăo brasileira constam mais de 75 principios ativos de praguicidas de origem química registrados para uso na cultura do tomate. Na sua maioria, são inseticidas, fungicidas, acaricidas e herbicidas (ILSI-Brasil, 1996; Coordenaçảo de Fiscalização de Agrotóxicos-AGROFIT, 1997). Ainda assim, o uso de outros produtos com registro não autorizado para o tomateiro é prática comum, conforme foi observado no desenvolvimento deste trabalho. A situação é agravada pelo 
fato de não existir qualquer tipo de controle sistemático de residuos de praguicidas nos alimentos ou dos produtos comercializados no Estado e de serem poucas as campanhas efetivas na orientação, no apoio e na educação dos produtores envolvidos.

Em outras palavras, o problema em estudo é complexo, e, para uma avaliação, deve-se considerar, entre outras questões, se: 1) as quantidades utilizadas são adequadas para uma determinada praga; 2) há excesso na aplicação e, portanto, maior exposição ocupacional e possibilidade de residuos tóxicos no alimento e ambiente; 3 ) as quantidades pulverizadas estão abaixo da dose efetiva para fungos e bactérias, o que apenas estaria tornando-os mais resistentes; 4 ) o periodo de carência está sendo respeitado; 5) ocorre contaminação dos aplicadores, inclusive de crianças da familia que colaboram no campo.

O monitoramento de praguicidas em alimentos possibilita a avaliação da qualidade da produçăo agricola, de tendências de aumento de uso desses produtos e da fonte de contaminação, além de fornecer dados para permitir que medidas preventivas e de controle possam ser efetuadas, antes que a contaminação se torne um risco para a saúde pública ou cause grandes perdas econômicas (Barretto e col., 1996). É importante um levantamento de dados que permitam conhecer qual a ingestão diária de residuos de praguicidas nos diferentes centros populacionais. Porém, deve-se ter em mente que os dados laboratoriais são limitados; nem sempre as amostras são representativas de uma determinada situação de risco, devido ao pequeno número de amostras analisadas, à restrição das classes analisadas, de transporte e acondicionamento (Garcia, 1996). 
Os processos produtivos praticados na agricultura atingiram um determinado nivel de dependência de praguicidas que, ainda por muitos anos, a população mundial estará vulnerável aos seus possiveis efeitos nocivos. Segundo Gravena (1997), a previsão para o próximo século é de que todas as pragas e doenças estarão em todas as partes do mundo devido à globalização e aos meios de comunicação e transporte cada vez mais eficientes e rápidos; outra preocupação é a de que o uso de praguicidas seja crescente em volume e área, o que causaria um impacto ambiental negativo e irreversivel (Gravena, 1997).

Aproximadamente 2,5 milhões de toneladas/ano de praguicidas já são aplicadas na agricultura mundial e movimentam 20 bilhōes de dólares. É significante a contribuição desses produtos para a manutenção da produção de alimentos. As estimativas indicam que as perdas com pragas aumentariam $10 \%$, se náo fosse utilizado qualquer tipo de praguicida, e algumas culturas especificas teriam perda de até $100 \%$. A maior parte dos benefícios, no entanto, baseia-se somente no retorno direto da colheita, não inclui os custos ambientais e de saúde pública indiretos associados aos praguicidas (Pimentel e col., 1992).

Condenar sumariamente o uso de praguicidas pode não ser, ainda, uma postura realista, visto que as alternativas, existentes em pequenas escalas, necessitam de mais apoio para poder alcançar os niveis desejados de produção agricola. O objetivo deve ser, portanto, usá-los racional e adequadamente, adotando politicas que reduzam, consideravelmente, o custo humano e ambiental.

- Sistema Nacional de Informações Tóxico-farmacológicas (SINITOX, 1995) registrou, no período de 1993 a 1995, um crescimento de 
cerca de $18,2 \%$ ao ano das intoxicações por praguicidas no pais. Foram registrados, nesse mesmo periodo, 150.224 casos de intoxicações, dos quais $8,6 \%$ relacionavam-se com os praguicidas, que ocupam a terceira posição dentre os demais agentes tóxicos. Dos 1.040 óbitos registrados, $36,5 \%$ referem-se aos praguicidas, que ocupam o primeiro lugar e estão entre os três principais agentes tóxicos relacionados aos óbitos para todas as faixas etárias (Bortoletto e Bochner, 1997).

As intoxicações agudas por praguicidas, em determinadas regiōes do pais, estão bem definidas e em outras são totalmente sub-registradas. $\mathrm{Na}$ região Nordeste, no ano de 1993, foram diagnosticados 10.223 casos de intoxicações agudas, dos quais 1.069 ocorreram no estado de Pernambuco; em relaçāo aos praguicidas, foram registrados apenas 307 casos de intoxicações agudas e nenhum deles foi considerado acidente de trabalho, conforme dados do SINITOX de 1993. Em 1995, foram registrados 9.254 casos de intoxicações na região Nordeste, dos quais 536 relacionavam-se ao uso de praguicidas e apenas 50 foram considerados de origem profissional (SINITOX, 1995).

Os programas de treinamento e qualidade de mão-de-obra, implantados pelas administrações regionais do Serviço Nacional de Aprendizagem Rural (SENAR), têm proposto medidas para contornar as dificuldades no uso de praguicidas, oferecendo segurança aos aplicadores e preservação ambiental, e representam uma das poucas iniciativas dirigidas para o trabalhador (Góis, 1996).

No entanto, a falta de regulamentação observada no trabalho rural é uma das maiores dificuldades para as medidas de proteção, uma vez que a lei se aplica aos trabalhadores formais 
No Brasil, existem normas regulamentando o uso de praguicidas na agricultura, mas, salvo em alguns estados, que dispõem de fiscalização efetiva, a obediência às leis ainda esbarra em questões sócio-culturais particulares de cada realidade; a contribuição no âmbito do laboratório de análise de residuos é importante quando acompanha politicas que buscam tratar o problema dentro de sua globalidade. 
7 - CONCLUSÕES 
De acordo com os resultados obtidos neste trabalho, foi possivel concluir que:

- os métodos validados para a análise de residuos de inseticidas organoclorados e organofosforados em tomate foram satisfatórios, segundo os limites toleráveis estabelecidos pela legislação vigente;

- a utilização do detector eletroquimico acoplado à cromatografia a liquido será importante para determinar niveis mais baixos de residuos de ETU em tomates: $67,8 \%$ das amostras totais apresentaram residuos de ETU, porém apenas $6,8 \%$ foram quantificadas com segurança;

- os dados obtidos neste estudo, em laboratório e nos levantamentos realizados, poderão orientar futuras ações de avaliação e monitoramento de produtos oriundos da agricultura local e orientar a seleção de métodos multi-residuos ou seletivos a serem implementados;

- $11,1 \%$ das amostras provenientes da produção de tomate industrial estavam impróprias para consumo, em virtude dos niveis de metamidofós encontrados; a situação da produção de tomate de mesa foi mais grave, visto que $53,1 \%$ das amostras de tomate violaram o estabelecido pela legislação brasileira, com valores acima do permitido para o inseticida organofosforado metamidofós e a presença ilegal do organoclorado endosulfan;

- os trabalhos rurais de cultura do tomate apresentaram caracteristicas sócio-ambientais desfavoráveis para a qualidade de vida dos individuos envolvidos; a morbidade referida foi compativel com o quadro clinico esperado para expostos a praguicidas; 
- a implantação do laboratório de análise de resíduos de praguicidas na rede estadual foi um passo de extrema importância para as açōes de programas de vigilância à saúde e ambiental; o Estado, hoje, encontrase apto para responder às demandas de monitoramento e controle de residuos de praguicidas em alimentos, de certificação de produção limpa, o que contempla nesse processo a saúde do trabalhador e da populaçăo em geral e a preservação do meio ambiente. 
ABAKERLI, R. Amostragem e sua influência nos resultados de residuos. In: Encontro Nacional de Analistas de Residuos de Pesticidas, $15^{\circ}$, São Paulo, 1991. Resumos. São Paulo, Instituto Adolfo Lutz, 1991. p. 30 43.

ALMEIDA, J.A. \& SOARES, D.M. Análise de variáveis sociais na questão do uso dos agrotóxicos: o caso da fumicultura. Ciênc. Amb., 3: 85-104, 1992.

ALMEIDA, M.E.W. \& BARRETTO, H.H.C. Residuos de pesticides clorados em leite consumido em Săo Paulo. Rev.Inst.Adolfo Lutz, 31:13-20, 1971.

ALMEIDA, W.F. Intoxicação pelos modernos inseticidas. Rev. Paul. Med., 55: $380-94,1959$.

AMBRUS, A. The influence of sampling methods and other field techniques on the results of residue analysis. In: Geiss-Bühler,H., ed. Advance in pest science. Pergamon Press, 1978. p.620-32.

AMERICAN VEGETABLE GROWER. EBDC decision: sound science. Washington, 1992.

ANDRADE, M.J.F.V. Economia do meio ambiente e regulamentação: análise da legislação brasileira sobre agrotóxicos. Rio de Janeiro, 1995. [Dissertação de Mestrado - Escola de Economia da Fundação Getúlio Vargas].

ANKUMAH,R.O. \& MARSHALL,W.D. Persistence and fate of ethylenethiourea in tomato sauce and paste. J. Agric. Food Chem., 32:1194-8, 1984.

ANUÁRIO ESTATÍSTICO DE PERNAMBUCO: 1992. Recife, Instituto de 
Planejamento de Pernambuco, 1995. v.41.

ARAÚJO, A. C. P. \& GORNI, R. Determinação de ETU por cromatografia líquida: validação de metodologia. In: Congresso Brasileiro de Toxicologia, 9, Ribeirão Preto, 1995. Anais. São Paulo, Sociedade Brasileira de Toxicologia, 1995. p. 135.

ARAÚJO, A. C. P.; KYT, S.N.V.; TELLES, D. L. Exposição ocupacional a agentes químicos em indústrias do Estado de Pernambuco. Rev.Bras. Saúde Ocupac., 80: 45-49, 1993.

ARAÚJO, A. C. P.; RIBEIRO, R. D. Estudos dos niveis de nitratos e nitritos em linguiças comercializadas na cidade de Recife. Rev. Bras. Toxicol., 5: $17-18,1992$.

ARAújo, A. C. P.; TElles, D. L.; ALMEIDA, M.G.; NASCIMENTO, E.S. Determinacion de aflatoxinas en cacahuetes comercializados en Recife. Alimentaria, 249: 35-37, 1994.

ARAÚJO, A. C. P.; TELLES, D. L.; GORNI, R.; LIMA, L. A. Organochlorine pesticides contamination in the Ipojuca Basin, Brasil. Environ. Technol., 19: $109-113,1998$.

ARGERICH, C. A.; MELO, P. C. T.; VALDERRAMA, L. A. Update on the agro-industry situation of processing tomatoes in South American countries. In: International Conference on the Processing Tomato, $1^{\text {st }}$, Recife, 1996. Proceedings. Alexandria, ASHS Press, 1997.p.15-21.

ASSOCIAÇÃO NACIONAL DE DEFESA VEGETAL - ANDEF. Vendas de defensivos agricolas 1995/1996. São Paulo, 7p.[Mimeografado]

BARRETTO, H.H.C.; INOMATA, O.N.K.; LARA. W.H. Determinação de fosfina em alimentos. Rev.Inst.Adolfo Lutz, 44: 149-153, 1984. 
BARRETTO, H.H.C.; INOMATA, O.N.K.; LEMES, V.R.R. Niveis de pesticidas organoclorados em gordura de frango, 1988-1991. Rev.Inst.Adolfo Lutz, 52: 97-100, 1992.

BARRETTO, H.H.C.; INOMATA, O.N.K.; LEMES, V.R.R.; KUSSUMI, T.A.; SCORSAFAVA,M.A.; ROCHA, S.O.B. Monitoramento de residuos de pesticidas em alimentos comercializados no Estado de São Paulo em 1994. Pestic. Rev. Téc. Cient., 6: 1-12, 1996.

BATISTA, G. C. Orientação para estudos de residuos - amostragem. In: Encontro de Analistas de Residuos de Pesticidas, 10, São Paulo, 1986. Anais. São Paulo, GARP, 1986. p.40-53.

BIECHE, B. Update on the agro-industry situation of processing tomatoes in the AMITOM countries. In: International Conference on the Processing Tomato, $1^{\text {st }}$, Recife, 1996. Proceedings. Alexandria, ASHS Press, 1997. p.2-9.

BOLZONI, L.; SANNINO,A.; BANDINI,M. Determination of ethylenethiourea and propylenethiourea in tomato products and in fruit purees. Food Chem., 47: 299-302,1993.

BORTOLETTO, M. E. \& BOCHNER, R. Intoxicações por agrotóxicos no Brasil: uma análise das tendências no periodo de 1993 a 1995 . Rev. Bras. Toxicol., 10: 23, 1997. (Suplemento).

BOTTOMLEY, P.; HOODLESS, R. A.; SMART, N. A. Review of methods for the determination of ethylenethiourea (imidazolidine-2-thione) residues. Res. Rev., 95: 45-89, 1985.

BRANCO, E. P. Construção do fosso para descarte de embalagens de agrotóxicos. Lavoura: 16-7, set/out, 1994. 
BULL, D. \& HATHAWAY, D. Pragas e venenos: agrotóxicos no Brasil e no Terceiro Mundo. Rịo de Janeiro, Vozes/OXFAM/FASE, 1986.

CACCIALANZA, G.; GANDINI, C.; ROGGI, C.; ZECCA, E. Determinazione diretta di 2-imidazolidietione(ETU) in matrici alimentari mediante cromatografia liquida ad alta pressione (HPLC). Farmaco, 35: 449. 1980.

CACCIALANZA, G.; GANDINI, C.; ROGGI, C.; ZECCA, E. Detection and determination of ethylenethiourea in grapes and wine. Farmaco, 36: $73,1981$.

CALUMPANG, S. M. F.; MEDINA, M. J. B.; ROXAS, N. P.; MAGALLONAS, E. D. Movement and degradation of mancozeb fungicide and its metabolites, ethylenethiourea and ethyleneurea in silty clay loam soil. Int. J. Pest Manag., 39:161-6, 1993.

CAMONI, I.; MUCCUI, A.; PONTECORVO, D.; CITTI, P. Survey of ethylenethiourea (ETU) in ethylenebisdithiocarbamate (EBDC) fungicides. Ecotoxicol. Environ. Saf., 16: 176-9, 1988.

CANOSSA, E.; ANGIULI, G.; GARASTO, G.; BUZZONI, A.; DE ROSA, E. Indicadori di dose in agricoltori esposti a mancozeb. Med. Lav., 84: 42-50, 1993.

CARVALHO, J.P.; NISHIKAWA, A.M.; ARANHA, S.; FAY, E.F. Residuos de praguicidas organoclorados em gordura bovina. Biológico, 50: 39-48, 1984.

CARVALHO, J.P.; NISHIKAWA, A.M.; FAY, E.F. Niveis de residuos de praguicidas organoclorados em produtos cárneos sob inspeção federal. Rev. Saúde Públ., 14: 408-419, 1980. 
CARVALHO, M. A. A questão alimentar em Pernambuco à luz da ciência da informação. Rio de Janeiro, 1996. [Dissertação de Mestrado - Escola de Comunicação da Universidade Federal do Rio de Janeiro].

CENTRO PANAMERICANO DE ECOLOGIA HUMANA Y SALUD. Plaguicidas inhibidores de las colinesterasas. México, 1991. (OMS - Serie Vigilancia, 11).

CHASIN, A. M.; CHASIN, M.; SALVADORI, M. C. Validação de métodos cromatográficos em análises toxicológicas. Rev. Farm. Bioquim. Univ. S. Paulo, 30:49-53,1994.

CHEAH, U. B. Mancozeb residues in highland and lowland tomatoes. Mardi Res. Bull., 13: 279-83, 1985.

CIENTEC. Controle sistemático de residuos de defensivos agricolas em trigo e soja. Fundação de Ciência e Tecnologia do Rio Grande do Sul, 1981.

COMISION DEL CODEX ALIMENTARIUS, Las Haya, 1995. Report: Residuos de plaguicidas presentes en alimentos y piensos. Rome, Organizacion Mundial de la Salud, 1995. (WHO - CX/PR 96/5 - Parte A, $28^{a}$ reunión).

COMPANHIA DE ABASTECIMENTO E DE ARMAZÉNS GERAIS DO ESTADO DE PERNAMBUCO - CEAGEPE. Análise conjuntural de mercado a nivel de atacado na unidade CEASA-PE. Secretaria de Agricultura, Recife, 1996.

COMPANHIA DE DESENVOLVIMENTO DO VALE DO SÃO FRANCISCOCODEVASF. Brasil: Contratos de Empréstimo 576/SF-BR e 350/OCBR, Brasilia, 1989. Projeto de Irrigação Vale do Massangano (Senador 
Nilo Coelho) - Avaliação Ex-Post.

COMPANHIA DE DESENVOLVIMENTO DO VALE DO SÃO FRANCISCOCODEVASF. $3^{\text {a }}$ Superintendência Regional, Petrolina, 1996. Informações Técnicas, Petrolina, 1996. (Relatório Anual).

COORDENAÇÃO DE FISCALIZAÇÃO DE AGROTOXICOS - AGROFIT/97.

Sistema de Produtos Fitossanitários. Brasilia, 1997, Ministério da Agricultura e do Abastecimento.

DAL PIVA, G.G.S.; MIRANDA, L.A.S.; DAL PIVA, S.L. Pesquisa de ETU em batatas inglesas da regiāo de Silveira Martins, RJ. In: Congresso Brasileiro de Toxicologia, $9^{\circ}$, Ribeirão Preto, 1995. Anais. São Paulo, Sociedade Brasileira de Toxicologia, 1995. p.137.

DEARFIELD, K. L. Ethylenethiourea (ETU): a review of the genetic toxicity studies. Mutat. Res., 317:111-32, 1994.

DINHAM, B. The pesticide hazard: a global health and environmental audit. London, Zed Books, 1993.

DISERENS, $H$. Determination of ethylene thiourea in various foods. Lausanne, Nestle, 1991.[Laboratory news, 62].

DOERGE, D. \& YEE, A. B. K. Liquid chromatographic determination of ethylenethiourea using pulsed amperometric detection. J. Chromatogr., $586: 158-60,1991$.

DURVAL, G. Investigación disciplinaria y enfoque sistémico. Avance y Perspectiva, 12: 67-75, 1993

DUTCH MINISTRY OF PUBLIC HEALTH, WELFARE AND SPORT. GeneraI Inspectorate for Health Protection. Analytical methods for pesticide 
residues in foodstuffs - Part I. Amsterdan, 1996.

ELIA, M. C.; ARCE, G.; HURT, S. S.; NEILL, P. J.; SCRIBNER, H. E. The genetic toxicology of ethylenethiourea: a case study concerning the evaluation of a chemical's genotoxic potential. Mut. Res., 341: 141-9, 1995.

ENVIRONMENTAL PROTECTION AGENCY - EPA. EPA'S final EBDC decision draws support. Pestic. Toxic. Chem. News (19): 23-5, Feb.19, 1992.

FERRARI, A. Agrotóxicos: a praga da dominação. Porto Alegre, Mercado Aberto, 1985

FERREIRA, A. C.; SANTOS, R. O; MENEZES, D. Avaliação da resistência a murcha bacteriana (Pseudomonas solanacearum) em cultivares de tomateiro. In: Congresso de Iniciação Científica da UFRPE, $5^{\circ}$, Recife, 1995. Anais. Recife, Ed. UFRPE, 1995. p.76.

FERREIRA, H. S. Pesticidas no Brasil: impacto ambiental e possiveis conseqüências de sua interação com a desnutrição humana. Rer. Bras. Saúde Ocup., 80: 51-61, 1993.

FISCHER, L. R. \& MELO, L. A. O trabalho feminino: efeitos da modernização agricola. Recife, Massangana, 1996.

FOOD AND AGRICULTURE ORGANIZATION OF THE UNITED NATIONS FAO. Food, Nutrition and Agriculture. Rome, 1995a, vol.13/14, 1995.

FOOD AND AGRICULTURE ORGANIZATION OF THE UNITED NATIONS, FAO yearbook: production. Rome, 1995b. vol. 48. (FAO Statistics Series, 125). 
FOOD AND DRUG ADMINISTRATION. Pesticide Program. Washington, 1993 (FDA - Residue monitoring, 1993).

FRAKES, R. A. Drinking water guideline for ethylenethiourea, a metabolite of ethylenebisdithiocarbamate fungicides. Regul. Toxicol. Pharmacol., 8: $207-18,1988$.

FRANÇA, J. G. E. \& ARRUDA, G. Conferencia magistral: biologia, cría y uso de los enemigos naturales para el control de Bemisia tabaci (Biotipo B). [Apresentado ao VI Taller Latinoamericano y del Caribe sobre Moscas Blancas y Germinivirus, Santo Domingo, República Dominicana, 1997].

FRANEKIE, J.; BRATULIE, N.; PAVLICA, M.; PAPES, D. Genotoxicity of dithiocarbamates and their metabolites. Mut. Res., 325: 65-74, 1994.

FUNDAÇÃo IBGE. Anuário Estatístico do Brasil. Rio de janeiro, 1994. v. 49 .

FUNDACENTRO. Projeto de avaliação e prevenção de intoxicação por agrotóxicos. Petrolândia, Santa Maria da Boa Vista e Vitória de Santo Antão - Relatório de análise de dados. Recife, 1996. [Mimeografado]

GARCIA, E. G. Segurança e saúde no trabalho rural com agrotóxicos: contribuição para uma abordagem mais abrangente. São Paulo, 1996. [Dissertação de Mestrado - Faculdade de Saúde Pública da USP].

GEBARA, A. B.; FERREIRA, M.S.; CISCATO, C.H.P.; SANTIAGO, M.R. Residuos de agrotóxicos em frutas comercializadas na CEAGESP. In: Congresso Brasileiro de Toxicologia, $9^{\circ}$, Ribeirāo Preto, 1995. Anais. São Paulo, Sociedade Brasileira de Toxicologia, 1995. p. 144.

Gois, J. M. Defensivos agricolas. A granja, 52: 46-8, 1996. 
GRAVENA, S. Impacto ambiental do uso de praguicidas. Rev. Bras. Toxicol, 10:5, 1997. (Suplẹmento).

GREVE, P. A. \& HERBOLD, H .A. A simple HPLC procedure for the determination of ethylenethiourea (ETU) in cooked vegetables. Meded. Fac. Landbouwwet. Rijksuniv. Gent, 48: 933-5,1983.

GUINDANI, C. M. A. \& UNGARO, M. T. S. Avaliação de residuos de dicofol e endosulfan em morangos comercializados. Biológico, 54: 53-4, 1988.

HAJI, F. N. P. Ações para o problema da traça do tomateiro na região do submédio Sáo Francisco. In: Encontro sobre manejo de pragas do tomateiro, $1^{\circ}$, Petrolina, 1989. Anais. Petrolina, Ed. EMBRAPA/ CPATSA, 1989. p. 1-9 (Documentos, 65).

HOFFMANN, W. Organochlorine compounds: risk of non-Hodgkin's lymphoma and breast cancer? Arch. Environ. Heal., 51: 189-192, 1996.

HOGENDOORN, E. A.; van ZOONEN, P.; BRINKMAN, U. A. Columnswitching RPLC for the trace-level determination of ethylenethiourea in aqueous samples. Chromatographia, 31: 285-92, 1991.

INSTITUTO TECNOLOGICO DO ESTADO DE PERNAMBUCO - ITEP. Estudo da qualidade da água do Municipio de Camocim de São Félix. Recife, 1997 (Relatório técnico, 5923).

INTERNATIONAL AGENCY FOR RESEARCH ON CANCER - IARC. Genetic and related effects. IARC Monogr. Eval. Carcinog. Risk Hum. Supp.,6: 304-7, 1987.

INTERNATIONAL LIFE SCIENCES INSTITUTE - ILSI. Relação de substâncias para uso fitossanitário e domissanitário -Portarias do Ministério da Saúde. São Paulo, 1995, Seller Comunicação, 716p. (ILSI 
Brasil - monografias).

INTERNATIONAL UNION OF PURE AND APPLIED CHEMISTRY - IUPAC Comissão de residuos de praguicidas da comissão de química aplicada da IUPAC (IUPAC, 1977) IUPAC. Ethylenethiourea. Pure Appl. Chem, 49: 675,1977 .

JOINT MEETING OF THE FAO PANEL OF EXPERTS ON PESTICIDE RESIDUES IN FOOD AND THE ENVIRONMENT AND THE WHO EXPERT GROUP ON PESTICIDE RESIDUES - JMPR, Geneve, 20-29 September, 1993. Report. Food and Agriculture Organization of the United Nations plant production and protection (FAO - paper 122, 1994).

JOINT MEETING OF THE FAO WORKING PARTY OF EXPERTS AND THE WHO EXPERT COMMITTEE ON PESTICIDE RESIDUES - JMPR, ROME, 1974. Report: Pesticides residues in food. Geneva, World Organization, 1975. (WHO - Technical Report Series, 574; FAO - Agricultural Studies, 17).

JONHSON, E.I. \& TYLER, J.F.C. Occurence of ethylenethiourea in thiocarbamate fungicides and its detection in fruit juice. Chem. Ind., 5: $305,1962$.

KING, R.R. Derivatization of ethylenethiourea with m-trifluoromethylbenzyl chloride for analysis by electrocapture gas chromatography. J. Agric. Food Chem., 25: 73-5, 1977.

KOBAYASHI, H.; NISHIDA, M.; MATANO, O.; GOTO, S. Effect of cysteine on the stability of ethylenethiourea and ethylenebisdithiocarbamate in crops during storage and/or analysis. J. Agric. Food Chem., 40: 76-80, 
1992.

KRATOCHVIL, B. Sampling for chemical analysis of the environment: Statistical considerations. In: Kurtz, D. A., ed. Trace residue analysis: chemometric estimations of amount uncertainty and error, Philadelphia, American Chemistry Society, 1985. [ACS Symposium Series, 284].

KRATOCHVIL, B. General principles of sampling. In: Sampling and Calibrations for Atmospheric Measurements - ASTM STP 957. Philadelphia, J.K.Taylor Ed., 1987. p.5-13.

KRATOCHVIL, B. \& PEAK, J. Sampling techniques for pesticides analysis. In: Sherma, J., ed., Analytical methods for pesticides and plant growth regulators. New York, Academic Press, 1989, vol. 17, p.1-33.

KRAUSE, R. T. Liquid chromatographic-electrochemical determination of ethylenethiourea in foods by revised official method. J. Assoc. Off. Anal. Chem, 72: 975-9,1989.

KRAUSE, R. T. \& WANG, Y. Liquid chromatographic-electrochemical technique for determination of ethylenethiourea residues. J. Liq Chromatogr., 11: 349-62,1988.

KUMAR, U. \& AGARWAL, H. C. Degradation of Dithane M-45 residues in brinjals during cooking. Bull. Environ. Contam. Toxicol, 47: 725-31, 1991.

KUMAR, U. \& AGARWAL, H. C. Fate of $\left[{ }^{14} \mathrm{C}\right]$ mancozeb in egg plants (Solanum melongena L.) during summer under sub-tropical conditions. Pestic.Sci., 36:121-5, 1992.

KURTTIO, P. \& SAVOLAINEN, K. Ethylenethiourea in air and in urine as an indicator of exposure to ethylenebisdithiocarbamate fungicides. Scand 
J. Work Environ. Health, 16: 203-7, 1990.

KURTTIO, P.; VARTIAINEN, T.; SAVOLAINEN, K. A high performance liquid chromatographic method for the determination of ethylenethiourea in urine and on filters. Anal. Chim. Acta, 212: 297 301,1988 .

KURTTIO, P.; VARTIAINEN, T.; SAVOLAINEN, K. Environmental and biological monitoring of exposure to ethylenebisdithiocarbamate fungicides and ethylenethiourea. Br. J. Ind. Med., 47: 203-6, 1990.

KURTTIO, P.; VARTIAINEN, T.; SAVOLAINEN, K. Measurement of ethylenethiourea using thermospray liquid chromatography-mass spectrometry. J. Anal. Toxicol., 16: 85-7, 1992.

LARA, W. A. Tolerância tem limites. Ciênc. Cult., 4: 63-4, 1986.

LARA, W. A. Laboratório de análise de residuos de pesticidas no Brasil. In: Encontro Nacional de Analistas de Residuos de Pesticidas, $13^{\circ}$, São Paulo, 1988. Resumos. São Paulo, Instituto Adolfo Lutz, 1988. p. 4253.

LARA, W.H. \& BARRETTO, H.H.C. Resíduos de pesticidas clorados em águas. Rev.Inst.Adolfo Lutz, 32: 69-74, 1972a.

LARA, W.H. \& BARRETTO, H.H.C. Residuos de pesticidas clorados em alimentos. Rev.Inst.Adolfo Lutz, 32: 89-94, 1972b.

LARA, W.H.; BARRETTO, H.H.C.; INOMATA, O.N.K. Variação dos niveis de residuos de pesticides organoclorados em leite consumido na cidade de Sảo Paulo em 1979. Rev.Inst. Adolfo Lutz, 40: 65-74, 1980 a.

LARA, W.H.; BARRETTO, H.H.C.; INOMATA, O.N.K. Niveis de BHC e DDT 
em peixes, camaröes e ostras do litoral de Santos, Estado de São Paulo. Rev.Inst.Adolfo Lutz, 40: 29-33, 1980 b.

LARA, W.H.; BARRETTO, H.H.C.; INOMATA, O.N.K. Residuos de pesticidas organoclorados em leite humano, São Paulo, Brasil, 19791981. Rev.Inst.Adolfo Lutz, 42: 45-52, 1982.

LARA, W.H.; BARRETTO, H.H.C.; INOMATA, O.N.K. Variação dos niveis de residuos de pesticides organoclorados em leite pasteurizado tipo B, distribuidos na cidade de São Paulo, de 1980 a 1981. Rev.Inst.Adolfo Lutz, 45:43-52, 1985.

LARA, W.H.; BARRETTO, H.H.C.; TAKAHASHI, M. Y. Residuos de pesticidas clorados em conservas de carne bovina. Rev.Inst.Adolfo Lutz, 31: 63-70, 1971.

LARINI, L. Toxicologia.2 ed. Sảo Paulo, Manole, 1993.

LEHOTAY, J.; BRANDSTETEROVA, E.; OKTAVEC, D. High-performance liquid chromatographic determination of ethylenethiourea in food. $J$ Liq. Chromatogr., 15: 525-34, 1992.

LEHOTAY, J. \& KISOVA, D. HPLC study of mancozeb degradation on leaves. J. Liq. Chromatogr., 16: 1015-22, 1993.

LEMES, V. R. R.; INOMATA, O. N. K; BARRETTO, H. H. C. Resíduos de endosulfan em tubérculos e frutos. Rev. Inst. Adolfo Lutz, 53: 49-54, 1993.

LISI, P. \& CARAFFINI, S. Pellagroid dermatitis from mancozeb with vitiligo. Contact Dermatitis, 13: 124-5, 1985.

LISKA, E. R.; BROUWER, A. G.; OSTHEIMER, H.; LINGEMAN, H.; 
BRINKMAN, U. A. Rapid screening of a large group of polar pesticides in river water by on-line trace enrichment and column liquid chromatography. Intern. J. Environ. Anal. Chem., 47: 267-91, 1992.

LOMBARDI, J. V.; GARCIA, A. L. B.; MACHADO NETO, J. G.; KUBO, E.; BOOCK, M. V. Toxicidade aguda dos pesticidas Gesapax-500 (ametrina) e Thiodan-CE (endosulfan) para o camarão de água doce Macrobrachium rosenbergii. Rev. Bras. Toxicol., 10: 83, 1997. (Suplemento).

LONGBOTTOM, J. E.; EDGELL, K. W.; ERB, E. J.; LOPEZ-AVILA, V. Gas chromatographic/nitrogen-phosphorus detection method for determination of ethylenethiourea in finish drinking waters: collaborative study. J. AOAC, 76: 1113-20, 1993.

LUKE, M. A.; FROBERG, J. E.; MASUMOTO, H. T. Extraction and cleanup of organochlorine, organophosphate, organonitrogen and hydrocarbon pesticides in produce for determination by gas-liquid chromatography. J. $A O A C, 58: 1020-6,1975$.

LUNA, A. J.; TEXEIRA, M. C.; CORREIA, M.; DANTAS, R. C.; MOURA, V. V. R. Resultados e açōes de prevenção de intoxicação por organofosforados e carbamatos da campanha "Agrotóxicos: responsabilidade de todos". São Paulo, FUNDACENTRO, 1992. [Apresentado ao $1^{\circ}$ Seminário de Destinação de Embalagens de Agrotóxicos no Estado de Pernambuco, Recife, 1995].

MAIA, R. \& BRANT, P. C. Estudo comparativo da contaminação da carne bovina por residuos de pesticidas clorados, nas regiós do Estado de Minas Gerais, Brasil. Rev.inst.Adolfo Lutz, 40: 15-21, 1980. 
MARSHALL, W. D. Preprocessing oxidative washes with alkaline hypochlorite to remove ethylenebis(dithiocarbamate) fungicide residues from tomatoes and greenbeans. J. Agric. Food. Chem., 30: 649-52 1982.

MARUYAMA, M. Residue analysis of ethylenethiourea in vegetables by high-performance liquid chromatography. Fresenius J. Anal. Chem, 348: $324-6,1994$.

MASSEY, P.; KEY, P. E.; MCWEENY, D. J. Analysis of ethylenethiourea in beer by high-performance liquid chromatography. J. Chromatogr., 240 254-6, 1982.

MATSOVA, E.; CHOVANCOVA, J.; BUZINKAIOVA, T. Capillary gas chromatography of ethylenethiourea, a degradation product of ethylenebis(dithiocarbamates). J. Chromatogr., 286: 331, 1984.

MEIRING, H. D. \& DE JONG, A. P. J. M. Determination of ethylenethiourea in water by single-step extractive derivatization and gas chromatography-negative ion chemical ionization mass spectrometry. $J$. Chromatogr. A, 683: 157-65, 1994.

MELO, L. A. Reprodução da subordinação de gênero: o caso da mulher trabalhadora rural de empresas de uva do submédio São Francisco. Recife, 1997. [Dissertação de Mestrado - Departamento de Administração Rural e Comunicação Rural da Universidade Federal Rural de Pernambuco].

MERCOSUR. Residuos de plaguicidas en produtos agricolas in natura: MERCOSUR/GMCIRES, 23/54. In: Associação Brasileira da Indústrias de Alimentos. Compendio Mercosul: legislação alimentos e bebidas. 
Sāo Paulo, ABIA, 1995.

MESTRES, R. \& MESTRES, G. Ethylenebisdithiocarbamate and ethylenethiourea residues in food. Rev. Bras. Toxicol., 4: 11-8, 1991.

MITCHELL, L.R. Collaborative study of the determination of endosulfan, endosulfan sulfate, tetrasul and tretradifon residues in fresh fruits and vegetables. J.Asso. Off.Anal.Chem., 59: 209-212, 1976.

MOZA, P. N. \& HUSTERT, K. An attempt to separate ethylenethiourea and ethyleneurea, degradation products of et hylenebis(dithiocarbamates), using HPLC. Radiotracer studies of fungicide residues in food plants. IAEA TeC. DOC., 554: 107-10, 1989.

MURPHY, S.D. Toxic effects of pesticides. In: Casarett and Doull"s toxicology - the basic science of poisons. 3 ed., New York, McMillan, 1986. p.519-81.

NASCHENVENG, R. A. Conseqüências sociais da utilização de defensivos agricolas. Rev. Bras. Saúde Ocup., 41: 7-13,1983.

NASH, R. G. Gas liquid chromatographic method for determining ethylenethiourea in plants. J. AOAC., 58: 566-71, 1975.

NATIONAL FOOD ADMINISTRATION (NFA). Pesticides residues in food of plant origin, 1994. Uppsala, 1995. (Rapport 20/95).

NATIONAL INSTITUTES OF HEALTH (NIH). National Toxicology Program. Toxicology and carcinogenesis studies of ethylenethiourea in F344/N rats and B6C3F1 mice (feed studies). Washington, DC, 1992. (NIH Publication, 92-2843; National Toxicology Program Technical Report Series, 388). 
NEBBIA, C.; FERRERO, E.; VALENZA, F.; CASTAGNARO, M.; RE, G.; SOFFIETTI, M. G. Pathologic changes, tissue distribution and extent of conversion to ethylenethiourea after subacute administration of zinc ethylene-bis-dithiocarbamate (zineb) to calves with immature rumen function. Am. J. Vet. Res., 52: 1717-22,1991.

NEIL, G. D. \& WILLIAMS, J. S. Ethylenethiourea in Maine ground water. Report, 1990. Department of Conservation, Maine Geological Survey, Augusta, 1990.

NEWSOME, W. H. Determination of ethylenethiourea residues in apples. J. Agric. Food Chem., 20: 967-9, 1972.

NISHIKAWA, A.M.; FAY, E.F.; CARVALHO, J.P.; ARANHA, S. Niveis de residuos de praguicidas organoclorados em conservas de carne bovina. Biológico, 48: 189-193, 1982.

NITZ, S.; MOZA, P. N.; KORTE, F. Capillary gas liquid chromatographic method for determination of ethylenethiourea and propylenethiourea in hops, beer and grapes. J. Agric. Food Chem., 30: 593,1982.

OLIVEIRA, J.J.V. \& TOLEDO, M.C.F. Residuos de agrotóxicos em morangos. Pest.Rev. Tec. Cient., 5: 95-100, 1995.

ONLEY, J. H. \& YIP, G. Determination of ethylenethiourea residues in food, using thin layer and gas chromatography. J. AOAC., 54: 165-9, 1971.

PAESE, H. L. \& HOLT, R. F. Manganese ethylenebis (dithiocarbamate) (maneb)/ethylenethiourea (ETU) residues studies on five crops treated with ethylenebis (dithiocarbamate) (EBDC) fungicides. J. Agric. Chem., 25: $561-7,1977$. 
PAN AMERICAN HEALTH ORGANIZATION - PAHO. Pesticides and health in Americas. Washington, 1993. (Environmental Series, 12).

PELEGRÍ, R.; BELTRÁN, V.; COSCOLLÁ, R.; CUÑAT, P. La determinación de residuos de etilentiourea como indice de la contaminación de produtos agricolas por etilenbisditiocarbamatos. Rev. Agroquim. Tecnol. Aliment., 28: 415-20, 1988.

PELLACANI, M. A.; GUIDETTI, C.; RABITTI, T.; VANDELLI, F. Antiparassitari in viticoltura: Residui nel prodotto e contaminazione ambientale. Inf. Agrar., 14: 45-46, 1993.

PEROCCO, P.; COLACCI, A.; BONORA, B.; GRILLI, S. In Vitro transforming effect of the fungicides metalaxyl and zineb. Teratog. Carcinog. Mutagen., 14: 73-80, 1995.

PIMENTEL, D.; ACQUAY, H.; BILTONEN, M.; RICE, P.; SILVA, M.; NELSON, J.; LIPNER, V.; GIORDANO, S; HOROWITZ, A.; D'AMORE, M. Environmental and economic costs of pesticide use. Bioscience, 42: $750-60,1992$

PIMENTEL, D.; MCLAUGHLIN, L.; ZEPP, A.; LAKITAN, B.; KRAUS, T.; KLEINMAN, P.; VANCINI, F.; ROACH, W. J.; GRAAP, E.; KEETON, W.S.; SELIG, G. Environmental and economic effects of reducing pesticide use in agriculture. Agric. Ecosyst.Environ., 46: 273-88, 1993.

PLANET, N. Envenenamento produzido por inseticidas em operários rurais no combate às pragas d algodão. Rev. Paul. Med., 37: 59-60, 1950.

PRECHEUR, R. J.; Management of fungicide residues on processing tomatoes. Plant Dis., 76: 700-2, 1992.

PREZOTTI, L.; HAJI, F. N. P.; HONDA, O. T. ; ALENCAR, J. A.; ALENCAR, 
C. M. Seletividade de inseticidas utilizados no controle da traça-dotomateiro, Scrobipalpuloides absoluta, sobre Trichogramma pretiosum. em laboratório. In: Simpósio de Controle Biológico-Siconbiol, 5․ Foz do Iguaçu, 1996. Anais. Curitiba, EMBRAPA-CNPSo/COBRAFI, 1996. p. 373 .

REIS, M. R. C. S. \& CALDAS, L. Q. A. Dithiocarbamate residues found on vegetables and fruit marketed in the State of Rio de Janeiro, Brazil. Ciênc. Cult., 43: 216-8, 1991.

REPETTO, R. \& BALIGA, S. S. Pesticides and the immune system: the public health risks. Washington, World Resources Institute, 1996.

RINCON, A. R. Crucial factors affecting the processing tomato-growing system in relation to fruit quality and impact on the environment. In: International Conference on the Processing Tomato, $1^{\text {st }}$, Recife, 1996. Proceedings. Alexandria, ASHS Press, 1997.p.34-40.

RODRIGUES, D. C. Intoxicação por inseticidas. Biológico, 23: 137-40, 1957.

RODRIGUEZ, R. R., RODRIGUEZ, J. M. T., SAN JUAN, J. A. M. Cultivo moderno del tomate. 2a ed. Madrid, Mundi-Prensa Libros, 1997.

ROGERS, E.; TUFTS, K.; WESTBERG, G. L. Determination of ethylenethiourea in crops. Sacramento, Morse Laboratories, 1989. (Analytical method, MTF-88AM-004).

ROSS, M. A. \& LEMBI, C. A. Applied Weed Science. Minneapolis, Burgess Pub., 1985.

RÜEGG, E.F.; PUGA, F.R.; SOUZA, M.C.M.; ÜNGARO, M.T.S.; FERREIRA, M.S.; YOKOMIZO, Y.; ALMEIDA, W.R. Impacto dos agrotóxicos sobre o 
ambiente, a saúde $\theta$ a sociedade. $2^{\mathbf{a}}$ ed. São Paulo, İcone, 1991.

SCHWARTZMAN, S. Tratamento das intoxicações por inseticidas organofosforados. Rev. Paul. Med., 57: 107-15, 1960.

SECRETARIA DE CIENCIA, TECNOLOGIA E MEIO AMBIENTE - SECTMA.

Diretoria de Meio Ambiente. Programa Nacional de Meio Ambiente/Projetos de Execução Descentralizada - PNMA/PED. Desenvolvimento de sistemas florestais sustentáveis nos municipios de Gravatá, Bonito, Camocim de São Félix e Camaragibe. Recife, 1996.

SILVA, E. S.; CABRAL, J. B.; MENEZES, D. Recuperaçāo de embriōes hibridos de Lycopersicon esculentum Mill e sua utilização na obtenção de linhagens puras. In: Congresso de Iniciação Cientifica da UFRPE, $5^{\circ}$, Recife, 1995. Anais. Recife, Ed. UFRPE, 1995.p.110.

SILVA, J. N. Educação ambiental comunitária: alternativas para as zonas rurais - um estudo de caso. Cuiabá, 1991. [Monografia de Especialização em Educação Ambiental - Fundação Universidade Federal de Mato Grosso].

SING, H. J.; COCHRANEW, P.; SCOTT, J. Extractive acylation of ethylenethiourea from water. Bull. Environ. Toxicol., 23: 470-4, 1979.

SISTEMA NACIONAL DE INFORMAÇĀO TÓXICO-FARMACOLÓGICA SINITOX. Estatistica anual de casos de intoxicação e envenenamento Brasil - 1993. Fundação Oswaldo Cruz, 1995.

SOARES, I.A.A. Resultados de análises de residuos de inseticidas clorados e fosforados em frutas e hortaliças comercializadas no CEASA/MG e analisadas no Centro Integrado de Apoio à ProduçãoCIAP, 1983 a 1984. [Apresentado ao Encontro de Analistas de 
Resíduos de Pesticidas, São Paulo, 1985].

SOARES, I. A. A. Resíduos de inseticidas organoclorados em hortaliças e frutas. Belo Horizonte, 1986. [Dissertação de Mestrado-Departamento de Tecnologia de Alimentos da UFMG].

STINE, K. \& BROWN, T.M. Principles of toxicology. Boca Raton, CRC Press, 1996.

SULLIVAN, G. H. Economic performance, trade and competitive position in the North American tomato processing industry. In: International Conference on the Processing Tomato, $1^{\text {st }}$, Recife, 1996. Proceedings. Alexandria, ASHS Press, 1997.p.10-4.

TEIXEIRA, C.F. \& BRANDÃO, M.F. Efeito dos agrotóxicos no sistema auditivo de trabalhadores rurais. Rev. CIPA, jan/mar: 46-50, 1998.

TIBONI, E.B. Generalidades sobre inseticidas. Curitiba, Instituto de Tecnologia do Paraná - TECPAR, 1991.

TRIVEDI, N.; KAKKAR, R.; SRIVASTAVA, M. K.; MITHAL, A.; RAIZADA, R. B. Effect of oral administration of fungicide-mancozeb on thyroid gland of rat. Indian J. Exp. Biol., 31: 564-6, 1993.

UNGARO, M.T.S.; GUINDANI, C.M.A; FERREIRA, M.S.; BAGDONAS, M. Resultados de análises de residuos de inseticidas clorados e fosforados em frutas e hortaliças no periodo de 1978 e 1983. Biológico, 51: 239-241, 1985.

UNGARO, M.T.S.; GUINDANI, C.M.A; FERREIRA, M.S.; BAGDONAS, M. Residuos de inseticidas clorados e fosforados em frutas e hortaliças(III). Biológico, 53: 51-56, 1987. 
UNGARO, M.T.S.; PIGATI, P.; GUINDANI, C.M.A; FERREIRA, M.S.: GEBARA, A.B.; ISHIZAKI, T. Resíduos de inseticidas clorados e fosforados em frutas e hortaliças. Biológico, 19: 129-134, 1980.

UNGARO, M.T.S.; PIGATI, P.; GUINDANI, C.M.A; FERREIRA, M.S.; GEBARA, A.B.; ISHIZAKI, T. Residuos de inseticidas clorados e fosforados em frutas e hortaliças (II). Biológico, 49: 1-8, 1983.

VAN DER POLL, J. M., VERSLUIS-de HAAN, G. G., de WILDE, O. Determination of ethylenethiourea in water samples by gas chromatography with alkali flame ionization detection and mass spectrometric confirmation. J. Chromatogr., 643: 163-8, 1993.

VAN LEEUWEN, C. J.; MAAS-DIEPEVEEN, J. L.; NIEBEEK, G.; VERGOUW, W. H. A.; GRIFFIOEN, P. S.; LUIJKEN, M. W. Aquatic toxicological aspects of dithiocarbamates and related compounds. I Short-term toxicity tests. Aquat. Toxicol., 7: 145-64, 1985a.

VAN LEEUWEN, C. J.; MOBERTS, F.; NIEBEEK, G. Aquatic toxicological aspects of dithiocarbamates and related compounds. II. Effects on survival, reproduction and growth of Daphina Magna. Aquat. Toxicol. 7: $165-75,1985 b$.

VIANA, A. \& MARTINS, A. P. C. Alterações morfológicas em hepatócitos de Brachydanio rerio exposto à ação do endosulfan em dose subletal Pestic. Rev. Téc. Cient., 5: 83-94, 1995.

WALASH, M. I.; BELAL, F.; METWALLY, M. E.; HEFNAWY, M. $M$ Spectrophotometric determination of maneb, zineb and their decomposition products in some vegetables and its application to kinetic studies after greenhouse treatment. Food Chem., 47: 411-6 
1993.

WORLD HEALTH ORGANIZATION. Pesticide residue analysis. Copenhagen, 1984. (Interim Document, 14).

WORLD HEALTH ORGANIZATION. Dithiocarbamate pesticides ethylenethiourea, and propylenethiourea: a general introduction. Geneva, 1988. (WHO - Environmental Health Criteria, 78).

WORLD HEALTH ORGANIZATION. Public health impact of pesticides used in agriculture. Geneva, 1990.

YOKOMIZO, Y. Levantamento da contaminação de alimentos processados por residuos de pesticidas. Bol. ITAL, 16: 41-51, 1979.

YOKOMIZO, Y.; MANTOVANI, D.M.B.; ANGELUCCI, E.; PASQUINELLI, S.R.; DESTRO, M.T. Avaliação da contaminação de óleos e gorduras vegetais por residuos metálicos e de pesticidas. Bol. ITAL, 21: 121$276,1984 b$.

YOKOMIZO, Y.; MANTOVANI, D.M.B.; ANGELUCCI, E.; PASQUINELLI, S.R.; OLIVER, G.M.C. Avaliação da contaminação de produtos de laticinios por residuos de pesticidas e contaminantes metálicos. Bol. ITAL, 21: 469-488, 1984a.

YOSHIDA, A.; HARADA, T.; HAYASHI,S.; MORI, I.; MIYAJIMA, H.; MAITA, K. Endometrial carcinogenesis induced by concurrent oral administration of ethylenethiourea and sodium nitrite in mice. Carcinogenesis, 15: 2311-8, 1994.

YOSHIDA, A.; HARADA, T.; MAITA, K. Tumor induction by concurrent oral administration of ethylenethiourea and sodium nitrite in mice. Toxicol Pathol., 21: 303-10, 1993. 
ZAMBRone, F. A. D. Perigosa familia. Ciênc. Hoje, 4: 44-7, 1986.

ZANDONÁ, M. S.; ZAPPIA, V. R. S. Residuos de agrotóxicos em alimentos: resultado de cinco anos de monitoramento realizado pela Secretaria de Saúde do Paraná. Pest. Rev. Téc. Cient., 3: 49-95, 1993.

ZAVATTI, L. M. S. \& ABAKERLI, R. Determination of pesticide residues in tomato fruits with a multiresidue method. In: IUPAC/GARP workshop on pesticides - uses and environmental safety in Latin America, $1^{\circ}$, São Paulo, 1996. Book of Abstracts. São Paulo, IUPAC/GARP, 1996. p.78. 
zAmbrone, F. A. D. Perigosa familia. Ciênc. Hoje, 4: 44-7, 1986.

ZANDONÁ, M. S.; ZAPPIA, V. R. S. Residuos de agrotóxicos em alimentos: resultado de cinco anos de monitoramento realizado pela Secretaria de Saúde do Paraná. Pest. Rev. Téc. Cient., 3: 49-95, 1993.

ZAVATTI, L. M. S. \& ABAKERLI, R. Determination of pesticide residues in tomato fruits with a multiresidue method. In: IUPAC/GARP workshop on pesticides - uses and environmental safety in Latin America, $1^{\circ}$, São Paulo, 1996. Book of Abstracts. São Paulo, IUPAC/GARP, 1996. p.78. 


\section{9 - ANEXOS}


ANEXO 1 : Imagem digitalizada do perímetro irrigado do vale do São Francisco, obtida por satélite LANDSAT-TM 
PERÍMETRO IRRIGADO [] VALE DE SÃO FRANCISCO

PROJETO SEN IDOR NILO COELHO

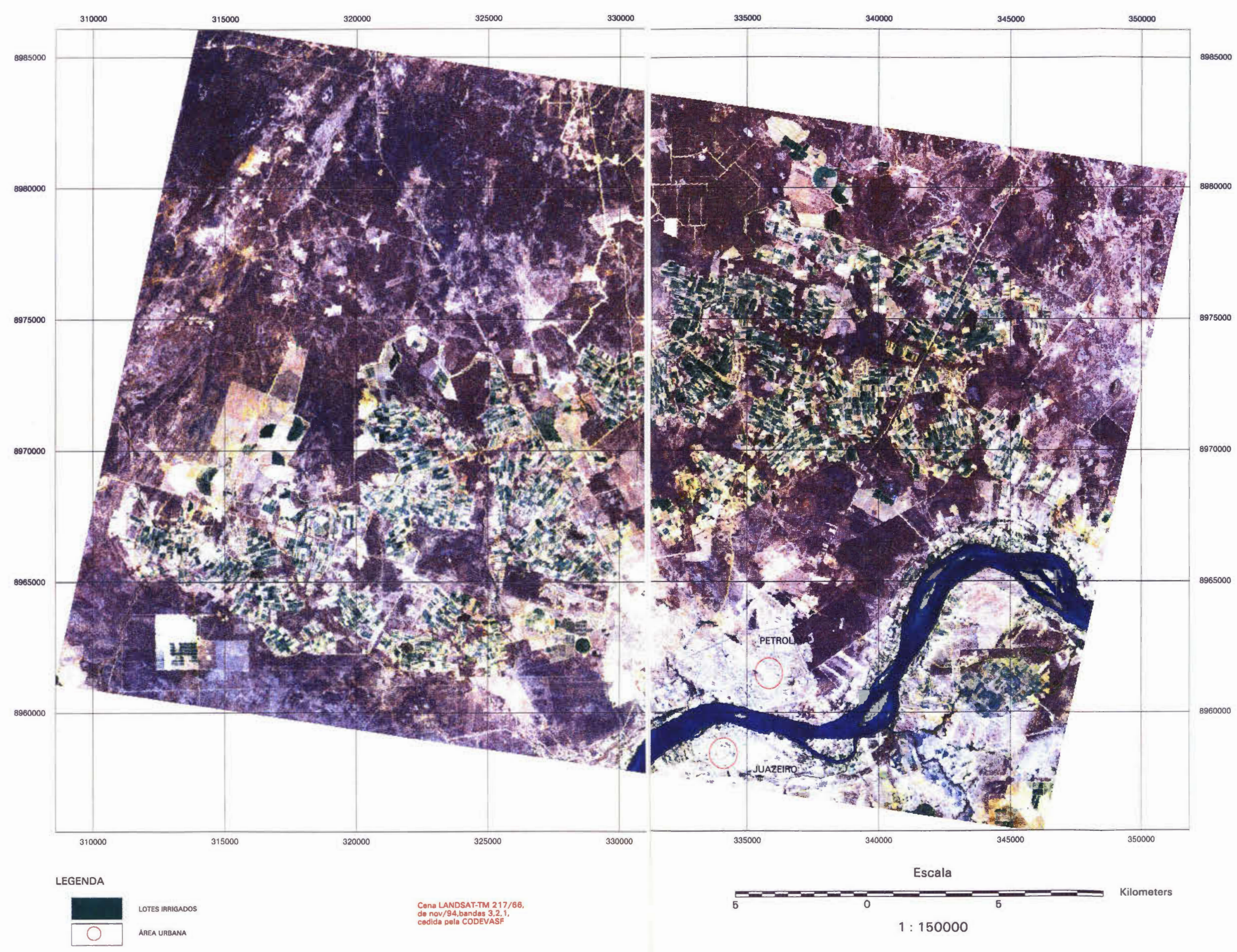


ANEXO II: Imagem digitalizada do Município de Camocim de São Félix, obtida por satélite LANDSAT-TM 
MUNICÍPIO DE CAMOCIM DE SÃO FÉLIX

LOCALIZAÇÃO APROXIMADA DAS ÁREAS DE ESTUDO COM CULTIVO DE TOMATE

CARTA IMAGEM DE LANDSAT-TM

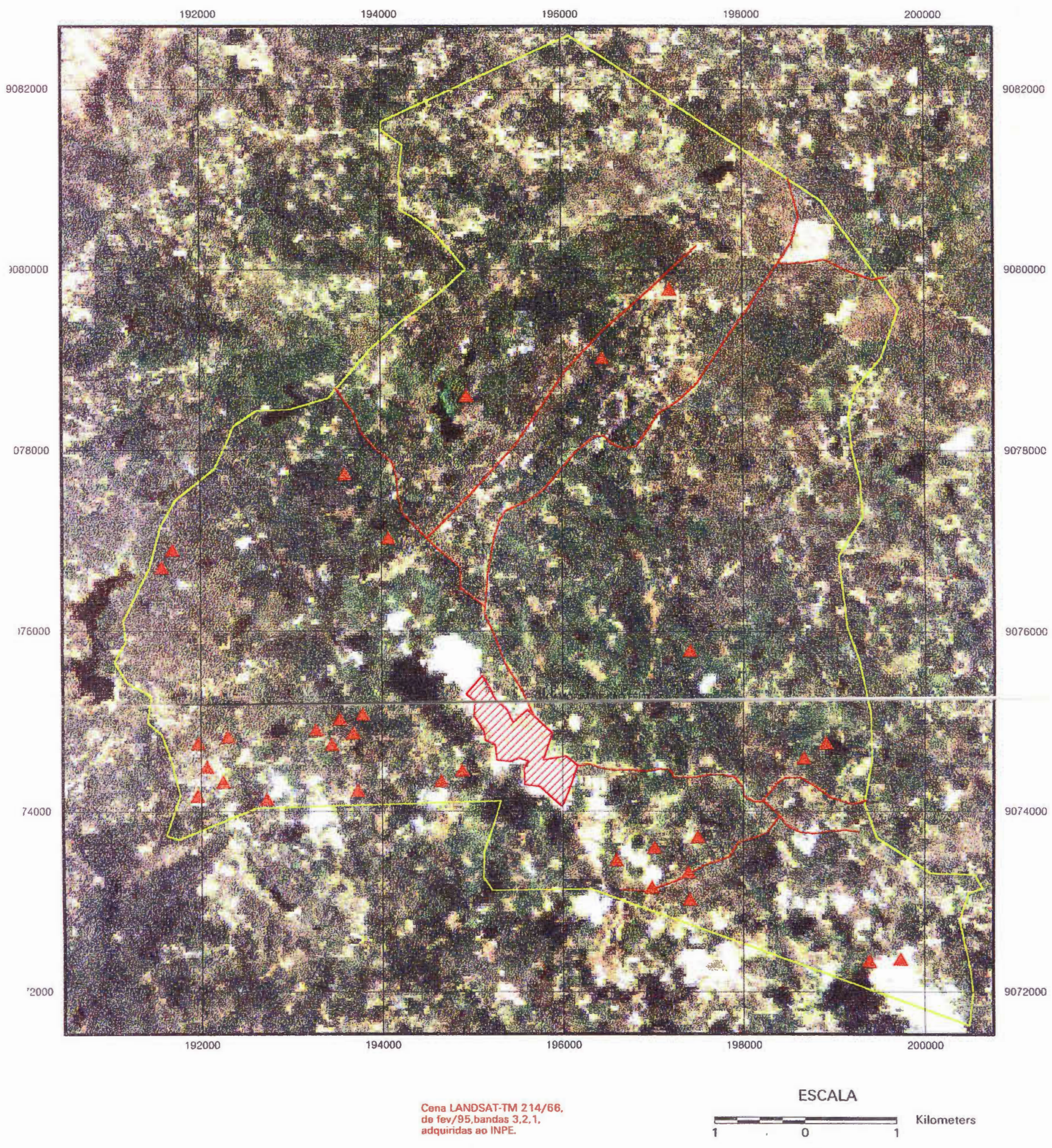

LEGENDA

$1: 50000$

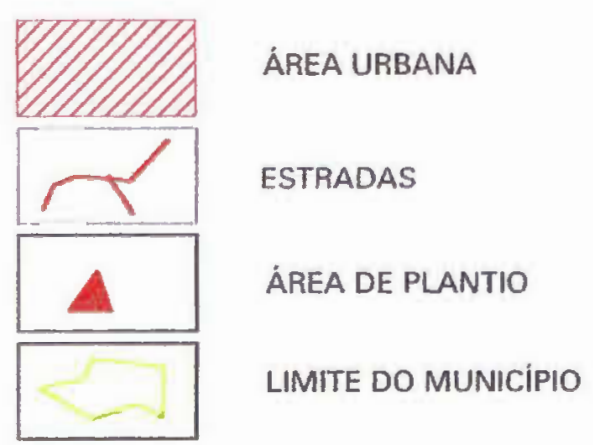


ANEXO III: Questionário aplicado em produtores de tomate industrial do Projeto Senador Nilo 
INFORMAÇŐES SOBRE A CULTURA E PRODUTOS QUIMICOS UTILIZADOS

(para ser respondido pelo proprietário do lote)

1. Identificação do local

- Núcleo: Lote:

- Responsável:

2. Dados da cultura

- Cultura anterior:

- Data do plantio:

- Data da colheita:

- Área cultivada:

\section{Aplicação dos agrotóxicos}

- Método de aplicação: pulverizaçăo costal $\square$ sim $\square$ não

$$
\text { outro: }
$$

- Equipamento de aplicação: manual $\square$ sim $\square$ não

- No processo, quantas pessoas trabalham na pulverização?

Quantas da própria familia?

Quantas contratadas?

- Medida de proteção individual

$\square \operatorname{sim} \quad \square$ não

Qual?

- Destino do material utilizado (frascos, vidros, caixas)

4. Irrigação

-Tipo de irrigação: aspersão

$\square \operatorname{sim} \quad \square$ não

sulcos $\square \operatorname{sim} \square$ não

- Quantas irrigação por semana?

- Quanto tempo por irrigação? 
INFORMAÇŌES SOBRE O USO DE AGROTÓXICOS

(para ser respondido pelo aplicador de agrotóxico)

- Identificação

- Aplicador de agrotóxico

- Núcleo Lote

- Tempo de trabalho com agrotóxicos

- Medidas de proteção individual
$\operatorname{sim}$
$\square$ não

Quais?

- Exame de saúde periódico

$\square \operatorname{sim}$

$\square$ não

Onde

- Já teve algum problema de saúde pela exposição a agrotóxicos

$\square \operatorname{sim} \square$ não

Há quanto tempo?

Quantas vezes?

Precisou de atendimento médico?

$\square \operatorname{sim}$

$\square$ não

Precisou ser internado?

$\square \operatorname{sim}$

$\square$ não

As ocorrências foram registradas como acidente de trabalho?

$\square \operatorname{sim} \quad \square$ não

- Já sofreu algum acidente de trabalho? $\square$ sim $\square$ não

Foi registrado? $\square \operatorname{sim} \square$ năo

Onde foi atendido?

- Sente algum incômodo ou dor constante?

$\square \operatorname{sim} \quad \square$ não

Qual?

Toma algum remédio?

$\square \operatorname{sim} \quad \square$ não

Por quê? 
- Como a calda é preparada?

- Destino do material utilizado (frascos, vidros, caixas, etc)

- Calendário das aplicaçōes

Data: Produto quimico:

Quantidade: Tipo de formulação

Data: Produto quimico:

Quantidade: Tipo de formulação

Data: Produto químico:

Quantidade: Tipo de formulaçăo

Data: Produto químico:

Quantidade: Tipo de formulação

Data: Produto químico:

Quantidade: Tipo de formulaçăo

Data: Produto quimico:

Quantidade: Tipo de formulaçăo 
ANEXO IV: Questionário aplicado em produtores de ton de mesa do Município de Camocim de São Félix 
LEVANTAMENTO DE MORBIDADE OCUPACIONAL RELACIONADA AO USO AGROTOXICOS NA CULTURA DE TOMATE

Nome do entrevistador:

Data:

Municipio: No

I - Processo de Produção: (produtor)
a - Data do plantio:
1
b - Data da colheita:
c - Irrigaçāo:
$\square \operatorname{sim}$
$\square$ nảo
d - Freqüência:

e -Tipo:

f - Insumos utilizados na produção 


\section{II - Identificação Geral do entrevistado (trabalhador)}

1 - Nome

2 - Data de nascimento: Idade (em anos):

3 - Endereço atual:

4 - Municipio de origem: Estado:

5- Sexo: $\square$ fem

7 mas

6 - Estado civil: $\square$ solteiro

$\square$ casado

$\square$ separado

$\square$ viúvo

7 - Até que ano vocẽ estudou?

$\square$ analfabeto

$\square$ primário incompleto

$\square$ primário completo

$\square$ secundário incompleto

$\square$ secundário completo

$\square$ outro

III - Condições gerais de vida:

8 - Local de moradia: $\quad \square$ na cidade

no campo 
9 - Os alimentos consumidos pela familia são comprados?

$\square \operatorname{sim} \quad \square$ nảo

Quais?

10 - São produzidos para autoconsumo? $\square$ sim $\square$ não

Quais?

11 - No de pessoas por dormitório:

12 - Água consumida $\square$ açude

$\square$ bica

$\square$ caminhão pipa

$\square$ tratada

$\square$ poço

$\square$ rio

13 - Na residência tem privada? $\square$ sim $\square$ não

14 - No municipio o esgoto vai para: $\square$ rede

$\square$ fossa séptica

fossa negra

$\square$ rua/vala

15 - Principal divertimento (lazer):

IV - Relações de Trabalho

16 - Qual é o local de trabalho?

17 - Qua é sua função (o que faz?) 
18 - Há quanto tempo trabalha nessa função?

19 - Como é seu contrato de trabalho?

$$
\begin{aligned}
& \square \text { assalariado } \\
& \square \text { meeiro } \\
& \square \text { diarista } \\
& \square \text { autônomo } \\
& \square \text { por produção } \\
& \square \text { outro }
\end{aligned}
$$

20 - Há quanto tempo é lavrador?

21 - Quais as plantaçōes em que trabalhou nos últimos dois anos?

22 - Onde trabalhou nestes últimos dois anos?

23 - Contando com o senhor(a) quantos são os membros da família?

24 - Número de filhos:

25 - Idade dos filhos em anos: homens mulheres

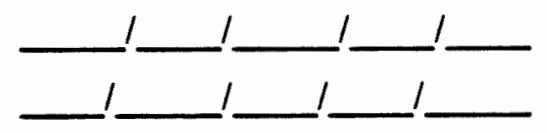

26 - Quantos membros da familia trabalham na lavoura?

27 - Quais filhos trabalham na lavoura, indicar por idade:

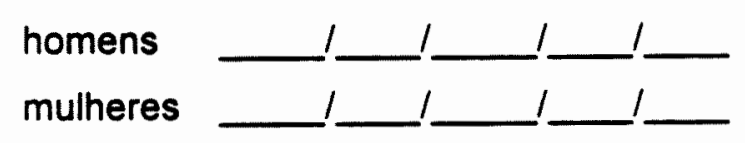

28 - Em caso de homem, se a mulher trabalha na lavoura?

29 - Quantos membros da familia trabalham juntos? homens:

mulheres:

30 - Horário de trabalho: início: término: 
31 - Descanso semanal: $\square$ sim $\square$ não

32 - Quanto você recebe/mês?

33 - Qual é a renda familiar total (contando salário, aposentadorias, pensão, outras)?

34 - Qual é forma de pagamento?

35 - Quanto tempo gasta desde sua casa até chegar no trabalho?

36 - Qual é o meio de transporte para ir trabalhar?

37 - É fornecido pelo contratante ? $\square$ sim $\square$ não

38 - Tem carteira assinada? $\square$ sim $\square$ nāo

39 - Paga Previdência Social? $\square$ sim $\square$ não

40 - E filiado ao sindicato dos trabalhadores rurais?

$\square \operatorname{sim} \quad \square$ não

41 - Quais são os instrumentos utilizados no trabalho?

42 - São fornecidos pelo contratante $\quad \square \quad \square$ são própios 


\section{V - Dados epidemiológicos de contato com produtos agrícolas}

43 - Produtos químicos que utiliza na cultura do tomate:

Preparo da terra:

Na sementeira:

Durante a cultura:

Na colheita:

44 - Compra dos produtos: $\square$ representante

$\square$ comércio local

$\square$ outros municipios

$\square$ cooperativa

$\square$ fornecido pelo contratante

$\square$ outros

45 - Orientação de uso: $\square$ sem orientação

$\square$ profissional técnico

$\square$ vendedor

$\square$ contratante

$\square$ outros:

46 - Como prepara a calda?

47 - Utilizaçảo do receituário agronômico: $\square$ sim

$\square$ não

$\square$ ignorado

48 - Forma de aplicação 
49 - Obedece tempo de carência após última aplicação antes da colheita?

$\square$ sim
$\square$ não
$\square$ ignorado

50 - Utiliza equipamentos de proteção individual?

$$
\begin{aligned}
& \square \text { sim } \\
& \square \text { não }
\end{aligned}
$$

Quais?

51 - Observa a direção do vento durante aplicação do veneno?

$$
\begin{aligned}
& \square \text { sim } \\
& \square \text { não }
\end{aligned}
$$

52 - Destino das embalagens vazias:

$$
\begin{aligned}
& \square \text { vendida } \\
& \square \text { deixada no campo } \\
& \square \text { reaproveitada } \\
& \square \text { depósito de lixo comum } \\
& \square \text { depósito de lixo tóxico } \\
& \square \text { queimada } \\
& \square \text { enterrada } \\
& \square \text { devolvida ao comerciante } \\
& \square \text { tripla lavagem } \\
& \square \text { outra }
\end{aligned}
$$

53 - Lavagem dos equipamentos de aplicação: $\square$ local próprio

$$
\begin{aligned}
& \square \text { rio/lago/açude } \\
& \square \text { no campo } \\
& \square \text { na lavoura } \\
& \square \text { outro }
\end{aligned}
$$

54 - Quem lava sua roupa de trabalho?

Onde? 


\section{VI - Dados epidemiológicos de antecedentes mórbidos}

55 - Já sofreu algum tipo de intoxicação por veneno utilizado na lavoura?

$$
\square \operatorname{sim}
$$

$\square$ não

Há quanto tempo?

56 - Quantas vezes já sofreu intoxicaçāo?
57 - Teve socorro médico?
$\square \operatorname{sim}$
$\square$ não

Onde?

Qual tratamento?

58 - Sente algum mal estar quando aplica veneno?

$\square \operatorname{sim}$

$\square$ não

Quanto tempo depois?

59 - Aponte as queixas de saúde:

a. 1 - Tem dores de cabeça frequentes?

$\square \operatorname{sim} \quad \square$ não

a.2 - Tem falta de apetite?

$\square \operatorname{sim} \quad \square$ nảo

a.3 - Dorme mal?

$\square \operatorname{sim} \quad \square$ não

a.4 - Assusta-se com facilidade?

$\square \operatorname{sim}$

$\square$ não

a.5 - Tem tremores na mão?

$\square \operatorname{sim}$

$\square$ não

a.6 -Sente-se nervoso(a), tenso(a) ou preocupado

$\square \operatorname{sim}$

$\square$ não

a.7 - Tem má digestão?

$\square \operatorname{sim}$

$\square$ não

a.8 - Tem dificuldade para pensar com clareza

$\square \operatorname{sim}$

$\square$ não

a. 9 - Tem se sentido triste ultimamente

$\square \operatorname{sim}$

$\square$ não

a.10 - Tem chorado mais do que de costume

$\square \operatorname{sim}$

$\square$ nảo

a.11 - Encontra dificuldades para realizar com satisfação as suas atividades diárias
a.12 - Tem dificuldade para tomar decisões
$\square \operatorname{sim}$
$\square$ não
$\square \operatorname{sim}$
$\square$ não

a.13 - Tem dificuldades no serviço (seu trabalho é penoso, causa-lhe sofrimento)

$\square \operatorname{sim} \quad \square$ não


a.14 - Sente-se incapaz de desempenhar um papel útil em sua vida?

$\begin{array}{lll}\text { a.15 - Tem perdido o interesse pelas coisas? } & \square \operatorname{sim} & \square \text { não } \\ \text { a.16 - Você se sente uma pessoa inútil sem préstimo? } & \square \operatorname{sim} & \square \text { não } \\ \text { a.17 - Tem tido a idéia de acabar com a vida? } & \square \text { sim } & \square \text { não } \\ \text { a.18 - Sente-se cansado(a) o tempo todo? } & \square \text { sim } & \square \text { não } \\ \text { a.19 - Tem sensaçōes desagradáveis no estômago? } & \square \operatorname{sim} & \square \text { não } \\ \text { a.20 - Você se cansa com facilidade? } & \square \operatorname{sim} & \square \text { não }\end{array}$

b. 1 - Sente-se chateado(a) com sigo mesmo(a) pela maneira com que costuma beber?

$\square \operatorname{sim} \quad \square$ năo

b. 2 - Costuma beber pela manhả para diminuir o nervosismo ou ressaca?

$\square \operatorname{sim} \quad \square$ não

b. 3 - As pessoas o (a) aborrecem porque criticam o seu modo de beber?

$\square \operatorname{sim} \quad \square$ não

b.4 - Alguma vez sentiu que deveria diminuir a quantidade de bebida ou parar de beber?

$\square \operatorname{sim} \quad \square$ não

c.1 - Sente tontura?

$\begin{array}{ll}\square \text { sim } & \square \text { não } \\ \square \text { sim } & \square \text { não } \\ \square \text { sim } & \square \text { não } \\ \square \text { sim } & \square \text { não } \\ \square \text { sim } & \square \text { não } \\ \square \text { sim } & \square \text { não } \\ \square \text { sim } & \square \text { não } \\ \square \text { sim } & \square \text { não } \\ \square \text { sim } & \square \text { não } \\ \square \text { sim } & \square \text { não } \\ \square \text { sim } & \square \text { não } \\ \square \text { sim } & \square \text { não } \\ \square \operatorname{sim} & \square \text { não } \\ \square \operatorname{sim} & \square \text { não } \\ \square \operatorname{sim} & \square \text { não } \\ \square \operatorname{sim} & \square \text { não } \\ \square \operatorname{sim} & \square \text { não }\end{array}$


c. 18 - Tem falta de ar quando faz esforço?

$\square \operatorname{sim}$ não

c. 19 - Tem dor no peito?

$\square \operatorname{sim}$

$\square$ não

c. 20 - tem batedeira no coração?

$\square \operatorname{sim}$

$\square$ não

c.21 - Tem pressão alta?

$\square \operatorname{sim}$

$\square$ näo

c. 21 - Tem urina escura?

$\square \operatorname{sim}$

$\square$ não

c.22 - Tem problemas sexuais (impotência/pouca vontade)?

$\operatorname{sim}$ não

c. 23 - outros:

60 - A que o sr. (a) atribui seus problemas de saúde? (por que fica doente?)

61 - O seu trabalho pode Ihe trazer problemas de saúde?

Quais?

Como (Por que)?

62 - Está tomando algum remédio?

$\square \operatorname{sim}$

não

Porquê?

Qual?

Quem receitou? 
63 - Você conhece alguém que sofreu intoxicação pelo veneno?

$\square \operatorname{sim} \quad \square$ não

64 - Como esta pessoa está de saúde?

65 - O que você faz para se proteger do veneno?
66 - É fumante?
$\square \operatorname{sim}$
$\square$ não

Que tipo?

Quantos por dia?

\section{VII - Em caso de mulher:}

67 - Número de vezes que ficou grávida:

68 - Número de filhos vivos:

69 - Teve algum filho que morreu antes de nascer? $\square$ sim $\square$ não Quantos?

Por

quê?

De qual (quais) gravidez?

70 - Teve algum filho que morreu antes do primeiro ano de vida?

Porquê? $\square$ sim $\square$ não

De qual gravidez?

71 - Teve algum filho nascido fora de tempo?

$\operatorname{sim}$ não

Quantos?

De qual (quais) gravidez?

72 -Teve algum filho nascido com baixo peso?

$\operatorname{sim}$ não

Quantos? 
De qual gravidez?

73 - Tem algum filho com defeito físico ou mental? $\square$ sim $\quad \square$ não Que tipo?

De qual gravidez?

74 - Sofreu algum tipo de intoxicação por agrotóxico durante periodo da gravidez?

$\square$ sim
$\square$ não
$\square$ não sabe

De qual (quais) gravidez? (numere)
75 - Fez acompanhamento pré-natal?
sim
$\square$ não

De que gravidez? ( numere)

OBSERVAÇŐES GERAIS DO ENTREVISTADOR: 


\section{ALGUMAS CONSIDERAÇŐES SOBRE O QUESTIONÁRIO (INSTRUMENTO DE COLETA DE DADOS):}

1 - Identificação da cultura a ser informado pelo produtor

2 - Dados sócio-demográficos dos trabalhadores/condiçōes de vida

3 - Relaçōes de trabalho/processo de trabalho

4 - Dados epidemiológicos de contato com o agroquímicos na produção

5 - Dados epidemiológicos de morbidade

6 - Em caso de mulheres, dados reprodutivos 